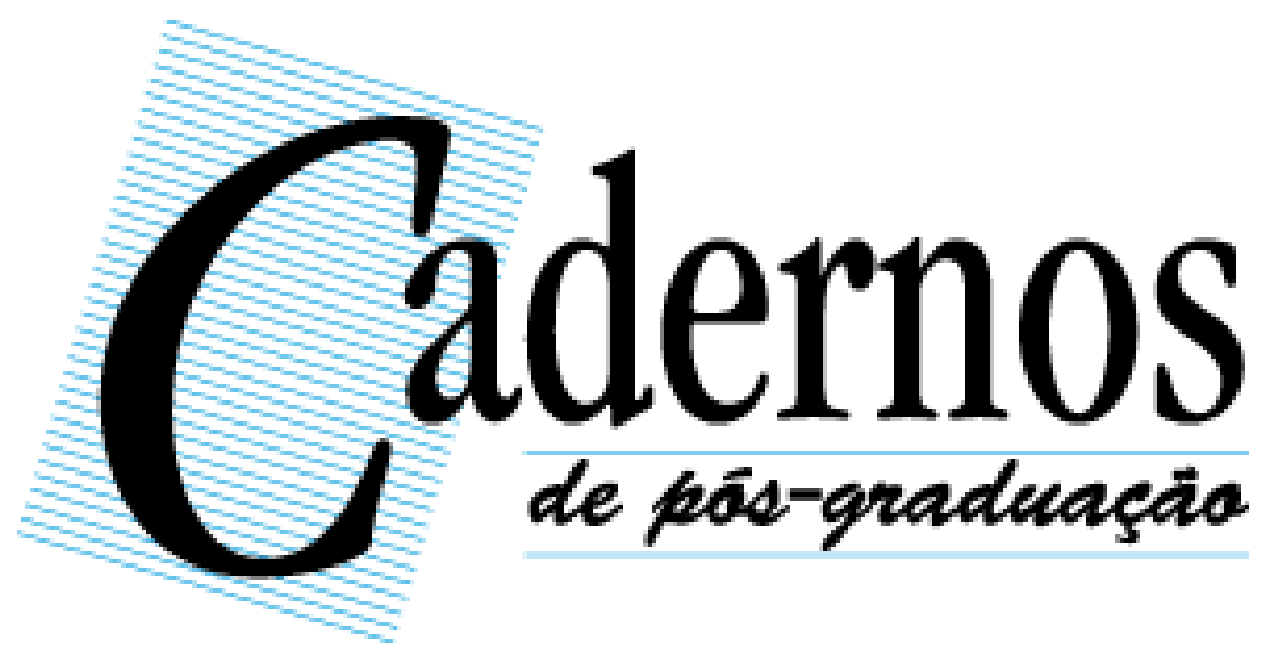

UNINOVE

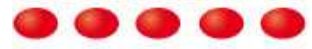

Universidade Nove de Julho

www.uninove.br

ISSN da versão online: 2525-3514

www.cadernosdepos.org.br

v. 17, n. 2

p. $1-288$

jul./dez. 2018 


\section{Cadernos \\ de pád-qraduaçãa.}

www.uninove.br/revistacadernoseduc

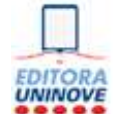

Editora Uninove

Campus Vergueiro

+55 $113385-9191$

www.uninove.br

\section{Expediente}

Revista Cadernos de Pós-graduação

Universidade Nove de Julho (UNINOVE)

Rua Vergueiro n ${ }^{\circ} 235 / 249,12^{\circ}$ andar - Liberdade, São

Paulo, SP, Brasil, CEP 01504-001.

Telefone: +55 (11) 3385-9191

Cadernos de Pós-graduação

ISSN da versão online: 2525-3514

www.cadernosdepos.org.br

\section{Editores}

Profa. Dra. Ligia de Carvalho Abões Vercelli -

Universidade Nove de Julho

E-mail de contato:

ligia@uni9.pro.br

Prof. Dr. Carlos Bauer - Universidade Nove de Julho

E-mail de contato:

carlosbauer@uni9.pro.br

\section{Afiliada}

ABEC - Associação Brasileira de Editores Científicos.

\section{Membro}

Fepae - Fórum dos Editores de Periódicos da Área da Educação.

\section{Bases indexadoras}

BASE - Bielefeld Academic Search Engine.

Diadorim - Diretório de Políticas de

Acesso Aberto das Revistas Científicas

Brasileiras.

FLACSO - Facultad Latinoamericana de

Ciencias Sociale

Livre - Periódicos de livre acesso.

Sumários de Revistas Brasileiras.

\section{Certificação Qualis}

Qualis Periódicos.

B4 - Educação
(C) 2018 - Universidade Nove de Julho (Uninove)

\section{Reitoria}

Eduardo Storópoli

\section{Pró-reitoria Acadêmica}

Maria Cristina B. Storópoli

\section{Pró-reitoria Administrativa}

Jean Anastase Tzortzis

Pró-reitorias de campus

Claudio Ramacciotti

Renato Rodrigues Sofia

Diretoria do Programa de Pós-Graduação em Educação (PPGE)

José Eustáquio Romão

Diretoria do Programa de Mestrado em Gestão e Práticas Educacionais (PROGEPE)

Jason Mafra

\section{Diretoria de Pesquisa}

João Carlos Ferrari Corrêa

\section{Equipe Editorial}

Juliana Cezario

Cristiane dos Santos Monteiro 


\section{Comissão Editorial}

Ana Maria Haddad Baptista,

Universidade Nove de Julho - Brasil

Carlos Bauer, Universidade Nove de

Julho - Brasil

Celso do Prado Ferraz de Carvalho,

Universidade Nove de Julho - Brasil

Jason Ferreira Mafra, Universidade Nove

de Julho - Brasil

\section{Conselho Editorial}

Adrián Ascolani - IRICE-CONICET

[Argentina]

Álvaro Acevedo Tarazona - UDES

[Colômbia]

Amarílio Ferreira Junior - UFSCar [Brasil]

André Paulo Castanha - UNIOESTE

[Brasil]

Andre Robert - Université Lyon2 [França]

Antonio Ozaí da Silva - UEM [Brasil]

Cristian Fernando Gajardo Díaz - PIIE

[Chile]

Danilo Streck - UNISINOS [Brasil]

Dante Castillo - PIIE [Chile]

Danusa Mendes Alimeida - UECE

[Brasil]

Deise Mancebo - UERJ [Brasil]

Edgar Pereira Coelho - UFV [Brasil]

Evaldo Amaro Vieira - USP [Brasil]

Eveline Algebaile - UERJ [Brasil]
José Eustáquio Romão, Universidade

Nove de Julho - Brasil

Ligia de Carvalho Abões Vercelli,

Universidade Nove de Julho - Brasil

Marcos Antônio Lorieri, Universidade

Nove de Julho - Brasil

Rosemary Roggero, Universidade Nove

de Julho - Brasil

Everaldo Andrade - USP [Brasil]

Heidi Soraia Berg - UFAC [Brasil]

João do Prado - Unifesp [Brasil]

José Rubens Lima Jardilino - UFOP

[Brasil]

Julián Gindin - UFF [Brasil]

Kate Rousmaniere - Miami University

[EUA]

Luciana Pacheco Marques - UFJF [Brasil]

Marcos Francisco Martins -

UFSCar/Sorocaba [Brasil]

Maria Beatriz Moreira Luce - UFRGS

[Brasil]

Marisa Bittar - UFSCar [Brasil]

Nima I. Spigolon - Unicamp [Brasil]

Oscar Espinoza - [Chile]

Raymond Morrow - UAlberta [Canadá]

Silvia Maria Manfredi - IPF [Brasil]

Silvio Gallo - Unicamp [Brasil 


\section{Pareceristas Ad hoc - 2018}

Ana Maria Haddad Baptista - Universidade

Nove de Julho

Antonia Edna Brito - Universidade Federal do

Piauí

Carlos Bauer - Universidade Nove de Julho

Celia Maria Haas - Universidade Cidade de São

Paulo

Celso do Prado Ferraz de Carvalho -

Universidade Nove de Julho

Daniela Costa Britto Pereira Lima -

Universidade Federal de Goiás

Dirceu Benincá - Universidade Federal do Sul da

Bahia

Elizete Lanzoni Alves - Secretaria de Ensino

Superior - SESu/MEC

Fatima Aparecida de Souza - Universidade de Sorocaba

Gustavo Cunha Araújo - Universidade Federal do Tocantins

Hergos Ritor Froes de Couto -Universidade

Federal do Oeste do Pará

Jorge Luiz da Cunha - Universidade Federal de

Santa Maria

Jorge Luis Cammarano González -

Universidade de Sorocaba

José Eustáquio Romão - Universidade Nove de Julho
Ligia de Carvalho Abões Vercelli - Universidade Nove de Julho

Luciene Barbosa Vitor Lima - Universidade Federal da Grande Dourados

Lucilene Schunck Costa Pisanechi -

Universidade Nove de Julho

Manuel Tavares - Universidade Nove de Julho

Márcia Fusaro - Universidade Nove de Julho

Marcos Antônio Lorieri - Universidade Nove de

Julho

Maria Rita Aprile - Fundação Carlos Chagas

Maria Edith Romano Siems Marcondes -

Universidade Federal de Roraima

Maurício Pedro da Silva - Universidade Nove de Julho

Natalino Neves da Silva - Universidade Federal de Alfenas

Régia Vidal Santos - Universidade Nove de Julho

Regina Magna Bonifácio de Araujo Universidade Federal de Ouro Preto

Roberta Stangherlim - Universidade Federal de São Paulo

Rosemary Roggero - Universidade Nove de Julho

Rosiley Aparecida Teixeira - Universidade Nove de Julho

Sonia Maria Ribeiro - Universidade da Região de Joinville

Cadernos de pós-graduação é uma publicação acadêmica, do Programa de Pós-graduação em Educação (PPGE) e do Programa de Mestrado em Gestão e Práticas Educacionais (PROGEPE), da Universidade Nove de Julho (Uninove), de acesso aberto e gratuito. Cadernos se propõe a divulgar estudos e resultados de pesquisas pertinentes às questões educacionais de forma ampla e em diálogo com as demais áreas humanas e sociais, realizadas por 
alunos e professores, desenvolvidos nos programas de pós-graduação stricto sensu nacionais, estrangeiros e de outras organizações preocupadas com a produção do conhecimento científico.

Cadernos de Pós-graduação está avaliada pelo QUALIS-CAPES como B4.

\section{REPRODUÇÃO AUTORIZADA, DESDE QUE CITADA A FONTE}

A instituição ou qualquer dos organismos editoriais desta publicação não se responsabilizam pelas opiniões, ideias e conceitos emitidos nos textos, de inteira responsabilidade de seu(s) autor(es).

\section{SuMÁRIO / CONTENTS}

\section{EDITORIAL / EDITOR'S NOTE}

A EDUCAÇÃO ESCOLAR QUILOMBOLA, EDUCAÇÃO DAS RELAÇÕES ÉTNICO-RACIAIS E PARA O ENSINO DE HISTÓRIA E CULTURA AFRO-BRASILEIRA E AFRICANA E A IMPORTÂNCIA DE SUA PRESENÇA NA BASE NACIONAL COMUM CURRICULAR (BNCC).

THE QUILOMBOLA SCHOOL EDUCATION, ETHNIC AND RACIAL RELATIONS EDUCATION AND FOR THE TEACHING OF AFRO-BRAZILIAN AND AFRICAN HISTORY AND CULTURE AND THE IMPORTANCE OF ITS PRESENCE IN THE NATIONAL CURRICULAR COMMON BASE (BNCC)

Carlos Bauer

Ligia de Carvalho Abões Vercelli

DOSSIÊ TEMÁTICO: EDUCAÇÃO ESCOLAR QUILOMBOLA, EDUCAÇÃO DAS RELAÇÕES ÉTNICO-RACIAIS E PARA O ENSINO DE HISTÓRIA E CULTURA AFROBRASILEIRA E AFRICANA

THEMATIC DOSSIER: QUILOMBOLA SCHOOL EDUCATION, EDUCATION OF ETHNICRACIAL RELATIONS AND FOR THE AFRO-BRAZILIAN AND AFRICAN HISTORY AND CULTURE TEACHING

EDUCAÇÃO DO CORPO E RELAÇÕES ÉTNICO-RACIAIS SOB O OLHAR DE PROFESSORES. $.15-33$

EDUCATION OF BODY AND ETHNIC-RACIAL RELATIONS UNDER THE GAZE OF

TEACHERS

Kalyla Maroun

A IDENTIDADE QUILOMBOLA E EDUCAÇÃO ESCOLAR QUILOBO-LA: CONTRIBUIÇÕES A PARTIR DA EXPERIÊNCIA DE UM QUILOMBO.

QUILOMBOLA IDENTITY AND QUILOMBOLA SCHOOL EDUC-TION: CONTRIBUTIONS FROM THE EXPERIENCE OF A QUILOMBO

Sandra Nivia Soares de Oliveira

CURRÍCULO MULTICULTURAL COMO INSTRUMENTO DE EMPODERAMENTO DE ESCOLAS

QUILOMBOLAS. $.55-74$ MULTICULTURAL CURRICULUM AS AN INSTRUMENT FOR THE EMPOWERMENT OF MAROON SCHOOLS 
A FORMAÇÃO DOCENTE CONTINUADA PARA AS RELAÇÕES ÉTNICO-RACIAIS NO RIO DE JANEIRO: A EXPERIÊNCIA DO PROGRAMA DE ESTUDO SOBRE O NEGRO NA SOCIEDADE BRASILEIRA (PENESB/UFF). 75-97

THE CONTINUED TEACHING TRAINING FOR ETHNIC-RACIAL RELATIONS IN RIO DE JANEIRO: THE EXPERIENCE OF THE PENESB / UFF COURSE

Vitor Leandro de Souza

Tiago Dionísio da Silva

Tatiane Pacheco de Mattos

OS SABERES E FAZERES DAS CRIANÇAS QUILOMBOLAS MARAJOARA-SALVATERRAPARÁ

THE KNOWLEDGES AND PRACTICES OF QUILOMBOLA MARAJOARA CHILDREN -

SALVATERRA - PARÁ

Erica de Sousa Peres

Nazaré Cristina Carvalho

A LEI 10.639/03 E AS RELAÇÕES ÉTNICO-RACIAIS NO AMBIENTE ESCOLAR: MUDANÇAS E PERMANÊNCIAS. ..121-140

LAW 10.639/03 AND THE ETHNIC-RACIAL RELATIONS IN THE SCHOOL ENVIRONMENT:

CHANGES AND STAYS

Nivea Maria Araújo Santana

\section{ARTIGo/ ARTICLE}

FORMAÇÃO DE EDUCADORES E A EDUCAÇÃO INCLUSIVA: DA SENSIBILIDADE ÉTICOPOLÍTICA À CONDIÇÃO HUMANA. $143-166$

EDUCATION TRAINING AND INCLUSIVE EDUCATION:

FROM ETHICAL-POLITICAL SENSITIVITY TO HUMAN CONDITION

Marisa Soares

DESAFIOS E SURPRESAS DA INCLUSÃO DE UMA CRIANÇA CEGA EM SALA DE AULA. $. .167-182$

CHALLENGES AND SURPRISES OF THE INCLUSION OF A BLIND CHILD IN A CLASSROOM

Valquiria Bertuzį Veronesi

Francisca Eleodora Santos Severino

EDUCAÇÃO, COMUNICAÇÃO E MÍDIA: UMA ABORDAGEM TEÓRICA $.183-196$

EDUCATION, COMMUNICATION AND MEDIA: A THEORETICAL APPROACH

Douglas Branco de Camargo

Iris Weiduschat

Alvin Noriler

POLÍTICAS DE EDUCAÇÃO ESPECIAL: ANÁLISE DO PLANO DE EDU-CAÇÃO (2015 - 2025) E

DIRETRIZES DA EDUCAÇÃO ESPECIAL (2012) DE MACAPÁ-AP.... $197-221$ 
SPECIAL EDUCATION POLICIES: ANALYSIS OF THE EDUCATION PLAN AND GUIDELINES FOR MACAPÁ-AP SPECIAL EDUCATION

Marcia Maria dos Santos

Maria do Carmo Lobato da Silva

Ilma de Andrade Barleta

POLÍTICAS DE INCLUSÃO E A REALIDADE PROFISSIONAL: A EXPERIÊNCIA DE UMA GRADUANDA CEGA NO ESTÁGIO CURRICULAR SUPERVISIONADO

INCLUSION POLICIES AND THE PROFESSIONAL REALITY: THE EXPERIENCE OF A BLIND GRADUATE IN THE SUPERVISED CURRICULAR INTERNSHIP

Kalina Salaib Springer

Sabrina Mangrich de Assunção

Yanna D'Angelis de Carvalho Gonçalves

EDUCAÇÃO INCLUSIVA, OS DESAFIOS PARA SUA EFETIVAÇÃO. $.239-249$

INCLUSIVE EDUCATION, THE CHALLENGES FOR THEIR

EFFECTIVENESS

Carla Campos de Oliveira Almeida

\section{RESENHAS / REVIEWS}

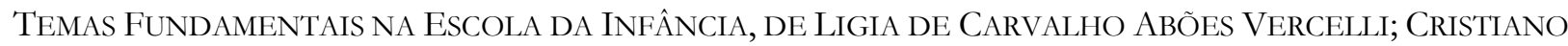
ROGÉRIO ALCÂNTARA (ORG) $251-257$

Simone Eliane dos Santos Pessanba

Plano Nacional de EducaÇÃo: Diversos olHares, de Andréia Nunes Militão e Fabio PERBONI $.259-262$

Sueli do Nascimento

Welcianne Iris de Queiroz.

A EDUCAÇÃO BÁSICA PÚBLICA TEM SOLUÇÃO? DE HERMAN J.C. VOORWALD. $263-267$

Carlos Lima Dantas

A VIDA COTIDIANA DOS ADOLESCENTES EM CONFLITO COM A LEI E O ENVOLVIMENTO COM PRÁTICAS DELITIVAS, DE Neusa Francisca DE JESUS $.269-273$

Agnaldo Aparecido Geremias

FORMAÇÃO INICIAL DE PROFESSORES: DA ESCOLA NORMAL AO INSTITUTO SUPERIOR DE EDUCAÇÃO - UMA ABORDAGEM HISTÓRICA, DE LUCILENE PISANESCHI. $.275-281$

Raquel Silva Santos

\section{INSTRUÇÃO PARA AUTORES / INSTRUTIONS FOR AUTHORS}

DIRETRIZES PARA

AUTORES 


\section{Editorial}

Editor's note 


\section{A EducaÇão Escolar Quilombola, EducaÇão das RelaÇões ÉtNico-Raciais E PARA o ENSINo de História e Cultura Afro- BRASILEIRA E AFRICANA E A IMPORTÂNCIA DE SUA PRESENÇA NA Base Nacional Comum Curricular (BNCC)}

The Quilomibola School Education, EThnic and Racial Relations Education AND fOr the Teaching OF AFroBraZilian AND AFrican History AND Culture AND THE IMPORTANCE OF ITS PRESENCE IN THE NATIONAL CURRICULAR COMMON BASE (BNCC)

Stabelecer uma relação permanente, sólida e fecunda entre a educação posto para todos que se preocupam com os rumos da educação em nosso país e o seu papel na afirmação nos direitos humanos e sociais e na consolidação dos valores mais caros à edificação da civilização brasileira.

Ocorre que os problemas se multiplicam, as verbas são insuficientes, quando não, diminuem, e as diferentes etapas de ensino têm sofrido consequências, a saber: a educação infantil malogra em atender os interesses mais elementares da população por vagas nas escolas; o ensino fundamental assiste a escalada dos índices de abandono e a evasão de matrículas, o ensino médio encontra-se mergulhado num pântano 


\section{Cadernos}

A EDUCAÇ̃̃O ESCOLAR QUILOMBOLA, EDUCAÇ̃̃O DAS RELAÇÕES ÉTNICORACIAIS E PARA O ENSINO DE HISTÓRIA E CULTURA AFRO-BRASILEIRA E AFRICANA E A IMPORTÂNCIA DE SUA PRESENÇA NA BASE NACIONAL COMUM CURRICULAR (BNCC)

sombrio e os cursos universitários oferecem padrões duvidosos de qualidade na formação humana e profissional.

Não bastasse esse preocupante cenário, a maioria dos jovens se veem desestimulados e não se interessam em cursar as diferentes licenciaturas, responsáveis pela formação de professores.

Vivemos tempos difíceis no campo educacional e o escasso interesse pela profissão docente faz com que aqueles dedicados ao magistério tenham que se desdobrar na cotidianidade de suas atividades na escola, muitas vezes desassistidos das condições mais elementares para o seu pleno e efetivo exercício da docência e do fortalecimento das relações do processo ensino e aprendizagem.

Não deixa de ser inquietante e até mesmo assustador que essa verdadeira tragédia não seja capaz de comover as autoridades estatais no oferecimento de recursos financeiros, tecnológicos e na permanente valorização da profissão docente em todos os seus níveis como formas de valorização do papel da educação na formação humana, profissional e identitária da sociedade brasileira.

Nesse aspecto, entre outras, as discussões em torno da Base Nacional Comum Curricular (BNCC) assumem grande relevância acadêmica, política e social, tanto pelo seu caráter normativo para o desenvolvimento das diretrizes do trabalho pedagógico cotidiano na escola infantil e no ensino fundamental oferecido pelas redes públicas e particulares; quanto para aqueles que atuam no âmbito da pesquisa acadêmica educacional e que estão preocupados em contribuir com a diminuição das enormes desigualdades que se registram nas relações de ensino e aprendizagem em nosso país. 
No bojo processual e polêmico dessas discussões, em vigência há mais de dez anos, a lei 10639/03 veio dar novo impulso às pesquisas acerca da participação da população afrodescendente na sociedade brasileira, em especial no campo da educação e seus inúmeros desdobramentos. Entre avanços e retrocessos, o tema entrou na agenda política do país e tornou-se um dos assuntos mais debatidos ultimamente, muito em razão de sua capilaridade com outros temas afins, como o racismo, a discriminação, a inclusão social e/ou educacional, o "empoderamento" da população negra etc.

Diante desse quadro, como editores da Revista Cadernos de Pós-graduação, lançamos $a$ proposição de organizarmos o dossiê "Educação Escolar Quilombola, Educação das Relações Étnico-Raciais e para o Ensino de História e Cultura Afro-Brasileira e Africana", com o intuito de debater não apenas o legado da referida lei à atual situação da educação brasileira; mas também os desdobramentos futuros que a "questão étnico-racial" pode suscitar para nossa sociedade ávida de profundas transformações sociais.

Nosso intuito foi o de colaborar com a reflexão e com a compreensão de uma temática que tem profundas raízes históricas de grande importância nos dias atuais; como também deixar registrado a premissa e a compreensão que temos de que a relação que se estabelece entre os currículos que são formulados, apresentados, discutidos e socializados desde a educação infantil, passando pelo ensino fundamental, até alcançar o ensino superior e a formação das identidades na sociedade brasileira é muito grande.

Tal preocupação se funda no reconhecimento da importância da presença de uma rica e crescente diversidade sociocultural, com um sem número de manifestações culturais, religiosas, alimentares, musicais e comportamentais; sem falar das diferenças 


\section{Cadernos}

A EDUCAÇÃO ESCOLAR QUILOMBOLA, EDUCAÇÃO DAS RELAÇÕES ÉTNICORACIAIS E PARA O ENSINO DE HISTÓRIA E CULTURA AFRO-BRASILEIRA E AFRICANA E A IMPORTÂNCIA DE SUA PRESENÇA NA BASE NACIONAL COMUM CURRICULAR (BNCC)

dos fenótipos que também se mostram de grande monta na constituição da fisionomia de nós mesmos!

Os horrores da escravidão e a imposição da cultura europeia que foram impostos as nações indígenas e aos povos africanos ao longo de mais de trezentos anos de história não foram capazes de emudecer e de eliminar os traços culturais e a inestimável herança social de toda essa gente na formação da identidade e no sentido civilizatório do povo brasileiro.

Dito isto, esse número da Revista Cadernos de Pós-Graduação, conta, na seção dossiê, com os seguintes manuscritos: Educação do corpo e relações étnico-raciais sob o olhar de professores, de Kalyla Maroun; Identidade quilombola e educação escolar quilombola: contribuições a partir da experiência de um quilombo, de Sandra Nivia Soares de Oliveira; Currículo multicultural como instrumento de empoderamento de escolas quilombolas, autoria de Marcio Antonio Raiol Santos e Carlos Afonso Ferreira Santos; A formação docente continuada para as relações étnico-raciais no Rio de Janeiro: a experiência do programa de estudo do negro na sociedade brasileira (PENESB/UFF), de Vitor Leandro de Souza, Tiago Dionísio da Silva e Tatiane Pacheco de Mattos; Os saberes e fazeres das crianças quilombolas MarajoaraSalvaterra-Pará, de Erica de Sousa Peres e Nazaré Cristina Carvalho; A lei 10.639/03 e as relações étnico-raciais no ambiente escolar: mudanças e permanências, de Nívea Maria Araújo Santana.

Na seção artigos, a revista comtempla os seguintes manuscritos: A formação de educadores e a educação inclusiva: da sensibilidade ético-política à condição humana, de Marisa Soares; O professor surdo universitário: estudo sobre possíveis estigmas, de Emmanuelle Félix Santos; Desafios e surpresas da inclusão de uma criança cega em sala de aula, de Valquiria Bertuzzi Veronesi e Francisca Eleodora 
Santos Severino; Educação, comunicação e mídia: uma abordagem teórica, de Douglas Branco de Camargo, Iris Weiduschat e Alvin Noriler; Políticas de educação especial: análise do plano de educação (2015 - 2025) e diretrizes da educação especial (2012) de Macapá-AP, de Marcia Maria dos Santos, Maria do Carmo Lobato da Silva e Ilma de Andrade Barleta; Políticas de Inclusão e a realidade profissional: a experiência de uma graduanda cega no estágio curricular supervisionado, de Kalina Salaib Springer, Sabrina Mangrich de Assunção e Yanna D'Angelis de Carvalho Gonçalves; Educação inclusiva, os desafios para sua efetivação, de Carla Campos de Oliveira Almeida.

Esse número da Cadernos também conta com as seguintes resenhas: Temas fundamentais na escola da infância, de Ligia de Carvalho Abões Vercelli e Cristiano Rogério Alcântara (Orgs), escrita por Simone Eliane dos Santos Pessanha; Plano Nacional de Educação: diversos olhares, de Andréia Nunes Militão, Fábio Perboni (Orgs), autoria de Sueli do Nascimento e Welcianne Iris de Queiroz; A educação básica pública tem solução?, de Herman Jacobus Cornelis Voorwald, escrita por Carlos Lima Dantas; A vida cotidiana dos adolescentes em conflito com a lei e o envolvimento com práticas delitivas, de Neusa Francisca de Jesus, escrita por Agnaldo Aparecido Geremias; O retrato histórico da formação inicial do professor no Brasil: inquietudes e ponderações, de Lucilene Pisaneschi, autoria de Raquel Silva Santos.

Boa leitura

Ligia Vercelli

Carlos Baner 


\section{Cadernos}

\section{Dossiê temático:}

Educação Escolar Quilombola, Educação das Relações ÉtnicoRaciais e para o Ensino de História e Cultura Afro-Brasileira e Africana

Thematic dossier: Quilombola School Education, Education of Ethnic-Racial Relations and for the Afro-Brazilian and African History and Culture Teaching 


\title{
EDUCAÇÃO DO CORPO E RELAÇÕES ÉTNICO-RACIAIS SOB O OLHAR DE PROFESSORES
}

\author{
EDUCATION OF BODY AND ETHNIC-RACIAL RELATIONS UNDER THE \\ GAZE OF TEACHERS
}

\begin{abstract}
Kalyla Maroun
Doutora em Ciências Humanas/Educação pela Pontifícia Universidade Católica do Rio de Janeiro. Professora Adjunta da Faculdade de Educação da Universidade Federal do Rio de Janeiro. Rio de Janeiro - RJ - Brasil kalylamaroun@gmail.com
\end{abstract}

Resumo: A questão que se pretende responder aqui é: qual o olhar de professores da área de linguagens sobre o tema da educação para as relações étnico-raciais, especialmente aqueles que possuem o corpo como elemento central em suas práticas educativas? Foi realizada análise bibliográfica para a conceituação do termo educação do corpo; exercício analítico apontando como processos de educação do corpo podem dar visibilidade ao tema da educação para as relações étnico-raciais na escola; pesquisa de campo representada por entrevistas com três professores de uma escola do município do Rio de Janeiro: uma professora de Artes Cênicas, uma de Educação Física e um professor de Música. Os dados apontaram para duas categorias analíticas: conhecimento sobre as políticas educacionais voltadas ao tema; práticas educativas, curriculares ou não, com foco nas relações étnico-raciais. Ainda que o tema não seja observado nos planejamentos de todos os professores, há uma sensibilização para com o mesmo.

Palavras-chave: Educação do corpo. Relações étnico-raciais. Professores. Instituições escolares.

Abstract: The question that we intend to answer here is: what are the view teachers about the subject of education for ethnic-racial relations, especially those who have the body as a central element in their educational practices? A bibliographical analysis was carried out for the conceptualization of the term education of body; analytical exercise pointing out how processes education of body can give visibility to the education for ethnic-racial relations in school; field

Cadernos de Pós-graduação, São Paulo, v. 17, n. 2, p. 15-33, jul./dez. 2018. 
research represented by interviews with three teachers from a school in the city of Rio de Janeiro: a Performing Arts teacher, a Physical Education teacher and a Music teacher. The data pointed to two analytical categories: knowledge about educational policies focused on the theme; educational practices, curricular or not, focusing on ethnic-racial relations. Although the theme is not observed in the planning of all teachers, there is awareness about this. Keywords: Education of body. Ethnic-racial relations. Teachers. School institutions.

\section{Introdução}

presente artigo apresenta resultado preliminar de um projeto de pes-
quisa, ainda em desenvolvimento, que pretende inventariar e analisar processos de educação do corpo em instituições escolares que foquem práticas educativas voltadas às relações étnico-raciais

${ }^{1}$. O recorte que se pretende aqui neste momento é apontar o olhar de professores para o trato pedagógico com o tema da educação para as relações étnico-raciais, especialmente aqueles que possuem, em suas áreas disciplinares, o corpo e pedagogias corporais como elementos centrais em suas práticas educativas, como explicitaremos adiante.

O desenvolvimento deste trabalho foi dividido em três etapas. A primeira delas consistiu em revisão e análise bibliográfica no intuito de conceituarmos o que pode ser compreendido como educação do corpo. A segunda versou sobre um esforço analítico em apontar como processos de educação e agenciamento do corpo em instituições escolares pode dar visibilidade e nos trazer indícios relevantes acerca do tema da educação para as relações étnico-raciais. Ambas as etapas foram realizadas ao longo do ano de 2017. A terceira e última etapa incidiu em pesquisa de campo realizada em uma escola federal situada no município do Rio de Janeiro, que oferece todo o Ensino Fundamental e Médio. Nesta, realizamos entrevistas semiestruturadas com três professores: um professor de Música, uma professora de Educação Física e outra de Artes Cênicas. A justificativa para a escolha de professores destas áreas disciplinares estará explicitada posteriormente, já que a mesma compõe a estrutura argumentativa do artigo. A seleção dos docentes, propriamente dita, ocorreu mediante aceitação em participar da pesquisa

Cadernos de Pós-graduação, São Paulo, v. 17, n. 2, p. 15-33, jul./dez. 2018. 
como colaborador e, também, pelo reconhecimento da qualidade do trabalho pedagógico que os mesmos possuem na instituição de ensino investigada. As entrevistas ocorreram entre os meses de novembro e dezembro de 2017 e foram realizadas na própria escola. O objetivo das entrevistas foi levantar informações sobre como os professores compreendem a educação para as relações étnico-raciais em suas respectivas disciplinas, bem como desvelar se tal conteúdo é, ou não, devidamente inserido em seus planejamentos e práticas educativas. Nesse sentido, a intenção é trazer um panorama sobre como alguns docentes da área de linguagens, área esta que possui estreita ligação com diferentes formas de agenciamento do corpo, quando comparados com docentes de outras disciplinas curriculares, colocam-se e/ou trabalham pedagogicamente com o tema. Por fim, apresentamos uma breve análise dos dados empíricos encontrados, conscientes de que uma etapa posterior relevante para dar continuidade à pesquisa aqui apresentada deve se voltar a uma observação de aulas e práticas pedagógicas dos mesmos. A partir de tal observação será possível inventariar e analisar processos de educação do corpo que tenham, ou não, foco em uma educação para as relações étnicoraciais, pautada na ampliação da reflexão sobre as relações entre negros, brancos e outros grupos étnico-raciais na sociedade brasileira, desmistificando o racismo e colaborando para a superação da discriminação racial (GOMES, 2005a). Como aponta Munanga (2005), refletir e debater sobre a questão racial no Brasil não deve interessar somente às pessoas que pertencem ao grupo étnico/racial negro. Tal debate é uma questão social, política e cultural de todos os brasileiros. Discutir o racismo, por exemplo, ao contrário do que é propagado pelo senso comum, não significa acirrar conflitos entre diferentes grupos étnico-raciais. Pelo contrário, é o silenciamento sobre esse debate que reforça a existência do racismo, da discriminação e da desigualdade racial (GOMES, 2005a).

Cadernos de Pós-graduação, São Paulo, v. 17, n. 2, p. 15-33, jul./dez. 2018. 
Destacamos que os procedimentos burocráticos e éticos para a entrada em campo na instituição escolar selecionada foram rigorosamente seguidos. Além disso, os professores interlocutores deste trabalho foram assegurados quanto ao anonimato das informações coletadas em publicações e/ou apresentações públicas do estudo.

\section{Educação do corpo, relações étnico-raciais e escola}

Chamamos atenção para o fato de que a escola, enquanto instituição social, cria, naturaliza e legitima agenciamentos do corpo de forma a moldá-lo em função das estruturas sociais nas quais este se insere. Como nos lembra Oliveira (2006), a transição de um modelo de educação doméstica para o da escola graduada, no século XIX, foi acompanhada de uma série de dispositivos que redefiniram o papel do corpo no novo modelo educativo instaurado. Podemos dizer, portanto, que a instituição escolar é, dentre outros espaços de sociabilidade, como academias de ginástica, clubes esportivos, centros religiosos, centros culturais e artísticos, etc, um lócus privilegiado para observação de práticas sistemáticas de educação do corpo.

Ressaltamos que o conceito de educação do corpo com o qual estamos trabalhando aqui pode ser representado pelo que Mauss (2003) chama de transmissão de técnicas corporais. Segundo o autor, determinadas técnicas corporais são transmitidas por meio da imitação prestigiosa que confere ao aprendiz a força da tradição presente tanto nas técnicas do fazer (laborais, sociais e festivas), quanto nas interdições corporais (gestuais, sexuais e alimentares), em diversos contextos educativos/formativos. O corpo, em fruição no cotidiano, expressa costumes específicos do grupo ao qual pertence, revelando pelas expressões corporais os traços particulares do indivíduo e da coletividade a qual pertence, já que é por meio da transmissão e reprodução destas técnicas corporais que a estrutura social fixa sua marca identitária sobre os indivíduos.

Cadernos de Pós-graduação, São Paulo, v. 17, n. 2, p. 15-33, jul./dez. 2018. 
O que brevemente queremos demonstrar é que o corpo é um objeto de intervenção e modelação permanentes, o que ocorre tanto em espaços institucionalizados a exemplo da escola - como em espaços educativos não formais ou informais. No caso da instituição escolar, os corpos de alunos e alunas estão submetidos às diferentes experiências curriculares que compõem os tempos e espaços escolares. Assim, a análise das atividades e/ou disciplinas curriculares voltadas à educação sistemática do corpo, como aulas de canto e música, de educação física, de teatro, de culinária, de dança, de sexualidade, de saúde e higiene, dentre outras, pode representar um caminho para a compreensão de como o corpo é agenciado pelas culturas escolares.

O trabalho de Maroun e Santos (2017) apresenta um esforço inicial de análise da relevância de se olhar os processos de agenciamento do corpo presentes na instituição escolar como plataforma para a observação da existência, ou não, de trabalho pedagógico voltado à educação das relações étnico-raciais. O argumento central das autoras recai sobre o protagonismo que a educação do corpo ocupa em políticas educacionais específicas voltadas ao tema da educação para as relações étnico-raciais, como poderemos ver adiante.

As políticas educacionais sobre as quais as autoras se debruçaram foram as seguintes: Lei Federal 10.639/2003 (BRASIL, 2003), que trouxe a obrigatoriedade do ensino da história e cultura afro-brasileira e africana na Educação Básica; Diretrizes Curriculares Nacionais para a Educação das Relações Étnico-Raciais e para o Ensino de História e Cultura Afro-Brasileira e Africana (BRASIL, 2004), que trazem contribuições importantes para a ampliação do foco dos currículos escolares na direção da diversidade cultural, social e racial; Lei Federal 11.645/2008 (BRASIL, 2008), que amplia a Lei 10.639/2003 ao inserir a obrigatoriedade do ensino da história e da cultura dos povos indígenas na Educação Básica; Diretrizes Curriculares Nacionais para a Educação Es- 
colar Indígena (BRASIL, 2012), que garantem uma educação intercultural e diferenciada para escolas indígenas; e, por fim, as Diretrizes Curriculares Nacionais para a Educação Escolar Quilombola, publicadas em 20 de novembro de 2012 (MAROUN; SANTOS, 2017).

As políticas educacionais citadas acima, ao indicarem a necessidade da valorização e do reconhecimento das histórias e das culturas afro-brasileiras, indígenas e quilombolas nos currículos escolares, trazem o protagonismo do corpo nesse processo. Podemos dizer, ainda, que a educação do corpo, por meio da transmissão de determinadas técnicas corporais, possui destaque no cenário de tais políticas, uma vez que são por meio de gestos, condutas e saberes expressos pelo corpo que identidades étnicas e/ou raciais são construídas e reafirmadas.

As Leis Federais 10.639/2003 e 11.645/2008, ao trazerem a obrigatoriedade do ensino da história e da cultura africana, afro-brasileira e indígena na Educação Básica, por exemplo, indicam que tais conteúdos sejam trabalhados nas disciplinas de Artes, História e Literatura. Compreendemos que a disciplina de Artes apresenta estreita relação com a educação do corpo no contexto escolar, seja por meio do ensino de danças e práticas culturais, ou mesmo através do teatro, das artes visuais e da música. Já nas áreas de História e Literatura, narrativas, memórias e culturas afro-brasileiras e indígenas, por si só, podem ser transmitidas, também, por meio de saberes corporais, isto é, a escola pode construir pedagogias corporais voltadas à valorização das diferenças e das identidades étnicas e/ou raciais. Apesar de não ser apontada pelas Leis 10.639/2003 e 11.645/2008, a educação para as relações étnico-raciais também pode ser alargada para a área da Educação Física, cujo objeto de ensino se volta à cultura corporal de movimento. Como indicam alguns autores (RODRIGUES, 2010; PINTO; MACAMO; AZEVEDO, 2014), a inserção de determinadas práticas corporais e esportivas no currículo da área, aliada a práticas pedagógicas críticas e problematizadoras, torna-se uma

Cadernos de Pós-graduação, São Paulo, v. 17, n. 2, p. 15-33, jul./dez. 2018. 
estratégia relevante para o trabalho pedagógico com o tema da educação para as relações étnico-raciais.

Em relação às Diretrizes Curriculares Nacionais para a Educação das Relações Étnico-Raciais e para o Ensino de História e Cultura Afro-Brasileira e Africana (BRASIL, 2004), estas destacam a valorização da identidade e do patrimônio histórico-cultural afro-brasileiro na Educação Básica. Em nossa análise compreendemos que o documento sugere, também, a inserção de práticas educativas atreladas a um roteiro específico de educação do corpo que combata, de um lado, o racismo e, de outro, a invisibilidade da população negra e indígena no cotidiano escolar. Logo, o documento preconiza: o rompimento com imagens negativas de negros e povos indígenas, forjadas por meios de comunicação diversos; a afirmação de identidades étnicas e/ou raciais; a valorização da oralidade, da corporeidade e da arte; educação patrimonial baseada no aprendizado a partir do patrimônio cultural afro-brasileiro, visando sua preservação e difusão; a valorização dos anciãos e dos griots como guardiões dos saberes tradicionais. O agenciamento do corpo que vai assegurar o ensino da história e da cultura afrobrasileira e africana, portanto, deverá destacar as identidades negras manifestadas tanto no cotidiano, quanto em celebrações como congadas, moçambiques, ensaios, maracatus, rodas de samba, etc.

Tanto a educação escolar indígena como a quilombola, por meio de suas respectivas diretrizes curriculares (BRASIL, 2012a; BRASIL, 2012b) apresentam, em nossa análise, alguns destaques referentes à educação do corpo nas instituições escolares que atendem tais populações, a saber: hábitos, costumes, normas, festividades, ritos, bem como práticas culturais específicas devem se estender do espaço da comunidade para o escolar; alimentação e infraestrutura escolares devem ser condizentes com a cultura das comunidades; lideranças comunitárias, como os sábios no caso indígena, e os anciãos (griots), devem estar atuando junto à escola, levando a ela seus saberes e suas 
corporalidades. A seguir um trecho das Diretrizes Curriculares Nacionais para a Educação Escolar Quilombola (BRASIL, 2012, p. 3), Artigo 1, inciso 1:

I- Organiza precipuamente o ensino ministrado nas instituições educacionais fundamentando-se, informando-se e alimentando-se: a) da memória coletiva; b) das línguas reminiscentes; c) dos marcos civilizatórios; d) das práticas culturais; e) das tecnologias e formas de produção do trabalho; f) dos acervos e repertórios orais; g) dos festejos, usos, tradições e demais elementos que conformam o patrimônio cultural das comunidades quilombolas de todo o país; h) da territorialidade.

Nessa linha de contextualização sobre educação do corpo, relações étnico-raciais e escola, apresentada por meio de uma breve análise de algumas políticas educacionais que sugerem como tal debate pode (ou deveria) estar presente no campo empírico, indagamos: como professores da área de linguagens compreendem o tema da educação para as relações étnico-raciais em seus respectivos planejamentos e práticas pedagógicas? De que forma determinados agenciamentos do corpo, ou roteiros de educação corporal específicos, podem contribuir para a valorização e reconhecimento das identidades étnicas e/ou raciais? Quais os maiores desafios para que se apresentam aos professores no trabalho pedagógico com o tema?

Para Maroun e Santos (2017) há um processo de construção identitária que ocorre por meio de um roteiro específico de educação do corpo voltado aos grupos minoritários majoritariamente em espaços educativos/formativos diferentes da escola. Devemos refletir acerca de como a escola e seu corpo docente, a partir de uma organização espacial, curricular pedagógica e temporal próprias, pode - ou não - ressignificar o corpo e determinadas corporalidades, a fim de reconhecer e valorizar as diferenças. Entretanto, estas devem ser concebidas como realidades sócio-históricas dinâmicas, em processo contínuo de construção-desconstrução-construção, atravessadas por questões 
de poder, constitutivas dos indivíduos e dos grupos sociais (CANDAU, 2011). Em uma sociedade que atualmente coloca na agenda a noção do respeito às diferenças identitárias (gênero, raça, etnia, etc.), o tema das intervenções materializadas nas práticas educativas do/no/sobre o corpo devem ser problematizadas nas diferentes áreas curriculares, em especial na de linguagens.

\section{O olhar dos professores}

Como já explicitado, a escolha dos professores interlocutores deste trabalho foi realizada mediante duas questões complementares: possuir destaque positivo no desempenho pedagógico realizado na instituição pesquisada, o que foi reconhecido a partir de nossa observação participante ao longo do ano de 2017; representar cada uma das áreas de linguagem, ofertadas pela instituição que, segundo nossa argumentação anterior, possui relação com práticas sistemáticas de educação do corpo (Artes Cênicas, Música e Educação Física). A professora de Artes Cênicas atua com o Ensino Médio. Já os professores de Educação Física e Artes atuam no Ensino Fundamental, primeiro e segundo segmento, respectivamente.

O primeiro dado empírico que nos chamou a atenção foi o nível de conhecimento sobre as políticas educacionais voltadas ao tema da educação para as relações étnico-raciais. Apesar de neste ano de 2018 a Lei Federal 10.639/2003 completar quinze anos de existência, por exemplo, ainda podemos encontrar exemplo de docentes que nunca a leram efetivamente. Ou ainda, que não possuem conhecimento sobre a agenda de políticas e documentos normativos que compõe tal debate.

Claro que eu conheço as leis, mas nunca li na verdade. Se você me perguntar exatamente quais tratam e quais são eu não vou saber, porque infelizmente eu nunca estudei as leis. Mas sei do que elas

Cadernos de Pós-graduação, São Paulo, v. 17, n. 2, p. 15-33, jul./dez. 2018. 
tratam e sei que aqui na escola tem uma discussão grande pelo pessoal de Língua Portuguesa, que trata mais do debate que a gente (Professora de Artes Cênicas).

Por outro lado, percebemos que quando as políticas educacionais são, ao menos, conhecidas por parte de alguns docentes, isso pode ser resultado de uma conclusão mais recente da licenciatura, isto é, de um debate assegurado pela formação inicial que não é continuada no chão da escola. "Eu conheço as leis mais pelo debate que tem na Faculdade de Educação do que dentro da escola. A gente ouve sim, mas eu vejo pouco debate aqui na escola" (Professora de Educação Física).

Um olhar crítico e problematizado sobre as políticas voltadas ao tema da educação para as relações étnico-raciais foi encontrado no discurso do professor de Música.

As leis que tratam da história e também da cultura dos negros e indígenas no currículo do Ensino Básico são muito importantes. Deveriam estar na discussão de todas as escolas. Cada contexto é um contexto e aqui é uma escola predominantemente branca... os alunos negros são minoria. E, por outro lado, você vê muitas pessoas que estão aqui em outras funções da escola, consideradas em hierarquia mais baixas: limpeza, inspetores de alunos... Aí sim você vê pardos e mestiços. Então isso acaba expressando uma suposta hierarquia de etnias que não deveria ser assim. Não tem motivo de uma sociedade equilibrada ser assim. Por esse motivo de desequilíbrio, essa coisa deveria estar presente aqui. Mas não há muita discussão. Ultimamente alguns têm se manifestado quanto a isso e existe um grupo de alunos negros que está fazendo um grupo de reunião e estudo sobre essa questão racial. Eu vejo que ainda é uma coisa pequena, que precisa crescer. É muito importante e muito necessária a participação de todos, dos alunos, professores, licenciados e funcionários nesse debate.

Como indica Gomes (2005b) é relevante que educadores ressignifiquem suas práticas, fomentando novas posturas e novos debates frente à questão étnico-racial, contribuindo para que esta ultrapasse os limites dos movimentos sociais e das ONG's. A autora traz uma proposição de temas a serem trabalhados na escola para alavancar 
uma educação para as relações étnico-raciais, tendo como base, em nossa análise, uma estreita relação com agenciamentos específicos do corpo, bem como com as áreas disciplinares em foco neste estudo, como podemos observar abaixo:

Assim, poderemos realizar discussões na escola que trabalhem temas como: a influência da mídia, a religião, a cultura, a estética, a corporeidade, a música, a arte, os movimentos culturais, na perspectiva afro-brasileira. Essas e outras temáticas podem e devem ser realizadas ao longo do processo escolar e não somente nas datas comemorativas, na semana do folclore ou durante a semana da cultura. (GOMESb, 2005, p. 151).

As áreas disciplinares que se apresentam como foco deste estudo (Artes Cênicas, Música e Educação Física), portanto, podem ser consideradas um lócus privilegiado para o desenvolvimento dos temas acima sugeridos, temas estes que possuem, no corpo, uma plataforma fundamental de aprendizado.

O segundo dado encontrado que merece ser destacado se volta a práticas educativas dos docentes entrevistados, curriculares ou não, que tem como foco o debate sobre as relações étnico-raciais. Adiantamos, contudo, que segundo os professores entrevistados, não há em nenhuma das suas respectivas áreas disciplinares, um planejamento sistematizado das equipes que leve em consideração tal conteúdo. Porém, em seus trabalhos docentes individualizados o cenário é diferenciado. Nas Artes Cênicas e na Educação Física iniciativas pontuais parecem ocorrer mediante o aparecimento de questões que norteiam as relações ético-raciais durante o cotidiano das aulas. Já na Música, o professor revela uma prática crítica e problematizadora sobre o tema em suas aulas, valorizando especialmente a contribuição africana e afro-brasileira para a música brasileira e americana. Vejamos as respectivas falas dos professores abaixo:

$\mathrm{Na}$ verdade a gente não tem como um tema porque a gente não trabalha com temas dentro do currículo de Artes Cênicas. A gente 
trabalha, na verdade, com os eixos da linguagem. Aí um aluno apresenta uma cena em que isso aparece como problemática, ou como preconceito, daí a gente vai tratar, vai ter uma discussão. [...] Porque o trabalho cênico, trabalho criativo, ele traz muito essas questões, a questão do racismo. Outra coisa que o setor fez, por exemplo, esse ano, foi um evento de contação de histórias e um dia foi o tema dos contos africanos com uma militante negra (Professora de Artes Cênicas).

De acordo com Silva (2005), o preconceito e a estratificação social sempre estiveram presentes no teatro brasileiro, que delegava ao negro o papel de coadjuvante na cena nacional. Assim, o personagem negro estaria confinado a abrir portas, a servir de caricatura do empregado doméstico e a sofrer o determinismo de uma posição social de servidor. Portanto, reconhecer, problemaizar e desconstruir os estereótipos étnicos presentes nas Artes Cênicas e no teatro brasileiro poderia vir a contribuir para a reafirmação de uma identidade negra dos alunos por meio de autoidentificação positiva consigo mesmo.

Abaixo outra prática educativa voltada ao tema das relações étnico-raciais que, apesar de não ter sido planejada, ou seja, de não estar presente no currículo, ocorreu no ano letivo de 2017:

Falando por mim na experiência que eu tive, pelo menos ano passado a gente teve um trimestre que a gente trabalhou com jogos africanos, indígenas e brasileiros. Trouxe alguns convidados para discutir com a minha turma de primeiro ano e a gente discutiu. Mas não foi algo proposto ou que estava no currículo para trabalhar (Professora de Educação Física).

O professor de Música, como já descrito anteriormente, representa uma perspectiva diferenciada do trabalho pedagógico com o tema em questão, considerando o currículo um documento de identidade (SILVA, 2010). Nessa perspectiva, o currículo é sempre resultado de uma seleção capaz de justificar, a partir da escolha dos conteúdos, 
o porquê de determinados conhecimentos em detrimento de outros, refletindo determinações e tensões entre grupos sociais e políticos de determinados contextos históricos e culturais, como podemos observar no discurso do professor:

A gente procura enfatizar a importância da influência do negro na parte rítmica, no canto. Isso aparece bastante nas minhas aulas e até buscando mostrar a expressão dos descendentes africanos como artistas, e não só como escravos que é o que aparece muito na escola, né?! [...] Não pegar a história da escravidão, das mazelas, mas sim das contribuições e das coisas boas que essa miscigenação trouxe. Então, isso acontece muito nos ritmos africanos que a gente tem no Brasil e a gente trabalha bastante em sala de aula, especialmente aqui do Rio, o samba é um em especial, mas também ritmos estrangeiros como o blues, jazz, onde os negros foram mais do que importantes e influenciadores, foram peças realmente decisivas, né?! (Professor de Música).

A partir da transcrição acima percebemos que uma educação para as relações étnico-raciais é tomada como uma perspectiva de trabalho pedagógico dentro do currículo da disciplina desse professor de Música, o que não foi observado na fala das outras professoras. A professora de Educação Física, por exemplo, apesar de conhecer as leis apresenta dificuldade em trabalhar com a temática: "eu considero um tema difícil de trabalhar as vezes eu não sei como os alunos vão receber, não sei tratar, então eu considero que eu ainda tenho que estudar mais para trabalhar com esse tema".

No caso do professor de Música, observamos uma valorização das contribuições e influências da cultura negra tanto para com a música brasileira, como com a americana. Se levarmos em conta as teorias pós-críticas do currículo (SILVA, 2010), constataremos alguns processos de dominação dos conteúdos escolares, centrados no silenciamento e na invisibilidade das questões voltadas às relações étnico-raciais, a exemplo do que o professor traz ao destacar que a escola tende a propagar de forma mais predominante a ideia do negro enquanto escravo, desprovido de bens culturais, 
sociais, artísticos, econômicos, etc. Porém, ao serem inseridas na educação formal as especificidades daquilo que pode ser entendido como "diferente", um real sentido pode ser dado à escolarização.

Diante do exposto, trabalhar pedagogicamente as diferenças relacionadas às identidades étnicas e/ou raciais na escola pressupõe um reconhecimento e uma valorização positiva destas, desconstruindo visões estereotipadas de certas identidades e desenvolvendo a autoestima de alunos e alunas que pertencem a grupos ditos como minoritários, que são alvo de discriminação. Além disso, trabalhar os conflitos que emergem no cotidiano escolar oriundos de tais diferenças também se torna uma estratégia relevante para uma educação para as relações étnico-raciais, já que o grande desafio seria transformar a diversidade conhecida e reconhecida em uma vantagem pedagógica. (CANDAU, 2011).

Por fim, ainda que não tenha sido observada a incorporação do tema da educação para as relações étnico-raciais no planejamento curricular de duas interlocutores deste trabalho, percebemos que há uma sensibilização para o mesmo representada, em seus discursos, ora pelas iniciativas pontuais no cotidiano de suas práticas, ora pela compreensão dos possíveis avanços proporcionados pelas políticas educacionais relacionadas ao tema, que convidam o corpo docente das instituições de ensino a um trabalho pedagógico ressignificado.

Não é um currículo papel e a gente vai criando esses espaços que surgem na Arte, na relação da criação, em como a gente vai construindo as relações. Não temos um currículo engessado, mas temos um currículo flexível em que a gente pode trabalhar o conteúdo do aluno (Professora de Artes Cênicas).

Pelo menos eu vejo que é um avanço, pelo menos tem a lei e todo mundo sabe que ela existe. E isso pra mim já é um passo importante. Antes partia de cada um, um ou outro que se sensibilizava com o tema. Mas agora pelo menos tem uma lei que incomoda, pelo menos

Cadernos de Pós-graduação, São Paulo, v. 17, n. 2, p. 15-33, jul./dez. 2018. 
cutuca e faz pensar. Mas falta a lei ser feita na prática (Professora de Educação Física).

\section{Considerações finais}

O primeiro destaque que merece ser feito é indicarmos uma nova agenda de pesquisas para o tema da educação para as relações étnico-raciais em instituições escolares por meio da análise de processos de educação e agenciamento do corpo presentes em seus respectivos espaços. Pesquisas no campo da educação apontam a relação entre educação do corpo em contextos educativos não formais e a reafirmação de identidades étnicas e/ou raciais (ALMEIDA; ALMEIDA; GRANDO, 2010; MAROUN, 2013; ROSA, 2009). Porém, tal relação ainda é pouco explorada quando nos voltamos ao chão da escola, isto é, à educação formal. Devemos destacar a importância de pesquisas que apresentem um olhar atento para a organização espacial, temporal, curricular e pedagógica, no intuito de observar se os processos de agenciamento dos corpos reconhecem, ou não, as diferenças em instituições escolares.

O segundo ponto que deve ser evidenciado é a potencialidade com a qual a área de linguagens, representada aqui pelas Artes Cênicas, Educação Física e Música, pode explorar o tema em debate, principalmente pelas mesmas possuírem, no/sob/pelo corpo, foco de determinadas práticas educativas.

A terceira questão que nos chama atenção é que o debate sobre a educação para as relações étnico-raciais na escola, a partir dos dados coletados, parece priorizar mais o conteúdo da história e cultura africana e afro-brasileira, do que a história e cultura dos povos indígenas, observação esta que merece um maior aprofundamento em pesquisas futuras.

Cadernos de Pós-graduação, São Paulo, v. 17, n. 2, p. 15-33, jul./dez. 2018. 
Por fim, o presente estudo se predispôs a trazer algumas contribuições iniciais para inventariarmos, em contextos empíricos diferenciados, pedagogias e técnicas corporais, socializadas e valorizadas em ambientes escolares, cujo foco seja a educação para as relações étnico-raciais. Para um aprofundamento na temática, novas imersões em campo devem ser realizadas a fim de que seja possível trazer visibilidade e ressignificação acerca de práticas educativas outras.

\section{Referências}

ALMEIDA, A. J. M.; ALMEIDA, D. M. F.; GRANDO, B. S. As práticas corporais e a educação do corpo indígena: a contribuição do esporte nos jogos dos povos indígenas. Revista Brasileira de Ciências do Esporte, v. 32, n. 2-4, p. 59-74, 2010.

BRASIL. Ministério da Educação. Lei Federal 10639 de 9 de janeiro de 2003. Altera a Lei no 9.394, de 20 de dezembro de 1996, que estabelece as diretrizes e bases da educação nacional, para incluir no currículo oficial da Rede de Ensino a obrigatoriedade da temática "História e Cultura Afro-Brasileira". Brasília, DF, 2003. Disponível em: <http://www.planalto.gov.br/ccivil_03/LEIS/2003/L10.639.htm>. Acesso em: 05 fev. 2018.

BRASIL. Ministério da Educação. Diretrizes curriculares nacionais para a educação das relações étnico-raciais e para o ensino de história e cultura afro-brasileira e africana. Conselho Nacional de Educação - Câmara de Educação Básica (CNE/CEB). Brasília, DF, 2004. Disponível em: <http://portal.mec.gov.br/cne/arquivos/pdf/res012004.pdf>. Acesso em: 05 fev. 2018.

BRASIL. Ministério da Educação. Lei Federal 11645 de 10 de março de 2008. Altera a Lei no 9.394, de 20 de dezembro de 1996, modificada pela Lei no 10.639 , de 9 de janeiro de 2003, que estabelece as diretrizes e bases da educação nacional, para incluir no currículo oficial da rede de ensino a obrigatoriedade da temática "História e Cultura Afro-Brasileira e Indígena". Brasília, DF, 2008. Disponível em: <http://www.planalto.gov.br/ccivil_03/_ato2007-2010/2008/lei/111645.htm >. Acesso em: 05 fev. 2018. 
BRASIL. Ministério da Educação. Diretrizes Curriculares Nacionais para a Educação Escolar Indígena. Conselho Nacional de Educação - Câmara de Educação Básica (CNE/CEB). Brasília, DF, Parecer no 13, 2012a. Disponível em: $<$ http://portal.mec.gov.br/index.php?option=com_docman\&view=download\&alias=10806-pceb013-12-pdf\&category_slug=maio-2012-pdf\&Itemid=30192<http://portal.mec.gov.br/index.php?option=com_docman\&view=download\&alias=10806-pceb013-12-pdf\&category_slug=maio2012-pdf\&Itemid=30192> . Acesso em: 5 fev. 2018.

BRASIL. Ministério da Educação. Diretrizes Curriculares Nacionais para a Educação Escolar Quilombola. Conselho Nacional de Educação - Câmara de Educação Básica (CNE/CEB). Brasília, DF, Parecer nº 16, 2012b. Disponível em: <http://portal.mec.gov.br/index.php?option=com_docman\&view=download\&alias=11091-pceb016-12\&category_slug=junho-2012-pdf\&Itemid=30192>. Acesso em: 5 fev. 2018.

CANDAU, V. M. F. Diferenças culturais, cotidiano escolar e práticas pedagógicas. Currículo sem Fronteiras, v.11, n.2, p.240-255, 2011.

GOMES, N. L. Alguns termos e conceitos presentes no debate sobre relações raciais no Brasil: uma breve discussão. In: Educação antiracista: caminhos abertos pela Lei Federal $n^{o}$ 10.639/03. Brasília: Ministério da Educação, Secretaria de Educação Continuada, Alfabetização e Diversidade, 2005a, p. 39-62.

GOMES, N. L. Educação e Relações Raciais: Refletindo sobre algumas estratégias de atuação. In: MUNANGA, K. (Org.). Superando o racismo na escola. Brasília: Ministério da Educação, Secretaria de Educação Continuada, 2005b, p. 143-154.

MAROUN, K. Jongo e educação: a construção de uma identidade quilombola a partir de saberes étnico-culturais do corpo. Tese (Doutorado em Educação) - Programa de Pós-graduação em Educação, Pontifícia Universidade Católica do Rio de Janeiro, 2013.

MAROUN, K.; SANTOS, M. A. C. dos. Educação do corpo e relações étnico-raciais na escola. In: Anais do IX Seminário Internacional Redes Educativas e Tecnologias, Rio de Janeiro, 2017, p. 1-10. 
MAUSS, M. As técnicas do corpo. In: MAUSS, M. Sociologia e antropologia. São Paulo: Cosac Naify, 2003, p. 399 - 422.

MUNANGA, K. (Org.). Superando o racismo na escola. Brasília: Ministério da Educação, Secretaria de Educação Continuada, 2005.

OLIVEIRA, M. A. T. A título de apresentação - Educação do corpo na escola brasileira: teoria e história. In: OLIVEIRA, M. A. T. (Org.). Educação do Corpo na Escola Brasileira. Campinas: Autores Associados, 2006.

PINTO, F. M.; MACAMO, A. J.; AZEVEDO, N. Ensinando práticas corporais de origem afrobrasileira e africana na educação física escolar. Revista Brasileira de Ciências do Esporte, v. 36, n. 2, Supl., p. S370-S384, 2014.

RODRIGUES, A. C. L. A educação física escolar e LDB: assumindo a responsabilidade na aplicação das leis 10.639/03 e 11.645/08. Revista Reflexão e Ação, v.18, n.1, p.125-150, 2010.

ROSA, J. A. A. Encontrei minhas origens: um olhar do ator sobre a construção da identidade negra a partir do grupo de teatro caixa preta. Trabalho de Conclusão de Curso (Graduação em Licenciatura em Teatro). Universidade Federal do Rio Grande do Sul, 2009.

SILVA, M. L. J. da. As artes e a diversidade étnico-cultural na escola básica. In: MUNANGA, K. (Org.). Superando o racismo na escola. Brasília: Ministério da Educação, Secretaria de Educação Continuada, 2005, p. 125-143.

SILVA, T. T. da. Documentos de identidade: uma introdução às teorias de currículo. Belo Horizonte: Autêntica, 2010.

\section{Notas:}

${ }^{1}$ Tal subprojeto está vinculado a um projeto de pesquisa guarda-chuva, cujo título é "Educação do Corpo em Instituições Escolares". Este último tem como foco compreender os agenciamentos e

Cadernos de Pós-graduação, São Paulo, v. 17, n. 2, p. 15-33, jul./dez. 2018. 
processos de educação corporal presentes em escolas de diferentes contextos étnicos, sociais e culturais.

recebido em 28 fev. 2018 / aprovado em 31 jul. 2018

Para referenciar este texto:

MAROUN, K. Educação do corpo e relações étnico-raciais sob o olhar de professores. Cadernos de Pós-graduação, São Paulo, v. 17, n.2, p. 15-33, jul./dez. 2018. Disponível em: $<$ https://doi.org/10.5585/cpg.v17n2.8409>. 


\title{
IDENTIDADE QUILOMBOLA E EDUCAÇÃO ESCOLAR QUILOBOLA: CONTRIBUIÇÕES A PARTIR DA EXPERIÊNCIA DE UM QUILOMBO
}

\author{
QUILOMBOLA IDENTITY AND QUILOMBOLA SCHOOL EDUCTION: \\ CONTRIBUTIONS FROM THE EXPERIENCE OF A QUILOMBO
}

\author{
Sandra Nivia Soares de Oliveira \\ Doutora em educação pela Universidade Federal da Bahia. Professora adjunta da \\ Universidade Estadual de Feira de Santana. Bahia - BA - Brasil. \\ sandraniviasoares@gmail.com
}

Resumo: Neste trabalho, toma-se o processo de construção da identidade do quilombo de Mangal e Barro Vermelho, situado no Oeste da Bahia-Brasil, compreendendo que sua história e seu processo de construção da identidade podem contribuir para a formação de professores, no debate sobre a educação escolar quilombola e na efetivação de suas diretrizes, entendendo quilombo como uma categoria dinâmica que se atualiza no tempo, ressaltando os diversos caminhos para a construção da identidade quilombola e a necessidade de atentar a essa questão nas discussões sobre a educação de quilombolas. Este trabalho toma como referência os dados de pesquisa de mestrado, ancorada nos aportes teórico-metodológicos da história oral, e a experiência da autora na formação de professores.

Palavras-chave: Educação Escolar Quilombola. Quilombo. Identidade Negra.

\begin{abstract}
In this work, the process of constructing the identity of the quilombo of Mangal and Barro Vermelho, situated in the west of Bahia-Brazil, is carried out, understanding that its history and its identity-building process can contribute to the formative process of teachers in the debate about quilombola school education and the implementation of its guidelines, understanding quilombo as a dynamic category that is updated in time, highlighting the different paths for the construction of quilombola identity and the need to address this issue in the
\end{abstract}

Cadernos de Pós-graduação, São Paulo, v. 17, n. 2, p. 35-54, jul./dez. 2018. 
discussions about quilombola education. This work takes as reference the data of masters research anchored in the theoretical-methodological contributions of oral history and the author's experience in teacher education.

Key-Words: Quilombola School Education. Quilombo. Black Identity.

\section{Introdução}

articipando como formadora do Curso de Formação de Professores Edu-
cação Escolar Quilombola (FORMEEQ) - uma parceria entre a Universidade Federal do Recôncavo Baiano e a Secretaria de Educação do Município de Feira de Santana, senti necessidade de revisitar minha dissertação de mestrado De Mangaz̧eiros a Quilombolas: Terra Educação e Identidade em Mangal e Barro Vermelho, defendida no ano de 2006, na Universidade do Estado da Bahia (UNEB), por conta dos questionamentos feitos por dois cursistas acerca da concepção de quilombo e da identidade quilombola de/em algumas comunidades.

No trabalho realizado no FORMEEQ, percebia-se, entre os professores, o conflito que se instalou após o reconhecimento e titulação de algumas destas comunidades. Professores que trabalhavam na comunidade, há anos, de repente não sabiam o que ensinar e nem como ensinar aos mesmos alunos. Uma fala em especial chamou a minha atenção: "professora, agora que eles viraram quilombolas, estou confusa." Creio que este conflito não seja de uma professora em particular; por esta razão, me senti desafiada a construir um texto que possa auxiliar esses professores e professoras na compreensão do que seja quilombo e do que autoriza uma comunidade a ser reconhecida como quilombola e assim se identificar. As reflexões que aqui me proponho a fazer estão ancoradas na minha dissertação de mestrado e nas Diretrizes Curriculares Nacionais para a Educação Escolar Quilombola na educação Básica (BRASIL, 2012), que coloca mais um desafio aos sistemas educacionais, às escolas, aos professores, aos alunos e às comunidades quilombolas: pensar e construir uma escola que dê conta de atender as 
especificidades das comunidades quilombolas, evidenciadas a partir do reconhecimento legal dessas comunidades.

Desde o reconhecimento, apresentado no Ato das Disposições Constitucionais Transitórias, em seu Artigo 68 -, do direito à terra e à titulação aos herdeiros da resistência ao regime de escravidão no Brasil (BRASIL, 1988), o conceito de quilombo precisou ser ressignificado para que pudesse atender as especificidades das comunidades negras que reivindicam as terras onde vivem secularmente, tomando a identidade quilombola como estratégia de afirmação da ancestralidade e de visibilização de uma história intencionalmente ocultada por razões políticas, sociais, econômicas e culturais.

Neste trabalho, toma-se o processo de construção de identidade da comunidade negra quilombola de Mangal e Barro Vermelho, no Oeste da Bahia, como referência para refletir sobre o conceito de quilombo, ampliando a compreensão sobre essas comunidades, contribuindo para a desconstrução de preconceitos e favorecendo a convivência respeitosa entre as diversas culturas.

\section{Algumas considerações sobre quilombo e quilombo contemporâneo}

Tradicionalmente, quilombo designa esconderijo de negro fugido. De acordo com o parágrafo terceiro do regimento de 1724, por quilombo se devia entender “[...] toda habitação de negros fugidos que passe de cinco em parte despovoada ainda que não tenham ranchos levantados nem nela se achem pilões" (apud, LARA, 1996, p.43). O regimento de 1733, aprovado pela Câmara de São Paulo, apresenta outra definição de quilombo, sendo este "[...] o ajuntamento de mais de quatro escravos vindos em matos para viver neles e fazerem roubos e homicídios [...]" (apud, LARA, 1996, p.44). 
Observa-se que, no contexto da escravidão, o conceito de quilombo variou de acordo com a realidade de cada lugar, tendo como ponto de intersecção a fuga do regime, indicando o movimento que fez o conceito para se adequar às realidades e experiências naquele contexto, "tratando-se de uma definição operacional diretamente ligada ao estabelecimento dos salários do capitão-do-mato, mas que é, sobretudo, uma definição política" (LARA, 1996, p.97).

A Constituição Federal de 1988, com a conquista do Artigo 68, dos Atos das Disposições Constitucionais Transitórias - no qual afirma que aos remanescentes das comunidades dos quilombos que estejam ocupando suas terras, é reconhecida a propriedade definitiva, devendo o Estado emitir-lhes os títulos respectivos -, revela a necessidade de repensar o conceito de quilombo a partir da diversidade de comunidades negras.

Com essa preocupação a Associação Brasileira de Antropologia (ABA) atualizou o conceito de quilombo afirmando que,

Contemporaneamente, portanto, o termo quilombo não se refere a resíduos ou resquícios arqueológicos de ocupação temporal ou de comprovação biológica. Também não se trata de grupos isolados ou de uma população estritamente homogênea. Da mesma forma nem sempre foram constituídos a partir de movimentos insurrecionais ou rebelados, mas, sobretudo, consistem em grupos que desenvolveram práticas cotidianas de resistência na manutenção e reprodução de seus modos de vida característicos na consolidação de um território próprio. (O’DWYER, 1995, apud MOURA, G., 1999, p. 102 103).

No bojo da luta do Movimento Negro pela reparação social, especialmente a partir da promulgação da constituição de 1988, quilombo, uma categoria coletiva (VÉRAN, 1999 p.199) que estava no passado, é retomada, e seu conceito ganha novo sentido. O conceito de quilombo é, nesse momento, repensado e reconstruído politica- 
mente no jogo do poder, abrindo possibilidades para as populações negras rurais, historicamente marginalizadas, do direito ao reconhecimento de uma ancestralidade que lhes garantirão benefícios políticos e materiais.

Abordar a ressemantização do conceito de quilombo é importante porque só a partir daí é possível pensar em Mangal como quilombo, visto que as comunidades negras de Mangal e Barro Vermelho não aparecem na narrativa de seus moradores, nem em qualquer outro documento, como tendo sido quilombo a partir dos conceitos apresentados pela historiografia tradicional - como lugar de negro fugido. Mangal e Barro Vermelho têm todas as características daquilo que podemos denominar de Terra de Santo $^{1}$, como se pode evidenciar no depoimento do senhor Santos, I (2005) : “[...] a terra pá Santa quem deu foi uma mulher que tinha aqui que era de minha família [...].”

Diante desse cenário, no estudo dessa comunidade, a memória a ser valorizada não é se o grupo em questão tem ou não alguma relação com as formações que se encaixam na definição tradicional de quilombos, que tem em Palmares sua principal referência, outros elementos precisam ser considerados. Quilombo, nessa perspectiva, é o lugar da resistência, e resistência não se dá de uma mesma forma em territórios e contextos diferentes, muito menos entre sujeitos diferentes. Não reconhecer essa complexidade é desconsiderar a dialética das relações entre os sujeitos e seus contextos e entre si.

Fora dessa perspectiva, Mangal jamais poderia ser reconhecido como quilombo, pois mesmo o termo quilombola era desconhecido na Comunidade, como podemos observar na fala de Pereira (2005), um dos moradores: “[...] o senhor desculpa as minhas expressão, a minha ingnorança, o que... que é quilombo? Porque o quilombo que, que... que eu entendo é quilometrage, é midição”. A fala de Pereira(2005), diante do repre- 
IDENTIDADE QUILOMBOLA E EDUCAÇÃO ESCOLAR QUILOMBOLA: CONTRIBUIÇÕES A PARTIR DA EXPERIÊNCIA DE UM QUILOMBO

sentante do INCRA, em 1997, deixa claro que nem sempre se foi quilombola em Mangal/Barro Vermelho e, portanto, Mangal nem sempre foi quilombo a partir de uma concepção tradicional.

O modo como Mangal garantiu a sobrevivência dos elementos destacados por eles como fundantes na construção da identidade tem como cenário um pedaço de terra às margens do Rio São Francisco, que é o lugar onde se desenvolveram mitos, ritos, fazeres e saberes que, para eles, dão suporte à identidade do grupo ou à identidade de cada um, fazendo dele quilombo, compreendido como lugar de resistência e de transgressão.

Dessa forma, discutir o que é quilombo e identidade quilombola é uma necessidade política e pedagógica, especialmente a partir da aprovação das Diretrizes Curriculares Nacionais para a Educação Escolar Quilombola na Educação Básica (BRASIL, 2012), que tem provocado movimentos políticos e pedagógicos no interior dessas instituições escolares, muitas vezes por desconhecimento de seu significado histórico e de sua amplitude. Nesse sentido, contar a história de Mangal e Barro Vermelho contribui para fortalecer a compreensão do processo histórico de identificação e reconhecimento das diversas comunidades quilombolas presentes em nosso território.

Ressalte-se a necessidade de se tomar o cuidado para não pensar em quilombo no singular, o que equivale a dizer que, ainda que as histórias e modos de viver da comunidade de Mangal e Barro Vermelho se aproximem da história de outras comunidades quilombolas, cada história é uma história particular. Mas é exatamente porque, embora diversas, estas comunidades estão ligadas entre si pelo passado da escravidão, que determinou as condições atuais de suas existências, que a história do Mangal tornase uma referência para outras realidades.

Mangal reivindicou a identidade quilombola no bojo da luta pela terra, a qual, posteriormente, se desdobrou num processo de retomada de sua história e identidade. 
Foi assim que a comunidade em pouco mais de dois anos passou de mangazeira à quilombola ao ser reconhecida como "remanescente" de quilombo em 1998, inclusive pela consciência de que não se tornariam quilombolas se não fossem mangazeiros.

\section{Antes, “mangazeiros”, negros feiticeiros; hoje, quilombolas: ressignificando a identidade}

O povo do Mangal está arraigado naquelas terras, segundo a tradição oral, às margens do Rio São Francisco, no Município de Sítio do Mato-Estado da Bahia, desde o século XVIII, onde construíram a experiência histórica de se reproduzirem, de produzirem as condições de sua existência e de reproduzirem a cultura de seus ancestrais, nem sempre do mesmo jeito, mas no jogo da vivência e sobrevivência, conservando e/ou reformulando significados. Segundo os relatos orais, a comunidade surge a partir da escravaria de certo Capitão João, que teria se apaixonado por uma escrava e que, a pedido dela, teria doado a terra a Nossa Senhora do Rosário. Desde então, os negros da fazenda passaram a morar no Mangal, lugar onde se soltava o gado. Na negociação com seu entorno, durante muito tempo, a comunidade - de origem escrava e adepta a práticas religiosas de matriz africana -, negou sua crença, tomando a Nossa Senhora do Rosário como padroeira. Ser Mangazeiro era ser reconhecido pelo entorno como negros feiticeiros.

Muitas histórias à beira do Rio São Francisco foram construídas em torno do que chamo de hetero-identidade, pois eles eram reconhecidos pelo outro como mangazeiros, mas não se auto-reconheciam como tal. Nos anos 1990, a possibilidade de perda da terra, que lhes pertenciam legitimamente, mas não legalmente, possibilitou a esses negros e negras a (re)conhecerem suas histórias quando, mais uma vez, um outro 

CONTRIBUIÇÕES A PARTIR DA EXPERIÊNCIA DE UM QUILOMBO

lhes dizem que são, agora, quilombolas. A partir de então, a comunidade faz um movimento de retomada de suas histórias e, para se tornarem quilombolas, retomam e ressiginificam a identidade mangazeira. Assim, Mangazeiros, que até então não sabiam o que era quilombo, tornam-se quilombolas.

Um pressuposto que permeia a concepção de identidade nesta discussão é que esta é construída coletivamente, posto que é "um processo de duas vias em operação tanto no indivíduo quanto no grupo" (GIRAUDO, 1997, p.12). Embora a internalização dos elementos constituintes da identidade passe, necessariamente, por um processo de individuação, seria impossível a construção da identidade sem as marcas de uma experiência coletiva que religue o passado ao presente, principalmente porque,

Toda e qualquer identidade é construída. A principal questão, na verdade, diz respeito a, como, a partir de quê, por quem e para que isso acontece. A construção de identidades vale-se da matéria prima fornecida pela história, geografia, biologia, instituições produtivas e reprodutivas, pela memória coletiva e por fantasias pessoais, pelo aparato de poder e revelações de cunho religioso. (CASTELLS, 1999, p. 23).

A reflexão acerca da relação da Comunidade com a experiência da escravidão e da discriminação, a lida na terra e com a terra, bem como a luta por sua conquista, além de seus ritos e festejos, são os recortes priorizados na análise desse tecido.

O medo de falar da escravidão como forma de evitar com que esta se repita e o silêncio sobre a questão que desemboca na ignorância das gerações mais jovens sobre o assunto são evidências do quanto este tema é relevante para se pensar a identidade na comunidade. Mesmo porque, embora institucionalmente a escravidão tenha sido abolida no Brasil, em Mangal, em 2006, era atual o medo desta, como demonstra Pereira (2005, informação oral): “[...] fico procupado com essa geração, porque se num souber fazer..., a escravidão, ela pode tornar a vim; e, se ela vim agora, ela vem mais feia, porque 
ela num cabou, civilizou.” Uma referência explícita às condições de desigualdades, nas quais estão submetidos os negros.

A origem escrava da comunidade e, por conseguinte, sua afrodescendência, discriminada pela sociedade local, rendeu aos moradores a "pecha" "mangazeiro". Foi o entorno que assim os denominou de forma preconceituosa. Ser "mangazeiro", significava ser negro feiticeiro. A forma pejorativa como eram tratados pela vizinhança, durante muito tempo, fez com que os "mangazeiros" negassem sua origem. Vários relatos de moradores dão conta da visão que tinha a vizinhança em relação a eles, a exemplo do relato de Pereira (2005, informação oral), que diz que "[...] naquele tempo era a pobreza, nué? Era a pobreza, era uns negos, beiçudos, eram preguiçosos, era feiticeiro, entendeu? Só vinha aqui quem tinha negoço.”

Além da narrativa acima, o relato de Souza M.(2005, informação oral), a seguir, também evidencia o quanto a relação de Mangal com o seu entorno era marcada pela discriminação, embora tivesse que manter com este atividades comerciais que assegurassem a sobrevivência do grupo. "Porque até 1998 pa trás, nenhum rapaz do Mangal, aqui, chegava em Gamelêra, namorava uma moça. Chegava em Paratinga, namorava.”

A rejeição da vizinhança favoreceu o casamento endogâmico na Comunidade, o que contribuiu para que eles vivessem voltados para as relações internas e fortalecessem laços de solidariedade importantes na história deles como elemento de resistência. Por essa razão, a relação destes moradores com seu entorno era bastante restrita. Até mesmo o poder público desconsiderava a existência da Comunidade. "Eles vivia aqui isoladamente, parecia uns vereador aqui de quatro em quatro ano, pra pegar os voto. $\mathrm{E}$ eles: "voto, voto, voto, voto", entendeu? E aí, o galante sumia”, relata Pereira (2005, informação oral). É nesse contexto conflituoso e marcado por negociações com seu entorno que os mangazeiros construíram a sua (s) existência (s) e, por conseguinte, sua(s) identidade(s). 
Nesse sentido, a memória dos mais velhos teve papel relevante na transmissão e ressignificação de conhecimentos, saberes e valores que fizeram da Comunidade única, mesmo partilhando características gerais com outras comunidades negras rurais. A singularidade dela é construída na atualização da experiência que impossibilita a reprodução fiel do vivido que ganha sentido único no contexto em que se insere, posto que "atemporal, no mínimo, pode levar a cristalização de valores absolutamente extemporâneos em relação às características e demandas da contemporaneidade" (MATTOS, 2003, p.30).

O processo de construção das identidades nasce de situações reais de vida. No caso específico de Mangal, a luta pela conquista da terra é a luta de um grupo que vivenciou, por um longo tempo, uma história marcada pelo preconceito e pela possibilidade de expulsão de seu território, solo de origem onde estão enraizadas memórias e histórias relevantes para a Comunidade.

A terra para a comunidade de Mangal é território para além de espaço físico, é também espaço político no qual são implementadas ações e negociações que possibilitam ao grupo a manutenção de valores comunitários que, certamente, garantiram a sobrevivência do grupo em meio a todos os conflitos vividos. Nesse contexto, "O território aparece assim como um dado necessário à formação da identidade grupal/individual, ao reconhecimento de si por outros" (SODRÉ, 1999, p.15).

O modo peculiar com que a Comunidade ocupa a terra é um elemento de identificação e diferenciação desse espaço. Por ocasião do reconhecimento, o Instituto Nacional de Colonização e Reforma Agrária (INCRA) propunha que a comunidade em questão se organizasse de acordo com o padrão considerado para todos os assentamentos em área de reforma agrária. Nesse modelo, a divisão do território se daria por lotes individuais onde o cultivo da terra e a decisão do que plantar seriam uma prerrogativa individual. Tal proposta foi desconsiderada pelo grupo, que se recusou a 
lotear a terra nos moldes apresentados pelo INCRA. As primeiras habitações foram construídas às margens do Rio, próximas umas das outras. Eis duas referências importantes na observação do morar em Mangal.

O depoimento de Gomes (2005, informação oral) é bastante ilustrativo do que vem a ser o modo como a Comunidade se relaciona com o seu território: "a coletividade. Porque se não tivesse, nós tava igual os outros assentamentos. Cada um com seu pedacinho, cada um olhando pro seu umbigo. Nada de olhar pra ninguém”.

Da terra eles tiram o sustento desde os tempos em que a memória coletiva aponta como o marco da origem da Comunidade. Segundo essas memórias, o marco delimitador do tempo originário daquele povo em suas terras é o tempo do cativeiro, tempo do Capitão João. Desde aquela época, a prática por meio da qual esses indivíduos viabilizavam seu sustento era a lida na terra. Souza, C.(2005, informação oral) relata como os mais velhos tiravam o sustento, evidenciando a origem camponesa: “[...] $\mathrm{Na}$ roça e a inchada na mão, feijão de corda, feijão de arranca, milho, melencia, abóbora[...]."

A vazante ${ }^{2}$ sempre foi o lugar do plantio. A memória dos ancestrais também está enraizada no modo de produzir materialmente a vida. Ainda hoje, no Mangal, coexistem espaços coletivos e espaços privados. Praticamente não existem cercas no espaço interno de Mangal, a não ser as que delimitam a antiga sede da fazenda, hoje sede da Associação Agro-Pastoril Quilombola de Mangal/Barro Vermelho, transformada em espaço coletivo. Nem mesmo na vazante, onde cada família cultiva seu "pedacinho”, são verificadas cercas.

A luta por essa terra é, sem dúvida, o elemento principal na construção da identidade quilombola dos moradores do Mangal. Em 1997, quando os moradores do Mangal iniciam o confronto com o Grupo Aliança, com o intuito de conquistar a posse da terra, eles eram simplesmente os negros do Mangal. Alguns deles, hoje lideranças, como 

CONTRIBUIÇÕES A PARTIR DA EXPERIÊNCIA DE UM QUILOMBO

$\overline{\text { Pereira (2005), Gomes (2005) e Santos, D. (2005) (os dois primeiros já não moravam }}$ na comunidade há algum tempo) buscavam junto a outros trabalhadores reivindicar um pedaço de terra de onde pudessem tirar o sustento. A luta inicial foi por um pedaço de terra na fazenda Vale Verde.

A negativa desses trabalhadores em inseri-los na luta e a provocação de que eles tinham terra, os forçaram a se organizarem para conquistar a fazenda. Até então conquistar a terra não tinha relação direta com tornar-se quilombola. O depoimento de Santos, D.(2005,) esclarece bem o caminho e as razões de tornar-se quilombola no Mangal:

Eu tinha um colega que falava nesse negoço de quilombo, mas ele não explicava o que é que significava quilombo, isso era nessa faixa aí de 80 , por aí. Aí, eu fiquei pensando assim... quilombola... Só que ele disse que o processo ia ser lento, mas vale a pena. Eu disse: Rapaz, sei não!. Lá na hora da reunião também num dei opinião, fiquei quieto! (SANTOS, D, 2005, informação oral).

Se para conquistar a terra era preciso tornar-se quilombola, isso seria feito, embora os moradores não tivessem noção alguma do que viria a ser quilombo. Até mesmo a primeira professora da comunidade confessa sua ignorância sobre o tema: “[...] pra lhe dizer a verdade, eu num sabia nem o que era quilombo" (TEIXEIRA, 2005, informação oral). Entretanto, considerando que as identidades são políticas e atendem uma demanda da contemporaneidade, podemos afirmar que a identidade quilombola do Mangal é legítima. Foram as demandas concretas do contexto social, econômico, político e cultural, no qual estavam inseridos, que impulsionaram esses indivíduos a assumir e a negar uma identidade. Não se pode perder de vista que durante muito tempo, em função de uma outra demanda, os moradores do mangal rejeitaram ser "mangazeiros" e, por conseguinte, toda a carga histórico-cultural que dava significado ao termo: 
[...] quando eu viajei daqui pra Juazeiro mais minha mãe de vapor (pausa), ela me falou: "Se alguém perguntar de onde você é, você fala que é de Paratinga, não é do Mangal não, você não é do Mangal" Puxa! E eu nunca perguntei a ela o porquê, mais depois que eu vim saber porque era. [...] Porque dizia que o Mangal era feiticeiro, o povo era, tá entendendo? (GOMES, 2005, informação oral).

Tornar-se quilombola a partir de uma necessidade imediata para fazer valer um direito constitucional de acesso à terra é absolutamente coerente com os preceitos da modernidade. Nada mais é do que uma estratégia que garantirá o cumprimento de uma promessa. Nesse sentido,

a política de realização praticada pelos descendentes dos escravos exige, como fez Delany, que a sociedade civil burguesa cumpra as promessas de sua própria retórica. [...] Ela é imanente à modernidade e um elemento de seu contradiscurso valioso demais para ser sistematicamente ignorado. (GILROY, 2001, p. 96).

A identidade quilombola utilizada como instrumento para a posse da terra vai possibilitar a esses indivíduos repensarem, inclusive, a negação da identidade "mangazeira" e ressignificá-la, e o que antes era motivo de vergonha é, hoje, razão suficiente para se orgulhar:

Eu não gostava não, quando eu saía daqui pra outro lugar, eu não falava que eu era daqui. Aí, oh! Hoje eu tenho o maior orgulho de falar: olha! Eu sou do Mangal, sou de lá do quilombo, a terra dos negros. Eu tenho mesmo, muito, eu tenho, mas antigamente eu não gostava não. (SANTOS, G., 2005, informação oral).

Isso só é possível porque no plano prático a identidade quilombola devolveu àqueles negros não apenas a terra a que tinham direito, mas com ela veio a dignidade, a liberdade e o trabalho, elementos suficientes para que eles pudessem se colocar em pé de igualdade com o seu entorno, agora dentro de um espaço que, embora sempre 
tenham sentido como seu, não podiam, até então, usufruir.

Os benefícios trazidos pela nova condição de proprietários da terra caminham lado a lado com o orgulho de ser quilombola. É inegável que essa nova condição trouxe a esses indivíduos direitos que possivelmente jamais usufruiriam fora desta. Sair de 700 metros de terra - sem direito à caça, à pesca e ao plantio - para oito mil hectares de terra dos quais são proprietários, é motivo suficiente para que se incorpore uma identidade. A narrativa de Gomes (2005) nos mostra de forma significativa a transformação por que passaram esses indivíduos após o seu reconhecimento. O tempo agora é o tempo da liberdade, da alegria, da fartura, da independência:

É. Então era uma coisa... é triste. Agora não, estou alegre [...] você chega na casa de um (pausa) trabalhador. Cheguei na casa de Barriga, ele me deu um copo de vitamina (pausa)[...] Tem um velhim que chega assim e fala: - "chegava aqui no Mangal procurava um ovo pra cumer e não achava", tá entendendo? [...] não tinha condições da gente criar nada, né?. Então, o exemplo é esse que a gente hoje é... consquistemos nosso espaço. Nós tem hoje, né. Se eu quiser é... oferecer um bode, um carneiro pra você, pra gente amanhã almoçar, eu tenho condições de dar. Graças a Deus nós tem a nossa criação, né. (GOMES, 2005, informação oral).

Os elementos considerados pelo Laudo Antropológico, exigido pela Fundação Palmares a fim de reconhecimento da comunidade como remanescente de quilombo, sempre existiram na comunidade tais: sua constituição baseada em laços de parentesco; atividade produtiva concentrada quase que exclusivamente na agricultura familiar de subsistência e a criação de animais de pequeno porte; a memória do cativeiro; as festividades que trazem em sua memória de práticas que remetem a uma origem africana, como a Roda de São Gonçalo e a Marujada; a convivência entre espaços coletivos e particulares e um sentido muito forte e solidário de comunalidade. Sendo assim, o que os fazem diferentes face à nova realidade?

Cadernos de Pós-graduação, São Paulo, v. 17, n. 2, p. 35-54, jul./dez. 2018. 
A questão é que a partir da luta pelo reconhecimento, esses elementos ganham sentido enquanto arma política na construção de uma identidade. Então, "aquilo que é assim porque sempre foi",

Esses indivíduos são quilombolas porque assim se identificam, e o prestígio social dessa nova identidade faz com que assim sejam reconhecidos em seu entorno. É na junção dessas duas identificações - uma interna, outra externa - que eles, "mangazeiros", negros feiticeiros sem menor prestígio, se descobrem quilombolas. Descobrem-se mesmo, porque sua identidade foi soterrada pelo racismo institucional que negou, historicamente, as condições para sua afirmação. Esse diferencial está expresso de forma clara na narrativa que se segue:

A maioria, tudo quer ser parente dos mangazeiro. A gente não tem nada, mas temo ao meno o nome, né? E aí, aí, antigamente não. Ah! Ninguém quer ir no Mangal, não. Ninguém quer misturar com os nêgo do Mangal não. Ficava separado... Se é do Mangal e chegasse em Paratinga, algumas pessoas...! Chegava na Lapa do mesmo jeito. E hoje não, tá tudo muderno [...]. (ASSIS, 2005, informação oral)

Neste processo, a inexistência de políticas educacionais voltadas para a valorização da população negra no processo formativo da sociedade brasileira e, ainda pior, a inferiorização e até a criminalização da cultura afro-brasileira, passando por um "esquecimento, voluntário", do negro no espaço escolar, contribuíram fortemente para a construção de estereótipos visando à desvalorização do negro em nossa sociedade, causando prejuízos não apenas para os negros - as maiores vítimas nesse processo, mas também para os não-negros que, em função do racismo, do preconceito explícito ou simbólico, por afirmação ou por negação, perderam a oportunidade de construir uma relação, diferente da existente, com seus negros pares. 


\section{CONCLUSÃO}

Creio que a discussão sobre identidade quilombola em Mangal pode dar uma contribuição significativa para pensarmos identidade como categoria política, motivada pelas demandas do contexto em que estão inseridos os sujeitos. Esse exercício nos convida a alargarmos nossas concepções acerca do tema, valorizando os vários modos de construção de quilombos e quilombolas presentes na história das comunidades negras rurais que, bem mais do que as populações negras urbanas, ficaram invisíveis aos olhos da sociedade envolvente, impossibilitadas de contar suas histórias que, certamente, contribuiriam para enriquecer o debate sobre a história dos negros escravizados e seus descendentes na diáspora.

As histórias e as lutas das comunidades quilombolas são tantas quantas são estas comunidades. Quilombos que têm suas histórias enraizadas no confronto direto com a sociedade senhorial; quilombos que construíram sua resistência na negociação cotidiana com a sociedade escravistas; quilombos que se organizaram no pós-escravidão e mantiveram vivas as histórias e tradições de seus ancestrais; quilombos do campo, da cidade, os quais praticam cotidianamente quilombagem ${ }^{3}$.

Entretanto, se considerarmos que estas formas diferenciadas de resistência contribuíram, ao seu modo, para minar a sociedade senhorial - que não se encerra com o fim da escravidão -, podemos admitir que aí também se praticou a “quilombagem". As “Terras de Santo", a exemplo de Mangal, são o resultado de uma resistência negociada que transgride o princípio da sociedade escravagista na qual a prerrogativa da posse da terra era exclusividade do senhor. Nessa mesma direção, as diretrizes Curriculares Nacionais para a Educação Curricular Quilombola podem ser consideradas como uma expressão da quilombagem, visto que o fim do regime de escravidão não significou o 
fim do racismo e do preconceito racial no Brasil, outras lutas necessitaram e necessitam ser implementadas cotidianamente pela população negra em busca de equidade, igualdade e reconhecimento.

O esforço feito nesse trabalho foi no sentido de demonstrar que ampliar a compreensão do conceito de quilombo, com vistas a dar conta de articular um continuum entre as lutas contra a escravidão do Brasil, é necessária para atender, inclusive, as demandas por reparação social a que tem direito a população afro-brasileira. Os artigos 215 e 216 (Da Cultura), da Constituição Federal do Brasil, tornam legal o que já era de domínio popular ao reconhecer a contribuição dos negros na construção do patrimônio cultural da nação, além da garantia do exercício dos direitos culturais afro-brasileiros; entretanto, historicamente, os negros ficaram invisíveis na sociedade brasileira, apesar de sua maioria absoluta em termos quantitativos na população do país.

As Diretrizes Curriculares Nacionais para a Educação Escolar Quilombola na Educação Básica são mais um instrumento na luta contra o racismo, contra o preconceito, bem como por reparação histórica e social. Sua implementação é instrumento potencializador na construção de uma história diferente para a população brasileira e na construção de uma outra educação nos quilombos. Mas,para tanto, faz-se necessário a instrumentalização didático pedagógica de suas escolas, investir na formação dos professores que atuam nessas comunidades e, principalmente, criar as condições para a formação de quadros qualificados que estejam enraizados nos quilombos.

\section{REFERÊNCIAS}

ASSIS, Francisco de. (Chicão). Depoimento [janeiro, 2005]. Entrevistadora: Sandra Nivia Soares de Oliveira UEFS, 2005. Cassete sonor. Entrevista concedida à pesquisadora Sandra Nivia Soares de Oliveira. Sítio do Mato - Bahia, 2005.

BRASIL. Constituição (1988). Constituição da República Federativa do Brasil. Brasília, DF: 
Senado Federal: Centro Gráfico, 1988. 292 p.. Disponível em: < http://www.planalto.gov.br/ccivil 03/Constituicao/Constituicao.htm>. Acesso em: 25 jun. de 2015.

BRASIL, Ministério da Educação, Conselho Nacional de Educação, Câmara de Educação Básica.Rresolução no 8, de 20 de novembro de 2012. Define Diretrizes Curriculares Nacionais para a Educação Escolar Quilombola na Educação Básica.. Publicação no DOU n. ${ }^{\circ}$ 224, de 21.11.2012, Seção 1, página 26/30. Disponível em:

$<$ http://www.seppir.gov.br/portal-antigo/arquivos-pdf/diretrizes-curriculares $>$. Acesso em: 25 jun. de 2015.

CASTELLS, Manuel. O poder da Identidade: (a era da informação: economia, sociedade e cultura). São Paulo: Paz e Terra, 1999.

GILROY, Paul. O Atlântico Negro - Modernidade e Dupla Consciência. Rio de Janeiro, Editora 34/UCAM — Centro de Estudos Afro-Asiáticos, 2001.

GIRAUDO, José Eduardo Fernandes. Poética da Memória: uma leitura em Toni Morrison. Porto Alegre: ed. Universidade/UFRS, 1997.

GOMES, Carlos Alberto dos Santos. (Carlinhos). Depoimento [janeiro, 2005]. Entrevistadora: Sandra Nivia Soares de Oliveira UEFS, 2005. Cassete sonor. Entrevista concedida à pesquisadora Sandra Nivia Soares de Oliveira. Sítio do Mato - Bahia, 2005.

LARA, Silvia Hunold. Do singular ao plural: Palmares, capitães-do-mato e o governo dos escravos. In: REIS; GOMES (Org.). Liberdade por um fio: história dos quilombos no Brasil. São Paulo: Companhia das Letras, 1996.

MATTOS, Wilson Roberto de. Valores Civilizatórios Afro-Brasileiros na Elaboração de

Currículos Escolares - Ensaiando Pressupostos. In: RAMOS, Marise Nogueira, ADÃO, Jorge Manoel, BARROS, Maria Graciete Nascimento (Org.). Diversidade na educação: reflexões e experiências. Brasília: Secretaria de Educação Média e Tecnológica, 2003.

MOURA, Clóvis. A quilombagem como expressão de protesto radical, In: (Org.). Os Quilombos na dinâmica social do Brasil. Maceió: EDUFAL, 2001. 
MOURA, Glória. Os quilombos contemporâneos e a educação. In: Revista Humanidades. UnB Editora: Brasília: n. 47. p. 999-116, novembro, 1999.

PEREIRA, Egidio Gomes. (Senhorzinho). Depoimento [ janeiro, 2005]. Entrevistadora: Sandra Nivia Soares de Oliveira UEFS, 2005. Cassete sonor. Entrevista concedida à pesquisadora Sandra Nivia Soares de Oliveira. Sítio do Mato - Bahia, 2005.

SANTOS, Deraldo dos. (Caboje). Depoimento [janeiro, 2005]. Entrevistadora: Sandra Nivia Soares de Oliveira UEFS, 2005. Cassete sonor. Entrevista concedida à pesquisadora Sandra Nivia Soares de Oliveira. Sítio do Mato - Bahia, 2005.

SANTOS, Guilhermina Farias dos. Depoimento [ janeiro, 2005]. Entrevistadora: Sandra Nivia Soares de Oliveira UEFS, 2005. Cassete sonor. Entrevista concedida à pesquisadora Sandra Nivia Soares de Oliveira. Sítio do Mato - Bahia, 2005.

SANTOS, Isauro Lobo dos. Depoimento [ janeiro, 2005]. Entrevistadora: Sandra Nivia Soares de Oliveira UEFS, 2005. Cassete sonor. Entrevista concedida à pesquisadora Sandra Nivia Soares de Oliveira. Sítio do Mato - Bahia, 2005.

SODRÉ, Muniz. Claros e escuros: identidade, povo e mídia no Brasil. Rio de Janeiro: Vozes, 1999.

SOUZA, Clara Carvalho de. Depoimento [ janeiro, 2005]. Entrevistadora: Sandra Nivia Soares de Oliveira UEFS, 2005. Cassete sonor. Entrevista concedida à pesquisadora Sandra Nivia Soares de Oliveira. Sítio do Mato - Bahia, 2005.

SOUZA, Martinho Gomes de. Depoimento [janeiro, 2005]. Entrevistadora: Sandra Nivia Soares de Oliveira UEFS, 2005. Cassete sonor. Entrevista concedida à pesquisadora Sandra Nivia Soares de Oliveira. Sítio do Mato - Bahia, 2005.

TEIXEIRA, Cremilda de. Depoimento [janeiro, 2005]. Entrevistadora: Sandra Nivia Soares de Oliveira UEFS, 2005. Cassete sonor. Entrevista concedida à pesquisadora Sandra Nivia Soares de Oliveira. Sítio do Mato - Bahia, 2005.

VÉRAN, Jean-François. Rio das Rãs: Memória de uma "Comunidade Remanescente de quilombo" In: Revista Afro-Àsia, n. 23. Salvador: CEAO/EDUFBA, 1999.

\section{NOTAS:}


1 Terras de Santo ou Terras de Santíssima, que indicam uma territorialidade derivada da propriedade detida em mãos de ordens religiosas, da doação de terras para santos e do recebimento de terras em troca de serviços religiosos prestados a senhores de escravos por negros e negras, sacerdotes ou sacerdotisas de cultos religiosos afro-brasileiros.

2 Área fértil às margens do Rio São Francisco onde os moradores fazem sua roça.

${ }^{3}$ É um processo social contínuo de protesto que se desenvolve dentro da estrutura escravista, solapando-a histórica, econômica, étnica, e socialmente a partir de seu centro, isto é , a produção [...] um continuum que só termina com a abolição do sistema escravista colonial." (MOURA, C., 2001, p. 112).

recebido em 4 mar. 2018 / aprovado em 31 jul. 2018

\section{Para referenciar este texto:}

OLIVEIRA, S. N. S. Identidade quilombola e educação escolar quilombola: contribuições a partir da experiência de um quilombo. Cadernos de Pós-graduação, São Paulo, v. 17, n.2, p. 35-54, jul./dez. 2018. Disponível em: <https://doi.org/10.5585/cpg.v17n2.8429>. 


\title{
CURRÍculo MULTICULTURAL COMO INSTRUMENTO DE EMPODERAMENTO DE ESCOLAS QUILOMBOLAS
}

\section{MULTICULTURAL CURRICULUM AS AN INSTRUMENT FOR THE}

\section{EMPOWERMENT OF MAROON SCHOOLS}

\author{
Marcio Antonio Raiol dos Santos \\ Doutor em Educação pela Universidade Metodista de Piracicaba. \\ Professor Titular da Universidade Federal do Pará. Pará - PA - Brasil \\ marsraiol@gmail.com
}

\section{Carlos Afonso Ferreira dos Santos}

Graduando em Licenciatura em Educação Física pela Universidade Federal do Pará. Bolsista de Iniciação Científica do Programa Institucional de Bolsas de Iniciação Científica (PI-

BIC/UFPA EBTT). Pará - PA - Brasil afonso.fersantos@gmail.com

\begin{abstract}
Resumo: Este artigo apresenta uma discussão sobre o currículo multicultural e sua potencialidade como fator de empoderamento dos sujeitos que constroem a educação quilombola; caracteriza-se como pesquisa de cunho teórico; objetiva discutir noções interligadas sobre o empoderamento, a Educação Escolar Quilombola e o currículo multicultural; expõe a necessidade dos sujeitos envolvidos com a Educação Escolar Quilombola organizarem-se em prol de construções pedagógicas que vislumbrem aspectos históricos, políticos e culturais das comunidades em detrimento de um currículo prescritivo-oficial e, por fim, conclui que o empoderamento se apresenta como atitude mediadora das ações dos grupos com vista à sua autonomia e que o currículo multicultural manifesta-se como um instrumento de fortalecimento no contexto educacional dos quilombos.
\end{abstract}

Palavras-chave: Empoderamento. Educação Quilombola. Currículo multicultural.

Cadernos de Pós-graduação, São Paulo, v. 17, n. 2, p. 55-74, jul./dez. 2018. 
Abstract: This article presents a discussion about a multicultural curriculum, and its potential as a tool of empowerment of the subjects that compile maroon education. This is a theoretical research, with the objective of discussing interconnected notions about empowerment, Maroon School Education and a multicultural curriculum. The study exposes the necessity of the subjects involved with the Maroon School Education to organize themselves in favor of pedagogical constructions that glimpse historical, political and cultural aspects of the communities that are in danger due to a official curriculum. In conclusion, the empowerment presents itself as a mediating attitude of the actions of the groups with a view to their autonomy and that, therefore, a multicultural curriculum manifests itself as a strengthening instrument in the educational context of the maroons.

Key-words: Empowerment. Maroon Education. Multicultural curriculum.

\section{Introdução}

$\mathrm{U}$

ma das marcas históricas da sociedade brasileira é a distinção entre classes e grupos sociais. Introduzir esse entendimento apresenta um efeito no modo de explorar os sentidos e significados marcados pelos discursos sociais evidenciados nos espaços de convivência humana. Do campo educacional esses discursos valorizam grupos culturais específicos ou colocam-nos à margem.

Este artigo, traz diálogos sobre os processos social nos espaços dos quilombos, pretende discutir noções ligadas às especificidades do processo educacional em seu teor político abarcado pela consequente noção de poder. De tal modo, possui como objeto o currículo enquanto canalizador da prática educativa entendido como elemento de seleção particular da cultura (SACRISTÁN, 2000) numa perspectiva multicultural, a qual expressa uma potencialidade educacional com vista ao empoderamento de comunidades educacionais quilombolas.

Em decorrência desse fato, encontramos no currículo o sentido que expressa um terreno de produção e política cultural por considerar, a partir de uma perspectiva crítica, a cultura como uma expressão simbólica não unitária e não homogênea, mas sim um terreno de numerosos conflitos entre diferentes concepções de vida social 
(MOREIRA; TADEU, 2011). Dialogando com os autores no debate aqui materializado, encontramos o cerne da discussão: considerar o currículo educacional como campo mediador de tais conflitos.

Para tanto, objetivamos teórica e conceitualmente discutir noções que interligam perspectivas sobre o empoderamento, a Educação Escolar Quilombola e o currículo educacional de caráter multicultural. As proposições discutidas expressam a essencialidade de vislumbrar o espaço dos quilombos como terreno de produção cultural embasado por questões de poder.

\section{Empoderamento: história e conceitos}

Comunidades e grupos sociais constantemente vêm sendo produtores de lutas em prol de interesses próprios inerentes a seus desejos e projetos de vida social. Nessa esfera, pensar em luta é pensar em poder, sendo este um instrumento congregador de um teor político-social que marca a história de vida de grupos e comunidades em busca de condições de vida adequadas às suas realidades. Um dos termos propiciadores de um conjunto de ideias sobre práticas humanas em relações sociais imbricadas às relações de poder certamente é o empoderamento.

Uma retomada histórica nos mostra, conforme Hermany e Costa (2009), que a primeira ideia sobre o empoderamento tem suas raízes nos desdobramentos advindos da Reforma Protestante iniciada por Lutero na Europa durante o século XVI. A origem dessa noção, embora não tenha sido estabelecido um conceito sobre o termo (o que viria a acontecer séculos mais tarde), é revelada por um contexto que expressa um sentimento popular contrário às ações da Igreja Católica, que com seu autoritarismo político e religioso fez surgir uma atitude proativa da população na busca por justiça social. 
A notoriedade do conceito se deu na década de 1960 numa ação de eclosão de movimentos sociais, a exemplo do movimento negro contra o sistema de opressão nos Estados Unidos, passando a surgir o termo "empowerment" como sinônimo de emancipação social num processo de elevação da autoestima dos grupos oprimidos (HERMANY; COSTA, 2009).

Atribuída por Freire e Shor (1986), o termo “empowerment” surge, portanto, com o significado de "dar poder". Esse conceito nos permite uma específica análise do termo na sua tradução original, que no Brasil passa a ser traduzido de modo a se estabelecer um duplo sentido à palavra "empoderamento": para adquirir crescimento e autonomia o impulsionamento de grupos ou comunidades e, ao mesmo tempo, para promover ações com a intenção de integrar populações carentes e excluídas (GOHN, 2004).

Em relação à tradução do vocábulo na língua em que surgiu, Stotz e Araújo (2004) destacam que preferem apontar o termo ligado a sua marca de origem, o liberalismo civil e religioso, e nos apresentam sentidos atribuídos ao verbo "empower", como autorizar, permitir ou habilitar, sendo este último uma espécie de capacitação, no sentido de que se realize um processo de transferência de algo a alguém. Tal tradução, porém, é rejeitada pelos autores, pois expressa a ideia de que o poder é algo transferível.

Acerca disso, notam-se, formas de utilizações do termo sob a diferenciação entre os verbos transitivo e intransitivo. Assim, no contexto da transitividade verbal, empoderar significa "dar poder a outro", com base no pressuposto de que existem indivíduos ou grupos desempoderados com a necessidade de ações que possibilitem o acesso ao poder por meio de outro grupo em condição de mais elevado poder. Desta forma, essa condição apenas reforça a ação de submissão de um indivíduo ou grupo em relação ao outro, no sentido de serem incapazes de deterem o poder por conta própria (BAQUERO, 2012). 
A utilização do termo a partir do verbo intransitivo, por sua vez, revela que a ação de empoderar envolve não dar o poder a alguém, mas, opostamente, tornar esse alguém ou grupo capaz de obter poder de forma autônoma (BAQUERO, 2012). Freire e Shor (1986), enfatizam que o "dar poder" oferece um entendimento de que se ative, se desenvolva e se dinamize a potencialidade criativa do sujeito de modo que tais atitudes deem sentido às suas ações.

A discussão permeada pela associação entre poder ligada à dominação e à emancipação (BAQUERO, 2012) expressa o entendimento de que, historicamente, se deram em relações sociais práticas que manifestavam a correspondência de dominação de um grupo sobre outro, ao passo que o grupo dominado, aja de modo a buscar sua emancipação e maior capacidade de participação (GOHN, 2004; HOROCHOVSKI; MEIRELLES, 2007; KLEBA, 2009; HERMANY; COSTA, 2009). Esse viés explana ações históricas do conceito de “empowerment" ligadas ao alcance ao poder de forma individual ou coletiva.

Quanto ao nível individual, trazemos o diálogo entre Freire e Shor (1986) e Zimmerman (2000). Em uma perspectiva de empoderamento individual, Freire e Shor destacam que tal noção, expressada na sociedade norte-americana da década de 60, evidencia noções individuais de progresso, visto que a busca pela autonomia se deu de tal modo que se privilegiasse o individualismo ou, como expressa Baquero (2012, p.177), o self made man, "o indivíduo que se faz pelo seu próprio esforço pessoal".

Em compreensão semelhante, Zimmerman (2000) expressa que o empoderamento individual, refere-se à competência do indivíduo em exercer controle pessoal sobre suas ações, bem como compreender criticamente, sua situação política e social. Todavia, embora se infira que o empoderamento individual preze por ações independentes do indivíduo, uma vez que "pode ocorrer sem que haja necessidade de que as 
pessoas participem de ações políticas coletivas" (CARVALHO, 2004, p.1090), é necessário um processo de integração com a comunidade (KLEBA, 2009), visto toda ação autônoma requerer engajamento e reconhecimento do ambiente onde tal indivíduo vive, o que Zimmerman (2000) elenca como componente comportamental do empoderamento individual.

Por sua vez, o empoderamento coletivo ou grupal, importante conceito para o entendimento das reflexões posteriores, refere-se ao processo de busca por condições satisfatórias de vida que sejam de interesse de grupos específicos, quase sempre estruturalmente desprivilegiados ou em situação subalterna. Horochovski e Meirelles (2007) apontam ser um artifício pelo qual os sujeitos envolvidos, por intermédio de processos participativos, buscam construir estratégias que visem ao alcance de objetivos traçados de comum acordo, mesmo que em uma comunidade existam diferentes interesses.

Ratificamos que, na busca por resultados que privilegiem uma garantia de satisfação de vida (e, nesse sentido, o empoderamento), é necessária uma sociedade ativa (HERMANY; COSTA, 2009) que se empenha em prol do acesso aos bens e aos recursos que lhe deem oportunidade de fortalecer-se, bem como de possuir autonomia. Logo, necessita-se a busca por uma atitude organizacional, pois, como já frisado, indivíduos devem a partir dela organizarem-se coletivamente na busca pelo poder, em virtude de o mesmo não existir a priori em determinadas comunidades. (GOHN, 2004).

Considerando que a noção de empoderamento surge paralelamente às resultantes da noção de poder que, conforme Carvalho (2004), é distribuído de forma desigual na sociedade, podemos considerar que esse processo inclui, de maneira especial, segundo o autor, a remoção de barreiras que limitam a vida de uma comunidade, bem como a legitimação de sua voz, de modo a adquirir controle sobre sua vida, maior justiça social e melhoria na qualidade de vida (CARVALHO, 2004). A ação de dar voz, 
nessa esfera, exprime a busca dessas comunidades por condições iguais de vida social a partir de processos de reflexão coletiva sobre a situação que ocupam.

Assim, neste artigo defendemos o empoderamento como aspecto histórico e necessário a grupos que ensejam autonomia e perspectivas satisfatórias de vida com base em ações que legitimem vozes antes desprivilegiadas e à margem do poder. Ademais, podemos atribuir a essa ação atitudes coletivas de organização, haja vista a busca pelo poder requerer o vislumbre a capacidade de elos entre os pertencentes de uma comunidade.

A discussão a seguir toma como referência o olhar relacionado ao empoderamento como aspecto importante à educação e ao modo de vida de comunidades quilombolas. Por meio das considerações supracitadas, tais comunidades enquadram-se em condições opostas a grupos considerados hegemônicos e detentores do poder.

\section{Educação Quilombola na contemporaneidade}

Pensar a comunidade quilombola nos processos constituintes da noção de poder é tarefa relevante, tanto pelas perspectivas que revelam o modo de vida atual de tais comunidades, quanto pelo entendimento acerca de sua constituição política, social e, sobretudo, educacional em um espaço que historicamente revela-se um espaço de resistência (NASCIMENTO, 2009). Discuti-la, portanto, remete à explanação de sua perspectiva histórica escravocrata.

Assim, temos, por volta de 1500, conforme Nascimento (2009), a figura do africano escravizado como primeiro trabalhador, juntamente aos índios, no decurso de três séculos e meio, a erguer as estruturas do Brasil. Apesar disso, o negro nunca fora tratado como igual pelos minoritários brancos detentores do poder. Reflexo disso é o nascimento dos quilombos como local que explicita a sobrevivência e a existência do 
CurRíCulo MUlTiCUltural COMO INSTRUMENTO DE EMPODERAMENTO DE ESCOLAS

QUILOMBOLAS

$\overline{\text { negro, tendo em vista sua liberdade e dignidade mediante a fuga do cativeiro no qual }}$ era mantido e a organização de uma sociedade livre, entendida, conforme o autor, como foco de resistência física e cultural e espaço de movimento autêntico, amplo e permanente. Os quilombos passam a surgir, portanto, sob a representação de um ambiente improvisado de emergência que proporcionou a "constante vivência dos descendentes de africanos que se recusavam à submissão, à exploração e à violência do sistema escravista." (NASCIMENTO, 2009 p.203).

Atualmente, vimos um processo de manutenção desses espaços de resistência em localidades geralmente rurais do país, habitadas por descendentes de africanos. Nesse seguimento, ao conceituar esses espaços como quilombos contemporâneos, Moura (2007) discorre sobre comunidades negras localizadas em espaços rurais - terras doadas, compradas ou ocupadas secularmente pelo grupo que ali habita -, resididos por descendentes de africanos escravizados para garantir a manutenção de laços de parentesco.

Nesse sentido, a discussão sobre o empoderamento é expressa em relação às formas de organização dessas comunidades concernentes aos aspectos de suas condições físicas e estruturais quanto ao afastamento dos grandes centros e às dificuldades de infraestrutura e comunicação, além de questões fundamentais apontadas por Lopes (2007) e por Gomes (2007), como as que abrangem a saúde, o transporte, o desenvolvimento sustentável e, sobretudo, a educação. De acordo com as autoras, tais questões não devem deixar de ser discutidas acima de tudo na pauta das políticas públicas, pois, conforme sua colocação, entendemos que o quilombo é um espaço reflexo de uma perspectiva histórica de marginalização e negação de direitos essenciais. Essa situação resulta no seu enquadramento à condição de "a margem", mas pode ser diminuída em função da participação coletiva em prol de ações que visem ao bem comum e à autonomia sobre seu futuro.

Cadernos de Pós-graduação, São Paulo, v. 17, n. 2, p. 55-74, jul./dez. 2018. 
Do ponto de vista educacional, as concepções a serem consideradas na busca de parâmetros reais que entendam a educação quilombola atual consideraram condições de espaço, pois o isolamento geográfico dessas comunidades acarretam dificuldades acerca da disponibilidade docente em tais espaços educacionais e das condições de assistência, visto que o poder público não oferece atendimento ao quilombo e às escolas ali inseridas.

Acerca dessas concepções, consideramos que a própria estrutura organizacional evidenciada pelos atores escolares na educação quilombola deva contemplar uma construção coletiva que dê conta das demandas educacionais ao perpassar por questões que envolvam uma organização com ênfase no processo educativo concomitante ao reconhecimento da cultura local da comunidade (LARCHERT; OLIVEIRA, 2013) e, ao mesmo tempo, atendam ao processo de ensino e aprendizagem ligado à realidade cultural, social e histórica vivida nesses espaços e enveredado pela problematização do currículo como elemento que fundamente e direcione a educação nesse espaço.

Para tanto, a escola quilombola, assim como a formal, deve ser capaz de demandas previstas na legislação com vista a sua altivez. Nessa lógica, situamos as determinações acerca das Diretrizes Curriculares Nacionais para a Educação Escolar Quilombola na Educação Básica, que estabelece a educação ministrada na referida instituição educacional, com ênfase na organização do ensino de modo a dar conta de conteúdos que expressem o patrimônio cultural das comunidades quilombolas de todo o país (BRASIL, 2012), tais como: territorialidade; memória coletiva; marcos civilizatórios; línguas reminiscentes; práticas culturais; tecnologias e formas de produção; acervos e repertórios orais e festejos.

Nesse seguimento, essa mesma educação é amparada por princípios que reconhecem, em meio a outras, as práticas político-pedagógicas que visem ao respeito e ao reconhecimento da história e da cultura afro-brasileira, à proteção das manifestações 
dessas culturas, à valorização da diversidade étnico racial, bem como à superação do racismo e à eliminação de qualquer forma de preconceito e discriminação racial. Esses princípios devem ser garantidos pela articulação entre um currículo aberto e flexível de caráter interdisciplinar, o projeto político pedagógico, assim como pela Lei $\mathrm{n}^{\circ}$ 10.639/2003 (BRASIL, 2012).

Sobre a Lei $\mathrm{n}^{\circ}$ 10.639/2003 (BRASIL, 2003), notamos a premissa do trabalho com aspectos que centram a obrigatoriedade do ensino na História e Cultura AfroBrasileira, como tratada nas Diretrizes para a Educação Quilombola, pois uma escola que se reconheça como tal, mais do que as demais escolas formais, possui o direito de trabalhar tal lei sob a prerrogativa de se apresentar em uma proximidade cultural mais contundente em relação à Cultura Afro-Brasileira.

Tais princípios que norteiam a elaboração da prática escolar quilombola congregam em direção à construção de um quadro que destaque a desvinculação, conforme apontam Oliveira e Martins (2014), entre uma educação escolar especificamente quilombola e a educação dita formal e regular, pois os modos de se encarar tais realidades são distintos quanto às práticas pedagógicas ali privilegiadas. Assim, questões étnicas, raciais, culturais, históricas, políticas, sendo estas imprescindíveis ao trato em uma esfera educacional situada de forma orgânica nesses espaços diferenciados, obrigatoriamente formam a base explícita dos saberes que deverão ser privilegiados no currículo pedagógico destas comunidades, de tal modo que pelo apoio às diretrizes norteadores da prática escolar quilombola, bem como pela Lei no $10.639 / 2003$, os conteúdos inseridos possam se ater a perspectivas que levem educadores e educandos localizados nessas comunidades a se reconhecerem como tal pela inserção em um espaço educativo que fomente uma construção identitária inerente às suas histórias de vida. 


\section{O currículo multicultural como instrumento norteador do empoderamento nos espaços educacionais quilombolas}

As reflexões sobre a educação quilombola, como vimos, fazem jus às noções preexistentes do conceito de poder pela busca de um tratamento linear que abrange, de um lado, a possibilidade de entendimento de uma realidade do ponto de vista macro, que compreende sua luta histórica imbricada à busca pela autonomia política, cultural e social e, de outro, a relação entre essa luta designada comunitária e seus desdobramentos em outros setores da vida social dessa dada realidade, a exemplo da própria educação.

Ressaltar a educação nesse panorama nos remete à necessidade de pensá-la como elemento integrante da prática social de toda e qualquer realidade, pois a escola, enquanto instituição social inserida em lócus que expressa marcas e ações da atividade histórica humana, necessita refletir, a partir da sua prática, sobre elementos que remetem à essência do conhecimento historicamente construído. Nesse viés, o currículo se torna o elemento central correspondente à organização desse conhecimento pela vinculação que compreende a relação entre práxis educativa e social.

A partir disso, é importante situar que toda e qualquer prática social é determinada pela participação de sujeitos. Entre essa prática e a educativa, portanto, está um currículo que forma sujeitos para atuarem democraticamente em práticas de diferentes setores da vida social, pois, como expressa Santomé (1995), uma das finalidades da intervenção curricular é preparar sujeitos que exerçam cidadania crítica e sejam solidários e democráticos em uma sociedade igualmente solidária e democrática.

Certo de que a proposição de um currículo nessa esfera expressa tais finalidades, a principal demonstração efetiva de que a organização curricular certamente contribui para a formação de sujeitos está atrelada a seu caráter identitário (SILVA, 2005), pois é 
$\overline{\text { pelo currículo que nos tornamos o que somos e, a depender de sua finalidade, estamos }}$ diante de um projeto educacional que aponta para elementos essenciais à criação de uma estrutura congregadora de aspectos formativos para participação em comunidade.

Entretanto, há de se esperar que a organização dos saberes expressos em um currículo não se dê de forma desinteressada (BRASIL, 2013 p. 441). Aspira-se, opostamente, a organização de um currículo construído de forma coletiva que manifeste o fortalecimento de uma comunidade educacional e seja um instrumento coletivo de empoderamento por intermédio de um projeto que contemple os aspectos históricos, os valores, as experiências e a diversidade de específicas realidades, entre as quais se destaca a quilombola, de modo a lutar contra a reprodução dos fenômenos de marginalização (SANTOMÉ, 1995) e agir ativamente contra situações opressivas da sociedade contemporânea.

Para isso, tomando como referência as unidades educativas quilombolas, todos os envolvidos necessitam discutir propostas pedagógicas que, por meio de um processo de participação, possam colocar em questionamento as possibilidades de concepções curriculares apropriadas à constituição de um ambiente que amplie a aprendizagem (BRASIL, 2007) e, em um sentido mais amplo, propicie um ambiente que reflita questões intrínsecas à realidade de dada comunidade pela proposição de conteńdos culturais (SANTOMÉ, 1995), sobretudo a partir de práticas pedagógicas pautadas em um currículo multiculturalista (CANDAU, 2008).

Em um aspecto quantitativo, a necessidade de diálogo acerca de tais propostas com foco na organização dos conhecimentos acessados pelos sujeitos atendidos pela educação quilombola se torna essencial. Ao realizarmos um levantamento das unidades escolares quilombolas no país, descobrimos que totalizam 2.369 instituições de ensino, segundo dados estatísticos do Censo Escolar da Educação Básica de 2016 (BRASIL, 
2017) e que o do número de matrículas realizadas nessas escolas, conforme o mesmo Censo, foi de 241.925 no ano em questão.

A partir disso, tendo como meta a fortificação de uma comunidade escolar quilombola, os sujeitos envolvidos no processo de construção curricular necessitam ter em vista, inicialmente, a criação de um currículo dinâmico e flexível que dê conta das demandas escolares pela expressão de um projeto que permita ligações pertinentes aos direcionamentos apontados pelas diretrizes visando a uma ação maior que vislumbra o processo de ensino e aprendizagem pelo desvelar da apropriação dos saberes universais interligados aos locais com ênfase no estudo da realidade quilombola de forma aprofundada, ética e contextualizada (BRASIL, 2013). Para tanto, retomando a ideia do empoderamento propriamente comunitário, destacamos que:

[...] faz-se necessário abrir espaços, (...)para maior participação da comunidade e dos movimentos sociais e construir outras formas de participação coletiva e de consulta, nas quais docentes, gestores, pedagogos e estudantes dialoguem com as lideranças quilombolas, pessoas da comunidade, anciãos e anciãs e educadores quilombolas. Um currículo flexível e aberto só poderá ser construído se a flexibilidade e a abertura forem, realmente, as formas adotadas na relação estabelecida entre a instituição escolar e a comunidade (BRASIL, 2013 p.442).

Assim, tendo como base a projeção de um currículo nessa esfera, uma possibilidade em potencial é pela proposição, a partir de uma concepção pós-crítica (SILVA, 2005), de um currículo multicultural, uma vez que um projeto de multiculturalismo, conforme apontam Canen e Oliveira (2002), se insere em um projeto pós-moderno de sociedade, onde se potencializa a análise da diversidade, bem como da diferença.

Um projeto de currículo multiculturalista na Educação Escolar Quilombola se expressa pelos vieses que abrangem a educação como uma prática imersa e situada em processos culturais (CANDAU, 2008). Esta evidência, segundo a autora, se situa em 
um aspecto que revela a importância de não se ignorar questões culturais dentro da escola e propor rompimentos com seu caráter homogeneizador e monocultural em direção à construção de práticas curriculares de questões que englobem a diferença e o multiculturalismo.

A educação quilombola se encaixa em um projeto multicultural, pois seu trato educacional exprime o trato com outros aspectos que envolvem história, cultura e sociedade, todos imersos em lócus específicos de cada realidade. Um projeto de currículo multiculturalista em situação de vida quilombola resgata perspectivas históricas que situam, por sua vez, a formação histórica de forte base multicultural e a relação entre etnias no país em que vivemos, onde grupos considerados marginalizados sofreram dolorosa e tragicamente diante os processos históricos da vida social (CANDAU, 2008). O resgate de tais perspectivas exprime, portanto, a reinvindicação de um currículo anti-marginalização de efeito emancipador (SANTOMÉ, 1995).

Ao defendermos possibilidades em potencial relacionadas a um projeto curricular direcionado à Educação Escolar Quilombola, vislumbramos a construção coletiva de um projeto curricular pelos diversos sujeitos envolvidos nessa educação e, sobretudo, um currículo que extrapole uma reprodução exclusiva de uma proposta curricular externa, imposta por uma rede de ensino que não seja construída pela comunidade escolar quilombola, haja vista tal proposta, por intermédio de um currículo prescritivo (SACRISTÁN, 2000), portanto oficial, ordenar conteúdos ligados quase sempre a uma monocultura nacional (APPLE, 2011b). Considerando que a Educação Escolar Quilombola se situa como uma modalidade de ensino específica ao trato com a história e a cultura quilombola (BRASIL, 1996) além dos conhecimentos mais gerais, a perspectiva de construção curricular se baseia em um agir autônomo, que leve em conta a decisão sobre os conhecimentos que desse grupo serão priorizados, revelando uma concepção de poder (SILVA, 2005) atribuído ao currículo. 
Nessa esfera, cabe citar a importante contribuição de Apple (2011a). O autor aponta que quem decide e define o tipo de conhecimento expresso no currículo é justamente quem detém o poder na sociedade, e por conseguinte tais grupos hegemônicos privilegiam sua visão de mundo em detrimento da visão de mundo dos grupos subalternos, ou seja, sua história, cultura, estética e ciência são excluídas dos currículos oficiais.

A construção autônoma de um tipo de projeto escolar a partir um ponto de vista empoderador expressa, nessa perspectiva, o poder que comunidades escolares quilombolas têm na organização de seus espaços, de suas atividades educacionais e, especialmente, da escolha coletiva sobre os saberes privilegiados no currículo quilombola, de modo que não se permita vir à tona aspectos de um currículo estático, disciplinar, segmentado, que separe alta e baixa cultura (SILVA, 2005). De tal modo, o ponto de vista do empoderamento aliado ao elemento curricular expressa uma relação de causa e efeito, conforme mostra a figura abaixo:

Figura 1 - relação de causa e efeito atribuída ao empoderamento escolar quilombola.

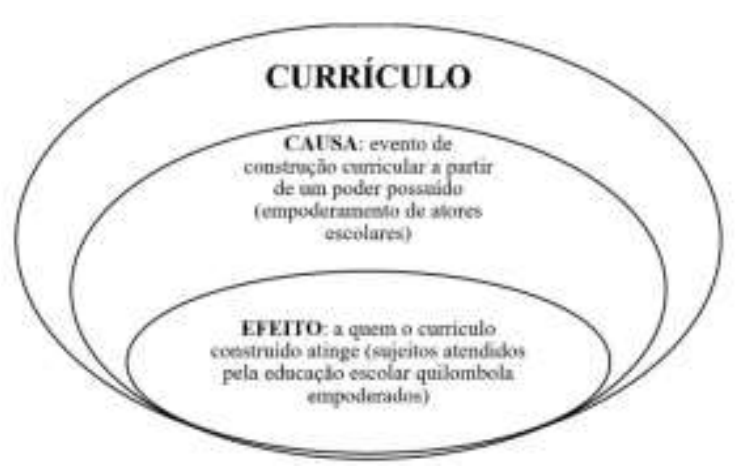

Fonte: Autores 
O empoderamento na tônica dessa discussão ganha, portanto, mais um sentido prático: fortalecer comunidades escolares que, em um sentido amplo e compromissado com sua história, possam levar em conta seus interesses na construção de projetos educacionais inerentes a seus fins sociais e educativos (causa-Figura 1) por intermédio do elemento curricular como um instrumento necessário de fortalecimento escolar e comunitário, sobretudo em relação ao fim a que se destina. Isto é, a ação empoderadora dos sujeitos atendidos pela educação quilombola (efeito-Figura 1).

A discussão privilegiada nesta seção nos permite tecer considerações sobre perspectivas pedagógicas que vislumbrem uma concepção multiculturalista como base para a construção curricular de escolas quilombolas. Salienta-se que essa concepção possui sua relevância especialmente direcionada à organização dos conteúdos que expressam conhecimentos de cunho quilombola, a partir da qual se permite vislumbrar questões que manifestam os aspectos identitários dessa cultura no país e o consequente empoderamento dos sujeitos.

\section{Considerações finais}

O sentido de comunidade empoderada na discussão levantada no presente artigo toma como elemento as devidas relações quantitativas apresentadas quanto ao número que se aproxima de 2400 unidades de ensino quilombolas e 240 mil alunos matriculados na rede que revela um percentual relevante de sujeitos nessa modalidade de ensino que necessitam ser vistos, democraticamente, como cidadãos com direito a uma educação de qualidade.

Verificamos que a educação quilombola precisa ser tratada de forma específica a partir de seu resgate histórico de comunidade marcada por lutas e resistências. Quanto a esse aspecto, visualizamos a compreensão da educação como elemento integrante da 
prática social de toda realidade e a necessidade de seu empoderamento. Assim, o empoderamento necessita ser refletido em uma construção pedagógica fundamental para a escola, que é o currículo.

$\mathrm{Na}$ educação quilombola, uma potencialidade em vista é o currículo multicultural que, ao respeitar os saberes do currículo maior, também dá conta de conhecimentos locais da cultura do quilombo, a exemplo dos propostos pelas diretrizes quilombolas (as práticas culturais, a memória coletiva, as tradições da cultura quilombola, entre outros), com ênfase em uma formação que dê voz aos sujeitos e proporcione uma formação ligada à sua própria identidade.

Assim, o currículo como canalizador das práticas educativas pode, por consequência, ser o intermediador das ações que levam ao empoderamento dos sujeitos envolvidos com a Educação Escolar Quilombola, caso privilegie uma construção coletiva organizada.

\section{Referências}

APPLE, M. W. Repensando ideologia e currículo. In: MOREIRA, A. F; SILVA, T. T. (Org.). Currículo, cultura e sociedade. 12. ed. São Paulo: Cortez, 2011a.

APPLE, M. W. A política do conhecimento oficial: faz sentido a ideia de um currículo nacional? In: MOREIRA, A. F; SILVA, T. T. (Org.). Currículo, cultura e sociedade. 12. ed. São Paulo: Cortez, 2011b.

BAQUERO, R. V. A. Empoderamento: instrumento de emancipação social? - uma discussão conceitual. Revista Debates, Porto Alegre, v. 6, n. 1, p. 173-187, 2012.

BRASIL. Ministério da Educação. Indagações sobre currículo: diversidade e currículo. Brasília: MEC, SEB, 2007. Disponível em: < http://portal.mec.gov.br/seb/arquivos/pdf/Ensfund/indag4.pdf>. Acesso em: 19 out. 2018. 
QUILOMBOLAS

CuRríCulo MUlticultural COMO INSTRUMENTO DE EMPODERAMENTO DE ESCOLAS

BRASIL. Ministério da Educação. Diretrizes Curriculares Nacionais para a Educação Escolar Quilombola na Educação Básica. Brasília, 2012. Disponível em: <http:/ / por-

tal.mec.gov.br/index.php?option $=$ com_docman\&view $=$ download\&alias $=11963$ rceb008-12-pdf\&category_slug=novembro-2012-pdf\&Itemid=30192>. Acesso em: 19 out. 2018.

BRASIL. Ministério da Educação. Diretrizes Curriculares Nacionais para a Educação Escolar Quilombola. In: BRASIL, Ministério da Educação. Diretriz̧es Curriculares Nacionais Gerais da Educação Básica. Brasília: MEC, SEB, DICEI, 2013.

BRASIL. Ministério da Educação. Censo Escolar da Educação Básica 2016: Notas Estatísticas. Brasília, 2017. Disponível em: < http://download.inep.gov.br/educacao_basica/censo_escolar/notas_estatisticas/2017/notas_estatisticas_censo_escolar_da_educacao_basica_2016.pdf>.Acesso em 19 out. 2018.

BRASIL. Ministério da Cultura. Quadro geral de comunidades remanescentes de quilombos (CRQs). Disponível em: <http://www.palmares.gov.br/wp-content/uploads/2016/06/QUADRO-RESUMO.pdf>. Acesso em: 27 fev. 2017.

BRASIL. Lei 10.639/2003, de 9 de janeiro de 2003. Altera a Lei nº 9. 394, de 20 de dezembro de 1996. Disponível em: <http:/ / www.planalto.gov.br/CCIVIL_03/LEIS/2003/L10.639.htm>. Acesso em: 19 out. 2018.

BRASIL. Lei no 9.394/96, de 20 de dezembro de 1996. Disponível em: < http:/ /www.planalto.gov.br/ccivil_03/Leis/L9394.htm>. Acesso em: 27 fev. 2018.

CANDAU, V. M. Multiculturalismo e educação: desafios para a prática pedagógica. In: MOREIRA, A. F; CANDAU, V. M (Org.). Multiculturalismo: diferenças culturais e práticas pedagógicas. 2. ed. Petrópolis, RJ: Vozes, 2008.

CANEN, A; OLIVEIRA, A. M. A. Multiculturalismo e currículo em ação: um estudo de caso. Rev. Bras. Educ., Rio de Janeiro, n. 21, p. 61-74, 2002.

CARVALHO, S. R. Os múltiplos sentidos da categoria “empowerment” no projeto de promoção à saúde. Cad. Saúde Pública, Rio de Janeiro, v. 20, n. 4, p. 1088-1095, 2004.

FREIRE, P.; SHOR, I. Medo e ousadia: o cotidiano do professor. Trad.: Adriana Lopes. 2. ed. Rio de Janeiro: Paz e Terra, 1986. 
GOHN, M. G. Empoderamento e participação da comunidade em políticas sociais. Saúde e Sociedade, São Paulo, v. 13, n. 2, p. 20-31, 2004.

GOMES, V. Organização social e festas como veículos de educação não-formal. IN: BRASIL, Ministério da Educação. Educação Quilombola. Brasília: Salto para o Futuro. Boletim, n. 10, jun. 2007. Disponível em: <https://www.geledes.org.br/wp-content/uploads/2017/03/Educacao-quilombola.pdf>. Acesso em: 19 out. 2018.

HERMANY, R; COSTA, D. L. A necessária superação do modelo representativo hegemônico na construção do empoderamento social local. Revista do Direito, Santa Cruz do Sul, n. 32, p. 78-91, 2009.

HOROCHOVSKI, R. R.; MEIRELLES, G. Problematizando o conceito de empoderamento. Seminário Nacional Movimentos Sociais, Participação e Democracia. Florianópolis, 2., 2007.

KLEBA, M. E. Empoderamento: processo de fortalecimento dos sujeitos nos espaços de participação social e democratização política. Saúde e Sociedade, São Paulo, v. 18, n. 4, p. 733-743, 2009.

LARCHERT, J. M.; OLIVEIRA, M. W. Panorama da educação quilombola no Brasil. Políticas Educativas, Porto Alegre, v. 6, n. 2, p. 44-60, 2013.

LOPES, A. L. Kalunga, escola e identidade: experiências inovadoras de educação nos quilombos. In: BRASIL, Ministério da Educação. Educação quilombola. Brasília: Salto para o Futuro. Boletim n. 10, 2007. Disponível em: <https:/ /www.geledes.org.br/wp-content/uploads/2017/03/Educacao-quilombola.pdf>. Acesso em: 19 out. 2018.

MOURA, G. Quilombo: Conceito. In: BRASIL. Ministério da Educação. Educação quilombola. Brasília: Salto para o Futuro. Boletim n. 10, 2007. Disponível em: <https://www.geledes.org.br/wp-content/uploads/2017/03/Educacao-quilombola.pdf>. Acesso em: 19 out. 2018.

MOREIRA, A. F. B.; TADEU, T. Sociologia e teoria crítica do currículo: uma introdução. . In: MOREIRA, A. F; SILVA, T. T. (Org.). Currículo, cultura e sociedade. 12. ed. São Paulo: Cortez, 2011. 
NASCIMENTO, A. Quilombismo: um conceito emergente do processo histórico cultural da população afro-brasileira. In: NASCIMENTO, E. L (Org.). Afrocentridade: uma abordagem epistemológica inovadora. São Paulo: Selo Negro, 2009.

OLIVEIRA, M. A. J; MARTINS, R. Educação escolar quilombola: currículo e cultura afirmando negras identidades. Poiésis, Tubarão, v. 8, n. 13, p. 189-202, 2014.

SACRISTÁN, J. G. O currículo: uma reflexão sobre a prática. Porto Alegre: Artmed, 2000.

SANTOMÉ, J. T. As culturas negadas e silenciadas no currículo. In: SILVA, T. T. (Org.). Alienígenas na sala de aula. Petrópolis, RJ: Vozes, 1995.

SILVA, T. T. Documentos de identidade: uma introdução às teorias do currículo. 2. ed. Belo Horizonte: Autêntica, 2005.

STOTZ, E. N.; ARAÚJO, J. W. G. Promoção da saúde e cultura política: a reconstrução do consenso. Saúde e Sociedade, São Paulo, v. 13, n. 2, p. 5-19, 2004.

ZIMMERMAN, M. Empowerment Theory: Psychological, Organizational and Community Levels of Analysis. In: RAPPAPORT, J.; SEIDMAN, E. Handbook of Community Psychology. Springer Science \& Business Media, 2000.

recebido em 5 mar. 2018 / aprovado em 24 jul. 2018

Para referenciar este texto:

SANTOS, M. A. R.; SANTOS, C. A. F. Currículo multicultural como instrumento de empoderamento de escolas quilombolas. Cadernos de Pós-graduacão, São Paulo, v. 17, n.2, p. 55-74, jul./dez. 2018. Disponível em: <https://doi.org/10.5585/cpg.v17n2.8436>. 


\title{
A FormaÇÃo Docente Continuada PaRa AS RelaÇões ÉtNiCo-RaCiaIS no Rio de Janeiro: A eXPeriênCia do Programa de Estudo Sobre o Negro NA SOCIEDAdE BRASILEIRA (PENESB/UFF)
}

\section{THE CONTINUED TEACHING TRAINING FOR ETHNIC-RACIAL RELATIONS IN RIO DE JANEIRO: THE EXPERIENCE OF THE PENESB / UFF COURSE}

\begin{abstract}
Vitor Leandro de Souza
Doutorando em História Social da Cultura pela Pontifícia Universidade Católica do Rio de Janeiro. Professor do Colégio Stella Maris. Rio de Janeiro - RJ - Brasil vitorleandro@id.uff.br
\end{abstract}

Tiago Dionísio da Silva Mestre em Educação pela Universidade Federal Rural do Rio de Janeiro. Formador da área de Ciências Humanas da Secretaria Estadual de Educação do Rio de Janeiro. Rio de Janeiro - RJ - Brasil tiago_dionisio@hotmail.com.br

Tatiane Pacheco de Mattos Mestre em Educação pela Universidade Federal Rural do Rio de Janeiro.Professora das Redes Municipal de Mesquita e Estadual do Rio de Janeiro. Rio de Janeiro - RJ - Brasil prof.tatianerj@gmail.com

Resumo: Após 15 anos da aprovação da Lei $n^{\circ}$ 10.639/2003, sobre a obrigatoriedade do ensino da História e Cultura Afro-Brasileira, percebemos inúmeros entraves para sua implantação dentre eles a formação docente. Neste texto refletimos sobre os marcos legais que tangem a formação continuada, desaguando posteriormente na Educação das Relações Étnico-Raciais e, por fim, nas experiências teórico-metodológica do curso de especialização em Educação e Relações Raciais do PENESB/UFF. Tal experiência se mostra original e diferenciada frente aos demais cursos existentes no estado do Rio de Janeiro, pois além de ter como objetivo central a intervenção e transformação da realidade a partir do chão da sala de aula, também leva em consideração os fatores que impedem aos professores da Educação Básica investirem em seus estudos.

Palavras-chave: Formação Continuada. Relações Étnico-Raciais. PENESB/UFF.

Cadernos de Pós-graduação, São Paulo, v. 17, n. 2, p. 75-97, jul./dez. 2018. 
Abstract: After 15 years of the approval of Law number 10.639 / 2003, on the compulsory teaching of Afro-Brazilian Culture and History, we realized that are a large number of obstacles to the total implementation of that program, among them, the teaching training. In this article, we reflect about the legal frameworks for continuing education, which later developed into the Education of Ethnic-Racial Relations and, finally, the theoretical-methodological experiences of the specialization course in Education and Racial Relations of PENESB / UFF. This experience is original and differentiated in comparison to other courses in the Rio de Janeiro state, because besides having as a central objective the intervention and transformation of reality of the classroom, also takes into consideration the factors that prevent the Basic Education teachers to invest in their studies.

Keywords: Continuing Education. Ethnic-Racial Relations. PENESB/UFF

\section{Introdução}

ano de 2018 é um ano particularmente rico de significados para a te-
mática racial no Brasil. Primeiramente pelo aniversário de 130 da Lei Áurea, mas também por completar 15 anos de aprovação de Lei 10.639 de 2003 que alterou a Lei de Diretrizes e Bases da Educação Nacional (LDBEN), Nº 9.394 de 1996 e inseriu, nos mais diferentes níveis educacionais brasileiros, a obrigatoriedade do ensino da História e Cultura Afro-Brasileira.

Todavia, em um cenário de crise institucional, social e política em que políticas de estado e órgãos promovedores de reconhecimento e reparação de dívidas sociais, são fechados, como por exemplo a SEPPIR (Secretaria Especial de Políticas de Promoção da Igualdade Racial) e o CNPIR (Conselho Nacional de Promoção da Igualdade Racial), nos indagamos se existemmotivos para festejarmos?

Então, considerando esse contexto político educacional e a partir da nossa experiência frente às ações formativas desenvolvidas pelo Programa de Estudo do Negro na Sociedade Brasileira (PENESB) da Universidade Federal Fluminense (UFF), fundado e coordenado pela professora Iolanda de Oliveira, em 1995, portanto oito anos antes da implantação da Lei 10639/03, já demonstrava, assim, uma preocupação com 
a Educação da população negra no Brasil. E uma das possíveis ações/soluções em prol de uma Promoção da Igualdade Racial no Brasil pelo viés educacional é o investimento na formação continua para as Relações Étnico-Raciais.

Após completar 15 anos de aprovação da Lei no 10.639/2003, percebemos que sua implantação ainda encontra inúmeros entraves, dentre as dificuldades de assimilação e execução no ambiente escolar destacamos como principais fatores:

- Ausênciade conhecimento teórico do professorado;

- a formação docente inicial insuficiente para abordar em sala de aula tais questões;

- enfrentamento com o fim da desconstrução do mito da democracia racial;

- isso tudo alicerça a concepção docente e os pilares que a educação brasileira foi constituída.

O sistema escolar tem características hierárquicas seletivas e é "racializado". Que vem sendo construído desde o século passado com o objetivo de integrar seletivamente a pobres e negros. Segundo Arroyo (2007, p. 116) "nosso sistema é das décadas de 1930-1950, quando se coloca o problema da integração dos setores populares, às massas urbanas. Décadas em que a ideologia da democracia racial estava no auge”. Como destaca Arroyo (2007), é no contexto ditado pela ideologia da democracia racial que o sistema escolar público promoverá uma "inclusão excludente" ou uma "integração seletiva" concluindo, portanto, que o sistema educacional vigente traz consigo um vício de origem que é muito eficaz para os propósitos excludentes pelo qual foi estruturado, isso perpassa pela formação docente e desagua no chão da sala de aula potencializandoa exclusão, pois desconstruir esta situação é mexer na estrutura racista da sociedade brasileira.

Segundo Munanga (2005, p. 63), 
A FORMAÇ̃̃O DOCENTE CONTINUADA PARA AS RELAÇÕES ÉTNICO-RACIAIS NO RIO DE JANEIRO: A EXPERIÊNCIA DO PROGRAMA DE ESTUDO SOBRE O NEGRO NA SOCIEDADE BRASILEIRA (PENESB/UFF)

[...] a formação de professores que não tiveram em sua base de formação a história da África, a cultura do negro no Brasil e a própria história do negro de um modo geral se constitui no problema crucial das novas leis que implementaram o ensino da disciplina nas escolas. E isso não simplesmente por causa da falta de conhecimento teórico, mas, principalmente, porque o estudo dessa temática implica no enfrentamento e derrubada do mito da democracia racial que paira sobre o imaginário da grande maioria dos professores.

A mudança nos métodos pedagógicos e uma formação docente que ofereçam subsídios para os professores trabalharem com a diversidade de forma igualitária, respeite e valorize as diferenças, são elementos imprescindíveis para estimular uma perspectiva cultural que abarque a complexidade das culturas e das experiências humanas, tanto a nível local quanto a nível global. Para avançarmos, precisamos compreender, de fato, a Lei 10.639/03, a Resolução CNE/CP 01/2004, Parecer CNE/CP 03/2004 e as Diretrizes Curriculares Nacionais para a Educação das Relações Étnico-Raciais e para o Ensino de História e Cultura Afro-Brasileira e Africana 10/2004 dentro do sistema complexo que são as Relações Étnico-Raciais no Brasil. Uma vez que, como observa Gomes (2011, p. 116):

A lei e as diretrizes entram em confronto com as práticas e com o imaginário racial presentes na estrutura e no funcionamento da educação brasileira, tais como o mito da democracia racial, o racismo ambíguo, a ideologia do branqueamento e a naturalização das desigualdades raciais.

Partindo dessas perspectivas e levando em conta quea formação continuada está prevista em documentos oficiais que se tornam marcadores legais no campo educacional, apresentaremos o compilado legislativo que tange a formação continuada do docente, desaguando mais adiante na especificidade da problemática relativa a Educação das Relações Étnico-Raciais e seus marcos legais. E, por fim, dissertaremos sobre as ações formativas desenvolvidas pelo PENESB/UFF através de curso de formação 
continuada me nível de especialização no campo da Educação e Relações Raciais para professores da Educação Básica, tendo como enfoque principal, analisar a concepção teórico-metodológica em que se baseia as referidas ações formativas, que as tornam originais e diferenciadas frente as demais ofertas de curso no estado do Rio de Janeiro.

\section{Formação continuada e os marcos legais: breves reflexões}

Falar de formação continuada nos faz subentender que houve uma formação inicial e que se pretende galgar novos passos. Pensamos que, antes de falarmos do presente é necessário visitar o passado para lembrar-se de onde saímos, e conjecturar para aonde estamos caminhando.

Em 20 de dezembro de 1996 foi promulgada a Lei no 9.394/96, com as Diretrizes e Bases da Educação Nacional (LDBEN), sendo esta, atualmente,um dos marcos legais de maior influência nas políticas públicas de formação continuada. O texto da LDBEN discorre por 9 capítulos sendo o capítulo VI (artigos 61 ao 67) destinado aos Profissionais da Educação, instituindo no artigo 62 critérios para o exercício docente na Educação Básica, estabelecendo no seu parágrafo $1^{\circ}$ que "A União, o Distrito Federal, os Estados e os Municípios, em regime de colaboração, deverão promover a formação inicial, a continuada e a capacitação dos profissionais de magistério". Acrescenta ainda no parágrafo $2^{\circ}$ que "A formação continuada e a capacitação dos profissionais de magistério poderão utilizar recursos e tecnologias de educação a distância.” (BRASIL, 1996).

Percebemos que no primeiro parágrafo $1^{\circ}$ o verbo “deverão" tem caráter obrigatório, ou seja, a formação continuada não é facultativa as esferas governamentais e sim tem um caráter de obrigatoriedade que deve ser assumido pelos gestores públicos 
A FORMAÇ̃̃O DOCENTE CONTINUADA PARA AS RELAÇÕES ÉTNICO-RACIAIS NO RIO DE JANEIRO: A EXPERIÊNCIA DO PROGRAMA DE ESTUDO SOBRE O NEGRO NA SOCIEDADE BRASILEIRA (PENESB/UFF)

como prioridade. Já no parágrafo $2^{\circ}$ o verbo “poderão”tem caráter permissivo, no sentido de que os recursos disponibilizados pelo Ministério da Educação e Cultura (MEC) não precisam ser direcionados para cursos de formação. Ou seja, o texto da lei não estabelece para os gestores quais valores devem ser aplicados na formação continuada dos docentes.

O Artigo 62A, em seu Parágrafo Único:

Garantir-se-á formação continuada para os profissionais a que se refere ocaput, no local de trabalho ou em instituições de educação básica e superior, incluindo cursos de educação profissional, cursos superiores de graduação plena ou tecnológicos e de pós-graduação (BRASIL, 1996).

O texto abre prerrogativa para possíveis formações em escalas macro e micro dentro dos sistemas de ensino. O que coaduna com o artigo 63, estabelecendo aos institutos superiores de educação como mantenedores de programas de educação continuada para os profissionais de educação nos diversos níveis, consoante ao inciso III.

Encerrando o capítulo VI com o artigo 67, a lei delibera que os sistemas de ensino promovam a valorização dos profissionais da educação através, também, do aperfeiçoamento profissional continuado, inclusive com licenciamento periódico remunerado para esse fim, conforme inciso II.

O MEC, buscando fortalecer a ações articuladas com os sistemas de ensino de combate a desigualdade social, institui em 2004 a Secretaria de Educação Continuada, Alfabetização e Diversidade (SECAD), atualmente, Secretaria de Educação Continuada, Alfabetização, Diversidade e Inclusão (SECADI), sendo esta a responsável por contribuir com a efetivação de políticas públicas para o "desenvolvimento inclusivo 
dos sistemas de ensino, voltado à valorização das diferenças e da diversidade, à promoção da educação inclusiva, dos direitos humanos e da sustentabilidade socioambiental".

Em 2004 o MEC amplia a ações da SECADI, através da Rede Nacional de Formação Continuada de Professores, buscando fomentar - em áreas de concentração como alfabetização e linguagem, educação matemática e científica, ensino de ciências humanas e sociais, artes e educação física - a melhoria na formação de professores da Educação Básica da rede pública de ensino, contribuindo assim para o processo de ensino e aprendizagem do corpo discente.

Imbernón (2010) faz críticas à estrutura existente em prol da formação continuada docente, afirmando que são necessárias mudanças tanto nas políticas públicas quanto na prática docente, pois os últimos anos tais ações assumiram caráter pontuais e descontinuadas. Embora este seja um processo dinâmico de constante reflexão, percebemos que a práxis docente dominante no cotidiano ainda se resume a ações uniformes e simplistas.

Outro marco representativo para a formação continuada do Professor é apontado pelo Plano Nacional de Educação (PNE) - Decênio 2014a 2024, que apresenta um conjunto de 10 diretrizes orientadoras para implantação de estratégias para execução de 20 metas, distribuídas em 4 blocos para avançar ao longo do decênio.

O primeiro bloco trata da garantia de acesso à matrícula; O segundo propõe a redução das desigualdades e à valorização da diversidade; O terceiro apresenta as metas que tratam da valorização dos profissionais da educação; o quarto, e último, se refere ao Ensino Superior.Nos deteremos no bloco três, especialmente meta 16, que explicita como objetivo: 
A FORMAÇ̃̃O DOCENTE CONTINUADA PARA AS RELAÇÕES ÉTNICO-RACIAIS NO RIO DE JANEIRO: A EXPERIÊNCIA DO PROGRAMA DE ESTUDO SOBRE O NEGRO NA SOCIEDADE BRASILEIRA (PENESB/UFF)

Formar, em nível de pós-graduação, cinquenta por cento dos professores da educação básica, até o último ano de vigência deste PNE, e garantir a todos (as) os (as) profissionais da educação básica formação continuada em sua área de atuação, considerando as necessidades, demandas e contextualizações dos sistemas de ensino.(BRASIL, 2014, p. 35).

Embora apenas a meta 16 seja específica enquanto a formação continuada há outras que são estratégicas e compreendem tal formaçãocomopilar para o alcance de outras demandas.

Tabela 1 - Outras metas e a questão formação docente continuada. Estratégias e ações adotadas para a implementação e a execução do PNE.

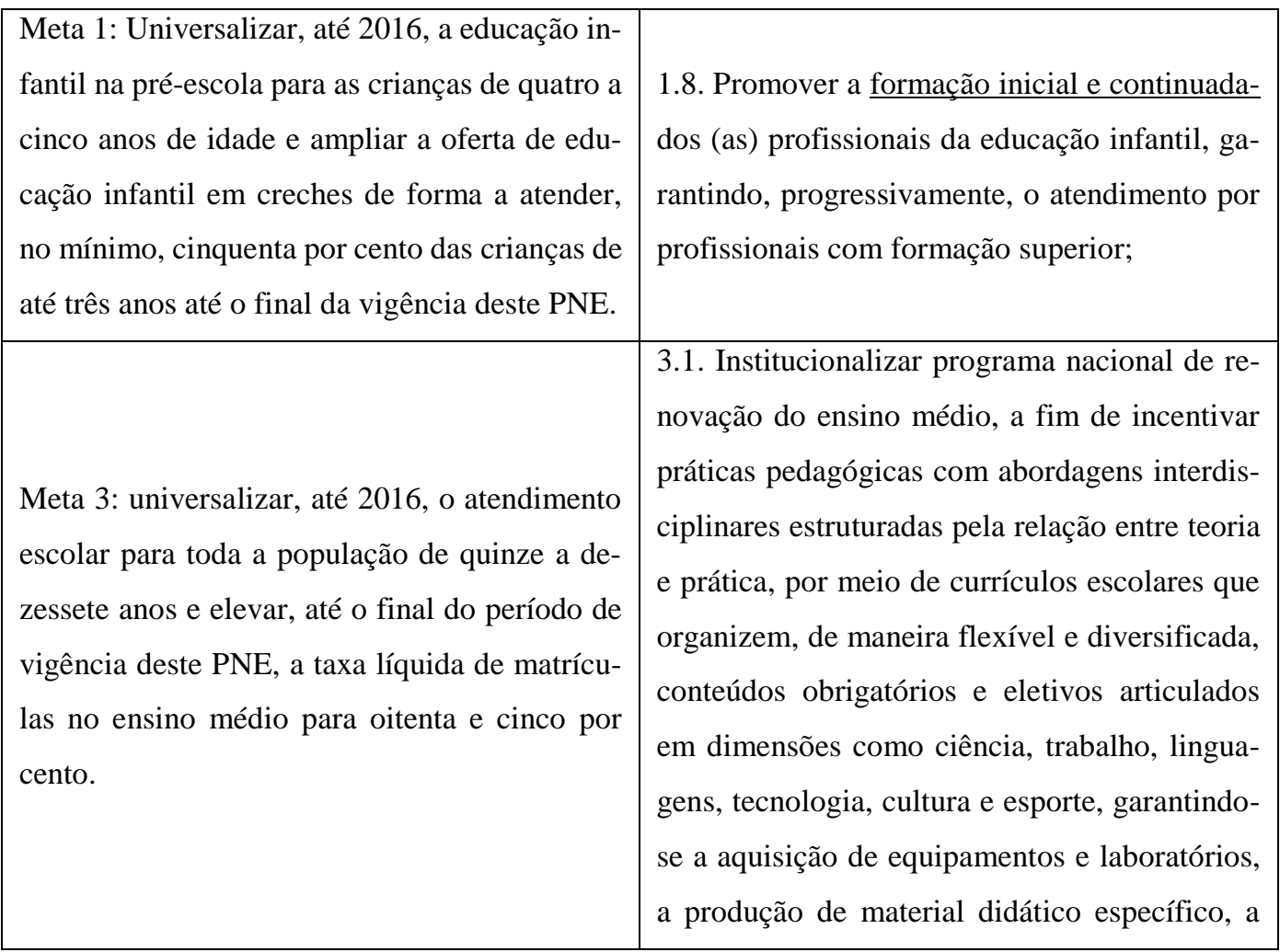

Cadernos de Pós-graduação, São Paulo, v. 17, n. 2, p. 75-97, jul./dez. 2018. 


\begin{tabular}{|c|c|}
\hline & $\begin{array}{l}\text { formação continuada de professorese a articula- } \\
\text { ção com instituições acadêmicas, esportivas e } \\
\text { culturais. }\end{array}$ \\
\hline $\begin{array}{l}\text { Meta 4: universalizar, para a população de qua- } \\
\text { tro a dezessete anos com deficiência, transtor- } \\
\text { nos globais do desenvolvimento e altas habili- } \\
\text { dades ou superdotação, o acesso à educação bá- } \\
\text { sica e ao atendimento educacional especiali- } \\
\text { zado, preferencialmente na rede regular de en- } \\
\text { sino, com a garantia de sistema educacional in- } \\
\text { clusivo, de salas de recursos multifuncionais, } \\
\text { classes, escolas ou serviços especializados, pú- } \\
\text { blicos ou conveniados. }\end{array}$ & $\begin{array}{l}\text { 4.3. Implantar, ao longo deste PNE, salas de re- } \\
\text { cursos multifuncionais e fomentar a formação } \\
\text { continuada de professores e professoras para o } \\
\text { atendimento educacional especializado nas es- } \\
\text { colas urbanas, do campo, indígenas e de comu- } \\
\text { nidades quilombolas. } \\
\text { 4.18. Promover parcerias com instituições co- } \\
\text { munitárias, confessionais ou filantrópicas sem } \\
\text { fins lucrativos, conveniadas com o poder pú- } \\
\text { blico, visando a ampliar a oferta de formação } \\
\text { continuada e a produção de material didático } \\
\text { acessível, assim como os serviços de acessibili- } \\
\text { dade necessários ao pleno acesso, participação } \\
\text { e aprendizagem dos estudantes com deficiên- } \\
\text { cia, transtornos globais do desenvolvimento e } \\
\text { altas habilidades ou superdotação matriculados } \\
\text { na rede pública de ensino. }\end{array}$ \\
\hline $\begin{array}{l}\text { Meta 5: alfabetizar todas as crianças, no má- } \\
\text { ximo, até o final do terceiro ano do ensino fun- } \\
\text { damental. }\end{array}$ & $\begin{array}{l}\text { 5.6. Promover e estimular a formação inicial e } \\
\text { continuada de professores (as) para a alfabeti- } \\
\text { zação de crianças, com o conhecimento de no- } \\
\text { vas tecnologias educacionais e práticas pedagó- } \\
\text { gicas inovadoras, estimulando a articulação en- } \\
\text { tre programas de pós-graduação stricto sensu e } \\
\text { ações de formação continuada de professores } \\
\text { (as) para a alfabetização. }\end{array}$ \\
\hline $\begin{array}{l}\text { Meta 7: fomentar a qualidade da educação bá- } \\
\text { sica em todas as etapas e modalidades, com me- } \\
\text { lhoria do fluxo escolar e da aprendizagem de }\end{array}$ & $\begin{array}{l}\text { 7.4. Induzir processo contínuo de autoavaliação } \\
\text { das escolas de educação básica, por meio da } \\
\text { constituição de instrumentos de avaliação que }\end{array}$ \\
\hline
\end{tabular}

Cadernos de Pós-graduação, São Paulo, v. 17, n. 2, p. 75-97, jul./dez. 2018. 
A FORMAÇ̃̃O DOCENTE CONTINUADA PARA AS RELAÇÕES ÉTNICO-RACIAIS NO RIO DE JANEIRO: A EXPERIÊNCIA DO PROGRAMA DE ESTUDO SOBRE O NEGRO NA SOCIEDADE BRASILEIRA (PENESB/UFF)

\begin{tabular}{|c|c|}
\hline $\begin{array}{l}\text { modo a atingir as seguintes médias nacionais } \\
\text { para o IDEB [...] }\end{array}$ & $\begin{array}{l}\text { orientem as dimensões a serem fortalecidas, } \\
\text { destacando-se a elaboração de planejamento es- } \\
\text { tratégico, a melhoria contínua da qualidade } \\
\text { educacional, a formação continuada dos (as) } \\
\text { profissionais da educaçãoe o aprimoramento da } \\
\text { gestão democrática; } \\
\text { 7.22. Informatizar integralmente a gestão das } \\
\text { escolas públicas e das secretarias de educação } \\
\text { dos estados, do Distrito Federal e dos municí- } \\
\text { pios, bem como manter programa nacional de } \\
\text { formação inicial e continuada para o pessoal } \\
\text { técnico das secretarias de educação; } \\
\text { 7.26. consolidar a educação escolar no campo } \\
\text { de populações tradicionais, de populações itine- } \\
\text { rantes e de comunidades indígenas e quilombo- } \\
\text { las, respeitando a articulação entre os ambientes } \\
\text { escolares e comunitários e garantindo: o desen- } \\
\text { volvimento sustentável e preservação da identi- } \\
\text { dade cultural; a participação da comunidade na } \\
\text { definição do modelo de organização pedagó- } \\
\text { gica e de gestão das instituições, consideradas } \\
\text { as práticas socioculturais e as formas particula- } \\
\text { res de organização do tempo; a oferta bilíngue } \\
\text { na educação infantil e nos anos iniciais do en- } \\
\text { sino fundamental, em língua materna das comu- } \\
\text { nidades indígenas e em língua portuguesa; a re- } \\
\text { estruturação e a aquisição de equipamentos; a } \\
\text { oferta de programa para a formação inicial e } \\
\text { continuada de profissionais da educação; e o }\end{array}$ \\
\hline
\end{tabular}

Cadernos de Pós-graduação, São Paulo, v. 17, n. 2, p. 75-97, jul./dez. 2018. 


\begin{tabular}{|c|c|}
\hline $\begin{array}{l}\text { Meta 10: oferecer, no mínimo, vinte e cinco por } \\
\text { cento das matrículas de educação de jovens e } \\
\text { adultos, nos ensinos fundamental e médio, na } \\
\text { forma integrada à educação profissional. }\end{array}$ & $\begin{array}{l}\text { 10.7. Fomentar a produção de material didático, } \\
\text { o desenvolvimento de currículos e metodolo- } \\
\text { gias específicas, os instrumentos de avaliação, } \\
\text { o acesso a equipamentos e laboratórios e a for- } \\
\text { mação continuada de docentes das redes públi- } \\
\text { cas que atuam na educação de jovens e adultos } \\
\text { articulada à educação profissional. }\end{array}$ \\
\hline $\begin{array}{l}\text { Meta 15: garantir, em regime de colaboração } \\
\text { entre a União, os estados, o Distrito Federal e } \\
\text { os municípios, no prazo de um ano de vigência } \\
\text { deste PNE, política nacional de formação dos } \\
\text { profissionais da educação de que tratam os in- } \\
\text { cisos I, II e III do caput do art. } 61 \text { da Lei no } \\
\text { 9.394, de } 20 \text { de dezembro de } 1996 \text {, assegurado } \\
\text { que todos os professores e as professoras da } \\
\text { educação básica possuam formação específica } \\
\text { de nível superior, obtida em curso de licencia- } \\
\text { tura na área de conhecimento em que atuam. }\end{array}$ & $\begin{array}{l}\text { 15.4. Consolidar e ampliar plataforma eletrô- } \\
\text { nica para organizar a oferta e as matrículas em } \\
\text { cursos de formação inicial e continuada de pro- } \\
\text { fissionais da educação, bem como para divulgar } \\
\text { e atualizar seus currículos eletrônicos; }\end{array}$ \\
\hline
\end{tabular}

Fonte: Elaborada a partir das Metas e Estratégias do PNE 2014 a 2024 (BRASIL, 2014). (Grifo nosso).

Dada a relevância da formação continuada, é reconhecido através do Plano Nacional de Educação que para atingir objetivos propostos é necessário investir no grupo de profissionais de educação.

Portanto, estabelecer política de valorização dos profissionais da educação em cada rede ou sistema de ensino é fundamental para que a política educacional se fortaleça. Quanto mais sustentáveis forem as carreiras e quanto mais integradas forem as decisões relativas à formação mais ampliadas serão as perspectivas da equidade da oferta educacional. (BRASIL, 2014, p.13). 
A FORMAÇÃO DOCENTE CONTINUADA PARA AS RELAÇÕES ÉTNICO-RACIAIS NO RIO DE JANEIRO: A EXPERIÊNCIA DO PROGRAMA DE ESTUDO SOBRE O NEGRO NA SOCIEDADE BRASILEIRA (PENESB/UFF)

A formação continuada docente para as relações étnico-raciais: discussões iniciais

A análise dos dados do Censo escolar referente ao ano de 2014 demonstrou uma que mesmo mais da metade da população brasileira (50,7\%) declarou-se negra, tal população não está representada na mesma proporção nos níveis elevados educacionais. Ou seja, quanto maior o tempo de escolarização, menor é o percentual de negros nas salas de aula. Enquanto na educação infantil o acesso da população branca é de 42,9\%, os negros são 39,8\%. Os números melhoram consideravelmente durante o ensino fundamental, praticamente não existindo diferenças entre negros e brancos (ambas atingem 92\%). Todavia, durante o ensino médio a queda da frequência líquida de negros e brancos volta a apresentar a profunda desigualdade racial do nosso país, enquanto a permanência de negros é de pouco mais de 49\%, os brancos são de 63,7\% (BRASIL, 2015).

Os dados apresentados traduzem em números a realidade brasileira baseada na desigualdade racial, especialmente na educação e corroboram para a necessidade do enfrentamento comprometido por parte de gestores públicos nos mais diferentes níveis tendo em vista oferecer respostas para a problemática.Nesse sentido o Parecer 03/2004 ressalta a importância das políticas de reparação, explicando que reconhecer tal demanda "exige que os estabelecimentos de ensino, frequentados em sua maioria por população negra"(BRASIL, 2013, p. 499), tenham professores compromissados na educação para as relações étnico-raciais.

Imbernón (2010) ressalta que a análise do contexto político-social é elemento imprescindível na formação, ou seja, as demandas postas precisam ser refletidas e poli- 
tizadas pelos sujeitos envolvidos. Nesta mesma perspectiva, em 2004, através de reivindicações e propostas do Movimento Negro, apontadas ao longo do século XX, foi registrada a necessidade de políticas públicas que promovessem a valorização da história e cultura dos afro-brasileiros e africanos nas escolas através de diretrizes, conforme apontado pelo Parecer 003/2004. (BRASIL, 2013).

Buscando a ruptura com o fundamentalismo pedagógico² ${ }^{2}$ arcado pelo etnocentrismo europeu, alicerçado na reprodução do que está posto, este tem caráter inibidor ao ato de questionar, sendo este último compreendido como ameaças ao convívio social (LIMA, 2009) entendemos que a formação continuada de professores para a educação das relações étnico-raciais é uma ferramenta para romper com o status quo.

Segundo Silvio Gallo (2009) essas características que emanam do fundamentalismo pedagógico são facilmente identificados em políticas públicas educacionais, nos Projetos Político-Pedagógicos (PPP) das unidades escolares e nas práticas docente.

$\mathrm{Na}$ tentativa de descontinuar com ações aplicadas nas instituições escolares desde outrora, o Parecer $03 / 2004^{3}$ menciona que para o tipo de política que se pretende implementar sãonecessáriosprofessores“com formação [adequada] para lidar com as tensas relações produzidas pelo racismo e discriminações” (BRASIL, 2013, p. 498).

A formação continuada mostra-se como ação imprescindível para tema proposto através da alteração da LDBEN n 9.394/96 nos artigos 26A e 79B instituído pela Lei 10.639/03, evitando a improvisação, conforme o Parecer 03/2004 aponta:

Para obter êxito, a escola e seus professores não podem improvisar. Têm que desfazer mentalidade racista e discriminadora secular, superando o etnocentrismo europeu, reestruturando relações étnicoraciais e sociais, desalienando processos pedagógicos. (BRASIL, 2013, p. 501).

Cadernos de Pós-graduação, São Paulo, v. 17, n. 2, p. 75-97, jul./dez. 2018. 
A FORMAÇ̃̃O DOCENTE CONTINUADA PARA AS RELAÇÕES ÉTNICO-RACIAIS NO RIO DE JANEIRO: A EXPERIÊNCIA DO PROGRAMA DE ESTUDO SOBRE O NEGRO NA SOCIEDADE BRASILEIRA (PENESB/UFF)

Para discutir sobre o improviso na Educação para as Relações Étnico-raciais é importante trazer as perspectivas de Oliveira (2006). Ao se debruçado sobre as questões do cenário político, do planejamento escolar, e das práticas pedagógicas, a autora cita que o período político é fator preponderante para corrente pedagógica aplicada na escola, pois este definirá os princípios e fins da educação no país.Para ela um dos possíveis caminhos é o uso da pedagogia progressista, por tratar-se deuma "concepçãopedagógica que contém os elementos necessários a uma atuaçãocomprometida com a transformação da sociedade e, portanto, com a eliminação de qualquer tipo de discriminação"(OLIVEIRA, 2006, p.50), e que, portanto, auxilia na orientação da formação de profissionais da educação em prol da diversidade racial brasileira.

Estamos em consonância com Oliveira por entendermos que essa transformação socialinicia-se no planejamento escolar, evitando improvisos. Ou seja, "A ênfase no planejamento é dada no sentido de que se tenha a possibilidade de promover as mudanças que se fazem necessáriaspara garantir a igualdade racial em educação". (OLIVEIRA, 2006, p. 46). Cabendo aos professores autonomia e preparo para atuarem politicamente sobre os conteúdos escolares em prol de uma educação antirracista. Neste sentido, o planejamento antecede a ação docente, onde vai predizer os objetivos, as habilidades e as competências, que deverão considerar a população negra na perspectiva de valorização e reconhecimento da história, identidade e cultura dos afro-brasileiros e dos africanos, conforme apontamas Diretrizes Curriculares Nacionais da Educação das Relações Étnico-Raciais (BRASIL, 2004).

Bento (2002) aponta que tais iniciativas são apresentadas como esforços para combater o soterramento da história e cultura afro-brasileira e africana, confrontando práticas docentes que silenciam, mutilam e distorcem a temática racial, investindo no 
imaginário coletivo sobre os negros de forma depreciativa, pejorativas e os desumanizados. Assim, a desvalorização sobre o negro apresentada nos documentos norteadores produzidos pelas escolas na perspectiva do fundamentalismo pedagógico, provoca no aluno o não sentimento de pertença a esse grupo étnico-racial, “descontente e desconfortável com sua condição de negro, procura identificar-se como branco.” (Idem, p. 1).

Bento questiona o ditame da branquitude, que para ela, trata-se de processo histórico em que o branqueamento da população foi realizado através da imigração europeia, e a implantação de ações simbólicas e concretas para o reforço do racismo. Deste modo, "Eles reconhecem as desigualdades raciais, só que não associam essas desigualdades raciais à discriminação e isto é um dos primeiros sintomas da branquitude" (BENTO, 2002, p.2). É uma desigualdade reconhecida, porém não associada à estratégia alternativa para manter o estado de equilíbrio da elite dominante.

Compreendemos que tal situação passa pelo chão da sala de aula, desta maneira uma das ações de transformação começa pela formação dos educadores para a igualdade racial. No processo de formação que respeite a legislação, e que de forma dinâmica auxilie nas ações concretas do engajamento político e social. Onde tais leis, decretos e pareceres, fruto das intensas lutas dos movimentos negros, passam a adquirir concretude da vida vivida e, sirvam de fato para a transformaçãopolítico-social, visando relações étnico-raciais igualitárias.

\section{A experiência dos cursos de especialização do PENESB/UFF}

Em 1995, foi aprovada pela Reitoria da Universidade Federal Fluminense (UFF) a implementação do Programa de Educação sobre o Negro na Sociedade Brasileira (PENESB), na Faculdade de Educação. ${ }^{4}$ Uma iniciativa pioneira, que antecedeu em sete anos a criação da própria lei 10.639/2003, sinal do olhar atento de professores 
A FORMAÇÃO DOCENTE CONTINUADA PARA AS RELAÇÕES ÉTNICO-RACIAIS NO RIO DE JANEIRO: A EXPERIÊNCIA DO PROGRAMA DE ESTUDO SOBRE O NEGRO NA SOCIEDADE BRASILEIRA (PENESB/UFF)

e pesquisadores comprometidos com ações pedagógicas de transformação da realidade em prol de uma educação antirracista. Objetivando

realizar pesquisas sobre a dimensão racial do fenômeno educativo de modo paralelo à disseminação dos conhecimentos sobre o tema, junto à população em geral e em especial junto aos profissionais da educação, interferindo na sua formação inicial e continuada. (PENESB, 1996-1997apud SANTOS, 2007, p. 67).

Tal aspiração, de levar as reflexões extramuros da universidade, se concretiza em iniciativas como, por exemplo, a organização e promoção de eventos em que os participantes estavam vinculados à UFF, mas também à população em geral. Deste modo, a equipe PENESB possibilitava

aos profissionais da Educação e à população em geral a oportunidade de ter acesso à produção de saberes e às práticas pedagógicas que visam explicar e interferir na dimensão racial do fenômeno educativo, com o propósito de reduzir os altos índices de seletividade escolar determinados pelo fator racial. (SANTOS, 2007, p. 68).

O compromisso firmado pelo PENESB, na promoção de uma educação igualitária racialmente, se concretizou - entre os anos de 1995 e 2007 - na oferta de cinco turmas de curso, com média de 35 alunos cada (cerca de 175 concluintes), em nível de especialização, que abordavam a temática das relações étnico-raciais.

A partir de 2009 há uma grande reformulação na atuação do curso PENESB, os cursos passam a ser ministrado à distância. "A experiência exitosa do PENESB com o primeiro grupo de formação continuada a distância, em nível de extensão, motivou o Programa a ousar a oferta do mesmo curso em nível de especialização na mesma modalidade" (OLIVEIRA, 2016, p.8). 
Entretanto, uma preocupação da equipe PENESB consistia em manter a qualidade e excelência que fez do curso um espaço reconhecido, e da sua produção uma referência. A solução encontrada foi o uso de uma modalidade "semipresencial". Em que os alunos poderiam ter acesso aos textos e a inúmeros recursos audiovisuais (como vídeos, músicas e etc.) referente a cada disciplina, e enviar, por meio da plataforma moodle, as tarefas de acordo com o cronograma planejado pela coordenação. O diferencial estava na "aula presencial" que dava início a cada componente curricular.

A proposta do PENESB orientou-se pelo princípio de que a questão principal dos cursos, tanto os de formação inicial, quanto continuada, está vinculada à garantia de qualidade, independente da qualidade da modalidade de ensino em que são oferecidos. Entende-se que em ambas as modalidades, presencial e a distância, respeitandose as particularidades de cada uma, há de se considerar a necessidade de estabelecer critérios de qualidade e uma organização e dinâmica que impeçam o aligeiramento e superficialidade da formação oferecida, isto é, que garantam um nível de ensino compatível com uma atuação docente devidamente qualificada (OLIVEIRA, 2016, p.8).

Disciplinas como "História da África", "O Negro na História do Brasil” e "Teoria Social e Relações Raciais” contaramcom grandes especialistas reconhecidos no campo. Dentre eles, respectivamente, podemos citar os professores Mônica Lima (UFRJ), Marta Abreu (UFF) e Kabengele Munanga (USP). O que demonstra o compromisso com qualidade teórica e o esforço, por parte da equipe PENESB na manutenção de vínculos com pesquisadores comprometidos em "uma formação dos profissionais da educação que dê conta da eliminação deste problema que atinge toda a humanidade" (OLIVEIRA, 2006, p. 128).

Além disso, tal atenção à qualidade se demonstrou através da seleção do corpo de tutores com pesquisas na pós-graduação stricto senso, voltadas para a temática das 
A FORMAÇÃO DOCENTE CONTINUADA PARA AS RELAÇÕES ÉTNICO-RACIAIS NO RIO DE JANEIRO: A EXPERIÊNCIA DO PROGRAMA DE ESTUDO SOBRE O NEGRO NA SOCIEDADE BRASILEIRA (PENESB/UFF)

relações raciais. Desta maneira, ocorre um acompanhamento apurado teórico e metodologicamente, sem perder de vistas a aplicabilidade prática em sala de aula e nos demais espaços de atuação dentro da sociedade.

Ressaltamos que, garantida a qualidade do curso, a modalidade a distância possui vantagens com relação a modalidade presencial, uma vez que, levando em conta o território complexo dos grandes centros urbanos como a Região Metropolitana do Rio de Janeiro, que implica em um considerável gasto financeiro e temporal no que tange no deslocamento, tal situação é amenizada, além de que a evasão também é muito menor, pois os professores da Educação Básica possuem pouco tempo para desenvolver outras atividades apara além o exercício da docência, uma vez que possuem jornadas duplas ou triplas para garantir salários razoáveis para a manutenção mínima da vida.

[...] os cursos de formação continuada a distância nos grandes centros urbanostêm vantagens sobre os cursos presenciais em relação a dois aspectos: redução significativa dos percentuais de desistência e maior assimilação dos conhecimentos curriculares por motivo da realização de tarefas semanais que exigem a leitura de textos básicos apresentados. Sugere-se que esta modalidade deva restringir-se aos grandes centros urbanos, como o Rio de Janeiro, cujos deslocamento, além do alto custo, exigem longo tempo para fazê-lo. Nos cursos presenciais, em geral, noturnos, os profissionais do magistério, tendo uma jornada de trabalho, não raro, dupla e em alguns casos tripla, em sua grande maioria, enfrentam intenso trânsito no deslocamento para universidade, além do aumento do custo deste deslocamento e dos gastos com alimentação fora do espaço residencial, o que provavelmente leva desistência de elevados percentuais dos que se propõem a frequentar os cursos. Além desses fatores, a falta de apoio institucional para continuidade da formação também tem, possivelmente, implicações nos percentuais de desistência, fator este que independe da modalidade. (OLIVEIRA, 2016, p.8).

Vale informar que apesar do êxito e das inúmeras vantagens da modalidade a distância, o PENESB não recomenda a sua expansão sem critérios rigorosos com o fim 
de garantir a qualidade da formação ofertada. A luta sempre deve ser pela oferta da formação inicial e continuada presenciais, "porque entendemos que a educação institucionalizada, embora priorize o conhecimento acadêmico, se dá no âmbito das relações humanas, nas quais o fator emocional, a afetividade, não pode estar ausente" (OLVEIRA, 2016, p. 8).

Nossa preocupação no campo afetivo se dá, por conta que as discussões sobre as Relações Étnico-Raciais sempre impactam no afloramento de sentimentos não trabalhados, escondidos e, muitas vezes revelados de forma violenta e traumatizantes. Como destacou Ana Maria Gonçalves (MELO, s/d) o "racismo é algo que afeta tanto quem o manifesta quanto quem é alvo dele, independente da relação entre estas pessoas, interferindo na quantidade e na qualidade dos sentimentos e das emoções." E Oliveira (2016) ratifica tal posição ao afirmar que:

Tratando-se da educação para as relações raciais, cujos conhecimentos afetam fortemente as emoções de negros e brancos, não se restringindo ao âmbito intelectual, na educação a distância, a afetividade não desaparece totalmente, mas é reduzida pela mediação tecnológica. O contato mediado pela tecnologia impede que o professor online estimule o cursista através de outras linguagens além da escrita, principalmente por meio das expressões e relações corporais diretas (OLIVEIRA, 2016, p. 9).

Assim, o curso em nível de especialização em Educação e Relações ÉtnicoRaciais do oferecido pelo PENESB, tem como os seguintes objetivos:

1. Oferecer aos profissionais em exercício na Escola Básica, oportunidade de:

$\checkmark$ Adquirir conhecimentos que lhes possibilitem compreender e interferir na situação da população negra no sistema nacional da educação, por meio da revisão da sua prática pedagógica, com vistas a uma pedagogia que promova a real democratização das oportunidades educacionais; 
A FORMAÇ̃̃O DOCENTE CONTINUADA PARA AS RELAÇÕES ÉTNICO-RACIAIS NO RIO DE JANEIRO: A EXPERIÊNCIA DO PROGRAMA DE ESTUDO SOBRE O NEGRO NA SOCIEDADE BRASILEIRA (PENESB/UFF)

$\checkmark$ Desenvolver a habilidade de incluir os referidos conhecimentos no seu planejamento pedagógico e, consequentemente, garantir o domínio desses conhecimentos pelos alunos, a fim de tornar as relações raciais entre os estudantes respeitosas e dialógicas, com vistas à incorporação de tais comportamentos nas relações raciais em todos os espaços sociais.

2. Despertar nos cursistas a confiança no potencial dos estudantes pretos e pardos, com o propósito de tornar as relações professoraluno negro capazes de promover a equidade racial;

3. Contribuir para alterar o quadro de desigualdades raciais na educação brasileira (OLIVEIRA, 2016, p.9)

Os referenciais teórico-metodológicos utilizados pelo PENESB foram descritos por Oliveira (2006) como tendo como objetivo primaz inserir a educação a serviço da sociedade brasileira, tendo como ponto central as questões relacionadas à população negra. São eles:

4. Formação fundamentada em uma concepção pedagógica comprometida com a promoção do negro;

5. Estabelecimento da relação de unidade entre teoria e prática;

6. A questão dos valores em educação;

7. A pesquisa ação como metodologia de investigação da própria prática e ou da prática do outro;

8. A legislação brasileira pertinente à educação da população negra e afins (OLIVEIRA, 2006, p.129).

Notamos que tais referenciais visam dinamizar o trabalho docente, inserindo intencionalmente, ou seja é uma atuação política por parte do professorado, os conteúdos, de forma ativa, de modo a promover valores históricos e culturais afro-brasileiros e africanos. Deste modo a educação transforma-se em um instrumento de mudança da realidade concreta, considerando acima de tudo a cultura escolar que estava submetida à cultura do branqueamento. Cabe ao professor, portanto, recontextualizar conteúdos escolares tidos como "tradicionais" de modo a evidenciar traços fundamentais das inúmeras contribuições das populações negras no Brasil. 
Sendo assim, para Oliveira (2006) não há ação docente desvinculada da pesquisa, ao professor cabe um constante exercício de "planejamento e replanejamento" da sua prática pedagógica, buscando alinhá-la aos princípios da educação antirracista. Tal esforço ajudará aos alunos reconhecer criticamente sua condição na sociedade, intervindo e reordenando seu projeto de vida.

\section{Referência}

ARROYO, M. G.. A pedagogia multirracial popular e o sistema escolar. In: GOMES, Nilma Lino (Org.). Um olhar além das fronteiras: educação e relações raciais. Belo Horizonte: Autêntica, 2007. p. 111-130.

BRASIL. Presidência da República. Lei n 10.639, de 9.01.2003. Estabelece as diretrizes e bases da educação nacional, para incluir no currículo oficial da Rede de Ensino a obrigatoriedade da temática "História e Cultura Afro-Brasileira", e dá outras providências. Disponível em <http://www.planalto.gov.br/ccivil_03/leis/2003/L10.639.htm>. Acesso em: 18 out. 2018.

Diretrizes Curriculares Nacionais para a Educação para as Relações ÉtnicoRaciais e para o Ensino de História e Cultura Afro-Brasileira e Africana. In: Diretrizes Curriculares Nacionais Gerais da Educação Básica. Ministério da Educação.Secretaria de Educação Básica. Diretoria de Currículos e Educação Integral. Brasília: MEC, SEB, DICEI, 2004. Disponível em: <http://www.acaoeducativa.org.br/fdh/wp-content/uploads/2012/10/DCN-s-Educacao-das-Relacoes-Etnico-Raciais.pdf $>$. Acesso em: 18 out. 2018.

Lei no. 9.394, de 20.12.1996. Estabelece as Diretrizes e Bases da Educação Nacional. Disponível em < http://www2.camara.leg.br/legin/fed/lei/1996/lei-9394-20-dezembro-1996-362578-publicacaooriginal-1-pl.html>. Acesso em: 18 out. 2018.

Plano Nacional de Educação 2014-2024 [recurso eletrônico]: Lei n 13.005, de 25 de junho de 2014, que aprova o Plano Nacional de Educação (PNE) e dá outras providências. Brasília: Câmara dos Deputados, Edições Câmara, 2014. Disponível em <http://www.observatoriodopne.org.br/uploads/reference/file/439/documento-referencia.pdf $>$. Acesso em: 21 jul. 17. 
A FORMAÇ̃̃O DOCENTE CONTINUADA PARA AS RELAÇÕES ÉTNICO-RACIAIS NO RIO DE JANEIRO: A EXPERIÊNCIA DO PROGRAMA DE ESTUDO SOBRE O NEGRO NA SOCIEDADE BRASILEIRA (PENESB/UFF)

. Ministério da Educação. Educacenso: O item cor/ raça no censo escolar da educação básica. 2015. Disponível em <http://download.inep.gov.br/educacao_basica/educacenso/documentos/2015/cor_raca.pdf>. Acesso em 20 out. 2017.

BENTO, Maria Aparecida da Silva. Branqueamento e branquitude no Brasil. In:__ Iray Carone. (Org.) Psicologia social do racismo - estudos sobre branquitude e branqueamento no Brasil. Petrópolis, RJ: Vozes, 2002. p. 25-58.

GALLO, Silvio. A Vila: microfacismo, fundamentalismo e educação. In:

NETO, José da Veiga Neto. (Org.) Fundamentalismo e Educação. Belo Horizonte: Autêntica. 2009. p. 17-35.

GOMES, Nilma Lino. Educação de Jovens e Adultos e questão racial: algumas reflexões iniciais. In: ; SOARES, Leôncio; GIOVANETTI, Maria Amélia. (Org.). Diálogos na Educação de Jovens e Adultos. Belo Horizonte: Autêntica, 2011. p. 109-121.

MELO, Joyce. Entrevista com Ana Maria Gonçalves. Correio Nagô. (S/D). Disponível em: <http://correionago.com.br/portal/relacao-entre-racismo-e-afetividade-e-temade-curso-a-ser-ministrado-por-ana-maria-goncalves/>. Acesso em 20 jan. 2018.

IMBERNÓN, Francisco. Formação continuada de professores. Porto Alegre: Artmed 2010.

LIMA, Walter Matias. Uma pequena apresentação. In: NETO, José da Veiga Neto. (Org.) Fundamentalismo e Educação. Belo Horizonte: Autêntica. 2009. p. 13-16.

MUNANGA, K. (Org.). Superando o racismo na escola. Brasília: Ministério da Educação, 2005.

OLIVEIRA, Iolanda. Raça, currículo e práxis pedagógicas. População negra e a educação escolar. Cadernos PENESB. n.7. Niterói: Quartet/EdUFF, 2006. p. 41-67.

; Educação para as relações raciais: Composição curricular, orientação didática e dinâmica de um curso de formação continuada para docentes da educação básica. In: PESSANHA, Marcia Maria de Jesus. (Org.). Educação e Relações Raciais. Curso Educação e Relações Étnico-Raciais. Volume 1. Niterói: CAED/UFF, 2016. p. 7-20.

SANTOS, Renato Emerson dos. O ensino de Geografia do Brasil e as relações raciais: reflexões a partir da lei 10.639. In: (Org.). Diversidade, espaço e relações étnicoraciais. O negro na Geografia do Brasil. Belo Horizonte: Autêntica, 2007. p. 21-42.

Cadernos de Pós-graduação, São Paulo, v. 17, n. 2, p. 75-97, jul./dez. 2018. 


\section{Notas:}

${ }^{1}$ Disponível em <http://portal.mec.gov.br/secretaria-de-educacao-continuada-alfabetizacaodiversidade-e-inclusao/apresentacao>. Acesso em 28/07/17.

${ }^{2}$ Fundamentalismo pedagógico é compreendido como um conjunto de princípios e valores para construção do currículo metodologias. Para melhor compreensão do conceito sugere-se a leitura: (GALLO, 2009).

3“'A Resolução 1/2004 institui as DCNERER que é aprovada pelo Parecer n 3/2004, da relatora Petronilha Beatriz Gonçalves e Silva

${ }^{4}$ Resolução número 121/1995 do Conselho de Ensino e Pesquisa do Centro de Estudos Aplicados da Faculdade de Educação da Universidade Federal Fluminense

recebido em 9 mar. 2018 / aprovado em 24 jul. 2018

\section{Para referenciar este texto:}

SOUZA, V. L.; SILVA, T. D.; MATTOS, T. P. A formação docente continuada para as relações étnico-raciais no Rio de Janeiro: a experiência do programa de estudo sobre o negro na sociedade brasileira (PENESB/UFF). Cadernos de Pós-graduação, São Paulo, v. 17, n.2, p. 7597, jul./dez. 2018. Disponível em: < https://doi.org/10.5585/cpg.v17n2.8456>. 


\title{
Cadernos
}

e-ISSN: 2525-3514

DOI: $10.5585 /$ cpg.v17n2.10315

\section{OS SABERES E FAZERES DAS CRIANÇAS QUILOMBOLAS MARAJOARA-SAlvaterra-PARÁ}

\author{
THE KNOWLEDGES AND PRACTICES OF QUILOMBOLA MARAJOARA \\ CHILdRen - SAlvaterra - Pará
}

\begin{abstract}
Erica de Sousa Peres
Mestre em Educação pela Universidade do Estado do Pará. Docente da Secretaria de Educação do Pará. Pará - PA - Brasil ericaperes_22@yahoo.com.br

Nazaré Cristina Carvalho Doutora em Educação Física pela Universidade Gama Filho. Professora Adjunta da Universidade do Estado do Pará. Pará - PA - Brasil n_cris@uol.com.br
\end{abstract}

\begin{abstract}
Resumo: O texto apresenta uma análise dos saberes e fazeres de crianças quilombolas marajoaras da Vila de Mangueira, "o quilombo-mãe”, considerado um importante território negro na Amazônia Marajoara. Assim, tivemos como navegantes quinze crianças que conduziram o "mergulho" nos saberes da cultura quilombola a partir do seu brincar e de suas vivências. Estabeleceu-se um diálogo com a "Pedagogia da Atenção", que possibilitou desvelar saberes e processos educativos peculiares que permeiam a infância negra da Amazônia, em seguida, destacou-se a importância de ouvir as narrativas de meninos e meninas com o objetivo de compreender os seus modos de aprender os saberes advindos de suas vivências. Práticas essas que se manifestam espontaneamente na vida cotidiana, por meio de interações. Diante disso, percebemos a inserção de crianças na dinamicidade e na complexidade do contexto social da comunidade remanescente de quilombo, bem como as suas atuações no trabalho de preservação das tradições da comunidade.
\end{abstract}

Cadernos de Pós-graduação, São Paulo, v. 17, n. 2, p. 99-119, jul./dez. 2018. 
Palavras-chave: Crianças Quilombolas. Saberes. Educação.

\begin{abstract}
The text presents an analysis of the knowledges and practices of quilombola Marajoara children from the village of Mangueira, "the mother quilombo", considered an important black territory in the marajoara amazon. Thus, we had as navigators fifteen children who led the "diving" into the knowledge of the quilombola culture starting from their play and their experiences. A dialogue was established with the "Pedagogy of Attention", which made it possible to uncover the peculiar educational processes that permeate the black childhood of amazon, then, there was emphasized the importance of listening to the narratives of boys and girls in order to understand their ways of learning the knowledge that comes from their experiences. Practices that manifest themselves spontaneously in daily life, through interactions. In view of this, we noticed the insertion of children in the dynamicity and complexity of the social context of the remaining community of quilombo, as well as their actions in the work of preserving the traditions of the community.
\end{abstract}

Keywords: Quilombola children. Knowledges. Education.

\title{
Introdução
}

presente artigo baseia-se na pesquisa de mestrado realizada no Pro-
grama de Pós-Graduação em Educação, da Universidade Estadual do Pará (UEPA), no período de 2016-2018. Com a pesquisa buscamos analisar os saberes da cultura quilombola marajoara a partir do brincar de crianças e de suas vivências, uma vez que as consideramos produtoras de uma cultura que influencia e é influenciada pelo contexto em que vivem. Em vista disso, consideramos essas crianças como sujeitos "produtores de cultura", ou seja, protagonistas de sua própria história, como bem reitera Conh (2005, p. 35):

As crianças não são apenas produzidas pelas culturas, mas também produtoras de cultura. Elas elaboram sentidos para o mundo e suas experiências compartilhando plenamente de uma cultura. Esses sentidos têm uma particularidade, e não se confundem e nem podem ser reduzidos àqueles elaborados pelos adultos. 
Nessa perspectiva, são crianças que compartilham experiências e vivências entre si e com os adultos, criam sentidos e significações particulares para os momentos vividos, assim como produzem representações simbólicas para suas brincadeiras e para seu o convívio, isto é, para o seu cotidiano. Por essa mesma lógica, Quinteiro (2009) destaca que a criança é um ser social que constitui mediações simbólicas, quer sejam pelos gestos, pelas brincadeiras, pelo faz-de-conta, quer seja pela linguagem em suas diversas manifestações, e tais mediações, por sua vez, são constitutivas do próprio ser humano.

Em conformidade com essa postura, as crianças quilombolas marajoaras são capazes de constituir suas "mediações simbólicas", e, assim, apresentam o mundo e a si mesmas. A partir do brincar que se constroem na coletividade, e dessa maneira, elas ressignificam o universo em que em vivem, isto é, demonstraram como a vivência lúdica integra o cotidiano da Vila de Mangueira, pois propicia uma reflexão sobre a realidade delas. Conforme a disposição das árvores, jogam seu futebol, utilizam elementos da natureza como brinquedo e/ou parte das brincadeiras, fazem da maré um local propício e divertido para as brincadeiras.

Notamos que a ludicidade se faz presente nas vivências cotidianas das crianças quilombolas marajoaras, como fantasia, imaginação e sonhos que se constroem como um labirinto de teias urdidas, com materiais simbólicos que são próprios da infância quilombola. No entendimento de Santin (2002, p.16) a ludicidade é uma "tessitura simbólica fecundada, gestada e gerada pela criatividade simbolizadora da imaginação de cada um".

Podemos dizer que a chamada "tessitura simbólica" expressa no lúdico se revela no cotidiano das crianças quilombolas marajoaras principalmente, quando elas ocupam esse território étnico com suas brincadeiras, suas capacidades de criar, imaginar e sonhar, propiciando práticas educativas que se materializam em diversos saberes. 


\section{$1 \mathrm{Um}$ breve contexto da comunidade remanescente de quilombo Vila de Man- gueira-Salvaterra-Marajó-Pará}

A comunidade remanescente de quilombo Vila de Mangueira localiza-se na mesorregião da ilha do Marajó. De acordo com dados do IBGE possui 442 moradores e representa 17\% da população do município de Salvaterra. A formação histórica dessa comunidade, conforme relatos orais, deu-se com a chegada dos negros escravizados que vinham fugidos das fazendas de Soure e nesse território encontraram abrigo, povoando e formando famílias que, posteriormente, foram se espalhando pela região, dando origem a outras comunidades remanescentes de quilombos.

Segundo as informações colhidas em estudos relacionados a quilombos marajoaras, e também com pessoas pertencentes às comunidades do entorno de Mangueira, o mito de origem das comunidades remanescentes de quilombo de Salvaterra está sempre ligado a alguém que veio da Vila de Mangueira e que se instalou em outra terra formando outro quilombo. Assim, esta figura atua como o elo entre todos os outros quilombos, sendo denominada de "quilombo-mãe"

1 , isto é, aquele que gerou todos os outros.

A comunidade remanescente de quilombo Vila de Mangueira pode ser considerado o primeiro quilombo do município de Salvaterra, dado que é ressaltado pela oralidade e pela memória. Dessa forma, essa comunidade se estabelece enquanto mito de origem preservado na memória dos quilombolas. Essa informação vem ao encontro do pensamento de Le Goff (1992) ao afirmar que a memória é a propriedade onde se conserva certas informações. Percebe-se que é a partir desta propriedade que as informações sobre a origem ou a história do lugar são transmitidas de geração em geração.

Por sua vez, a comunidade remanescente de quilombo Vila de Mangueira possui seu território certificado junto ao órgão responsável (Fundação Cultural Palmares). 
De acordo com este órgão, a abertura do processo de certificação da comunidade ocorreu no ano de 2011. Contudo, a comunidade ainda aguarda o processo de titulação da terra pelo Instituto Nacional de Colonização e Reforma Agrária - INCRA, na vigência do Decreto n. 4.887/2003.

Vale ressaltar que geograficamente, a Vila de Mangueira se subdivide em pequenas comunidades contidas num só "território étnico", que são formadas por lotes de terras que agregam famílias, que inclusive se utilizam de nomes diferenciados, tais como: Mangueira, São João, Salvar, Nascimento, Divindade, Mucajá e Vila Pereira, como se fossem pequenos bairros. Conforme Anjos (2010), território étnico seria o espaço construído, materializado a partir das referências de identidade e pertencimento territorial. Geralmente, sua população tem um traço comum.

Desse modo, esse "território étnico" evidencia a presença negra na Amazônia Marajoara, que resiste ao tempo e se destaca por ser considerada a primeira e a maior comunidade quilombola do município. Mediante a este contexto, problematizar os saberes do brincar a partir das vivências de crianças quilombolas do Marajó perpassa por uma concepção de que os saberes culturais são construídos e ressignificados pelos próprios sujeitos em seu cotidiano.

Assim, as crianças podem ser vistas como sujeitos que ressignificam sua vivência e trazem e/ou constroem saberes, haja vista que estão envolvidas num território onde educação e a cultura se entrelaçam, situação que não pode ser desconsiderada pelo contexto educacional. Diante disso, nossa pesquisa visa contribuir para que as crianças sejam sujeitos ativos e autônomos de sua história, tendo em vista que, quando se propõe pesquisar a partir da perspectiva da criança, permite-se que está se desvele a partir do seu brincar, já que o lúdico é algo vital e primordial para o desenvolvimento infantil.

Posto isso, pretendeu-se colaborar com o conhecimento em torno de uma história que foi silenciada pela história oficial, que é a história do povo negro que aportou 
na Amazônia Marajoara, e assim conferir um direito à voz daqueles que ficaram à margem, no sentido de desvelar "o que não foi dito", mas ainda assim, constitui socialmente, historicamente e culturalmente “o ser amazônico". Segundo a Fundação Cultural Palmares2, o estado do Pará é o quarto estado com o maior número de comunidades quilombolas. Ademais, a 3Malungu (2006) destaca que o Pará concentra o maior número de comunidades quilombolas já titulados4, sendo um dos estados pioneiros a reconhecer a importância dessas comunidades enquanto povos tradicionais que se caracterizam pelo pertencimento da terra, laços de parentesco e apropriação do território.

Isto evidencia e marca a presença negra nesse recorte amazônico que é o território marajoara, que ainda hoje resiste, luta e é representado pela existência de diversas comunidades quilombolas e inúmeras famílias de afrodescendentes que compõem a população marajoara. Nessa perspectiva, reconhecer e valorizar a contribuição negra para a Amazônia é imergir em um amplo espaço de pesquisa e análise, que ajuda a elucidar as contribuições do povo negro na Amazônia.

Vale destacar que este objeto de pesquisa se ancora na Lei n. 10.639/03, que torna obrigatório o ensino de história e cultura africana e afrodescendente, dentro desse viés, centramos no recorte de desvelar os saberes do brincar de crianças quilombolas marajoaras, considerando que o povo negro contribuiu e contribui significativamente para a história social da Amazônia Marajoara. Assim, ressaltar a voz da criança envolta na etnicidade expressa nos quilombos possibilita que compreendamos através de seu brincar e de suas brincadeiras, importantes aspectos da cultura quilombola marajoara.

O aprendizado com as crianças da Vila de Mangueira, permitiu-nos compreender que elas precisam ser ouvidas, pois, ainda que pequenas, contam com muitas experiências, é nesse sentido que suas vozes devem ser consideradas como um dado relevante, pois compreendem e analisam de forma significativa as vivências cotidianas do contexto em que vivem. 


\section{A Travessia Metodológica e o Diálogo com as crianças}

A travessia metodológica corresponde aos caminhos que delineamos para compreender os saberes presentes nas vivências lúdicas das crianças quilombolas marajoaras, tendo como eixo central o olhar da própria criança. Para isso, fez-se necessário aguçarmos a sensibilidade para alcançar a sapiência e a perspicácia das crianças e assim também nos abrirmos para o aprendizado com elas e junto delas.

Nesse sentido, foi preciso compreender os diferentes elementos e/ou situações que se apresentam no decorrer da pesquisa, já que o trabalho com as vozes de crianças, na acepção de Cruz (2008, p. 13) significa "buscar formas de ouvir as crianças, explorando as múltiplas linguagens, tem como pressupostos a crença de que elas têm o que dizer e o desejo de conhecer o ponto de vista delas" Baseados nesse "desejo de conhecer o ponto de vista delas", foi imprescindível a escolha teórica, epistemológica e metodológica que propiciou compreender e analisar o universo infantil em seus próprios termos, em outras palavras, em seus espaços de vivência.

Centrados nessa perspectiva, buscamos compreender a infância a partir da percepção de uma sociologia da infância, para isso estabeleceu-se um diálogo com os seguintes autores: Corsaro (2011), Alves (2014), Quinteiro (2009) e Conh (2005). No âmbito da cultura e ludicidade, enveredamos pelos estudos de Geertz (2012), Thompson (1995), Santin (2002), Huizinga (2012), Caillois (1990) e Brougére (2000). E no processo de análise dos dados buscamos aproximação bibliográfica com a "Pedagogia da Atenção”, partindo de Brandão (2002), Martinic (1994) e Tim Ingold (2010), nomes fundamentais para a compreensão os modos de saber e fazer, e, nesse caso, auxiliando-nos a compreender o universo lúdico das crianças da Vila de Mangueira. 
Como o estudo considera as crianças quilombolas como sujeitos ativos da pesquisa, em um primeiro momento, propusemos um exercício de ouvir as suas narrativas, ao mesmo tempo em que a observação de suas vivências lúdicas foi considerada essencial para a coleta de dados. A observação participante foi de suma importância, pois o tempo que estivemos com elas propiciou o envolvimento e confiança delas no sentido de permitir que vivenciássemos o seu cotidiano, partilhando de suas experiências. Nesse sentido, vale ressaltar que a pesquisa com crianças é instigante e inspiradora, pois elas têm muito a dizer e a ensinar, sobretudo no que tange seu próprio bem viver e de sua comunidade, precisamos escutá-las com mais frequência em nossas pesquisas para assim reverenciar a leveza de quem tem no lúdico a sua essência.

Vale ressaltar que como se trata de uma pesquisa com crianças, os aspectos éticos foram mantidos, de acordo com a Resolução n.196/96 da Organização Mundial da Saúde - OMS, resguardando os nomes dos sujeitos envolvidos, além da solicitação de assinatura do TCLE pelas crianças e seus responsáveis. Diante disso, a pesquisa foi encaminhada ao Comitê de Ética, e tendo sido aprovada.

\section{O cotidiano lúdico das crianças quilombolas marajoaras}

O brincar nas vozes das crianças assume uma função significativa em suas vidas, demonstram que suas infâncias são marcadas como tempo de brincar. Nesse sentido, quando indagadas sobre o que é brincar, responderam:

Brincar para mim é legal, é divertido, é ser livre, é poder sair para correr (Kelé, 10 anos).

Ficamo muito alegre nas brincadeiras, a gente ri, é muito bom, bom mermo (Sarubé, 10 anos).

Eu brinco porque é divertido (Tia Coconda, 09 anos).

Gosto de brincar com meus amigos porque é legal (Noca, 09 anos)

Cadernos de Pós-graduação, São Paulo, v. 17, n. 2, p. 99-119, jul./dez. 2018. 
Eu brinco de bola, de um monte de brincadeira legal (Biel, 09 anos).

A gente brinca junto, um vai chamar o outro pra brincar, é muito legal (Cai Cai, 09 anos).

Eu brinco para me divertir, o cara ri muito com as brincadeiras que a gente brinca (Lily, 09 anos).

Brincar é se divertir (Jarubá, 10 anos).

Ah! Brincar é se divertir, é rir, é se distrair, é bom (Catú, 10 anos)!

Percebemos nas falas das crianças que o brincar está relacionado à diversão, ao lazer, ao prazer de estar com os amigos, a jogar futebol, a jogar baralho. Demonstram, assim, que o brincar para elas é uma atividade prazerosa que se realiza na coletividade, isto é, que existente na co-dependência do outro.

Ao ressaltarem a diversão e o lazer como sensações vividas pelo brincar, resgatam o dizer de Caillois (1990) quando considera que imagens e símbolos se envolvem nas manifestações lúdicas, associando simultaneamente alegria e divertimento. Além disso, no que tange ao simbólico, Geertz (2012) e Thompson (1995) convergem suas ideias, considerando a questão simbólica como reveladora das construções culturais presentes nos fenômenos.

Assim, as crianças tornam-se brincantes e ocupam os espaços da comunidade e o seu tempo-infância, realizando brincadeiras de acordo com a sua realidade local. Com essa perspectiva, retoma Brougère (2000), quando ressalta a brincadeira como um processo de relações interindividuais, portanto cultura, já que parte dos elementos que as crianças encontram no seu ambiente imediato, em parte estruturado por seu meio, são usados para se adaptar às suas capacidades. 
Destarte, as manifestações lúdicas das crianças da Vila de Mangueira convergem enquanto práticas culturais, visto que elas em suas falas elaboram um discurso simbólico sobre suas vivências lúdicas, nas quais os significados são atribuídos a partir de suas interpretações culturais. Assim, ao longo da permanência na comunidade, foi possível observar diferentes formas de brincar entre as crianças e elas relataram várias outras possibilidades de diversão.

Também é visível que a liberdade e a espontaneidade se fazem presentes no cotidiano das crianças da Vila de Mangueira, e as brincadeiras perpassam os diversos momentos da vida cotidiana delas. Desse modo, as crianças inventam o seu brincar, decidem as regras dos jogos e ressignificam a natureza conforme a necessidade das brincadeiras, criando brinquedos diversos. Nesse contexto, o brincar e as brincadeiras são aspectos fundamentais para o processo de socialização e vivência da infância singular dos quilombos marajoaras.

\section{Os Saberes e Fazeres do brincar das crianças da Vila de Mangueira-Salvaterra- Marajó-Pará}

Apresentamos aqui uma educação que se contrapõe à hegemonia do saber escolarizado, considerando processos educativos que se articulam com as manifestações lúdicas vivenciadas pelas crianças quilombolas marajoaras em seu cotidiano, situando, assim, este estudo do outro lado da linha abissal.

De acordo com Santos (2007), o pensamento moderno é abissal, pois, no campo do conhecimento, o pensamento abissal consiste na concessão à ciência moderna, do monopólio da distinção entre o verdadeiro e o falso, isto é, à luz da modernidade distingue o conhecimento que deve adentrar a escola e ser legitimado, e aquele que fica às margens, excluído da educação escolar. 
Dito isso, optamos por apresentar aqui uma educação que pretende romper com a tradicional valorização do saber científico presente na escola, e passa a considerar saberes significativos para o cotidiano dos sujeitos, pois se alinham com a realidade e valorizam seus modos de pensar, fazer e viver, e se constituem enquanto práticas educativas para além da escola. Nas falas que se seguem os intérpretes expressam um conjunto de diferentes saberes, porém muito significativos para o seu contexto local.

A cidreira, o boldo, a erva-doce, o capim santo a gente usa pra fazer chá, é bom para dor de cabeça, pra barriga, põe a água pra ferver, borbulha e quando borbulha tira do fogo e põe as folha e abafa, tá pronto, mas a gente bebe quando não tem café também (Catú, 10 anos)!

Eu aprendi a nadar com o Teta. Ele mostra como é, a gente fica olhando, vendo ele fazer, depois ele joga a gente no meio da maré, aí a gente sai nadando (Cai Cai, 09 anos).

A gente fica olhando a madrinha fazer a comida, ela manda olhar bem, ver como faz tudo direitinho, depois, no outro dia, ela manda eu fazer e dar pr'as meninas, porque aí eu já aprendi e posso ensinar pra elas. Eu sei fazer arroz, feijão, cuidar do peixe, fazer mingau de caramujo, gosto de ajudar a madrinha, acho legal (Lelé,12 anos)!

Percebemos nesses depoimentos o trânsito de muitos saberes, conhecimentos sobre as ervas e o modo de prepará-las. Segundo Catú, elas têm duas utilidades: servem tanto para curar algum problema como dor de barriga, quanto para substituir o café. Cai Cai e Lelé demonstram a maneira como aprenderam a nadar e a cozinhar, respectivamente.

As falas das crianças corroboram um processo de aprendizado diferenciado do escolarizado. Trata-se de uma aprendizagem vivenciada na prática, e, como tal, expressam-se exatamente como são aprendidas. As crianças da Vila de Mangueira convivem com o que Medaets (2011, p. 10) denomina de "saberes que não são ditos, informados, 
mas sim vividos, mesmo que através da observação". É através da experiência continuada, em primeiro lugar, como observador ativo.

Como observadores ativos, as crianças quilombolas aprendem "as coisas do mundo" de acordo com o "modo de ensinar" específico do contexto em que vivem. Nessa perspectiva, Brandão (1995) assinala que, conforme o tipo de saber, existe um modo de ensinar. Assim:

Tudo o que é importante para a comunidade, e existe como algum tipo de saber, existe também como algum modo de ensinar. Mesmo onde ainda não criaram a escola, ou nos intervalos dos lugares onde ela existe, cada tipo de grupo humano cria e desenvolve situações, recursos e métodos empregados para ensinar às crianças, aos adolescentes, e também aos jovens e mesmo aos adultos, o saber, a crença e os gestos que os tornarão um dia o modelo de homem ou de mulher que o imaginário de cada sociedade - ou mesmo de cada grupo mais específico, dentro dela - idealiza, projeta e procura realizar (BRAND ̃̃O, 1995, p. 22, grifo do autor).

Assim, elas aprendem o que é importante para a comunidade onde vivem a partir de algum saber e com um modo de ensinar peculiar. $\mathrm{O}$ desenvolvimento e a articulação desses saberes são significativos e relevantes para a práxis e o bem viver dessas crianças. Dito de outra maneira, os saberes que circulam nas vivências das crianças explicitam práticas cotidianas necessárias para a vida e/ou para a sobrevivência. Isso pode ser percebido na voz dos respectivos entrevistados: Tia Coconda, Biel e Catú, ao dialogarem sobre os seus saberes acerca da maré, quando indicavam que devíamos ir naquele momento para o rio:

A gente sabe quando a maré tá viva, é quando encher, aí é muito bom pra brincar, pra nadar. Quando ela tá morta, água morta, é quando seca, o Teta que diz pra gente, ele que ensina, pra nós saber (Tia Coconda, 09 anos). 
Lá na maré não dá pra brincar muito no fundo, ela puxa, eu sei porque eu já vi puxar. Meu tio Teta ensina à gente as coisas do mundo, ensina a gente a se defender da maré quando ela tá malvada (Biel, 09 anos).

Quando vai encher, a gente já sabe, porque a gente já aprendeu a lidar com a maré e aí a gente vai tudinho pra lá porque vai ser bom de brincar, nadar, pescar, ficar de boa (Catú, 10 anos).

Fica vidente nos trechos das falas acima a relação estabelecida com a maré, algo que está para além do brincar, embora este seja um dos lugares preferidos para essa prática. A maré é também o lugar de aprender acervos do cotidiano de uma vila de pescadores. Ademais, o modo de aprender as "coisas do mundo" se conecta com a figura do Seu Teta, que se faz presente em muitos momentos na voz das crianças, principalmente quando se trata da maré, evidenciando que o modo de aprender perpassa pela oralidade. A troca de saberes se dá, sobretudo, pela vivência e/ou encontro de gerações.

A percepção de mundo da comunidade é repassada a partir de saberes populares transmitidos pela oralidade e pelo convívio social. Para Tim Ingold (2010), a contribuição que cada geração dá à seguinte não é um suprimento acumulado de representações, mas uma educação da atenção. É preciso estar atento para aprender, pois o modo de aprender está atrelado à observação, ao olhar o outro fazer para assim aprender. Evidenciamos que as crianças da Vila de Mangueira observam atentamente os saberes difundidos através da oralidade pelos mais velhos, logo, os saberes vão se perpetuando no seu modo de agir e de pensar o mundo.

Dessa forma, os saberes tornam-se intrínsecos ao contexto vivenciado pelas crianças. Diante disso, o saber é construído na vida cotidiana, no ver e no fazer, e assim, vão se integrando ao cotidiano e se relacionando com a educação, com a realidade e com as particularidades de uma comunidade quilombola. Para Martinic (1994), a sabe- 
doria popular refere-se ao acervo de conhecimento produzido e acumulado historicamente pelos grupos sociais e permitem aos sujeitos relacionar suas experiências e objetivações, que encontram sentido nas práticas do grupo em que estão inseridos.

Desta feita, a educação pode ser encontrada nos diversos saberes populares. $\mathrm{O}$ processo de ensino-aprendizagem perpassa por diversos aspectos; entre os quais, destacamos a "educação da atenção", a qual é encontrada no cotidiano das crianças da Vila de Mangueira, conforme se observa nas passagens seguintes:

A gente tem que prestar a atenção para aprender, ficar olhando bem, não tirar o olho, porque senão queima a panela, aí estraga tudo e a gente fica sem comer, com fome (Jaburá,10 anos).

Meu pai que me ensinou a jogar bola. Ele mandou eu olhar ele jogando, eu fiquei só olhando bem, depois eu comecei a jogar, hoje eu sou bom de bola e ensino também, às vezes [risos] (Kelé,10 anos).

Eu vou para pesca e às vez pra fazenda. Meu pai leva pra ficar olhando ele fazer as coisas, eu olho bem pra aprender, e depois eu ajudo ele nas coisas do trabalho dele. E eu acho legal e divertido ir pra lá (Sarubé,10 anos).

Nas vozes das crianças, verifica-se um processo de ensino-aprendizagem que depende da atenção ao que acontece no entorno, e assim se aprende a cozinhar, a jogar bola e a pescar. A aprendizagem é baseada na atenção, na observação, no olhar o fazer do outro e posteriormente no exercício do fazer e do praticar, e esse processo se aplica tanto para se aprender as brincadeiras, quanto para atividades domésticas e atividades laborais comuns no contexto das comunidades quilombolas marajoaras.

Esse dado se aproxima da assertiva do antropólogo Tim Ingold (2010), em que o processo educacional envolve uma "educação da atenção", verificada no momento de "aprender a sintonizar o momento de sua atenção ao movimento da ação do outro 
que nos cerca". A educação proposta pela experiência considera o local de pertencimento e a vivência do sujeito, bem como a maneira como aprende e ensina, tendo na observação e na atenção os instrumentos de aprendizagem. Dessa forma, é necessária uma observação minuciosa e atenta para, assim, aprender o que o outro ensinar em seu fazer prático.

Considerando o brincar e as brincadeiras como espaço educativo, que propiciam o compartilhamento de saberes e a construção de processos e práticas educativas, Oliveira (2010, p. 87), quando se refere à interação, afirma que "as crianças, ao brincarem [...], interagem com seus pares construindo espaço-tempo de sociabilidade e aprendizagem por intermédio do qual se localizam e se posicionam no mundo social local”.

Tendo em vista o posicionamento social e local desses sujeitos, descrevemos alguns saberes protagonizados pelos intérpretes deste estudo. E com o intuito de dinamizar apresentamos no quadro abaixo, analisa-se o tipo de educação que se insere no contexto desses saberes. Nesses moldes, é importante mencionar que a circulação desses saberes se coaduna com as manifestações lúdicas das crianças quilombolas marajoaras residentes na Vila de Mangueira.

\section{Quadro dos Saberes e práticas educativas das crianças quilombolas marajoa-} ras

\begin{tabular}{|c|c|c|c|}
\hline O Saber & $\begin{array}{c}\text { Como o saber é } \\
\text { compartilhado }\end{array}$ & Processos e práticas educativas & Educação que o saber está associado \\
\hline \multirow{2}{*}{ SABERES LÚDICOS } & Oralidade & Brincar & \\
& Observação & Brincadeiras & Educação pela ludicidade e pela arte \\
& Orientação & Prática & Teatro (repetição das falas e representação dos \\
& Repetição & personagens) & \\
\hline
\end{tabular}

Cadernos de Pós-graduação, São Paulo, v. 17, n. 2, p. 99-119, jan./jun. 2018. 


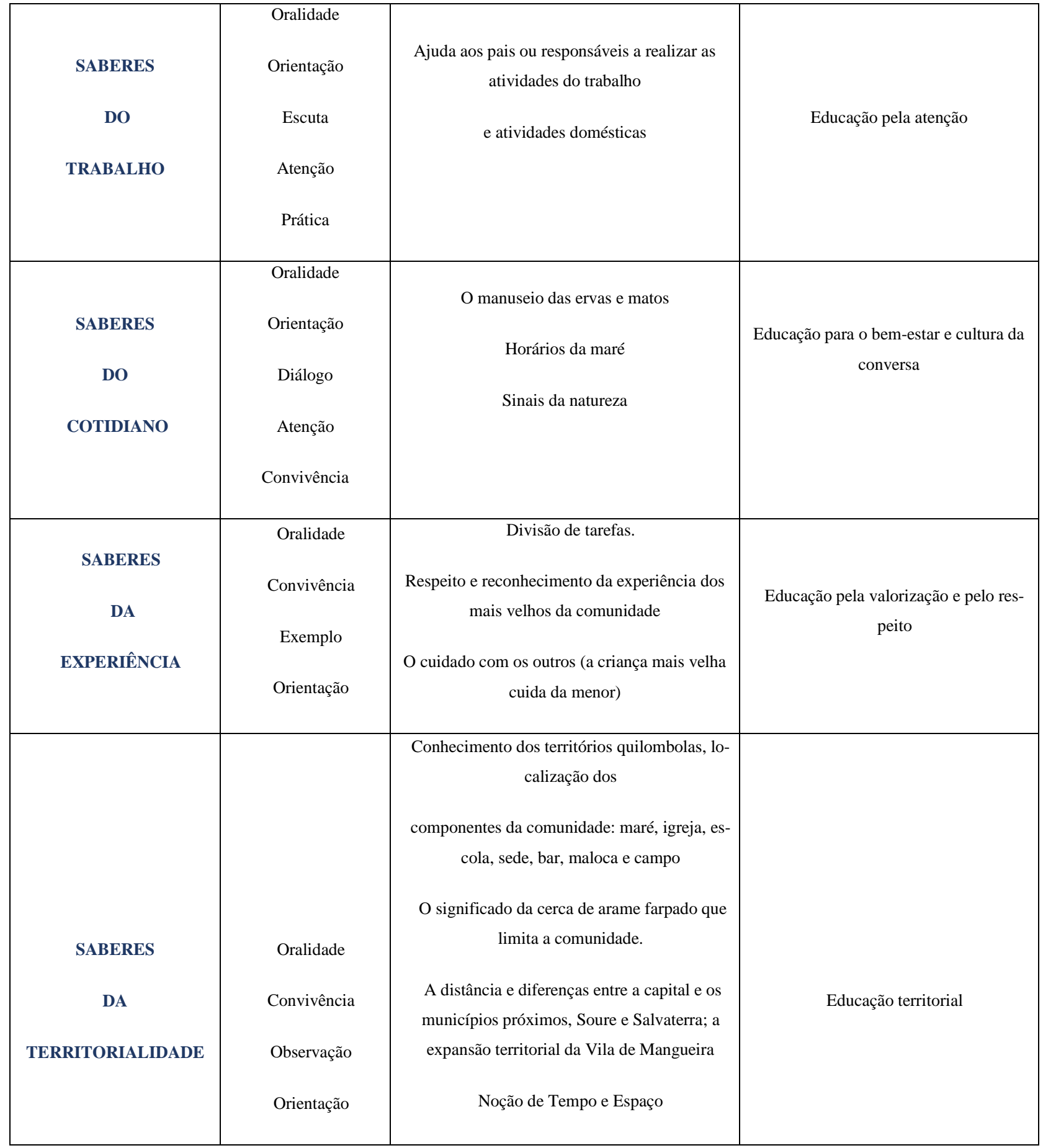




\begin{tabular}{|c|c|c|c|}
\hline SABERES & Oralidade & & \\
RELIGIOSIDADE & Observação & $\begin{array}{c}\text { Rezas; ladainhas; informações sobre práticas e } \\
\text { costumes religiosos }\end{array}$ & Educação religiosa \\
& Orientação & & \\
\hline
\end{tabular}

Fonte: Análises feitas nesta pesquisa pela autora

Conceber a educação na perspectiva dos saberes é legitimar os conhecimentos que se constroem nas práxis cotidianas. Assim, para Brandão (2002), a educação é cultura, pois o estudioso considera como prática educativa tudo o que o homem constrói, como seus saberes, significados e experiências de vida.

Nesse panorama, os saberes protagonizados pelas crianças nas suas vivências cotidianas compreendem práticas educativas que evidenciam uma educação que não se restringe apenas ao espaço da escola. Assim, a "educação aparece sempre que surgem formas sociais de condução e controle da aventura de ensinar - e - aprender” (BRANDÃO, 1995, p. 26).

Com base nesses ensinamentos vivenciados nas práxis cotidianas, identificamos cinco saberes: lúdicos, do trabalho, do cotidiano, da hierarquia, da territorialidade e da religiosidade, os quais se relacionam com diferentes tipos de educação, como Educação pela ludicidade e pela arte, "Educação pela atenção", Educação para o bem-estar e a cultura da conversa, Educação pela valorização e pelo respeito, Educação territorial e Educação religiosa. Nesses termos, reconhecer esses saberes provenientes das vivências das crianças quilombolas marajoaras é considerar um processo de ensino-aprendizagem que educa para além dos conteúdos cientificistas: educa para a vida.

Portanto, as manifestações lúdicas das crianças quilombolas da Vila de Mangueira se configuram como um espaço educativo pleno, onde o processo de ensinoaprendizagem se constitui em estar atento para aprender, e assim saber e fazer. Esses 
modos de ser, de aprender e de fazer foram revelados e protagonizados pelos intérpretes da pesquisa.

\section{Conclusão}

Ao longo desse trabalho percebemos que o conceito de educação acaba sendo ampliada, materializando o que escreve Brandão (2002), para quem “educação é cultura", e com isso reconhece a urgência de repensar e ressignificar os diferentes processos educativos. Assim, apresentamos neste estudo, saberes que concebem diferentes espaços e modos de aprendizagem, tais como os saberes lúdicos, saberes do trabalho, saberes do cotidiano, saberes da hierarquia, saberes da territorialidade e saberes da religiosidade.

Diante do exposto, entendemos claramente a necessidade de considerar a dinâmica de cada grupo social, respeitar suas especificidades e modos singulares de vida, pois estes, em grande parte, são ligados à cultura e às tradições desses grupos. Nesse sentido, notamos a necessidade e a urgência em desconstruir o paradigma hegemônico educacional das teorias ocidentais. Isto não significa que a escola não seja importante, sabemos que ela é relevante e de suma para os sujeitos, porém, não podemos mais limitar a educação a apenas esse espaço.

Tendo em vista que o educar extrapola os muros da escola e ocupa todas as dimensões das vivências das crianças quilombolas marajoaras. Nessa perspectiva, é fundamental visibilizar novas epistemologias, para assim compreender as identidades, as diferentes formas de viver, pensar, ensinar, aprender e educar, sobretudo, pensar em propostas de ensino que atendam as reais necessidades de sujeitos que vivem em território étnicos marcados pela luta pela terra e pela resistência em manter viva sua história, como é o caso das crianças da Vila de Mangueira. 


\section{Referências}

ALVES, Laura Maria Silva Araújo. A infância em construção: as fontes de investigação. In: ARAÚJO, Sonia Maria da Silva; ALVES, Laura Maria Silva Araújo; BERTOLO, Sônia de Jesus Nunes (Org.). Pesquisa e educação na Amarônia: reflexões epistemológicas e políticas. Belém: EDUEPA, 2014.

ANJOS, R. S. A. O Brasil africano: geografia e territorialidade. Brasília: CIGACESPE/UnB, 2010.

BRANDÃO, C. R. Educaşão como cultura. São Paulo: Mercado das Letras, 2002.

BROUGÈRE, Gilles. Brinquedo e cultura. São Paulo: Cortez, 2000.

CAILLOIS, Roger. Os jogos e os homens: a máscara e a vertigem. Lisboa: Ed. Cotovia, 1990.

COHN, Clarice. Antropologia da criança. 2. ed. Rio de Janeiro: Jorge Zahar Ed., 2005.

CORSARO, Willian A. Sociologia da infância. Porto Alegre: Artmed, 2011.

CRUZ, Silvia H. V. A criança fala: a escuta de crianças em pesquisas. São Paulo: Cortez, 2008.

GEERTZ, C. A interpretação das culturas. Rio de Janeiro: TLC, 2012.

HUIZINGA, Johan. Homo Ludens: o jogo como elemento da cultura. São Paulo: Perspectiva, 2012. 
INGOLD, Tim. Da transmissão de representações à educação da atenção. Educação, Porto Alegre, v. 33, n. 1, p. 6-25, jan./abr. 2010. Disponível em: < http://revistaseletronicas.pucrs.br/ojs/index.php/faced/article/view/677/4943>. Acesso em: 16 jan. 2018.

LE GOFF, J. História e memória. 2. ed. Campinas, SP: Ed. UNICAMP, 1992.

MALUNGU. Nova cartografia social da Amazônia: Quilombolas da ilha de Marajó Pará. Belém: Coordenação Estadual Associações de Remanescente de Quilombos do Estado Pará - MALUNGU, 2006.

MARTINIC, Sergio. Saber popular e Identidade. In: GADOT'TI, Moacyr; TORRES, Carlos Alberto (Org.). Educação popular: utopia latino-americana. São Paulo: Cortez; Edusp, 1994.

MEDAETS, Chantal. “Tu garantes?”: Reflexões sobre a infância e as práticas de transmissão de aprendizagem na região do baixo-tapajós. In: CONGRESSO LUSOAFRO-BRASILEIRO DE CIÊNCIAS SOCIAIS, DIVERSIDADES E (DES) IGUALDADES, 11, 2011, Salvador. Anais ... Salvador, BA: Universidade Federal da Bahia (UFBA). 1 CD-ROM.

OLIVEIRA, Assis da Costa. Crianças Indígenas: teoria, etnografia e direitos. In: BELTRÃO, Jane Felipe; MASTOP-LIMA (Org.). Diversidade, educação e direitos: Etnologia indígena. Belém: IMECI; EDUCIMAT, 2010.

QUINTEIRO, Jucirema. Infância e educação no Brasil: um campo de estudos em construção. In: FARIA, Ana L.G. de; DEMARTINI, Zelia de B. F; PRADO, Patrícia D. (Org.). Por uma cultura da infância: metodologias de pesquisas com crianças. Campinas, SP: Autores Associados, 2009.

SANTIN, S. Educação física: da alegria do lúdico à opressão do rendimento. 3. ed. ampl. Porto Alegre: EST Edições, 2002. 
SANTOS, B. S. A gramática do tempo: para uma nova cultura política. São Paulo: Cortez, 2007.

THOMPSON, J. B. Ideologia e cultura moderna: teoria social e crítica na era dos meios de comunicação de massa. Petrópolis, RJ: Vozes, 1995.

\section{Notas:}

${ }^{1}$ Utilizamos o termo quilombo-mãe para designar aquele que, segundo as memórias que me foram narradas por moradores de outras comunidades, foi o primeiro quilombo a ser formado em Salvaterra, sendo o refúgio inicial dos negros que fugiam da escravidão imposta nas fazendas de Soure.

${ }^{2}$ Fundação Cultural Palmares, entidade vinculada ao Ministério da Cultura (MinC).

3 Malungu é a palavra escolhida para nomear a Coordenação das Associações das Comunidades Remanescentes de Quilombos do Pará. Foi oficialmente fundada em março de 2004, como uma organização sem fins lucrativos e econômicos para representar as comunidades quilombolas do Pará

${ }^{4} \mathrm{Na}$ esfera federal, o INCRA - Instituto Nacional de Colonização e Reforma Agraria - é o órgão responsável por titular as terras de quilombo seguindo os procedimentos estabelecidos no Decreto Federal n. 4.887, de 2003, e na Instrução Normativa Incra n. 57, de 2009.

recebido em 26 ago. 2018 / aprovado em 19 out. 2018

\section{Para referenciar este texto:}

PERES, E. S.; CARVALHO, N. C. Os saberes e fazeres das crianças quilombolas MarajoaraSalvaterra-Pará. Cadernos de Pós-graduação, São Paulo, v. 17, n.2, p. 99-119, jul./dez. 2018. Disponível em: <https://doi.org/10.5585/cpg.v17n2.10315>. 


\title{
A LEI 10.639/03 E AS RELAÇÕES ÉTNICO-RACIAIS NO AMBIENTE
}

\author{
ESCOLAR: MUDANÇAS E PERMANÊNCIAS
}

\section{LAW 10.639/03 AND THE ETHNIC-RACIAL RELATIONS IN THE SCHOOL ENVIRONMENT: CHANGES AND STAYS}

\author{
Nívea Maria Araújo Santana \\ Mestra em Educação pela Universidade Estadual de Pernambuco, atualmente atua na \\ Gerência Regional de Educação Vale do Capibaribe. Pernambuco - PE - Brasil \\ nmas.wendy@gmail.com
}

\begin{abstract}
Resumo: Nos últimos anos, as mudanças trazidas pela globalização cultural e econômica, que, ao contrário do que se imaginava, vem contribuíndo para um processo cada vez mais acentuado de fragmentação das identidades e fortalecimento das heterogeneidades, assim como a maior organização dos movimentos sociais, tem levado o governo brasileiro a implementar políticas afirmativas, a fim de mitigar as graves assimetrias da nossa sociedade. Nesse contexto, trazer o debate acerca da diferença e da diversidade, buscando promover uma educação "étnico-racial positiva", tornou-se, em muitos sentidos, "dever da escola" e, consequentemente "trabalho do professor". Refletir acerca da eficácia e do alcance de tais medidas, em especial a Lei 10.639/03, leva-nos a procurar conhecer e desdobrar-se de maneira positiva em prática escolar, especialmente no que se refere ao ensino de História e a "pluralidade cultural", presentes nos PCNs.
\end{abstract}

Palavras-chave: Lei 10.639/03. Diversidade. Mudança. Escola.

\begin{abstract}
In recent years, the changes brought about by economic and cultural globalization, which, contrary to what was thought, have contributed to an increasingly pronounced process of fragmentation of identities and strengthening of heterogeneities, as well as the largest organization of social movements, has led the Brazilian government to implement affirmative action policies in order to mitigate the serious imbalances in our society. In this context, bringing the debate on difference and diversity, seeking to promote a "positive ethnic-racial" education has become, in many ways, "school duty" and consequently "teacher's job." Reflect on the effectiveness and scope of such measures, especially the Law 10.639 / 03, leads us to seek to know and unfold in a positive way school practice, especially regarding the history teaching and "cultural plurality" present in the PCNs.
\end{abstract}

Key-words: Law 10.639/03. Diversity. Change. School.

Cadernos de Pós-graduação, São Paulo, v. 17, n. 2, p. 121-140, jul./dez. 2018. 


\section{Introdução}

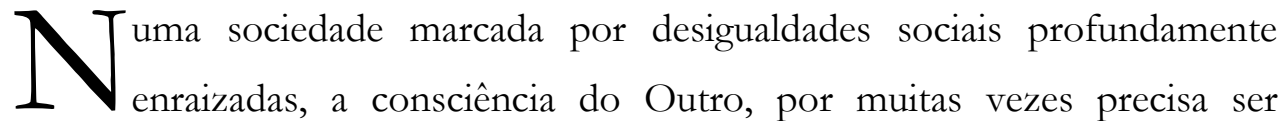
despertada por algum fator externo, uma vez que o consumismo e o individualismo ajudam a acirrar as diferenças culturais, estimulam a competição e criam novos objetos de desejo, padrões de beleza e parâmetros de sucesso numa velocidade nauseante.

Em tal contexto, aceitar e respeitar as diferenças e reconhecer a diversidade como algo positivo é parte de um exercício de reflexão e autoconhecimento que tem início quando entendemos que, a construção da nossa identidade não é um processo solitário e sim, resultado de uma relação muito estreita com as pessoas ao nosso redor, que são responsáveis por nos dar parâmetros, diante dos quais podemos moldar os limites do nosso próprio ser.

O que fica evidenciado nas discussões sobre as relações raciais e a educação, que tem mostrado a importância de se trabalhar na perspectiva de influenciar a dinâmica escolar, evitando a perpetuação e reprodução de discussos depreciadores da identidade de aluno/as, a partir do estímulo ao diálogo e a convivência com as diferenças, reelaborando significados sociamente construídos e confirmando que a prática pedagógica e os princípios culturais precisam ser continuadamente reiventadas e reinvestidas de novos sentidos.

Nessa perspectiva, procedeu-se o projeto de dissertação do Mestrado em Educação, o qual foi motivado pelas nossas observações em sala de aula e nossa inquietação quanto as diferenças e desigualdades nos espaços da escola, onde procuramos conhecer os referenciais dos professores e alunos, bem como, as relações 
que se estabelecem na prática pedagógica sobre a diversidade na sala de aula, com enfase para a presentaça dos afro-brasileiros.

Buscando, nesse ínterim, refletir até que ponto os objetivos almejados com a implantação da Lei 10.639/03, conseguiram sair do campo da "retórica" e influenciar na praxis a adoção de uma educação inclusiva, principalmente quando a euforia com relação a mesma já aferreceu e novas pautas ocupam o interesse imediato da mídia.

\section{Educação e diversidade no contexto educacional brasileiro: breve trajetória}

Nas últimas décadas conceitos como multiculturalidade e interculturalidade vem ganhando espaço nas discussões acerca da Educação em vários países do mundo, chama a atenção, porém, que isso ocorra justamente quando a instituição escolar passa por seu período de maior fragilidade, quando a sua própria relevância vem sendo questionada, fazendo com que o desafio dos educadores em relação implementação de uma educação multi-intercultural seja ainda mais acentuado, principalmente levando-se em conta as vissicitudades de cada país, uma vez que esse não é um fenômeno isolado.

No caso brasileiro, cujo sistema educacional possui uma história de acentuada hierarquização e elitização, que contribuiu para a exclusão de boa parte da população dos bancos escolares, ajudando a perpetuar o status quo das elites, a visão propedéutica e tecnicista do ensino, principalmente do Ensino Médio ${ }^{1}$, tem sido alvo de duras críticas desde sua institucionalização durante o período imperial, quando entre os poucos privilegiados que podiam ingressar nas intituições educacionais, um número ainda menor conseguia ter acesso ao Ensino Secundário².

Com fim da escravidão e após a República, a "hierarquização” intensificou-se, ganhando contornos racialistas, como podemos observar nos estudos de (ARANTES, 2014), onde podemos ver que graças a forte influência da medicina higienista, cujos 
principais expoentes bebiam, por sua vez, nas teorias raciais introduzidas no Brasil desde meados do século XIX, ocorreu uma divisão, ainda mais acentuada, entre os alunos, que passaram a ser classificados conforme as "características" do grupo racial no qual eram enquadrados:

Nesse contexto o grupo escolar representou um novo modelo de organização escolar, caracterizado pela seriação com a divisão de alunos por classes, considerando-se a idade e os níveis de conhecimentos que se pretendia fossem homogêneos. (ARANTES, 2014, p. 116).

É que nesse período (a partir da década de 1930) que, ironicamente, o mestiço, até então visto como uma mazela a ser combatida, é eleito como símbolo do Brasil, por representar o ideal da união das três raças que formaram o povo brasileiro (branco, negro e índigena), ajudando a reforçar o mito de que o país seria um modelo de democracia racial, ideia para qual as obras de Gilberto Freire - Casa Grande e Senzala (1933) iriam trazer grande contribuição, formando uma parceria com o Estado Novo (1937-1945), que possibilitou uma aliança perfeita para alimentar o imaginário social do "mito da democracia racial" e da "união das três raças".

Apenas durante a década de 1970, o processo de organização dos professores começa a se articular no interior do movimento social organizado e a escola e o ensino tradicional passam a ser alvo de críticas e contestações. A pressão exercida por esses movimentos faz com que tenha início uma política governamental voltada para “universalização da Educação”, influenciada, sobretudo pela Lei 5.692/1971³, a paritr da qual serão feitas revisões nas legislação pertinente ao ensino e iniciam-se processos de reformas dos currículos.

Tal proposta, entrentanto, acaba por trazer uma dicotomização ainda mais acentuada para o Ensino Médio, onde 
As redes públicas de ensino técnico federal e as redes estaduais como a de São Paulo, elitizadas por meio da seletividade promovida pelos "vestibulinhos" e beneficiadas com políticas que favoreciam melhores condições de trabalho e remuneração a seus professores, conseguiram promover maior qualidade no ensino do que aquela oferecida pelas escolas de ensino médio denominadas "regulares", destinadas à população trabalhadora. (BRASIL, 2013, p. 20-21).

Essa divisão entre escolas públicas e escolas privadas, por sua vez, causa um distanciamento ainda mais acentuado das condições democráticas nas escolas, onde ao contrário do que se precisava, acentua-se a "ressegregação nas escolas", uma vez que,

Para contornar esse problema [da inclusão de universalização do ensino público] as famílias ricas enviam seus filhos para escolas privadas, instituições que foram criadas geralmente fora dos centros urbanos, onde mais e mais famílias estão se mudando para espacapar da violência, guetização e a sensação de insegurança. (SANTIAGO, 2013, p. 59).

De igual modo, mesmo a Constituição de 1988 e a promulgação da LDB, bem como todas as medidas tomadas durante a década de $1990^{4}$, não vão ser capazes de trazer mudanças estruturais significativas no conceito igualdade e justiça social.

Essa dificuldade de produzir ressignificações efetivas nas relações sociais, levou Fry (2005, p.227) a afirmar que essas medidas "são usadas para fortalecer os direitos e liberdades individuais conforme o racismo e o racialismo, não representam mudanças marcantes na política antiga e estão em consonância com os ideais de 'democracia racial"”.

Assim, embora reconhecendo que a Lei $10.639 / 03^{5}$ tenha trazido mudanças significativas para o currículo da disciplina escolar História, notório, como apontam Torres e Ferreira (2014, p. 89) por “apresentar tradições curriculares consolidadas e que trazem como marca importante o protagonismo do homem branco em detrimento 
A LEI 10.639/03 E AS RELAÇÕES ÉTNICO-RACIAIS NO AMBIENTE ESCOLAR: MUDANÇAS E

PERMANÊNCIAS

ao processo vivenciado pelos africanos em nossa sociedade", acreditamos ser necessário refletir acerca do alcance e das limitações que a Lei, enquanto política afirmativa do governo brasileiro, em relação à promoção mudanças efetivas no modo como ocorrem as relações "étnico-raciais" entre os indivíduos, tendo a Escola como palco e termômetro que permite aferir a eficácia ou não de tais iniciativas.

Para tanto, partimos do princícpio que a imposição legal por si só, não é capaz de fomentar relações "etnico-raciais" positivas nem a valorização das diversas identidades dos alunos dentro das escolas, sem que haja um processo de formação dos docentes que leve a uma ressignificação da forma como os mesmos enxergam e trabalham a diversidade na sala de aula.

\section{A Lei 10.639/03 e o lugar da diferença na escola}

A busca para galgar posições no ranking de avaliações, como por exemplo, o Programa para Avaliação Internacional de Estudantes (PISA), acaba levando à conclusões duvidosas acerca da diversidade e da multiculturalidade na sala de aula, sendo esses fatores transformados em problemas e entraves as metas traçadas pelos gestores das políticas públicas; além de estimular e fortalecer o uso de práticas educacionais homogeneizantes, posto que só o resultado interessa e toda heterogeneidade dos alunos é diluida quando os mesmos são transformados em números para compor estatísticas.

Essa posição vem corroborar as reflexões tecidas por (TORRES; FERREIRA, 2014) acerca do papel da Lei 10.639/03 no currículo da disciplina escolar História, sob o argumento de que a mudança implica num processo de negociação entre o passado e o presente, o antigo e o novo ${ }^{6}$, que nem sempre será contraditório, ao contrário, a mudança pode surgir como recurso para manter a estabilidade de quem já está no 
poder, citando, como disparador para a discursão a seguinte frase de Hanna Arendt: "nenhuma mudança política parece capaz de realizar qualquer coisa de inteiramente novo” (TORRES; FERREIRA, 2014, p. 83).

Tais observações levam-nos a questionar os limites e as limitações da Lei 10.639/03, principalmente no tocante a capacidade de execução e a eficácia da mesma, uma vez que, apesar de amplamente discutida, parece que não houve uma reflexão sobre a formação adequada de professores, bem como não se percebe outros meios que possibilitem mensurar efeitos que impacte o ensino.

Por sua vez, uma leitura mais aprofundada tanto do texto da lei, quanto das Diretrizes Nacionais para Educação Básicas das Relações Étnico-Raciais (DCNEB), que vieram normatizar os princípios legais, mostra uma série de divergências com relação à utilização de categorias como “África”, "afro-brasileiro" e "negro", por exemplo, que atraem críticas vorazes, principalmente dos grupos que não concordam com a teoria do "panafricanismo" e veem o termo "África" como reducionista e homogeneizante, que não é capaz de traduzir a diversidade de povos e culturas do continente africano ou mesmo entender a influência deste na formação da sociedade brasileira

Nesse contexto, diante da diversidade de interpretações das diferenças e das apropriações de teorias, muitas delas deterministas, acaba-se quase sempre, optando-se por princípios determinados pelo mito do "embranquecimento racial" ou pela valorização do país "mestiço" da visão freyriana.

Esses exemplos ilustram algumas das contradições existentes na Lei 10.639/03 e nos remetem a (LACLAU, 2011) e o conceito de cadeia de equivalências que usa para tentar explicar o mundo pós-moderno, onde as certezas e verdades absolutas da modernidade, cederam lugar para a dúvida e as polissemias fazem com que categorias como liberdade, democracia, política e igualdade, tornem-se "significantes vazios"7. 
Sob tal perspectiva, segundo Stoer e Cortesão (1999, p. 14) “[...] o Estado se sente pressionado a legitimar aos olhos dos cidadãos a sua actuação, as suas opções e, portanto, as relações que estabelece com as diferentes instituições" e assim, podemos dizer que o texto presente na Lei é resultado desse processo de negociação, no qual determinado grupo (movimentos negros), conseguiu fazer valer suas reividicações em detrimento dos demais, inclusive, dos indígenas ${ }^{8}$.

Esse "deslocamento" do centro de poder, faz com que Estado e sociedade, sejam "forçados a fazer uma <gestão controlada>", de dois fenômenos diretamente ligados ao processo de moderniade: a desigualdade e a exclusão, pois,

[...] apesar de a desigualdade e a exclusão estarem indissociavelmente ligadas ao processo de desenvolvimento capitalista, essa mesma sociedade e Estado não podem deixar transparecer que, eventualmente, têm até alguma possibilidade de tirar partido delas. (STOER; CORTESÃO, 1999, p. 13-14)

E assim, podemos inferir que ações como as políticas afirmativas adotadas pelo Estado brasileiro nas últimas décadas, visam à estabilidade da sociedade e do próprio governo, uma vez que "a função primordial do Estado é a manutenção dele mesmo" (SCHURSTER, 2015) ${ }^{9}$, ainda que para isso seja necessário promover mudanças na organização dessa mesma sociedade, o que torna a Escola peça chave em tal processo.

Desse modo, uma vez que outras instituições (família, igreja, militar) vem perdendo espaço dentro da sociedade e sendo a Escola "uma das poucas instituições que, $[\ldots]$ reúne e socializa grandes grupos etários $[\ldots]$ será nela que depositam algumas expectativas de que, por exemplo, se possa manter e reproduzir a cultural nacional” (STOER; CORTESÃO, 1999, p. 20). Entretanto, como falar em "cultura nacional” numa época onde multiculturalidade virou palavra de ordem? Onde as identidades são "fluídas" e a heterogeneidade avança juntamente com o processo de globalização? 
Quando nos reportamos para um dispositivo legal, ou seja, a Lei 10.639/03, que de forma vertical e hierarquizada vem impor/propor uma transformação significativa (mesmo que necessária) no modus operandi de pessoas inseridas num contexto social onde a questão racial é tão complexa quanto no Brasil, nos inquirimos quando e si essa lei irá levar a uma práxis efetiva.

Afinal, a incumbência de cumprir a lei (para não falarmos em 'missão') é dada a Escola, instituição que ao longo de sua existência "passou por mutações que a fizeram caminhar 'de um modelo de certezas para um modelo de promessas e, finalmente para um terceiro, marcado por incertezas"” (KOFF, 2012, p. 173) sem contudo, ofereceremse os aportes necessários para tanto.

E assim, a urgência em reparar 'injustiças' históricas, bem como atender as demandas da sociedade, faz com que as medidas tomadas sejam de difícil implantação, ficando muitas vezes apenas na esfera política ou demonstrando um efeito "cosmético" e lenvando-nos a crer, como colocado por Torres e Ferreira (2014, p. 92), que "[...] a inserção de 'novas' questões envolvendo a História da África e cultura afro-brasileira e africana no país, se ancora em tradições estabilizadas que, em grande parte, foram produzidas na lógica que desejamos combater".

Não se trata, porém, de ignorar os avanços proporcionados pela implementação desta Lei, a qual,

[...] reúne elementos sugestivos de mudanças importantes no ensino da disciplina escolar História, em virtude de ela apresentar tradições curriculares consolidadas e que trazem como marca importante o protagonismo do homem branco em detrimento dos processos vivenciados pelos africanos em nossa sociedade. (TORRES; FERREIRA, 2014, p. 89).

Nem desprezar a notoriedade que esse instrumento legal ganhou junto aos meios de comunicação, nos centros acadêmicos e nas escolas no geral, que foram levados a discutir temas relacionados ao racismo e a discriminação, os quais 
A LEI 10.639/03 E AS RELAÇÕES ÉTNICO-RACIAIS NO AMBIENTE ESCOLAR: MUDANÇAS E PERMANÊNCIAS

representavam tabus dentro da sociedade brasileira, principalmente devido a autoimagem de mestiçagem fomentada, desde a década de 1930 e ao já citado mito da democracia racial ${ }^{10}$, que ocupou o lugar da política de embraquecimento no discurso oficial, mostrando assim o desafio estabelecido na escola, como espaço privilegiado para estudar essa pluralidade cultural e as diversidades de idéias.

Não podemos, entretanto, fugir ao debate sobre a implantação de uma lei com tantas implicações para a sociedade, aceitando-a sem fazer maiores questionamentos acerca dos interesses envolvidos em sua elaboração e a quem a mesma beneficia, uma vez que sua redação, embora controversa em muitos pontos, como já dito antes, é bem clara ao indicar qual "minoria" deve ser valorizada.

Fica claro que é preciso combater o preconceito racial, assim como todo tipo de atitude discriminatória, principalmente no âmbito educacional, mas, e aí nos remetemos a Hanna Arendt novamente, uma decisão política, mesmo que traduza os anseios de uma parte da sociedade, pode garantir a efetivação de mudanças reais nas relações sociais? Ou ficamos apenas no campo do discurso e da retórica?

\section{Em busca de outros princípios pedagógicos}

Os questionamentos acima levantados, bem como a convivência diária com os demais professores e com os alunos, do turno da noite, da Escola Pe. Nicolau Pimentel, localizada no munícipio de Limoeiro, agrestre pernambucano, onde lecionamos e tivemos a oportunidade de presenciar vários momentos em que questões relacionadas à diferença e a diversidade foram motivos de conflitos, fizeram com que déssemos início a presente pesquisa, com a finalidade de analisarmos os efeitos da Lei 10.639/03 na forma como os alunos constroem suas relações com a diversidade e a diferença no ambiente escolar. 
Para nortear nossa pesquisa escolhemos a Lei 10.639/03 como categoria central, em virtude de acreditarmos que ao trazer o Ensino da História e da Cultura Afro-Brasileira e Africana para o currículo da Educação Básica do país, esta Lei abriu caminho não só para o debate acerca das questões relacionadas ao racismo e a discrimininação dos afro-brasileiros, como também deu maior visibilidade para a presença da diferença na Escola.

Outra categoria de análise que elegemos foi a alteridade, ou seja, a capacidade de entender o que é o Outro, aceitando-o como ele é, e não como nós gostaríamos que fosse, conceito que consideramos essencial ao lidarmos com a diferença e a diversidade na sala de aula.

Como nosso objeto de pesquisa eram os alunos da Educação Básica, mas precisamente do Ensino Normal Médio ${ }^{11}$, optamos por utilizar como aborgagem metodologica a pesquisa-ação, por esta “desenvolver-se através de um processo onde os agentes sociais <implicados> interagem tanto no conhecimento como na acção podendo < construir conhecimentos que não seriam possíveis numa relação de exterioridade face à situação explicada >”. (STOER; CORTESÃO, 1999, p. 45).

Com isso em mente, formamos um grupo focal composto pelos/as alunos/as do $4^{\mathrm{a}}$ ano A do Ensino Normal Médio, da já mencionada escola, sendo a turma e, consequentemente o nosso grupo focal, formado por 12 estudantes, três rapazes e nove moças, com idades que variam entre 16 e 21 anos, todos egressos de escolas públicas.

A escolha por esta turma deu-se por indicação dos próprios docentes da escola, que ao ouvirem a natureza da pesquisa que pretendiamos realizar, foram unissonos em apontar a turma do $4^{\mathrm{a}} \mathrm{ENM}$ - A, por serem, segundo eles (professores) alunos/as cuja formação fora feita toda no Ensino Normal Médio e, portanto, eram o exemplo do modelo de professores que o curso estava preparando. 
Até o momento de produção deste artigo, o nosso grupo focal já realizou quatro encontros, sempre tendo como questão disparadora a Lei 10.639/03 e a presença da diferença e da diversidade na sala de aula. Desde o primeiro encontro buscamos, dentro da proposta da pesquisa-ação, estimular os/as alunos/as a externarem suas opiniões acerca do tema, levamos vídeos e textos, procurando observar e perceber suas reações.

O primeiro fato que nos chamou a atenção foi a disparidade entre o quantitativo de homens e mulheres na sala de aula, fenômeno que atribuimos a uma consequência do processo de "feminização do magistério" que, segundo (ROSA, 2011) sofreu uma intensificação a partir do ano de 1908 que

[...] estaria vinculada ao aumento do número de vagas nas escolas e ao processo de urbanização e industrialização que ampliou as oportunidades de trabalho para os homens. Estes foram em busca de empregos mais bem remunerados. (ROSA, 2011, p. 7).

Ficou latente, desde o primeiro encontro que o passo primordial para podermos entender como os/as alunos/as se relacionavam com a diferença (alteridade) na sala de aula, era entender a relação desdes com suas próprias identidades, todavia, como tratase de uma pesquisa voltada para produção de uma dissertação, onde os prazos são curtos e diante da dificuldade que notamos em alguns alunos/as em expressarem-se verbalmente, embora não seja o usual, decidimos elaborar um questionário semiestruturado para levantar algumas informações pertinentes, sem deixar de lado o debate e o diálogo.

Nesse processo, duas perguntas produziram um grande impacto sobre o grupo, a primeira referente aos motivos que os/as levaram a cursar o Ensino Normal Médio, onde apenas uma estudante alegou ter escolhido o curso porque "sempre quiz ser professora" Isaura (18 anos), enquanto os demais alegaram terem iniciado o Normal 
Médio para não serem transferidos para uma Escola Integral (também conhecida como Escola de Referência) ${ }^{12}$.

Foi o caso, por exemplo, dos alunos José13 (19 anos): _ "Não queria ficar na escola de referência, a única opção foi vim fazer o curso normal médio" e Sandro (21 anos): "Por não querer passar o dia todo em escola de referência”.

As alegações dos/as alunos/as nos mostraram uma resistência com relação ao modelo de escola de tempo integral adotado pelo Estado, principalmente em relação ao período de permanência na escola, resistência esssa que tinha como justificativa, na maioria dos casos o fato de que eles/as ajudavam com as tarefas do lar, sendo uma das alunas, inclusive, já casada, o que inviabilizava a permanência em período integral na escola.

Constatamos, também, uma indignação por parte dos mesmos quando referiam-se ao fato que seu direito de escolha tinha sido desrespeitado, situação em que fica clara a já mencionada "dicotomia" existente dentro do próprio sistema educacional público, onde é feita uma diferenciação entre as escolas, sendo umas (como o próprio nome aponta) consideradas de "referência", para as quais são destinados maiores recursos e outras, as regulares, exibidas como "última alternativa".

A outra questão levantada foi com relação a proporção entre "negros", "brancos" e "pardos" nas salas de aula da escola e, em especial, no Ensino Normal Médio. De plano todos concordaram que existiam mais alunos brancos e pardos do que negros, tendo a maioria dos alunos do grupo se declarado "parda", sob a alegação de que era a cor que constava em seus registros de nascimento.

Apenas um aluno declarou-se negro, embora aos olhos de um observador mais atento não haja muita diferença entre ele e alguns dos que se declararam pardos, assim como não há uma diferença significativa (nos referindo exclusivamente ao fenótipo) entre alguns declarados pardos e os que se afirmaram brancos, mostrando uma sintonia 
com os argumentos defendidos tanto por (FRY, 2005) quanto por (MUNANGA, 2014), quando ambos fazem referência à dificuldade de se definir quem é negro num país marcado pela miscigenação, como o Brasil, onde o ser negro e o ser branco são mais uma questão de escolha política e social do que uma determinação biológica.

Essa contradição entre as declarações dos alunos, ilustra bem o que dissemos acima, pois os mesmos alunos que se declararam "pardos" (8/12) também disseram que existiam mais alunos "brancos" na turma, justificando tal afirmação sobretudo através da “observação", como fizeram (JOSÉ, 19) que questioando sobre como chegou a conclusão que existiam mais pessoas "brancas" que "negras" na sala, respondeu que chegou a conclusão pela "observação, durante os 4 anos de convivência".

Enquanto a aluna (EVA, 16), ao ser inquirida sobre a mesma questão, alegou que: _ "Por que a maioria das pessoas da sala são brancas e percebe-se através da observação".

Em poucos momentos, entretanto, a palavra "negro" foi empregada pelos alunos, sendo utilizadas expressões como "pardo/a", "moreno/a", como fez a aluna (MÁRCIA, 18 anos), ao narrar um episódio ocorrido durante o estágio supervisionado numa turma de ensino infantil, no qual precisou intervir, "porque uma menininha estava chorando, porque a outra amiguinha disse que se ela brincasse com o coleguinha que era moreno, não ia querer mais brincar com ela e que ela ia ficar morena também. [grifo nosso].

É interessante observar que mesmo tendo uma atitude aversa ao preconceito mostrado pela "menininha", Márcia usa a palavra "moreno" ao invés de "negro" para caracterizar a outra criança, mesmo que ao falar aponte para sua própria pele (ela declarou-se branca) e diga que a "cor não define quem aprende ou não", nos remetendo ao "etnocídio discursivo" da palavra negro, conforme afirma Kabenguele Munanga, no seu livro Rediscutindo a mestiçagem no Brasil.

A constatação dessa barreira com relação ao uso da palavra "negro" por parte dos/as alunos/as, aponta para existencia de um imaginário socialmente construído e 
situações veladas que são reproduzidas, tornando fulcral o que se conheça os princípios que permeiam o cotidiano escolar, com perspectiva da provisioriedade do mesmo, mostrando a necessidade de repensarmos conceitos como democracia, igualdade e racismo, possibilitando que os/as estudantes conheçam outras visões de mundo.

$\mathrm{E}$ assim, ao tomarmos a escola como "[...] fundamental no processo de construção identitária dos estudantes, na medida em que os processos de identidade e diferença se traduzem em operações de inclusão e de exclusão, em relações de pertencimento ou não pertencimento" (SANTIAGO et al., 2013, p. 34), somos levados a crer que é essencial, nesse contexto de (re)descoberta/busca identitária que a escola e o/a professor/a possam ser capazes de promover práticas e discussões que levem a uma ressignificação de (pre)conceitos e esteriotípicos enraizados numa tradição escolar onde a diferença era vista como "algo a ser consertado".

\section{Considerações Finais}

Iniciamos esta pesquisa sob a crença que a Lei 10.639/03 possui uma dimensão que ultrapassou sua proposta inicial, ou seja, a inserção da História e da cultura afrobrasileira na educação básica, tratando-se de uma tentativa de reforma educacional ambiciosa, à medida que delega à Escola a tarefa, não só de tentar corrigir as "injustiças históricas" com relação aos afro-brasileiros, mas também de buscar a promoção de relações "étnico-raciais" positivas, mostrando, assim, que ainda não deixamos de lado a tradição de querer resolver as demandas sociais através de decretos, incapazes por si só, mudar as práticas vigentes.

Isso porque, tais mudanças exigem que haja uma ressignificação de conceitos por parte dos agentes que irão ser responsáveis por transformar a lei em prática, e este não é um processo simples, pois envolve a reflexão e a substituição, de "verdades", 
"valores", paradigmas e pressupostos que foram construídos/formulados ao longo da vida, levando assim, ao abandono da área de conforto em prol do desconhecido, razão pela qual, nem todos estão dispostos ou preparados a assumir essa nova postura.

Substituir (ressignificar) as práticas pedagogias e educacionais tradicionalmente instituídas, onde a diversidade é lida como "[...] algo que é necessário corrigir, com um olhar que a reconhece sem a querer conhecer" pela "adoção de um olhar inter/multicultural não só como filosofia educativa, mas também como projeto a realizar" (STOER; CORTESÃO, 1999, p. 46), torna-se ainda mais difícil quando a proposta para fazer essa ressignificação vem de fora, ou seja, quando o desejo ou a necessidade de refletir sobre os conceitos pré-estabelecidos não partem de uma motivação do indivíduo.

Tem-se, assim, o que (STOER; CORTESÃO, 1999, p. 21) vão chamar de “professor daltônico cultural”, que é aquele "que não será sensível à heterogeneidade, ao arco-íris de culturas que tem nas mãos quando trabalha com seus alunos na escola" e, desse modo, voltamos à questão inicial, de que a lei, por si só, não basta para promover mudanças efetivas nas relações entre os idivíduos, neste caso, os alunos em sala de aula.

Sempre haverá quem diga que 13 anos é tempo insuficiente para ocorrerem transformações significativas tanto na sociedade quanto nas representações e práticas individuais com relação à aceitação da diversidade, não discordamos, mas perguntamos: as ações e políticas afirmativas tomadas até então tem realmente ajudado a promover tais mudanças?

Não podemos afirmar. O que acreditamos é que as relações de igualdade e solidariedade entre grupos socioculturais diferentes precisam ser construída, assim como foram as desigualdades e exclusões e esse é um processo que demanda grandes mudan- 
ças não só na estrutura política, social e econômica do país, como também e, principalmente, na forma como os indivíduos enxergam a si e aos outros, sendo estes últimos, conforme discorremos acima, fatores sobre os quais acreditamos que as leis exerçam pouca ou nenhuma influência significativa.

Mesmo as ações afirmativas do Estado, possuem uma natureza ambígua neste processo, pois ao passo que visam diminuir as assimetrias sociais, reforçam os discursos racialistas, do qual são dependentes, razão pela qual qualquer previsão que façamos sobre o caminho das relações "étnico-raciais” no Brasil, não passará de mera especulação.

Por último, é importante ressaltarmos que esse é um tema que gera muito mais questionamentos que respostas, afinal, seremos capazes de superar o ressentimento causado por décadas de uma violenta segregação humana em prol do ideal de uma sociedade mais igual? Algum povo será?

Paira a dúvida, então.

\section{Notas:}

${ }^{1} \mathrm{O}$ atual Ensino Médio já recebeu o nome de Segundo Grau, Científico e Ensino Secundário.

${ }^{2}$ Em tal contexto, Colégio Pedro II talvez tenha sido o símbolo maior dessa "segregação", pois "[...] foi criado com o propósito de formar as elites nacionais, os altos quadros políticos, administrativos e intelectuais do país” (BRASIL, 2013, p. 07).

${ }^{3}$ No Brasil, as pressões exercidas pelos movimentos sociais populares nos grandes centros urbanos e industriais do país, como São Paulo, entre o final dos anos 1940 e os anos 1960, levaram à expansão das oportunidades educacionais e à integração formal do ensino primário ao primeiro ciclo do ensino médio, o antigo ginásio. Ironicamente, foi o governo militar, por meio da Lei $\mathrm{n}^{\circ}$ 5.692/71, que introduziu formalmente a mudança, fixando a obrigatoriedade do ensino comum de oito anos. In: (BRASIL, 2013, p. 19).

${ }^{4}$ Citamos como exemplos, o reconhecimento do direito a terra de comunidades quilombolas e a abertura do debate acerca da visão do Brasil como uma país multirracial e multicultural, desafiando o ideal da mestiçagem.

${ }^{5}$ A Lei 10.639/03 e posteriomente a Lei 11.645/08 vêm alterar a Lei de Diretrizes e Bases da Educação, de 1996, acrescentando os arts. 26-A, 79-A e 79-B, trazendo, juntamente com as Diretrizes

Cadernos de Pós-graduação, São Paulo, v. 17, n. 2, p. 121-140, jan./jun. 2018. 
Curriculares Nacionais para a Educação das Relações Étnico-Raciais e para o Ensino de História e Cultura Afro-Brasileira e Africana, orientações mais explícitas para que as heranças culturais dos povos que contribuíram para a formação do país sejam tratadas de forma igualitária nas instituições escolares, ao tornar obrigatória a inclusão do Ensino da História e da Cultura Afro-brasileira e Africana e dos povos indígenas, em todos os níveis da educação do país.

${ }^{6}$ Para saber mais sobre o tema, mudança, tradição e inovação ver: HOBSBAWN, Eric; RANGER, Terence. (org) A invenção das tradições. 4e. São Paulo: Paz e Terra, 2006.

${ }^{7}$ O conceito de significante vazio é trabalhado por Ernest Laclau, no livro A razão populista.

${ }^{8}$ Aliás, o fato da Lei 10.639/03 não mencionar os povos indígenas, que assim como os afrobrasileiros, são considerados sujeitos a quem foi negada uma reprsentação igualitária na História do Brasil, bem como a sua posterior inclusão, através da Lei 11.645/08, mostra essa cadeia de equivalências e como o centro de poder pode ser deslocado se um grupo conseguir juntar as condições necessárias para impor suas reividicações ante o Estado e a sociedade.

${ }^{9}$ Informação verbal. Aula ministrada em 17/03/2015. 1 ${ }^{\text {a }}$ Turma de Mestrado em Educação da Universidade de Pernambuco, Campus Mata Norte.

${ }^{10}$ Ao menos até as décadas de 1960-70, quando tem lugar as pesquisas da UNESCO e o fortalecimento dos movimentos negros. Para saber mais ver: FRY, Peter. A persistência da raça: ensaios antropológicos sobre o Brasil e a África austral. Rio de Janeiro: Civilização Brasileira, 2005.

11 Modalidade de ensino que, ao nosso vê, produz uma categoria de estudantes que classificamos como "hibrida", dentro do universo escolar, pois ao mesmo tempo em que estão cursando as disciplinas obrigatórias para conclusão do Ensino Médio, também estão sendo preparados para se tornarem futuros professores.

${ }^{12}$ Modalidade na qual os alunos permanecem os dois turnos, manhã e tarde, na escola.

${ }^{13}$ Os nomes utilizados neste artigo são todos ficticios, afim de preservar a identidade dos participantes da pesquisa.

\section{REFERÊNCIAS}

RANTES, Adlene Silva. Processos de racialização nas escolas primárias pernambucanas (19111945). 2014. 255 f. Tese (Doutorado) - Universidade Federal da Paraíba (UFPB), João Pessoa, 2014.

BRASIL. Secretaria de Educação Básica. Formação de professores do ensino médio, etapa I caderno $I$ : ensino médio e formação humana integral / Ministério da 
Educação,Secretaria de Educação Básica; [autores : Carmen Sylvia Vidigal Moraes... et al.]. - Curitiba: UFPR/Setor de Educação, 2013. 51p. : il. algumas color., retrs.

FRY, Peter. A persistência da raça: ensaios antropológicos sobre o Brasil e a África austral. Rio de Janeiro: Civilização Brasileira, 2005.

KOFF, Adélia Maria Nehme Simão e. Reinventado a escola: relato de uma experiência de trabalho com projetos. In: CANDAU, Vera Maria. (Org.) Didática crítica intercultural: aproximações. Petrópolis, RJ: Vozes, 2012.

LACLAU, Ernest. Emancipação e diferença. Rio de Janeiro: Ed.UERJ, 2011.

MUNANGA. A difícil tarefa de definir quem é negro no Brasil. Entrevista. Revista Estudos Avançados, 18 (50), 2014. p. 51-56. Disponível em: $<$ http://www.scielo.br/scielo.php?script $=$ sci serial\&pid $=0103$ 4014\&lng=pt\&nrm=iso $>$. Acesso em: 03 out. 2015.

ROSA, Renata Vidica Marques da. Feminização do Magistério: Representações e espaço docente. Revista Pandora Brasil. Edição especial n 4 - Cultura e materialidade escolar, 2011. Disponível em: http://revistapandorabrasil.com/revista_pandora/materialidade/renata.pdf. Acesso em: 03 out. 2015.

SANTIAGO, Mylene Cristina et al. Educação intercultural: desafios e possibilidades. Petrópolis, RJ: Vozes, 2013.

SCHURSTER, Karl. Estado e Políticas Educacionais no Brasil. Aula ministrada em 17/03/2015, para a $1^{\text {a }}$ Turma do Mestrado em Educação da Universidade de Pernambuco, Campus Mata Norte.

STOER, Stephen; CORTESÃO, Luiza. Levantando a pedra:. da pedagogia inter/multicultural às políticas educativas numa época de transnacionalização. Porto: Edições Afrontamento, 1999.

TORRES, Marcele Xavier; FERREIRA, Marcia Serra. Currículo de História: Reflexões sobre a problemática da mudança a partir da Lei 10.639/03. In: MONTEIRO, Ana 
Maria [et al]. Pesquisa em ensino de história: entre desafios epistemológicos e apostas políticas. Rio de Janeiro: Mauad X: Faperj, 2014.

recebido em 29 jun. 2018 / aprovado em 23 out. 2018

\section{Para referenciar este texto:}

SANTANA, N. M. A. A lei 10.639/03 e as relações étnico-raciais no ambiente escolar: mudanças e permanências. Cadernos de Pós-graduação, São Paulo, v. 17, n.2, p. 121-140, jul./dez. 2018. Disponível em: <https://doi.org/10.5585/cpg.v17n2.8865>. 
Artigo Article 


\title{
FORMAÇÃO DE EDUCADORES E A EDUCAÇÃO INCLUSIVA: DA SENSIBILIDADE ÉTICO-POLÍTICA À CONDIÇÃO HUMANA
}

\section{EDUCATION TRAINING AND INCLUSIVE EDUCATION:}

\section{FROM ETHICAL-POLITICAL SENSITIVITY TO HUMAN CONDITION}

\author{
Marisa Soares \\ Doutora em educação pela Universidade Nove de Julho. Professora Visitante da \\ Universidade Federal do ABC - Santo André - SP - Brasil \\ soares.m@ufabc.edu.br
}

\begin{abstract}
Resumo: Esta pesquisa focalizou a educação especial no ensino fundamental, objetivou investigar a convivência cotidiana da inclusão do aluno especial com seus professores, colegas de classe e demais participantes da escola pesquisada. As metodologias utilizadas foram o Estudo de Caso em uma escola municipal e a Revisão Bibliográfica. Descreve-se, a partir dos relatórios desenvolvidos no cotidiano escolar do ensino fundamental de nove anos, uma análise bibliográfica, baseada principalmente pela perspectiva de um processo de ensino e aprendizagem inclusivo da Educação Especial. Consideramos que no atual contexto, o ideal a ser resgatado é a nossa diversidade e nossa integridade humana, pois a condição da Educação relaciona-se reciprocamente com a condição humana. $O$ papel da Educação situa-se na possibilidade da inclusão social, da diminuição das desigualdades e da discriminação para com as pessoas que não tiveram acesso ao ensino, ao trabalho, aos seus direitos e aos meios culturais. Palavras-chave: Formação docente. Educação Inclusiva. Educação Especial.
\end{abstract}

\begin{abstract}
This research focused on special education in elementary school, aimed at investigating the daily coexistence of the inclusion of the special student with his teachers, classmates and other participants of the school. The methodologies used were the Case Study at a municipal school and the Bibliographic Review. It is described, based on the reports developed in the school daily life of nine years of elementary school, a bibliographical analysis, based mainly on the perspective of an inclusive teaching and learning process of Special Education. We believe that in the present context, the ideal to be redeemed is our diversity and
\end{abstract}

Cadernos de Pós-graduação, São Paulo, v. 17, n. 2, p. 143-166, jul./dez. 2018. 
our human integrity, since the condition of Education relates to the human condition. The role of education lies in the possibility of social inclusion, the reduction of inequalities and discrimination towards people who have not had access to education, work, their rights and cultural means.

Keywords: Teacher Education. Inclusive Education. Special Education.

\section{Introdução}

ste artigo apresenta a partir dos relatórios de uma pesquisa realizada no
cotidiano escolar do ensino fundamental de nove anos, uma análise bibliográfica, baseada principalmente, pela perspectiva de um processo de ensino e aprendizagem inclusiva na Educação Especial. Inicialmente, esclarecemos a perspectiva do termo "escola inclusiva" na Educação Especial. De acordo com Almeida (2002), a Educação Especial é uma modalidade de ensino que visa promover o desenvolvimento das potencialidades de pessoas portadoras de necessidades especiais, condutas típicas ou altas habilidades, e que abrange os diferentes níveis e graus do sistema de ensino. Esta modalidade educacional está fundamentada em referenciais teóricos e práticos compatíveis com as necessidades especificas de seu alunado. Dentro desta concepção, compreendamos que uma escola inclusiva é aquela em cujo processo educativo desenvolve-se como um processo social, pelo qual todas as crianças portadoras de necessidades especiais e de distúrbios de aprendizagem têm o direito à escolarização o mais adequado possível do normal. "Uma escola inclusiva deve ser uma escola líder em relação às demais. Ela se apresenta como a vanguarda do processo educacional" (ALMEIDA, 2002).

Atualmente, o Sistema Nacional de Educação brasileiro tem implantado políticas públicas que inovam por estabelecer que o ensino tem a necessidade de atender a diversidade de nossa sociedade, priorizando as necessidades de todos os alunos, ao se 
considerar as suas diferenças, com vista a elaborar espaços educacionais que valorizam as relações humanas que se estabelecem no cotidiano escolar.

\section{Políticas públicas nacionais e internacionais para a Educação Especial}

Conforme a Organização das Nações Unidas para a Educação, a Ciência e a Cultura - UNESCO (2005) a inclusão é "uma abordagem dinâmica de responder positivamente à diversidade, quando se observam as diferenças individuais não como problemas, mas como oportunidades para enriquecer a aprendizagem". A Educação Inclusiva atende as reivindicações por reconhecimento de uma população com necessidades especiais que se integrem à sociedade como na concepção de Fraser (2007), no "modelo de status", pois procuram tornar o sujeito que se encontra numa situação de isolamento ou subordinação, para se tornar um parceiro integral na vida social, capaz de interagir com os outros em parcerias construtivas. Desta maneira, reconhecer um aluno com necessidades especiais como ser integrante de nosso sistema de ensino e de nossa vida cotidiana é uma forma de desmistificar padrões de valoração cultural que impedem a paridade de participação e substituí-los por padrões que a promovam. Este avanço, ultrapassa os limites vivenciados na educação brasileira nos anos de 1950, conforme BRASIL (2009a), a partir dos anos 50 até o início dos anos 2000, a educação brasileira passou pela redemocratização do Brasil e pela Constituição Federal de 1988, nesse período se praticou um ensino no qual a "abordagem dos estudantes era realizada sob o marco de uma psicologia "medicalizada", a qual deveria solucionar os "desvios" e/ou "déficits" ligados ao comportamento/disciplina e/ou a capacidade de aprender e/ou atentar".

Também observamos a amplitude da Educação Especial em contextos internacionais, porque a estrutura de ação em educação especial foi adotada pela 
POLÍTICA À CONDIÇ̃̃O HUMANA

conferência Mundial em Educação Especial organizada pelo governo da Espanha em cooperação com a UNESCO, realizada em Salamanca entre 7 e 10 de junho de 1994. Desta conferência originou-se a Declaração de Salamanca sobre os Princípios, Políticas e Práticas em Educação de Necessidades Especiais (UNESCO, 1988). Essa Declaração culminou-se no documento das Nações Unidas "Regras Padrões sobre Equalização de Oportunidades para Pessoas com Deficiências", o qual demanda que os Estados assegurem que a educação de pessoas com deficiências seja parte integrante do sistema educacional. Destacamos alguns aspectos dessa Declaração:

Aqueles com necessidades educacionais especiais devem ter acesso à escola regular, que deveria acomodá-los dentro de uma Pedagogia centrada na criança, capaz de satisfazer a tais necessidades, escolas regulares que possuam tal orientação inclusiva constituem os meios mais eficazes de combater atitudes discriminatórias criando-se comunidades acolhedoras, construindo uma sociedade inclusiva e alcançando educação para todos; além disso, tais escolas provêm uma educação efetiva à maioria das crianças e aprimoram a eficiência e, em última instância, o custo da eficácia de todo o sistema educacional (UNESCO, 1988).

No Brasil, o Decreto Legislativo no 198, de 13 de junho de 2001 foi promulgado a partir da Convenção Interamericana para a Eliminação de Todas as Formas de Discriminação contra as Pessoas Portadoras de Deficiência. Os Estados integrantes desta Convenção de Guatemala, reafirmaram que as pessoas portadoras de deficiência têm os mesmos direitos humanos e liberdades fundamentais que outras pessoas e que estes direitos, inclusive o direito de não ser submetidas a discriminação com base na deficiência, emanam da dignidade e da igualdade que são inerentes a todo ser humano (BRASIL, 2016b).

O Fórum Mundial de Educação iniciou-se em 1990, na Conferência de Jomtien, sendo reiterada em 2000, no Fórum Mundial de Educação realizado em Dakar. Em maio de 2014, em Incheon, na Coreia do Sul, aconteceu o Fórum Mundial de Educação com o objetivo de acordar a nova agenda da educação, que irá vigorar entre 2015 e 
2030, com os novos objetivos que compõem o compromisso de Educação para Todos, pelo qual é afirmada a importância da educação como principal impulsionadora do desenvolvimento e reforça o compromisso de "garantir educação inclusiva e equitativa e promover oportunidades de educação e aprendizagem ao longo da vida para todos" (UNICEF, 2015).

De acordo com a UNESCO (2015), no ano de 2014, durante o Encontro Global de Educação para Todos, em Omã, foi adotado o Acordo de Muscat, que apresenta a visão sobre a agenda da educação para os próximos anos. Para dar continuidade aos objetivos de Desenvolvimento do Milénio (ODM) está sendo posto em prática um novo quadro de desenvolvimento global, isto é, a "Agenda de Desenvolvimento Pós-2015” que culminará com a elaboração de um novo conjunto de metas e objetivos - os Objetivos de Desenvolvimento Sustentável (ODS). Dentro desse relatório em nossa pesquisa somente focalizamos o Objetivo proposto 4: Garantir uma educação de qualidade inclusiva e Equitativa e promover oportunidades de aprendizagem ao longo da vida para todos. Assim como o item: 4.4 que delibera que até 2030, devem ser eliminadas as disparidades de gênero na educação e garantir a igualdade de acesso a todos os níveis de educação e formação profissional para os mais vulneráveis, incluindo as pessoas portadoras de deficiência, povos indígenas e crianças em situação de vulnerabilidade.

\section{A formação de educadores e as políticas públicas da educação inclusiva}

Quando nos referimos à formação de educadores temos como um parâmetro para a qualificação dessa formação o artigo nº 62 da LDB, porque a partir da vigência da LDB de 1996 se estabeleceu que, a formação de docentes para atuar na educação básica deveria ser realizada em nível superior, por meio de curso de licenciatura e de 
graduação plena, em universidades, faculdades e institutos superiores de educação, admitida, como formação mínima para o exercício do magistério na educação infantil e nas quatro primeiras séries do ensino fundamental, a oferecida em nível médio, na modalidade Normal (BRASIL, 2016c). Destacamos em seguida a vigência do Decreto que regulamentou a Lei no 10.436 , de 24 de abril de 2002, e o art. 18 da Lei no 10.098 , de 19 de dezembro de 2000, pelos quais:

Art. 3o A Libras deve ser inserida como disciplina curricular obrigatória nos cursos de formação de professores para o exercício do magistério, em nível médio e superior, e nos cursos de Fonoaudiologia, de instituições de ensino, públicas e privadas, do sistema federal de ensino e dos sistemas de ensino dos Estados, do Distrito Federal e dos Municípios.

$\int 10$ Todos os cursos de licenciatura, nas diferentes áreas do conhecimento, o curso normal de nível médio, o curso normal superior, o curso de Pedagogia e o curso de Educação Especial são considerados cursos de formação de professores e profissionais da educação para o exercício do magistério.

\2o A Libras constituir-se-á em disciplina curricular optativa nos demais cursos de educação superior e na educação profissional, a partir de um ano da publicação deste Decreto (BRASIL, 2016c).

Para que houvesse a vigência dessa Lei ocorreu um processo iniciado no ano de 2006 para que fosse alterado na Lei $\mathrm{n}^{\circ}$ 9.394, de 20 de dezembro de 1996, que estabelece as Diretrizes e Bases da Educação Nacional, para incluir no currículo oficial da Rede de Ensino a obrigatoriedade da oferta da Língua Brasileira de Sinais - Libras, em todas as etapas e modalidades da educação básica. A partir dessa primeira proposta a Comissão de Constituição, Justiça e de Cidadania aprovou no ano de 2011 a proposta final que obrigava as escolas públicas e privadas a oferecerem a seus alunos com necessidades especiais as linguagens específicas que lhes permitam uma perfeita comunicação, como a Língua Brasileira de Sinais (Libras) e o Sistema Braile.

Primeiramente, essa proposta, foi levada para a aprovação do Senado, onde se estabeleceu que os sistemas de ensino deverão assegurar aos alunos com necessidades 
especiais métodos pedagógicos de comunicação, entre eles: Língua Brasileira de Sinais (Libras), tradução e interpretação de Libras, ensino de Língua Portuguesa para surdos, sistema Braille; recursos áudios e digitais, orientação e mobilidade; tecnologias assistivas e ajudas técnicas; interpretação da Libras digital, tadoma e outras alternativas de comunicação (CÂMARA DOS DEPUTADOS, 2016).

Existe uma perspectiva a ser avaliada sobre a questão do tempo para a implantação de uma Lei, desde sua tramitação burocrática e os investimentos de cada município para a implementação das suas escolas até o poder de atuação do Estado para os investimentos de recursos e de avaliação dos cursos para a formação e capacitação de educadores.

No Brasil, conforme o censo de 2010 constam 45.623.910 que apresentam alguma deficiência. Os índices de pessoas com deficiências visuais são de 528,624 pessoas que não conseguem enxergar de modo algum, 6.056.684 que se apresentam com grande dificuldade de visão e 29.206.180 que apresentam alguma dificuldade de visão, sendo que esta camada da população aprende a conviver com as Tecnologias da Informação e da Comunicação, as quais se apresentam como geradoras de fortes mudanças na Educação, uma vez que proporcionam novas formas de difusão do conhecimento.

Fator este, que desencadeia novas relações e práticas educativas entre professores e alunos. Conforme Medeiros (2010): “A produção de livros em Braille é bastante morosa, cara e insuficiente para as necessidades dos leitores." A autora explica que por essa razão, nunca se conseguiu que a produção de livros em Braille acompanhasse o fluxo editorial de livros à tinta, sendo que os serviços produtores tiveram que fazer opções e ainda há gêneros literários que não puderam ser contemplados. Um livro escrito em Braille ocupa muito espaço, por exemplo um 
dicionário de bolso pode ter 17 volumes, além disso, os dicionários mais completos não são transcritos.

Outro aspecto observado é o sistema de avaliação IAR, cujo foi selecionado por conter, em suas tarefas, atividades pertinentes ao currículo da Educação Infantil, possibilitando a obtenção de um quadro de como os alunos se apresentam em relação a tais habilidades, ou seja, aos conceitos adquiridos. Trata-se de uma avaliação constituída por uma série de situações em que o aluno deve emitir respostas escritas ou verbais, aplicadas em grupo ou individualmente. Para esta avaliação, "foi realizado estudo de casos de três crianças cegas, com oito anos de idade, atendidas no Centro de Distúrbios da Audição, Linguagem e Visão (CEDALVI), do Hospital de Reabilitação de Anomalias Craniofaciais (HRAC) da USP, Campus Bauru" (RABELLO et al., 2007, p. 284).

A estrutura do IAR abrange 13 áreas: 1. Esquema corporal (reconhecer, desenhar e pintar as partes do corpo); 2. Lateralidade (noção de direção com pintura dos desenhos); 3. Posição (utilização dos conceitos em cima/em baixo, dentro/fora, ao lado/em frente, atrás); 4. Direção (para cima/ para baixo); 5. Espaço (perto/longe); 6. Tamanho (maior/menor, grande/pequeno, grosso/fino, alto/baixo); 7. Quantidade (mais/menos, cheio/vazio, muitas/nenhuma); 8. Forma (noção de formas geométricas); 9. Discriminação tátil (percepção de detalhes e posição em figuras, letras, sílabas e palavras); 10 . Discriminação auditiva (reconhecimento das figuras que iniciam ou terminam com o mesmo som; seguindo o modelo aplicado); 11. Verbalização de palavras (repetir as palavras mencionadas); 12. Análise/Síntese (modelos de formas geométricas para serem reconhecidos e comparados ao modelo dado no exercício); 13. Coordenação Motora Fina (completar a lápis, de acordo com o modelo). Nesta avaliação somente uma criança havia sido alfabetizada em Braille, a 
qual foi avaliada pelas sílabas e palavras escritas no Sistema Braille (RABELO et al., 2007, p. 284-285).

Esse método demonstra que também requer uma base a alfabetização em Braille, de maneira que não é possível avaliar uma criança sem que, primeiramente, tenha sido alfabetizada pelo sistema Braile. Segundo Cardoso (2010), "o problema foi discutido na convenção anual que a Federação Nacional dos Cegos dos Estados Unidos. No evento, havia painéis com o slogan: Ouvir não alfabetiza?”. Estes painéis foram espalhados para chamar a atenção para um dado preocupante: $90 \%$ das crianças americanas com deficiência visual estão crescendo sem aprender a ler e a escrever, e estão escravas de inovações como serviços telefônicos que leem o jornal e leitura em voz alta de e-mails. Essas tecnologias promovem um tipo passivo de leitura. Necessitase do sistema Braille para que o cérebro do deficiente visual desenvolva e construa seus conhecimentos sobre as letras, a pontuação e a estrutura de textos.

Uma questão importante situa-se no processo de ensino e aprendizagem pelo sistema Braille, pelo qual a criança pode ser alfabetizada, ou seja, aprende a ler e escrever, as regras gramaticais, a compreensão da língua estudada, a qual propicia ao mesmo tempo uma reflexão crítica, um amadurecimento intelectual da criança, a convivência com o professor, a satisfação de apropriar-se do novo conhecimento etc. Numa visão geral, observa-se que tanto a alfabetização em Braille no cotidiano escolar ocorre com muitas deficiências e dificuldades, quanto o acesso às tecnologias não se encontra realizado de forma igualitária na Educação brasileira.

Desta maneira, para que sejam realizadas factuais mudanças no sistema educacional brasileiro no âmbito da inclusão de alunos com necessidades especiais, fazse necessário superar alguns desafios educacionais sócio históricos, por exemplo, o fracasso e a evasão escolar dos alunos, a falta de investimento significativo para a 
qualidade do ensino público, as condições de trabalho dos professores, entre tantos outros.

A educação inclusiva no atual contexto brasileiro depende da articulação da educação como um todo, isto é, desde a educação infantil ao ensino superior, visando implementar projetos sociais e pedagógicos interdisciplinares, como por exemplo, projetos de educação correlata, temas transversais, pluralidade cultural e da saúde das crianças, alimentação saudável, práticas de esporte e de dança, música e poesia, entre outros exemplos que delineiam uma visão de educação inclusiva. Para o investimento da educação especial, destacamos no Decreto n ${ }^{\circ}$ 7.611, de 17 de novembro de 2011, o Art. $3^{\circ}$ dos objetivos do atendimento educacional especializado:

I - Prover condições de acesso, participação e aprendizagem no ensino regular e garantir serviços de apoio especializados de acordo com as necessidades individuais dos estudantes;

II - Garantir a transversalidade das ações da educação especial no ensino regular;

III - fomentar o desenvolvimento de recursos didáticos e pedagógicos que eliminem as barreiras no processo de ensino e aprendizagem; e

IV - Assegurar condições para a continuidade de estudos nos demais níveis, etapas e modalidades de ensino (BRASIL, 2016d).

Este mesmo Decreto $\mathrm{n}^{\circ} 7.611 \mathrm{em}$ seu Art. $9^{\circ}$ regulamenta que para efeito da distribuição dos recursos do FUNDEB, será admitida a dupla matrícula dos estudantes da educação regular da rede pública que recebem atendimento educacional especializado, ou seja, o estudante pode se matricular tanto na educação regular da rede pública, quanto no atendimento educacional especializado. Sendo que o atendimento educacional especializado aos estudantes da rede pública de ensino regular poderá ser oferecido pelos sistemas públicos de ensino ou por instituições comunitárias, 
confessionais ou filantrópicas sem fins lucrativos, com atuação exclusiva na educação especial, conveniadas com o Poder Executivo competente.

O apoio e o financiamento dos recursos para a educação especial englobam várias políticas públicas, pois abrange diversos setores da sociedade. Inicia-se pelo monitoramento do Ministério da Educação que acompanha o acesso à escola por parte dos beneficiários do benefício de prestação continuada, em colaboração com o Ministério da Saúde, o Ministério do Desenvolvimento Social e Combate à Fome e a Secretaria de Direitos Humanos da Presidência da República (BRASIL, 2016d).

No Peru, uma pesquisa ganhadora do III concurso nacional de experiências exitosas em educação inclusiva realizado pela UNESCO, tratou-se da pesquisa de Nuñez (2014), na qual se identificou que a atitude da comunidade é um elemento complementar e de suporte para todo o processo da educação inclusiva, quanto ao sucesso deste, pois os alunos com deficiência devem sentir que o ambiente da escola é inclusivo, para construir a confiança no processo educacional e a aceitação de seu próprio valor. Observamos que se trata de um desafio para o professor ao administrar duas frentes, ou seja, as dificuldades da criança com necessidades especiais e das demais crianças que convivem na mesma sala de aula, assim como da aceitação de suas famílias.

Nesta pesquisa ocorreu uma representativa rejeição por parte dos familiares das crianças sem necessidades especiais, pois não consideravam adequada a inclusão, ocorreram alguns casos de que seus filhos se queixaram de terem sido beliscados. Mediante os acontecimentos a professora organizou reuniões com os familiares e projetos pedagógicos sobre os temas transversais para melhorar o ambiente em sala de aula, progressivamente inseriu atividades e dinâmicas que necessitavam de compartilhamento entre os alunos. Todos esses esforços geraram novas formas e recursos de aprendizagem para os alunos, assim como no aperfeiçoamento das experiências da professora. A pesquisa considerou importante fazer novas adaptações 
curriculares e desenvolver materiais didáticos e técnicas que propiciem um ambiente inclusivo, elaborar instrumentos adequados de avaliação, pelos quais seja aprimorada a aprendizagem e as conquistas alcançadas pelas crianças incluídas.

Acreditamos que seja muito importante no decorrer da graduação dos futuros professores, a realização de análises de artigos científicos e de trabalhos de pesquisa sobre experiências práticas da inclusão de alunos especiais, haja vista que esses relatos de experiências, estudos de caso, revisões bibliográficas, entre outras formas metodológicas de pesquisa, proporcionam uma visão ampla e crítica sobre a inclusão.

\section{Escritos e análises do cotidiano escolar da escola pesquisada}

A escola municipal de ensino fundamental pesquisada situa-se num bairro da região central do município, localizada com proximidade de comércios, agências bancárias, parque municipal, shopping, posto de saúde, centro esportivo, universidades, escolas técnicas entre outros recursos.

A pesquisa de campo realizou-se no período um semestre letivo, quando se acompanhou a rotina de uma sala do quinto ano do ensino fundamental de nove anos. Os alunos que residem no bairro da escola representavam 30\%, sendo a maioria de $70 \%$ residente em diferentes bairros do município, esta característica definiu um perfil heterogêneo do alunado. A idade predominante dos alunos situa-se entre 6 a 10 anos.

A escola conta com 20 funcionários, sendo um oficial da escola, dois inspetores de alunos, cinco auxiliares de limpeza, um bibliotecário, sete professoras, um coordenador pedagógico, a diretora, a vice-diretora e uma professora auxiliar de AEE - Atendimento Educacional Especializado.

No que se refere à inclusão, a escola disponibiliza atendimento especial na sala de Atendimento Educacional Especializado (AEE) no contra turno e atendimento 
domiciliar (quando necessário), por meio de profissional especializado aos alunos com necessidades especiais, principalmente os que apresentam deficiências neurológicas. Como também, oportuniza aos alunos com algum nível de dificuldade ou defasagem no processo de aprendizagem, aulas de Apoio à Aprendizagem (PAA) no contra turno. Em sua totalidade, constatou-se a inclusão de seis alunos com necessidades especiais.

O relatório foi desenvolvido sobre a rotina escolar de uma turma, na qual havia somente um aluno de inclusão, a professora responsável pela classe lecionava para um grupo de 25 alunos e contava com uma professora de AEE específica para o acompanhamento do aluno com necessidades educacionais especiais (NEE), cujo apresentava dependência da professora para suas atividades motoras, dependia de seu apoio para locomoção, higiene e alimentação. A inclusão deste aluno (NEE) se realizou na estratégia de ensino de ação colaborativa, explicada por Marin; Maretti, (2014, p. 2):

Por meio de uma relação dialógica entre dois docentes, um de apoio específico e o regente da turma, busca-se repensar algumas práticas e desenvolver diferenciações pedagógicas necessárias por meio do ensino colaborativo. A tarefa é garantir que cada aluno construa o mesmo conhecimento dos outros estudantes e que consiga desenvolver as atividades dentro de sala de aula.

O município propiciava um transporte especializado para o aluno, com acessibilidade para sua cadeira de rodas, no itinerário entre sua residência e a escola. Nesta escola havia o Programa Saúde na Escola (PSE), instituído por Decreto Presidencial $\mathrm{n}^{\circ}$ 6.286, de 5 de dezembro de 2007, sendo resultado do trabalho integrado entre o Ministério da Saúde e o Ministério da Educação, na perspectiva de ampliar as ações específicas de saúde aos alunos da rede pública de ensino: Ensino Fundamental, Ensino Médio, Rede Federal de Educação Profissional e Tecnológica, Educação de Jovens e Adultos (BRASIL, 2009a).

A prática do Programa Saúde na Escola, abrange o teste antropométrico (peso e altura), a acuidade visual (teste de visão) e a verificação da carteirinha de vacina das 
crianças. Também incorpora a saúde bucal das crianças, por meio do grupo de dentistas que classificam na escola, os alunos com risco de cárie e de outros problemas dentários. Os profissionais orientam os processos de escovação monitorada, assim como se realiza a distribuição de conjuntos de higiene dental: escova, pasta e fio dental. Ressaltase na interação dos dentistas com as crianças, uma ausência de um profissional da saúde especializado ou com capacitação para o atendimento de crianças com necessidades especiais, nestas visitas a escola municipal pesquisada. Possivelmente, seja um padrão do município direcionar os atendimentos especiais para uma de suas duas unidades do programa Brasil Sorridente/Centro de Especialidades Odontológicas (CEO) que também prestam serviços às pessoas com necessidades especiais. Nas duas unidades dos CEOs são realizados, semanalmente, cerca de 140 atendimentos. Os casos mais graves são encaminhados ao Hospital Municipal Universitário (HMU). São considerados pacientes com necessidades especiais aqueles que têm agravos neurológicos, Síndrome de Down, autismo, esquizofrenia, que estão em tratamento oncológico, nefropatas, cardiopatas, gestantes de risco e outros comprometimentos de saúde que exigem atendimento diferenciado. (RIBEIRO, 2015).

Em 2015, foi instituída a Lei Brasileira de Inclusão da Pessoa com Deficiência, a qual em seu contexto geral preconiza acessibilidade e igualdade ao indivíduo portador de qualquer alteração que possa obstruir sua vivência em sociedade. Nesta Lei em seu terceiro capitulo é definido que, por intermédio do SUS, o paciente deve receber um atendimento com atenção integral e a possibilidade de participar de serviços para habilitação e reabilitação. Para tal, é necessário o acolhimento do paciente por uma equipe multidisciplinar capacitada, sendo, portanto, um requisito para a formação da equipe (BRASIL, 2016d).

Tendo em vista a instituição desta Lei, o Conselho Federal de Odontologia reconheceu o Atendimento de Pacientes com Necessidades Especiais como uma 
especialização em 2001, e incluiu em sua resolução de 2015 a integração e a preferência do agendamento e atendimento ao paciente especial (BRASIL, 2016c). Destacamos a importância de se incentivar projetos pedagógicos para o atendimento ao aluno especial, por meio de parcerias entre as escolas, os municípios e os Centros de Especialidades Odontológicas. Observamos que a rotina cotidiana das aulas se realizava normalmente, as demais crianças faziam suas atividades escolares em suas carteiras e o aluno especial ficava na parte lateral da sala em sua cadeira de rodas, havia um colchonete para que a professora de AEE pudesse deitá-lo, caso ficasse incomodado pela permanência contínua em sua cadeira. A aula se iniciava às 13:00 horas e seu término às 18:00, entretanto, havia uma flexibilidade no horário e na permanência em sala de aula comum para o aluno especial. Toda segunda-feira, no horário das 13:00 às 14:00, a sala de AEE estava reservada para atividades pedagógicas específicas para o aluno de NEE. Sua alimentação, sua higienização ou outras atividades também podiam ser realizadas nas demais salas de apoio pedagógico da escola.

Preferencialmente, o AEE se articulava com a proposta pedagógica da escola, embora suas atividades se diferenciassem das realizadas em salas de aula de ensino comum. De uma forma geral, a presença da professora de AEE e do aluno especial não tornavam o ambiente diferente de uma sala de aula sem a presença da educação especial. Entretanto, deve-se relevar um aspecto importante a ser observado, porque a presença do aluno especial, desenvolveu uma característica peculiar no comportamento geral da classe, isto é, os outros alunos da classe se sentiam responsáveis em oferecer um bom ambiente ao colega, havia pouca indisciplina nesta sala de aula.

Resumidamente, o Atendimento Educacional Especializado nesta escola abrange:

1. Apoio ao desenvolvimento do aluno com deficiência e transtornos globais de desenvolvimento. 
2. Oferecimento de TA - Tecnologia Assistiva.

3. Execução de adequações e elaboração de materiais didáticos e pedagógicos, tendo em vista as necessidades específicas dos alunos.

4. Orientações aos familiares para que compreendam a necessidade de suas participações no processo de inclusão de seus filhos, porque influenciam na qualidade dos resultados a serem desenvolvidos no processo de ensino e aprendizagem do aluno com necessidades especiais.

5. Estas orientações à família são realizadas no início e no final do ano, individualmente. Trimestralmente, os pais participam da reunião de pais do ensino fundamental.

6. Os atendimentos também acontecem na sala de AEE e são oferecidos no contra turno do horário escolar do aluno.

7. Quando a criança se encontra impossibilitada de frequentar a escola, por razão de problemas de saúde, a escola garante o atendimento domiciliar para que a criança mantenha a continuidade de seu processo de aprendizagem.

Consideramos que fundamentalmente, em nosso estudo do caso deste aluno de NEE, a relação humana e afetiva observada entre os alunos acontecia significativamente, pois ao chegar em sala de aula, o aluno especial era recebido pelos colegas com muito carinho, seu sorriso de felicidade era evidente na troca de atenção com as demais crianças. É possível considerar que a inclusão também é positiva para as demais crianças e para suas famílias, pois ao conhecerem e conviverem com o aluno especial, muitas barreiras e preconceitos são superados e, paulatinamente, constitui-se 
naturalizada a participação integrada tanto dos familiares quanto dos alunos, sendo que que essa integração tende a ser refletida na sociedade.

\section{Da Sensibilidade Ético-Política à Condição Humana}

Pessoas com deficiência são, antes de mais nada, pessoas que lutam por seus direitos, que valorizam o respeito pela dignidade, pela autonomia individual, pela plena e efetiva participação e inclusão na sociedade e pela igualdade de oportunidades, evidenciando, portanto, que a deficiência é apenas mais uma característica da condição humana (FERREIRA, 2010). A ação humana do educador o constitui como agente político-social, na medida em que se identifica com sua prática docente, desenvolve a sua alteridade e sua autoria, constituindo sua identidade docente. "Na ação, a existência do agente é, de certo modo, intensificada e resulta necessariamente prazer. Assim, ninguém age sem que (agindo) manifeste o seu latente" (ARENDT, 2005, p. 188).

A cada dia e em cada instituição de ensino, professores das diversas áreas estão desenvolvendo suas próprias concepções e percepções de sua profissão, nas trocas de conhecimentos com seus alunos, seus colegas de trabalho, nos grupos de pesquisa, na sua comunidade local, elaborando e reelaborando sua "teia" de relações, com as quais se constitui professor e reciprocamente contribui na formação do seu grupo social.

A alteridade humana é crucial para nossa pluralidade, porque propicia a nossa distinção e nossa singularidade, relembrando-nos de que não somos meros objetos concretos de nossa existência, somos seres humanos inseridos na "teia" das relações 
humanas. "Cada ser humano traz consigo sua própria teia de relações, as quais influenciam as teias dos demais, do grupo em que está se inserindo" (Ibidem, p.197).

Para Arendt (2005), a condição dos seres humanos demonstra sua insegurança com relação ao seu futuro e estão sendo arremessados para dentro de si mesmos, pois sua individualidade é trocada pelo individualismo.

A experiência humana perde seu significado a medida que, o pensamento tornase mera previsão de consequências, tendo em vista a sua dependência de aparelhos eletrônicos que maximizam os resultados. Tal processo infere na natureza humana uma estagnação, porque sua atividade torna-se mecânica e automatizada, o ser humano torna-se nesta "rede" social um número estatístico, matemático e racionalizado.

Para que consigamos manter nossa individualidade, mediante os diversas padrões culturais que surgem historicamente, precisamos ora, atualizarmo-nos para acompanhar as novas gerações, ora mantermos a criticidade de nossa alteridade. “Tornar-se humano é tornar-se individual, e nós nos tornamos individuais sob a direção dos padrões culturais, sistemas de significados criados historicamente em termos dos quais damos forma, ordem, objetivo e direção às nossas vidas" (GEERTZ, 1989, p.37). Manter-se atuante num sistema social, requer desenvolver relações entre nossos valores e princípios, adequando-as às novas realidades. Nós educadores precisamos estar em contínua formação, porque precisamos subsidiar nossa criticidade.

Conforme a Declaração Universal dos Diretos Humanos (1948), o ideal comum a ser atingido por todos os povos e todas as nações possui como objetivo: "Que cada indivíduo e cada órgão da sociedade, tendo sempre em mente esta Declaração, se esforce, através do ensino e da educação, por promover o respeito a esses direitos e 
liberdades, e, pela adoção de medidas progressivas de caráter nacional e internacional" (ONU, 1948).

O preâmbulo da Declaração Universal dos Direitos Humanos centraliza o papel do ensino e da educação, por possuir a responsabilidade da ação ético-política das suas instituições de ensino que formam educadores, porque precisam pautar-se na premissa da formação da dignidade humana. As nossas escolhas e as nossas decisões são como ondulações que se desdobram no grupo social que convivemos. Muitas vezes são pequenas atitudes locais, que somadas tornam-se pontos de referências que influenciam e suscitam as transformações.

A responsabilidade do docente como agente político-social, torna-se imprescindível, porque em nossa atualidade: o imediatismo e o espírito competitivo são valores e saberes que devem ser criticamente analisados. Mediante tais concretudes, a formação docente precisa ser simultaneamente técnica e política. Técnica pelo investimento em pesquisa que vise imbricar a Pós-Graduação e a Graduação com o intuito de atualizar estratégias que articulem a fundamentação teórica com as práticas educativas. Política pela intencionalidade crítica de compreender as necessidades específicas de cada contexto e direcionar ações adequadas que conduzam melhorias.

\section{Considerações finais: sobre uma perspectiva de nossa contemporaneidade}

Em nosso atual contexto uma perspectiva construtiva de educação seria o resgate de nossa diversidade e de nossa integridade humana. O papel da Educação situase na possibilidade da inclusão social, da diminuição das desigualdades e da discriminação para com as pessoas que não tiveram acesso ao ensino, ao trabalho, aos seus direitos e aos meios culturais, por exemplo, pela possibilidade de desenvolver suas sensibilidades, por meio de um tempo para desfrutar e apreciar uma forma de arte, um 
tempo de lazer e estar com a família. Em nossa atualidade social e histórica, o ideal educativo tem sido o direito de se conviver uma existência com diversidade e dignidade humana.

Os fundamentos da formação humana atravessam os séculos, devido à permanência de uma característica que nos delineia no percurso de nossa história, ou seja, a nossa natureza de estarmos sempre buscando aprimorar o presente. A postura ética só pode ser estabelecida por meio de um processo permanente de decifração do sentido da existência humana, que se desdobra no tecido social e no tempo histórico, a partir de referências econômicas, políticas, sociais e culturais. Contudo, convivemos com os valores morais externos a nossa vontade, com caráter normativo e prescritivo, quase ditando como nossas ações devem ser praticadas. (SEVERINO, 2011).

A subjetividade humana é o toque diferencial que renova e inova a prática educativa, quando se incentiva a autonomia e a confiança no aluno, mediante seu desenvolvimento em seus estudos, pois se trata de uma maneira didático-pedagógica de conduzi-lo a uma aprendizagem significativa, para sua vida pessoal e profissional. Conforme Cunha (2001, p. 88): “Cabe reafirmar que os saberes constitutivos da profissão docente implicam consciência, compreensão e conhecimento. Sobre essas bases é que se pode estabelecer a reflexividade e, com ela, uma perspectiva mais emancipatória da profissão".

Estes saberes contribuem na formação humana, pois caracterizam a responsabilidade política e social da docência e das instituições em todos os níveis de ensino. Nesta pesquisa, em específico, analisamos a educação especial no ensino fundamental, essa transformação se desenvolve entre crianças que iniciam seus primeiros contatos sociais, assim como, redistribuem suas novas experiências com suas famílias, de maneira que uma escola inclusiva é a essência da transformação para uma sociedade inclusiva; pois questões como a acessibilidade, a estrutura e infraestrutura 
para atender as necessidades de um aluno especial, as dificuldades de relacionamento entre as crianças em sala de aula, mediante a presença de uma criança especial, as relações entre as famílias, as oportunidades de mercado de trabalho, de lazer e de cultura, enfim, descortinam-se novos comprometimentos nas relações entre as pessoas que despertam nossa sensibilidade ético-política em relação à nossa condição humana.

\section{Referências}

ALMEIDA, Marina da Silveira Rodrigues. Manual informativo para pais sobre educação inclusiva número 20 - a diversidade na escola: possibilidades e limites. Revista Pedagógica Pátio, Ano V, n. 20, fev./abr. Porto Alegre: Ed. Artemed, 2002.

ARENDT, Hanna. A condição bumana. Rio de Janeiro: Forense Universitária, 2005.

BRASIL. Ministério da Saúde. Secretaria de Atenção à Saúde. Departamento de Atenção Básica. Saúde na escola. Ministério da Saúde, Secretaria de Atenção à Saúde, Departamento de Atenção Básica. - Brasília: Ministério da Saúde, 2009a. Disponível em: http://bvsms.saude.gov.br/bvs/publicacoes/cadernos atencao basica 24.pdf Acesso em: 09 out. 2018.

BRASIL. Decreto legislativo no 198, de 13 de junho de 2001, Disponível em: http://www.planalto.gov.br Acesso em:15 dez. 2016b.

BRASIL. decreto ${ }^{\circ} 5.626$, de 22 de dezembro de 2005. Regulamenta a Lei no 10.436, de 24 de abril de 2002, que dispõe sobre a Língua Brasileira de Sinais - Libras, e o art. 
FORMAÇÃO DE EDUCADORES E A EDUCAÇÃO INCLUSIVA: DA SENSIBILIDADE ÉTICO-

POLÍTICA À CONDIÇÃO HUMANA

18 da Lei no 10.098, de 19 de dezembro de 2000. Disponível em: <http://www.planalto.gov.br> Acesso em: 06 dez. 2016c.

BRASIL. Decreto N N $^{\circ} .611$, de 17 de novembro de 2011. Dispõe sobre a educação especial, o atendimento educacional especializado e dá outras providências.

Disponível em: <http:/www.planalto.gov.br> Acesso em: 16 dez. $2016 \mathrm{~d}$.

CÂMARA DOS DEPUTADOS - EDUCAÇÃO E CULTURA. Câmara aprova o ensino de Libras e Braile. Disponível em: <http://www.2.camara.leg.br>. Acesso em: 06 dez. 2016.

CUNHA, Maria Isabel Cunha da. Professor do ensino superior: identidade, docência e formação. Morosi et al. (Org.). Brasília: Plano, 2001.

FRASER, Nancy. Reconhecimento sem Ética? Revista Lua Nova, São Paulo, n. 70 p. 101-138, 2007.

FERREIRA, Antonio José A. Convenção sobre os Direitos das Pessoas com Deficiência muda a vida das pessoas, In Convenção Sobre Os Direitos Das Pessoas Com Deficiência: Protocolo Facultativo à Convenção sobre os Direitos das Pessoas com Deficiência: Decreto Legislativo $n^{\circ}$ 186, de 09 de julho de 2008: Decreto $n^{\circ}$ 6.949, de 25 de agosto de 2009. $4^{a}$ Ed., rev. e atual. Brasília: Secretaria de Direitos Humanos, 2010. Disponível em: <http://.www.pessoacom deficiencia.gov.br> Acesso em: 20 nov. 2016.

GEERTZ, Clifford. A interpretação das culturas. Rio de Janeiro: LTC, 1989.

CARDOSO, Rodrigo. É o fim do braile? Tecnologias facilitam acesso dos cegos ao conbecimento, mas os afastam da leitura pelo tato. Publicado em: 22 out. 2010. Disponível em: https://istoe.com.br/107318 E+O+FIM+DO+BRAILE+/ Acesso em: 10 out. 2018.

MARIN, Márcia, MARETTI, Márcia, Ensino Colaborativo: Estratégia de Ensino para a Inclusão Escolar, Anais do I Seminário de Inclusão Escolar: práticas e diálogos, Universidade do Estado do Rio de Janeiro, Cap. -UERJ, 21 a 23 de outubro de 2014.

MEDEIROS, Ana Maria. Os Cegos e as Novas Tecnologias - O Contexto dos Anos 90, publicado em 14 jul. 2010. Acervo do PORTAL PLANNETA EDUCAÇÃO. Disponível em: 
http://acervo.plannetaeducacao.com.br/portal/artigo.asp?artigo=1876 Acesso em: 11 março 2016.

NÚÑEZ, María Elena De Los Milagros Saavedra [et al] Estudio De Caso De Dos Experiencias Ganadoras Del III Concurso Nacional Experiencias Exitosas En Educación Inclusiva. Pontificia Universidad Católica Del Perú Escuela De Posgrado - Lima, Perú, 2014.

ONU Organização das Nações Unidas. Declaração Universal dos Direitos Humanos 1948. Disponível em: <http://unesdoc.unesco.org> Acesso em: 20 set. 2016.

RABELLO, Suzana; MOT'TI, Telma Flores Genaro; GASPARETTTO, Maria Elisabete Rodrigues Freire. Avaliação educacional por meio do teste IAR em escolares com cegueira. Rev. bras. educ. espec., Marília, v. 13, n. 2, p. 281-290, Aug. 2007. Disponível em: $\quad<$ http://www.scielo.br/scielo.php?script=sci_arttext\&pid=S141365382007000200009\&lng=en\&nrm=iso $>$.

Acesso em: 10 out. 2018. http://dx.doi.org/10.1590/S1413-65382007000200009.

RIBEIRO, Vladimir, Saúde bucal de SBC atende pacientes com necessidades especiais. Publicado em: 02 jul. 2015. Disponível em: <http://www.abcdoabc.com.br>.Acesso em: 04 nov. 2016.

SEVERINO, Antonio Joaquim. A Filosofia contemporânea do Brasil: conhecimento, politica e educação. $6^{\mathrm{a}}$ edição. Petrópolis RJ.: Vozes, 2011.

UNESCO Declaração de salamanca sobre princípios, política e práticas na área das necessidades educativas especiais 1994. UNESDOC publicado em 1988. Disponível em: 
POLÍTICA À CONDIČ̃̃ HUMANA

http://unesdoc.unesco.org/images/0013/001393/139394por.pdf Acesso em: 9 out. 2018.

UNESCO, Fórum Mundial de Educação. UNESDOC. Publicado em 2015. Disponível em: http://unesdoc.unesco.org/images/0018/001871/187129por.pdf Acesso em: 09 set. 2016.

UNICEF Um mundo melhorpara as crianças após 2015. Publicado em 2015. Disponível em: www.unicef.org/.../files/Post 2015 OWG review CR FINAL port.pdf Acesso em: 08 set. 2016.

recebido em 20 fev. 2017 / aprovado em 05 fev. 2018

\section{Para referenciar este texto:}

SOARES, M. Formação de educadores e a educação inclusiva: da sensibilidade ético-política à condição humana. Cadernos de Pós-graduação, São Paulo, v. 17, n.2, p. 143-166, jul./dez. 2018. Disponível em: <https://doi.org/10.5585/cpg.v17n2.7169> 


\title{
DESAFIOS E SURPRESAS DA INCLUSÃO DE UMA CRIANÇA CEGA EM
}

\author{
SALA DE AULA
}

\section{CHALLENGES AND SURPRISES OF THE INCLUSION OF A BLIND CHILD IN}

\section{A CLASSROOM}

\begin{abstract}
Valquiria Bertuzzi Veronesi
Mestra em Gestão e Práticas Educacionais pela Universidade Nove de Julho. São Paulo - SP - Brasil valquiriabv@uol.com.br

Francisca Eleodora Santos Severino Doutora em Ciências da Comunicação pela Universidade de São Paulo São Paulo - SP - Brasil frasev@uol.com.br
\end{abstract}

Resumo: Este ensaio retrata a experiência de uma professora que tendo atuado na gestão escolar por doze anos retorna à sala de aula de uma turma de alfabetização com um aluno cego. A proposta tem como objetivos principais promover a reflexão acerca dos desafios e potencialidades decorrentes da inclusão escolar de uma criança cega e contribuir para o desenvolvimento integral dos alunos. Visando alcançar os objetivos, recorreu-se a estudo bibliográfico, rodas de conversas com as crianças, estabelecimento de parcerias e planejamento ressignificado do trabalho para uma aprendizagem ampla e prazerosa. O aporte teórico utilizado perpassa pela legislação e por referências como Freire (1989,1996), Fischer, (1987), Santaella (2012) e Galvão (1995). Como resultados obtidos, destaca-se o estreitamento de vínculo entre todos os envolvidos e as vivências proporcionadas como responsáveis em potencializar possibilidades para novas conquistas e superações. Um cenário de aprendizagem bilateral em que todos foram favorecidos.

Palavras-chave: Educação. Inclusão. Deficiência visual. Arte.

Abstract: This essay portrays the experience of a teacher who has served in school management for twelve years returns to the classroom of a literacy class with a blind student. The main

Cadernos de Pós-graduação, São Paulo, v. 17, n. 2, p. 167-182, jul./dez. 2018. 
objective of the proposal is to promote reflection on the challenges and potentialities resulting from the school inclusion of a blind child and contribute to the integral development of the students. In order to reach the objectives, we used a bibliographic study, a series of conversations with the children, establishing partnerships and re-signification of the work for a wide and pleasant learning. The theoretical contribution used goes through legislation and references such as Freire (1989, 1996), Fischer, (1987), Santaella. (2012) and Galvão (1995). As a result, the link between all those involved and the experiences provided as responsible for potentializing possibilities for new achievements and overcomings is highlighted. A bilateral learning scenario in which all were favored.

Keywords: Education. Inclusion. Visual disability. Art.

017: Ano novo, vida nova, a professora retorna à sala de aula depois de ter
trabalhado 12 anos como gestora na rede pública. Com atribuições diversas, dentre elas gerir e organizar a escola, atender famílias, contribuir com a formação de professores e, claro, sempre com o foco no maior objetivo, ou seja, direcionar todas as ações da escola e dos respectivos envolvidos para a aprendizagem e para o melhor desenvolvimento das crianças.

Mestranda, com pesquisa voltada para os Saberes e faz̧eres dos professores de Educação Infantil em Artes Visuais, inicia 2017 com uma sala de primeiro ano, muito empolgada com essa fase de alfabetização e com a cabeça fervilhando de ideias, pretende colocar em prática tudo aquilo que estudou e contribuiu ao acompanhar professores, nos intensos e produtivos anos anteriores.

Ao chegar à escola e apropriar-se das características dos seus futuros alunos, a professora depara-se com a primeira e grande surpresa: havia entre eles um aluno cego, algo bastante previsível em uma rede inclusiva.

Superada a surpresa, veem as implicações e preocupações das desvantagens que pessoas cegas ou com baixa visão estão em relação às videntes, tendo em vista a predominância de estímulos visuais que nos cercam diariamente. Considerando que, por 
receberem informações ou processarem seus conhecimentos de forma diversa, provocam várias dúvidas e inquietações e dentre elas estão: como organizar as condições educacionais para uma criança desenvolver-se integralmente? De que maneira podem ser asseguradas ações condizentes a uma educação inclusiva?

Para termos uma escola inclusiva há que se atender às necessidades educacionais de cada aluno, dessa forma, a professora busca estratégias e recursos para realizar um trabalho que contemple tanto o aluno cego quanto os demais, proporcionando experiências nas diversas linguagens e com estímulos sensoriais que contribuem significativamente para a aprendizagem de todos, sobretudo do aluno que será denominado JV.

\section{$1 \mathrm{O}$ reencontro com a sala de aula e o desafio da inclusão de uma criança cega}

Segundo Sá, Campos e Silva (2007), a cegueira é "uma alteração grave ou total de uma ou mais funções elementares da visão que afeta de modo irremediável a capacidade de perceber cor, tamanho, distância, forma, posição ou movimento em um campo mais ou menos abrangente." (p. 15). Assim, pode-se ressaltar que, uma vez que a capacidade do sistema visual preservado é responsável por absorver mais de $80 \%$ dos estímulos que estão disponíveis nos ambientes (SÁ, CAMPOS e SILVA, 2007), tanto a pessoa cega quanto a pessoa com baixa visão irá captar uma restrita quantidade de informações advindas do meio ambiente.

Visando atuar de acordo com as políticas educacionais vigentes, o esforço de uma educação inclusiva é bilateral (PONTES, 2008), sendo imprescindível para esse cenário contar com o trabalho coletivo da escola e da família, articulando o trabalho do professor com outros profissionais parceiros (estagiária e especialistas) e os recursos materiais necessários. 
Para garantir o acesso, permanência e qualidade do atendimento e educação à pessoa com deficiência, a Constituição Federal de 1988 (BRASIL, 1988) assegura esse direito a todos em seu Capítulo III, Seção I, artigo 206, bem como a Declaração de Salamanca (1994) garante o atendimento dessas crianças em escolas regulares, cujas práticas são voltadas para elas e suas especificidades.

Diante dessa perspectiva, o município de Santo André adere ao princípio inclusivo desde 1989, atendendo pessoas com deficiências nas salas regulares de ensino. A partir de 1997, ocorre a implantação de uma cultura de "educação inclusiva" para que o trabalho com as crianças, jovens e adultos com deficiências seja ampliado e efetivo. Em 1998, cria-se o Centro de Atenção ao Desenvolvimento Educacional (CADE). Esse serviço da Secretaria de Educação atende a todas as etapas de ensino, desde a Educação Infantil até a Educação de Jovens e adultos, fornecendo acompanhamento e assessoria pedagógica, facilitando o acesso e permanência do aluno com deficiência, que está devidamente matriculado na rede municipal de ensino.

Isto posto, a professora organiza um projeto de ações e práticas pedagógicas, pautadas em princípios que delineiam uma educação integral, visando abarcar a integralidade do ser, conforme esclarece Wallon (In: GALVÃO, 1995, p.29): "O homem é determinado fisiológica e socialmente, sujeito, portanto, a uma dupla história, a de suas disposições internas e a das situações exteriores que encontra ao longo de sua existência". Wallon recorre ao materialismo dialético que contribui para superar os paradoxos que dificultam a compreensão de realidade, a qual se apresenta em constante transformação. Preocupado com a infância, Wallon entende que a escola necessita considerar a criança um ser inteiro, que interage com o meio em que vive, portanto um ser ativo e social.

A sociedade atual, segundo Bauman (2009), não se pauta mais em estágios sólidos, previsíveis, os quais são cunhados pela durabilidade e a lógica. Por conseguinte, 
o trabalho com a diversidade, em uma escola inclusiva, é compatível com essa nossa sociedade contemporânea; que Bauman (2009) retrata pela fluidez, incertezas e imprevisibilidade, as quais conduzirão a novas práticas educacionais tão necessárias à aproximação das relações que se estabelecem entre os conhecimentos e os legítimos sujeitos que a compõem.

Frente ao desafio de buscar um caminho adequado à inclusão de uma criança cega ao grupo de crianças da mesma idade, que cursam a escola básica, a professora segue em frente refletindo sobre a exigência de encontrar referências conceituais, que lhe permitam trabalhar em prol da inclusão e aprendizado qualificado dessa criança; contudo, sem descuidar dos outros alunos, que demandam atenção para a apreensão dos conteúdos curriculares adequados à série que cursam.

Assim sendo, a professora demanda esforços para contemplar e integrar as diversas linguagens, sobretudo as Artes Visuais que possibilitam o exercício da aprendizagem ativa, na qual o aluno é protagonista de seu aprendizado. Nessa proposta, o aluno é levado a apropriar-se de dinâmicas interativas que tem por referência as balizas dialógicas traçadas pela professora. Profissional que, no entanto, respeita o tempo, a criatividade e as escolhas dos alunos. Distanciando-se assim de práticas tradicionais, centradas no adulto, na transmissão e reprodução passiva dos conhecimentos.

A partir de uma nova dinâmica metodológica que pressupõe o reconhecimento do colega cego, todos os alunos e também a professora encontram, com o apoio da Arte aplicada à educação, a mediação necessária para a compreensão dessa condição especial, e, enfim sustentados pela reciprocidade na relação dialógica entre o eu e o outro, seguem encontrando a síntese identitária necessária à aprendizagem.

Processos de criação envolvendo as crianças tornou possível estabelecer um liame entre a professora e seus alunos. Entretanto, este é um momento em que aflora a contradição entre a sua condição humana de não se sentir preparada para o desafio 
do ensino em condição diferenciada, e o ser professora segura de suas ações, que promoverão as condições necessárias para a objetivação da identidade na apreensão dos conteúdos curriculares. Em Freire (1996) ela obtém encorajamento necessário para a superação da zona de conforto inicial.

O meu respeito de professor à pessoa do educando, à sua curiosidade, à sua timidez, que não devo agravar com procedimentos inibidores exige de mim o cultivo da humildade e da tolerância. Como posso respeitar a curiosidade do educando se, carente de humildade e da real compreensão do papel da ignorância na busca do saber, temo revelar o meu desconhecimento? Como ser educador, sobretudo numa perspectiva progressista, sem aprender, com maior ou menor esforço, a conviver com os diferentes? Como ser educador, se não desenvolvo em mim a indispensável amorosidade aos educandos com quem me comprometo e ao próprio processo formador de que sou parte? Não posso desgostar do que faço sob pena de não fazê-lo bem. (p. 74 e 75)

Tendo como objetivo não restringir ou limitar o aluno ainda mais do que a própria cegueira já o faz, os estímulos e as experiências devem caminhar para a quebra de paradigmas, com ousadia e coerência. Dessa forma, a professora planeja seu trabalho tendo como parâmetro as reflexões sobre sua prática; pautada em princípios de uma educação de qualidade, vivenciando as diversas linguagens, valorizando a cultura da infância, a continuidade educativa entre Educação Infantil e Ensino Fundamental, e assegurando o direito de todos ao acesso e construção de conhecimentos.

Barros (2003) reafirma esses princípios: "[...] entendemos que a ausência de uma discussão sobre a apropriação de diferentes linguagens favorece a permanência da desigualdade de acesso ao patrimônio imaterial socialmente produzido". (p.22). A ausência de reflexão sobre a necessidade de inserção de novas abordagens na escola é para esse autor uma estratégia de manutenção do status quo, estratégia de subordinação e inferiorização de segmentos sociais menos favorecidos. Esse padrão de escola desqua- 
lificada é imposto historicamente como um modelo dual de ensino, derivado dos segmentos sociais dominantes, pois são eles que controlam o acesso desigual e combinado ao conhecimento e à riqueza em escala planetária. $\mathrm{O}$ acesso à Arte e à apropriação das possibilidades pedagógicas que ela oferece é concedido, de modo geral, apenas a essas elites. A concepção de uma escolaridade dual impossibilita a exploração da polissemia nos limites do significado, em diferentes linguagens. Barros (2003) ainda esclarece que:

Nesse contexto, inviabiliza-se o acesso da maioria da população às fronteiras do sentido, em linguagens constituídas modernamente nas manifestações de natureza estética filmográfica, videográfica, infográfica somente acessíveis à compreensão como tal pelo tratamento singular de sua especificidade discursiva, para o qual a escola deve cumprir um papel mediador decisivo. (p.22).

Em certos aspectos, a Arte é fundamental na compreensão da realidade em sua concretude e na vida do sujeito em devir social. A Arte no contexto desse devir, em geral ou inserido no espaço escolar, desempenha a privilegiada função de viabilizar a produção de significações que orientam a aprendizagem, seja no âmbito pessoal, seja no âmbito coletivo. Sendo assim, a Arte na compreensão de Fischer (1987, p. 19) “[...] jogando com sombras ou trazendo luzes a arte jamais é uma descrição clínica do real. Sua função concerne sempre ao homem total, capacita o eu a identificar-se com a vida dos outros, capacita-o a incorporar a si, aquilo que não é, mas tem possibilidade de ser”.

Refletindo, pois, sobre a função da Arte como aquela que destina-se a clarear as ideias e incentivar atitudes necessárias, a tornar as crianças capazes de conhecer e transformar o mundo ampliando os seus horizontes, e também os horizontes coletivos, a professora alfabetizadora está convicta que a Arte é necessária à inserção do menino cego no ambiente escolar, haja vista que instigará o menino à reflexão. Ela cria então a estratégia das surpresinhas, trazendo para a sala de aula uma caixinha com alguns objetos que terão a função de instigar a criança, ampliando seus horizontes. 
Preocupada com a alfabetização, uma vez que a turminha inicia o $1^{\circ}$ ano do $1^{\circ}$ ciclo do Ensino fundamental, mas atenta também a alicerçar a necessária e significativa leitura de mundo, antes da leitura das letras e das palavras, conforme nos ensina Freire (1989): "A leitura do mundo precede a leitura da palavra, daí que a posterior leitura desta não possa prescindir da continuidade da leitura daquele. Linguagem e realidade se prendem dinamicamente" (p. 9). A professora sustenta-se nos preceitos de Freire para proporcionar um momento significativo na infância das crianças, trabalhando não somente a leitura, a escrita, os cálculos, mas as vivências com leitura de imagens, produções artísticas, dança, música, literatura e outros encantamentos existentes ao nosso redor, que são permitidos ao imaginário infantil e a quem dele tem fartas memórias.

Com a leitura de imagens, que se apresentam mediadas por obras de Arte, sejam elas da pintura, da literatura ou da fotografia; disponíveis no acervo da escola, na internet e quando possível, em visita a Museus; a professora propõe-se a oferecer oficinas para que os alunos se habituem com a metodologia ativa, que os tornam protagonistas do agir educativo. Essa ideia converge com a concepção de que a aprendizagem não é um processo realizado pelo outro e sim pela mediação crítica do sujeito histórico com o mundo, ou seja, reportando-se à perspectiva de aprendizagem da autonomia, da curiosidade e de força criadora defendida por Freire (1996), quando diz:

É que o processo de aprender, em que historicamente descobrimos que era possível ensinar como tarefa não apenas embutida no aprender, mas perfilada em si, com relação a aprender, é um processo que pode deflagrar no aprendiz uma curiosidade crescente, que pode torná-lo mais e mais criador. O que quero dizer é o seguinte: quanto mais criticamente se exerça a capacidade de aprender tanto mais se constrói e desenvolve o que venho chamando "curiosidade epistemológica", sem a qual não alcançamos o conhecimento cabal do objeto. (p.27)

Por conseguinte, a professora organiza o acolhimento das crianças com brincadeiras que mobilizam os sentidos, como jogos corporais, músicas, histórias interativas, 
caixa surpresa (com elementos a serem sentidos por meio do tato ou olfato), entre outros. As propostas desafiadoras, que incitam a criação e ludicidade envolvendo as crianças, tornaram possível estabelecer um liame entre a professora e seus alunos.

No início, embora JV demonstrasse interesse em participar de tudo, apresentava um comportamento um pouco arredio, impaciente e egocentrado; não respondia quando alguém dirigia-lhe a palavra, não aceitava o toque ou até mesmo a aproximação das pessoas. Com empurrões e gritos: Sai da frente! Espantava qualquer pessoa que estivesse em seu caminho. Mostrava-se também bastante impaciente e intolerante com a presença dos colegas, falando alto e querendo ser o primeiro a todo o momento. Gradativamente, a professora e a estagiária, por meio do diálogo e vivências, mostram-lhe a importância de ser gentil, pedir licença, falar mais baixo e esperar sua vez.

\section{Modos de conceber e trabalhar com uma criança cega: surpresas e alegria para todas as crianças}

As aulas vão transcorrendo em meio à agitação do grupo, às vivências de diferentes linguagens, às conversas e às brincadeiras. Para envolver a todos os alunos, sobretudo JV, a professora faz uso de diferentes estratégias, traz muitos elementos à escola para que JV possa tatear, sentir e experimentar cada centímetro desses diversos materiais oferecidos e trabalhados com eles. Algumas estratégias foram pensadas e preparadas com o propósito da inserção de JV no processo que configura o espaço da sala de aula. Tais estratégias foram denominadas surpresinhas, algumas das quais foram reservadas para aproximá-lo da construção de conceitos complexos para alguém que possui outra maneira de viver e estar nesse mundo.

Elaborar conceitos sobre objetos, sentimentos, aromas, animais, plantas visando auxiliar a aprendizagem de uma pessoa cega não é um desafio fácil. Aproximar 
objetos, tais como: miniaturas ou réplicas para que a pessoa cega possa ter contato e apropriar-se desses conhecimentos que farão sentido para ela é uma tarefa necessária, uma vez que tais objetos se configuram como elementos mediadores na comunicação dialógica entre os sujeitos de aprendizagem. Sendo assim, a professora sempre apresenta objetos para contextualizar o trabalho desenvolvido: animais em miniatura, girassol de plástico, caixas, sementes, alimentos, elementos da natureza, entre outros.

A caixa surpresa, estratégia que causa grande euforia entre as crianças, é passada para todos os alunos tatearem os objetos nela colocados e as crianças vão falando ao ouvido da professora quais são suas hipóteses em relação ao(s) objeto(s) constante(s) na caixa. A partir do momento em que todos tiveram a oportunidade de explorá-la, o segredo é desvelado pela professora ou por quem trouxe a surpresa. Essa estratégia, além de encantar e desafiar as crianças, pois cada uma fica responsável em trazer um objeto surpresa para a descoberta da semana, as crianças desenvolvem a percepção tátil, a imaginação e a oralidade, dentre outras habilidades.

Algo singular nas vivências deste grupo é que, principalmente na atividade da caixa surpresa, as percepções de um aluno que não enxerga e possui um jeito diferente de caracterizar ou entender os objetos, muito diferente das demais crianças, são ouvidas. Um dia, por exemplo, JV disse que um tubo de balas era um objeto que não podia ficar em pé, ou seja, ele percebeu que suas pontas eram arredondadas e não permitiam o apoio desse objeto em uma superfície plana. Esse tipo de observação não é feita costumeiramente pelas crianças videntes, elas vão direto ao ponto, nomeiam o objeto e não ficam verbalizando suas características, arriscam e dizem o que acreditam que seja aquele determinado objeto ou assumem que o desconhecem.

A professora procura adaptar todas as atividades para o aluno, utilizando texturas, saliências que causam grande desafio e autonomia. Utiliza cola quente, carretilha, diferentes tipos de papeis, massinha de modelar, argila, tinta, palito, canudo, barbante, 
tecido e outros materiais para registrar, contar e relacionar. Todas as experiências perpassam por situações concretas para que se possa chegar às representações abstratas. JV é uma criança muito esperta, tem interesse por tudo que é proposto pela professora e vibra dizendo o que gostou de fazer e em que deseja participar.

Para uma criança cega, a localização espacial é algo muito importante, pois facilita o desenvolvimento de sua autonomia, portanto é necessário informar ao aluno o que irão realizar, o que existe no caminho e ao seu redor. É preciso descrever tudo com riqueza de detalhes, visando facilitar seu acesso e sua compreensão.

JV caminha com autonomia pelos espaços escolares, inicialmente, utilizava somente o piso podotátil e o corrimão. Atualmente, já faz uso da bengala e apresenta tamanha segurança que a professora precisa solicitar-lhe que aguarde o grupo, que não fique tão à frente ou até mesmo que não corra.

No parque, a exploração é intensa. Inicialmente, a professora percorreu todos os brinquedos com JV, dando pistas de como utilizá-los com segurança, os quais foram tateados e calculados por JV para captar a altura, as formas, como proceder e suas possibilidades. Certo dia, atreveram-se a uma subida na árvore, mesmo com alguma limitação, a sensação foi bastante prazerosa e desafiadora. Com o passar do tempo, JV diverte-se em companhia dos colegas, perambulando pelos brinquedos preferidos e arriscando algumas manobras mais ousadas. Esses resultados confirmam o que nos ensina Vigotski (1998) a respeito da zona de desenvolvimento proximal: “[...] aquilo que uma criança pode fazer com assistência hoje, ela será capaz de fazer sozinha amanhã.” (p. 113).

Quando a tinta foi utilizada pela primeira vez, JV não aceitou, ficou desconfiado, preferindo utilizar o pincel. Entretanto, bastou familiarizar-se com sua textura, para empolgar-se com a proposta e interessar-se pela exploração de tintas, melecas em 
diferentes papeis, que na maioria das vezes, deflagra sorrisos e gargalhadas, resultados de uma deliciosa sensação de quem faz uma travessura.

Em uma conversa com a professora de educação física a respeito de suas dificuldades com JV, descobre-se que ele apresentava resistência em virar cambalhota. Com isso, a professora, mais uma vez desafiada, convida JV a fazer uma brincadeira que seu pai fazia com ela quando criança, a brincadeira consiste em um adulto girar uma criança entre suas pernas, dando uma cambalhota no ar. A princípio, ele ficou um pouco apreensivo, mas quando a professora fez com que ele percebesse, tateando, os movimentos da brincadeira realizados com outras crianças, ele sentiu-se mais seguro e aceitou o desafio. Podemos constatar que o estreitamento de vínculo favorece a confiança e ao ser oferecida uma nova vivência, obtém-se mais uma superação.

Outro conceito bastante complexo a ser trabalhado com pessoas cegas ou baixa visão é a construção do conceito de cores. Para a elaboração do conceito de cada cor, a professora utiliza uma grande diversidade de recursos com fortes características olfativas, gustativas e táteis, como por exemplo: elementos da natureza (folhas, grama, ervas medicinais) para o conceito do verde; frutas (maracujá, laranja, abacaxi) e outros alimentos e temperos (macarrão, mostarda), para construir o conceito do amarelo; terra, lascas de canela, café, chocolate para construir o conceito do marrom e assim, sucessivamente. Com muito aroma, textura e gostosura conseguem ressignificar esse conteúdo.

Trabalhar leitura de imagem com uma turma que acolhe um aluno cego, a princípio, pode parecer inadequado ou impossível. No entanto, há que se considerar a definição de leitura de imagem, segundo Santaella (2012):

Quando se trata de explicar as formas específicas de representação, de acesso e de conhecimento da realidade que as imagens suscitam, nada impede que as imagens sejam traduzidas na linguagem que utilizamos para nos comunicar, a saber a linguagem verbal (p. 12). 
Na leitura de imagem da obra Os Retirantes, de Cândido Portinari (1903-1962), conforme a prática utilizada pela a professora, as crianças vão descrevendo o que veem para que JV possa se apropriar dos elementos observados e descritos pelas crianças e assim, os alunos passam a captar as imagens, traduzindo-as e comtemplando-as para JV. O grupo ficou muito interessado pela vida de Portinari e a referida obra causou várias sensações nas crianças, no entanto, é JV quem faz reflexões importantes sobre a seca e o sofrimento do povo do sertão. JV verbaliza que lhes faltam água e comida, o que muitas vezes os levam a morte.

O Dicionário Aurélio Online traz várias definições da palavra "cego", dentre elas estão: "que tem visão perturbada", "que tem o raciocínio perturbado", "em que há escuridão", entre outros. Apenas uma delas refere-se a "estar privado da visão ou tê-la de forma reduzida". No entanto, entende-se que dentro dessa condição de escuridão, há um potencial latente que necessita ser despertado constantemente, e por meio da interação e vivência com os colegas, com a estagiária e com a professora, essa condição é reinventada, conduzindo JV a novos caminhos, ampliando possibilidades.

A relevância desse trabalho sócio-interativo é irrefutável para o pleno desenvolvimento e aprendizagem do aluno, no entanto, Bruno (1997) salienta o quão notável é também para o crescimento profissional da professora e de todos os envolvidos. Com a dinâmica de troca de saberes entre família, escola, professora, estagiária e crianças, no envolvimento ao processo educacional, potencializa os pensamentos para uma responsabilidade coletiva no ensino e aprendizagem de todos, inclusive para uma escola inclusiva.

\section{Algumas considerações}


Por meio da observação e conversas com o aluno e com a estagiária, a professora vai balizando suas práticas e reinventando novas propostas, para que JV e toda a turma adquiram mais segurança e ampliem seus conhecimentos.

Com a confiança entre todos assegurada, especialmente a de JV, a professora consegue adentrar seus pensamentos, que outrora ficavam guardados, em segredo. Com isso, vez ou outra, JV dispara, durante as conversas, o que não conhece, o que não sabe, quais experiências nunca teve e assim a professora vai "coletando" esses dados para que possa planejar suas aulas e contemplar suas necessidades, trazendo materiais novos e diversificados, objetos que JV possa sentir seu aroma, tocar ou até mesmo degustar. Ele também verbaliza seus desejos que são possíveis de realizar, como ter uma bola de guizo, fazer bolinhas de sabão e correr sem parar.

Ao longo desse primeiro semestre, percebem-se nitidamente as conquistas não só de JV, mas de todo o grupo: alunos, estagiária e professora. Cenário auspicioso, em que todos são privilegiados. Aprendendo uns com os outros, num diálogo constante, ocorre o crescimento pessoal de cada um e profissional, por parte da estagiária e da professora, que trocam constantemente suas angústias e acertos.

Durante esses prazerosos momentos, todos os envolvidos representam, de alguma forma, uma conexão entre a realidade e a compreensão que JV elabora acerca do mundo. Isso contribui para que ele e as demais crianças tenham um período de infância repleto de saberes, vivências e desafios, ou seja, de memórias que lhes serão significativas por toda a vida. 


\section{Referências}

BARROS, Armando Martins de. Práticas discursivas ao olhar: notas sobre a vidência e a cegueira na formação do Pedagogo. RJ: E-Papers Serviços Editoriais, 2003.

BAUMAN, Zygmunt. Os desafios da educação: aprender a caminhar sobre areias movediças. Cadernos de Pesquisa, v. 39, n. 127, maio/ago., 2009.

BRASIL. Constituição (1988). Constituição da República Federativa do Brasil. Brasília, DF: Senado Federal, 1988.

BRUNO, Marilda M.G. Deficiência Visual - Reflexão sobre a Prática Pedagógica. São Paulo: Laramara, 1997. Disponível em: < http://www.deficienciavisual.pt/txt-reflexao pratica pedagogica-Marilda Bruno.htm $>$. Acesso em: 13 set. 2017.

DECLARAÇÃO DE SALAMANCA. Sobre Princípios, Políticas e Práticas na Área das Necessidades Educativas Especiais, Unesco, 1994. Disponível em: < http://unesdoc. unesco.org/images /0013/ 001393/139394por.pdf>Acesso em: 28 jul. 2017.

FREIRE, Paulo. A importância do ato de ler: em três artigos que se completam. São Paulo, Autores Associados: Cortez, 1989.

FREIRE, Paulo. Pedagogia da autonomia: saberes necessários à prática educativa. São Paulo: Paz e Terra, 1996.

FISCHER, Ernest. A necessidade da arte.9. Rio de Janeiro, ed. LTC. 1987.

GALVÃO, Izabel. Henri Wallon: uma concepção dialética do desenvolvimento infantil. Petrópolis, RJ: Vozes, 1995.

PONTES, Patricia A. G. Criança e adolescente com deficiência: impossibilidade de opção pela sua educação exclusivamente no atendimento educacional especializado. In: Inclusão: Revista da Educação Especial. Secretaria de Educação Especial. v. 4, n.1, p.4148, jan/jun 2018. Brasília: Secretaria de Educação Especial/MEC. Disponível em: <http:/portal.mec. gov.br/seesp/arquivos/pdf/revinclusao5.pdf>. Acesso em: 15 set. 2017.

SANTAELLA, Lucia. Leitura de imagens. São Paulo: Editora Melhoramentos, 2012. 
SÁ, Elizabet D. de; CAMPOS, Izilda M. de; SILVA Myriam B. C. Atendimento Educacional Especializado: deficiência visual. SEESP/SEED/MEC Brasília/DF, 2007. Disponível em: <http://portal.mec.gov.br/seesp/arquivos/pdf/aee_dv.pdf>. Acesso em: 13 set. 2017.

VIGOTSKI, Lev S. A formação social da mente: o desenvolvimento dos processos psicológicos superiores. São Paulo: Martins Fontes, 1998.

recebido em 21 ago. 2017 / aprovado em 12 fev. 2018

\section{Para referenciar este texto:}

VERONESI, V. B.; SEVERINO, F. E. S. Desafios e surpresas da inclusão de uma criança cega em sala de aula. Cadernos de Pós-graduação, São Paulo, v. 17, n.2, p. 167-182, jul./dez. 2018. Disponível em: < https://doi.org/10.5585/cpg.v17n2.7733>. 


\title{
EDUCAÇÃO, COMUNICAÇÃO E MÍDIA: UMA ABORDAGEM TEÓRICA
}

\author{
EDUCATION, COMMUNICATION AND MEDIA: A THEORETICAL \\ APPROACH
}

\begin{abstract}
Douglas Branco de Camargo
Mestre em Educação pela Universidade do Oeste de Santa Catarina. Docente da Faculdade Avantis e da Clínica Psiquiátrica Bem Viver - Camboriú - SC - Brasil douglascamargo998@hotmail.com

Iris Weiduschat

Mestre em Educação pelo Pädagogische Hochschule Freiburg. Docente do Instituto Federal Catarinense. Santa Catarina - SC - Brasil irisw2008@gmail.com
\end{abstract}

Alvin Noriler

Especialista em Docência em História e Geografia pela Faculdade Avantis. Professor de Secretaria Municipal de Educação de Porto Belo. Santa Catarina - SC - Brasil alvin.noriler@gmail.com

\begin{abstract}
Resumo: Este artigo apresenta um estudo teórico e conceitual para a composição da trajetória da comunicação em educação, congregando os conceitos de cultura, mídia e comunicação humana. Os tópicos de estudo fundamentam-se principalmente em Williams (1969), Adorno (1970), Thompson (1979), Benjamim (1986), Martin-Barbero (1987), e Bauman (1975; 2012). O artigo tem o objetivo de vincular a trajetória da comunicação e mídias à educação, em especial a informática educativa importante nos processos do ensino e da aprendizagem na contemporaneidade. A metodologia de natureza qualitativa, utilizou-se da pesquisa bibliográfica com foco na perspectiva de uma educação para as mídias e analisa os principais enfoques dados às tendências das pesquisas e práticas educativas midiáticas. No texto é possível perceber a necessidade do exercício da crítica à vida em sociedade, seus interesses e a necessidade do convívio social-cultural na busca pela construção do conhecimento que emancipe a todos e todas.
\end{abstract} Palavras-chave: Educação. Mídia. Comunicação. Informática Educativa.

Cadernos de Pós-graduação, São Paulo, v. 17, n. 2, p. 183-196, jul./dez. 2018. 
Abstract: This paper presents a theoretical and conceptual study for the communication path of the composition in education, bringing together the concepts of culture, media and human communication. The topics of study are based mainly in Williams (1969), Adorno (1970), Thompson (1979), Benjamin (1986), Martin-Barbero (1987) and Bauman (1975; 2012). The article aims to link the history of communication and media education, in particular the important educational computing in the processes of teaching and learning in the contemporary. The methodology of qualitative and used from the literature focusing on the perspective of education for the media and analyzes the main approaches to data trends of research and media education practices. In the text you can see the need for the exercise of criticism of life in society, their interests and the need for social and cultural interaction in the search for knowledge building that emancipate all and all.

Key words: Education media. Communication. Educational Informatics.

\section{Introdução}

construção deste trabalho é resultado do estudo sobre a temática Edu-
cação, Comunicação e Mídias para se constituir como um objeto qualificado, observado à luz de diferentes autores. É por vias destas leituras que os autores deste artigo se instrumentalizam para apresentar sua compreensão, interpretação e análise.

Neste sentido, a problemática proposta e perseguida foi eleger autores para que se potencialize identificar a interconectividade que evade de seus trabalhos, sem que estes tivessem a intenção para tal. Constituir esta rede e identificar os nós interligados dos autores e seus conceitos, é tarefa que aqui se apresenta, fruto de um estudo abreviado e genuíno - portanto, longe de ser um exercício do narrador da experiência coletiva e de sabedoria (BENJAMIM, 1986).

Como ponto de partida para o desenvolvimento do artigo reúne-se um estudo sobre os trabalhos que originam a integração do campo educacional à comunicação e à cibercultura para avançar sobre o conceito de cultura e a integração das diferentes tecnologias a um projeto educacional.

\section{Conceito e ênfases nos estudos midiáticos}


$\mathrm{Na}$ pesquisa teórica sobre o conceito de mídias e educação (WEIDUSCHAT, 2002), podemos traçar um estudo que se concentra a partir da década de 80. O relatório da UNESCO de 1984 (in: BELLONI, 2001. p. 12) aponta para o momento em que afloravam as preocupações de uma educação para as mídias anter ${ }^{1}$ ior ao advento da informática/internet apresentando um conceito amplo:

A noção de educação para as mídias abrange todas as maneiras de estudar, de aprender e de ensinar em todos os níveis [...] e em todas as circunstâncias: a história, a criação, a utilização e avaliação das mídias enquanto artes plásticas e técnicas, bem como o lugar que elas ocupam na sociedade, seu impacto social, as implicações da comunicação mediatizada, a participação e a modificação do modo de percepção que elas engendram, o papel do trabalho criador e o acesso às mídias.

Educar para as mídias implica, neste sentido, em percebê-las além das práticas meramente instrumentais de manipulação, caracterizando o tecnicismo redutor e acrítico. Por outro lado, praticar uma educação para as mídias só é possível, como reconhece Belloni (2001, p. 13), através de um "salto qualitativo na formação de professores, uma mudança efetiva no sentido de superar o caráter redutor da tecnologia educacional, sem perder suas contribuições, para chegar à comunicação educacional".

Ao explorar, no entanto os estudos das mídias como campo da comunicação educacional, concentrou-se como etapa inicial o foco das mídias enquanto recursos da informática, em diferentes abordagens, dentre elas:

\subsection{A informática instrutiva/cognitiva}

Utilizar a informática para ensinar as crianças a pensar foi um trabalho desenvolvido por Seymour Papert (1994), quando desenvolveu uma linguagem de programa- 
ção - LOGO - que permitiria às crianças extrapolarem os até então conhecidos programas de exercício e prática. Com a linguagem LOGO Papert acreditava revolucionar o modo como as crianças aprendiam, conferindo-lhes a própria tarefa de programação. As crianças passariam a utilizar o computador "como uma ferramenta para trabalhar e pensar, como um meio para realizar projetos, uma fonte de conceitos para pensar novas ideias" (PAPERT, 1994. p. 168).

$\mathrm{Na}$ linguagem LOGO a criança utiliza uma tartaruga como ícone do cursor que se move pela tela oferecendo-lhe a possibilidade de criar diferentes figuras geométricas. Ao observar os movimentos da tartaruga, as crianças podem perceber se seu programa obteve o resultado esperado/programado. Caso contrário, ela mesma pode refazer os seus passos, percebendo sua própria linha de raciocínio e reconstruindo uma nova opção para a programação desejada. A grande inovação trazida por Papert se resumiria, genuinamente, na oportunidade dada às crianças de entenderem o modo como pensavam para resolver certos tipos de problemas. A ênfase sobre os estudos da linguagem LOGO se encerram na visão de que o computador, enquanto ferramenta de programação, possibilita o desenvolvimento cognitivo da criança.

\subsection{A informática interconectiva}

A possibilidade de conexão dos computadores da escola à internet, no final da década de 80, possibilita novos horizontes de acesso à informação. Não se trata somente de chegar até os conteúdos e jogos disponibilizados na rede, mas de eficazmente filtrá-los para determinados objetivos. A internet oferece uma nova tarefa aos seus “consumidores”, ampliada a noção de seu uso pelos alunos para além de meros receptores vindo a assumir a posição de autores. Neste sentido, as tecnologias exercem uma eufórica autonomia para os/as seus usuários, conferindo-lhes o papel criativo na utilização da ferramenta. 
Comunicar-se com diversas pessoas conectadas à rede, desenvolver pesquisas através de consulta aos textos e hipertextos disponíveis na internet, desenvolver uma página pessoal criando uma identidade dentro da rede são alguns dos projetos que se desenvolveram nas escolas. Alguns destes trabalhos são acompanhados sistematicamente através de pesquisa científica, como o Projeto Kidlink, coordenado no Brasil pela professora Marisa Lucena, que oferece espaço de discussão às crianças do mundo inteiro nas situações vivenciadas por elas em diferentes países.

O lugar que a internet vem ocupando na educação, quando orientado pelos/as professores/as, é caracterizado como uma estratégia de expressão democrática para os/as alunos/as. Manipular as tecnologias e as informações passa a ser uma competência que associa a habilidade técnica à crítica e reflexão. Esta competência é incansavelmente referida em eventos educacionais, buscando definir a importância das redes sociais.

\subsection{Informática virtual}

Nesta ênfase, as fronteiras que a tecnologia ultrapassa exprimem novas descobertas para a aprendizagem escolar por meio das experiências virtuais. Chegam na tentativa de alargar o campo cognitivo, oferecendo-nos a possibilidade de entramos em contato com sensações que evadem da realidade. Seus estudos apontam para a virtualidade como representação cognitiva de um modelo analógico. Neste caso, a representação de imagens não se baseia somente em cópias armazenadas mas criam novas mensagens icônicas.

O significado destas representações para a aprendizagem é pesquisado em seus impactos neurofisiológicos. Santaella e Nöth (1998. p. 32) afirmam que "pesquisas neurofisiológicas mostraram que imagens mentais ativam no cérebro os mesmos padrões de excitação neuronal (cótex visual) que a visão real e essas regiões do cérebro, ativadas 
no processo visual, são outras do que aquelas ativadas por conceitos abstratos". Neste âmbito, imagens mentais e imagens reais entram para o campo das ciências da cognição na qual a psicologia cognitiva procura definir a experiência do mundo virtual.

\subsection{Informática psicopedagógica}

Outro foco de estudo diz respeito às contribuições que a informática na educação podem oferecer para a aprendizagem escolar. Em pesquisa conduzida desde o final da década de 90 até 2009, pela professora Lea da Cruz Fagundes junto ao Laboratório de Estudos Cognitivos da UFRGS, são levantadas as possibilidades de se oportunizar um "ambiente de aprendizagem enriquecido com o computador" (OLIVEIRA, 2000, p. 27). A pesquisa é desenvolvida com crianças repetentes e que em sua maioria traziam histórias de vida marcadas por situações sociais trágicas. A pesquisa trata os problemas da aprendizagem - especialmente relacionados à matemática e à linguagem escrita - simultaneamente com a recuperação da auto-estima da criança. Como resultados da pesquisa, os alunos repetentes que passaram pelo ambiente de aprendizagem proposto foram, ao final do ano letivo, todos aprovados. A pesquisa é ainda direcionada para a educação especial, a inclusão digital e social.

Noções de percepção e desenvolvimento motor, atividades relacionadas à realidade virtual, simulando situações que provoquem algumas sensações, dentre outros, vem sendo estudados com ênfase especial pela UNICAMP, USP e UFRGS através de núcleos de Informática Educativa. Novas pesquisas também são citados estudos que observam a produção de formas de interatividade e sociabilidade, termo este cunhado em 1997 (GUIMARÃES JÚNIOR, 1997) e ainda se centrando no plano psico-afetivo e social (VALENTE; MARTINS; BARANAUSKAS, 2012) que culminam na relação educação, sociedade e tecnologia de forma integrada às demandas da sociedade. 
A partir destas abordagens históricas da utilização das mídias na educação reúne-se uma visão correlata que parte do conceito de cultura diante da educação e comunicação.

\section{Cultura, aprendizagem e mídias: integração e coesão}

No processo de construção da identidade individual e coletiva está em jogo o papel da "aprendizagem humana como produto da evolução" (TOMASELLO, 2003, p. 296). Concebe-se a aprendizagem como resultado da linguagem e das relações sócioculturais que são estabelecidas entre os sujeitos que criam condições para que as pessoas interajam intersubjetivamente e adotem convenções comunicativas. Nesta interação social, cremos haver uma nova forma de representação cognitiva que não somente oferece a capacidade para acumular conhecimentos, mas também, capacidade de entendêlos, de estabelecer juízos individuais, tomar decisões, fazer categorizações, analogias e avaliações.

Sobre a tendência da comunicação de moldar a cultura humana, Postman (apud CASTELLS, 1999, p. 354) defende que “nós não vemos a realidade como 'ela' é, mas como são nossas linguagens. E nossas linguagens são nossas mídias. Nossas mídias são nossas metáforas. Nossas metáforas criam o conteúdo de nossa cultura". Na interpretação de Castells, a mídia representa o tecido simbólico de nossa vida, e ela

[...] tende a afetar o consciente e o comportamento assim como a experiência real afeta os sonhos, fornecendo a matéria-prima para o funcionamento de nosso cérebro. É como se o mundo dos sonhos visuais (informação/entretenimento) devolvesse ao nosso consciente o poder de selecionar, recombinar e interpretar as imagens e os sons gerados mediante nossas práticas coletivas ou preferências individuais. É um sistema de feedbacks entre espelhos deformadores: a mídia é a expressão de nossa cultura, e nossa cultura funciona principalmente por intermédio dos materiais propiciados pela mídia. (2000, p. 361-362)

Cadernos de Pós-graduação, São Paulo, v. 17, n. 2, p. 183-196, jul./dez. 2018. 
A sociedade informacional, enfim, privilegia aos que dominam o tratamento da informação. A escola é propulsora e ascendente junto à democratização do acesso da comunidade escolar às tecnologias informacionais, não somente como consumo, mas também como produção/presença individual, como por exemplo, na criação de páginas de internet ou em redes sociais. Neste cenário, embora a escola passe a ter capacidade, vez e voz na criação de conteúdos e formas de interatividade, de um lado, passa também a perder-se diante da imensidão de informações que circula, diluindo-se diante da formação de seus alunos, por outro.

Neste sentido, projetos educacionais permitem oportunizam que os alunos e alunas desenvolvam habilidades de seleção e processamento da informação, a autonomia, a capacidade de tomada de decisões, o trabalho em grupo, a polivalência, a flexibilidade, imprescindíveis nos diferentes contextos sociais, como mercado de trabalho, vida social, que se constituem como o movimento cultural.

A partir daí, inicia-se com o levante do conceito de cultura e as mudanças que este conceito sofreu. Em um primeiro momento, pode-se acompanhar a ampliação da sua mera correspondência ao termo "civilização", como sociedade ordenada e educada, em oposição à barbárie. Williams (1969) segue um conceito teórico do materialismo cultural, priorizando a produção cultural e literária material, o conhecimento erudito, o desenvolvimento e progressos sociais localizados em um contexto histórico específico.

Thompson (1995) por sua vez, traz à tona o mundo real, no constante envolvimento das pessoas com suas vidas vividas, caracterizado como uma troca contínua de ações, interações e interpretações constitutivas da caminhada pessoal e social. A vida social, a história da humanidade, as relações estabelecidas entre os indivíduos, dentre outros, concentra as formas simbólicas e sua relação com os contextos sociais que, segundo Thompson (1995 p. 18) estão ora "para estabelecer e sustentar relações de 
dominação nos contextos sociais em que elas são produzidas, transmitidas e recebidas", ora para levar o indivíduo a olhar para um "contexto radical, subversivo, contestador" destas mesmas relações. Cultura, neste sentido, constitui-se como um movimento da realidade vivida, da experiência, da identidade dos grupos sociais.

Bauman, por sua vez, realiza um amplo percurso diante do conceito de cultura. Publica, em 1975, uma primeira versão de seu trabalho 'Ensaios Sobre o Conceito de Cultura’ e realiza, em 2012, uma revisão crítica deste seu próprio trabalho à luz das ciências sociais, desde os gregos antigos até os pós-estruturalistas. Foca, no entanto, nas correntes de pensamento que estudaram o significado da cultura na sociedade. E amplia, neste sentido, o conceito de cultura implícito no discurso científico para um conceito ambivalente: a cultura como práxis, entendida como atividade livre, universal, criativa e autocriativa pela qual os homens transformam o mundo em que vivem.

Permite-se observar, a partir desta conceituação da cultura, o esforço de alocar os indivíduos e os grupos na história, na realidade em que vivem, constituindo a cultura como uma construção, um modus faciendi. Benjamim (1986) nos lembra como as transformações decorridas da Revolução Industrial criam novas formas de ser e estar no mundo: ora substituindo, ora criando um novo homem, novas técnicas, novas leituras da arte, da fotografia, do narrador. Tais mudanças, para Adorno por sua vez, devem ser intencionais, sob a bandeira de instituir uma educação contra a barbárie, desvencilhando o sujeito da manipulação da opinião pública produzida pelas mídias. Para o autor "a única concretização efetiva da emancipação consiste em que aquelas poucas pessoas interessadas nesta direção orientem toda a sua energia para que a educação seja uma educação para a contestação e para a resistência” (ADORNO, 1970, p.12).

Neste embate, Jesús Martín-Barbero (1987) desloca o conceito de mídia, presente na teoria crítica da Escola frankfurtiana predominante na década de sessenta e 
setenta enquanto instrumento de manipulação da sociedade e como produtora da "Indústria Cultural" - agenciadora da alienação e fomentadora de arte e entretenimento cultural colocado a serviço do fascismo. A mídia, observada na América Latina, portanto deslocada do contexto europeu, está para Martín-Barbero como a invenção do popular e do massivo, sendo propulsora de interrelações sociais. O autor identifica a possibilidade de evasão do trabalho do cinema e televisão como manipuladores midiáticos para tornar-se crescente o vínculo das tradições e das expressões da cultura popular, presentes na literatura de cordel, na viola caipira, no "rádio-teatro". Neste sentido, um novo tom é trazido ao conceito de mídia:

Em vez de fazer a pesquisa partir da análise das lógicas de produção e recepção, para depois procurar suas relações de imbricação ou enfrentamento, propomos partir das mediações, isto é, dos lugares dos quais provêm as construções que delimitam e configuram a materialidade social e a expressividade cultural [...]. (MARTÍN-BARBERO, 1987, p. 304 - tradução nossa).

Neste ponto, Martín-Barbero coincide com Benjamin, considerando que o popular na cultura resulta da experiência e produção. A realidade é tomada como algo descontínua, histórica e propulsora da transformação nas condições de produção e de mudanças da cultura. Por conseguinte, a cultura de massa constitui a própria mídia, na percepção e no seu uso, acima de seu produto e obra.

Portanto, o trabalho educacional, partimos dos estudos de Bauman (2012), que realiza um amplo percurso diante do conceito de cultura, desde os gregos antigos até os pós-estruturalistas. Necessário se faz focar no significado da cultura na sociedade para um conceito ambivalente: a cultura como práxis, entendida como atividade livre, universal, criativa e autocriativa pela qual os homens transformam o mundo em que vivem.

Permite-se observar, a partir desta conceituação da cultura, o esforço de alocar os indivíduos e os grupos na história e na realidade em que vivem, diante de uma cultura 
em construção, uma cultura do modus faciendi. Converge para esta análise MartínBarbero (1997) quando desloca o conceito de mídia presente na teoria crítica da Escola frankfurtiana predominante no período de 1960 até 1980. O autor observada a mídia no contexto da América Latina, portanto deslocada do contexto europeu. Assim, a invenção do popular e do massivo é propulsor de interações sociais. O autor identifica a possibilidade de evasão do trabalho do cinema e televisão como manipuladores midiáticos para tornar-se crescente o vínculo das tradições e das expressões da cultura popular, presentes na literatura de cordel, na viola caipira, no "rádio-teatro". Neste sentido, um novo tom é trazido ao conceito de mídia:

Em vez de fazer a pesquisa partir da análise das lógicas de produção e recepção, para depois procurar suas relações de imbricação ou enfrentamento, propomos partir das mediações, isto é, dos lugares dos quais provêm as construções que delimitam e configuram a materialidade social e a expressividade cultural [...]. (MARTÍN-BARBERO, 1997, p. 304 - tradução nossa).

Considera-se que o popular na cultura resulta da experiência e produção. Nesta ótica, a realidade é tomada como descontínua, histórica e propulsora da transformação nas condições de produção e de mudanças. O humano contemporâneo, em sua aprendizagem ao longo da vida constitui a própria mídia, na percepção e no seu uso, acima de seu produto e obra: desvelando as competências essenciais, pessoais e sociais.

\section{Considerações finais}

Ao mirar para o futuro nestes tempos do cibercultura, há que ter em vista de que não cabe o domínio tecnológico, simplesmente. Há que se representar a habilidade e capacidade de produzir conhecimentos, o que pode, por vezes, aumentar a exclusão dos grupos marginalizados sem acesso à esfera tecnológica. Resta-nos, por conseguinte, 
entender as chances futuras como uma possibilidade de reinventar a identidade do ser e da sociedade, norteando-a pelo interesse em torno do convívio social/cultural.

A partir deste entendimento, a formação escolar humana permite experimentar na escola a própria construção de identidades de uma sociedade centrada em interesses. A linguagem midiática, ou a informatizada, transpõe estereótipos e reprodução dos valores monoculturais. Traz propostas de ruptura, é dada a voz para a contestação através de um novo projeto para esta mídia, em que se constitui o sujeito como ator das interações sociais, dos jogos ou das pesquisas conduzidas no espaço escolar.

Exemplificando, das reflexões sobre as ações e das ações nascidas a partir das reflexões que se constroem com e pelas crianças junto a projetos educacionais midiáticos, podemos citar: a produção de propostas para mudanças no enredo de jogos, valorizando as experiências das próprias crianças; a produção de jornal por grupos de alunos e alunas que, por um lado, confirmam a reprodução das relações de poder que se exerce na linguagem jornalística, mas, por outro lado, permite romper com práticas ideológicas, compondo uma nova voz ao jornal, voltado para a luta das pessoas simples e excluídas socialmente; a iniciação no exercício da crítica que permita aos sujeitos perceber as trocas sociais desiguais que são vividas, como nas estereotipias em torno da vida em sociedade, apresentada de forma infantilizada no enredo/conteúdos das mídias.

Enfim, nesta interação dos alunos e alunas, media-se a aprendizagem dos sujeitos entre si, reinventando-se a história que se construiu para eles e reinventando-se os próprios temas e tecnologias que acompanham as mídias junto ao espaço escolar, bem como melhorando ou atualizando os processos do ensino e da aprendizagem. Importa, neste caso, que o ato de ensinar não é meramente um ato de transmitir conhecimentos, mas de construí-lo ou produzi-lo, como ensina Freire (2000), buscando, em cada um de nós, sujeito, escola, sociedade, o espaço de identidade em torno de nossos achados. 


\section{Referências}

ADORNO, Theodor. Educação e emancipação. São Paulo: Paz e Terra, 1970.

BAUMAN, Zygmunt. Ensaios sobre o conceito de cultura. Rio de Janeiro: Zahar, 2012.

BENJAMIN, Walter. Magia e técnica, arte e politica. São Paulo: Brasiliense, 1986.

BELLONI, Maria Luiza. O que é mídia-educação. Campinas: Autores Associados, 2001.

CASTELLS, Manuel. A sociedade em rede: a era da informação: economia, sociedade e cultura. 4. ed. São Paulo: Paz e Terra, 1999. 617 p.

FREIRE, Paulo. Pedagogia da indignação: cartas pedagógicas e outros escritos. São Paulo: Unesp, 2000. Disponível em: Http://plataforma.redesan.ufrgs.br/biblioteca/pdf_bib.php?COD_ARQUIVO=17339

Acesso em: 25. OUT. 2018.

GUIMARÃES JÚNIOR, Mário José Lopes. A cibercultura e o surgimento de novas formas de sociabilidade. Piriápolis, Uruguai, 1997.

MARTÍN-BARBERO, Jesús. De los medios a las mediaciones. Barcelona: Gustavo Gili, 1987. (e-book). Disponível em: http://incom.uab.cat/download/eBook_incomuab_14.pdf Acesso em: 25. OUT. 2018.

OLIVEIRA, Vera Barros de Oliveira (Org). Informática em psicopedagogia. 2. ed. São Paulo: Senac, 2000.

PAPERT, Seymour. A máquina das crianças: repensando a escola na era da informática. Porto Alegre: Artmed, 1994.

SANTAELLA, Lucia; NÖTH, Winfried. Imagem: cognição, semiótica, mídia. São Paulo: Iluminuras, 1998.

TOMASELLO, M. Origens culturais da aquisição do conhecimento bumano. (C. Berliner, Trad.) São Paulo: Martins Fontes. (Trabalho original publicado em 1999). 2003.

THOMPSON, J. B. Ideologia e cultura moderna. Petrópolis (RJ): Vozes, 1995. 
VALENTE, J. A.; MARTINS, M. C.; BARANAUSKAS, M. C. C. Laptop educacional e a educação baseada na investigação: do estudar fatos científicos para o fazer Ciência. Projeto um computador por aluno: pesquisas e perspectivas. Rio de Janeiro: NCE/UFRJ, 2012.

WILLIAMS, R. Cultura e sociedade. São Paulo: Nacional, 1969.

WEIDUSCHAT, I. Informática educativa: uma revisão teórica. Leonardo (Oxford), Indaial/SC, v. 1, n. 4, p. 19-23, 2002.

recebido em 28 mar. 2018 / aprovado em 24 ago. 2018

\section{Para referenciar este texto:}

CAMARGO, D. B.; WEIDUSCHAT, I.; NORILER, A. Educação, comunicação e mídia: uma abordagem teórica. Cadernos de Pós-graduação, São Paulo, v. 17, n.2, p. 183-196, jul./dez. 2018. Disponível em: <https://doi.org/10.5585/cpg.v17n2.8514>. 


\title{
PolítiCAS DE EDUCAÇÃo ESPECIAL: ANÁlISE dO PLANO DE EDUCA- ÇÃO (2015 - 2025) E DIRETRIZES DA EDUCAÇÃO ESPECIAL (2012) DE MACAPÁ-AP
}

\author{
SPECIAL EDUCATION POLICIES: ANALYSIS OF THE EDUCATION \\ PLAN AND GUIDELINES FOR MACAPÁ-AP SPECIAL EDUCATION
}

Marcia Maria dos Santos Mestranda pelo Programa de Pós-Graduação em Educação pela Universidade Federal do Amapá. Amapá - AP - Brasil marcia_m_santos@hotmail.com

\section{Maria do Carmo Lobato da Silva}

Doutoranda em Educação Especial pelo Programa de Pós-Graduação em Educação Especial na Universidade Federal de São Carlos. Docente da Universidade Federal do Amapá. Amapá - AP - Brasil carmo.lobato@yahoo.com.br

Ilma de Andrade Barleta Doutora em Educação pela Universidade Federal do Pará. Docente da Universidade Federal do Amapá. Amapá - AP - Brasil ilmabarleta@bol.com.br

Resumo: Este artigo analisa a concepção de educação inclusiva a partir das metas para Educação Especial no Plano Municipal de Educação (2015-2025) e nas Diretrizes para a Educação Especial (2012) implementados em Macapá, com foco principal na análise dos compromissos assumidos para o gerenciamento das ações em torno da educação dos alunos com deficiência intelectual. O estudo se configurou como pesquisa documental, de abordagem qualitativa à luz do materialismo histórico, que considera o processo dos fenômenos estudados e como eles se

Cadernos de Pós-graduação, São Paulo, v. 17, n. 2, p. 197-221, jul./dez. 2018. 
constituem na concretude das políticas educacionais neoliberais. Para tanto, fez-se uso da análise do discurso, pautada na concepção de Bakhtin (2006) e Fairclough (2001). A metodologia baseou-se na análise dos documentos: 1) Plano Municipal de Educação (2015-2025) com ênfase nas metas para educação especial; 2) Diretrizes para Educação Especial (2012), a fim de captar até que ponto os discursos apresentados, refletem o processo de inclusão dos alunos com deficiência intelectual no Município de Macapá. Os resultados indicaram uma educação que está distante de se efetivar de forma plena, tanto pela incompreensão de suas concepções e fundamentos, quanto pela escassez de recursos para a manutenção da Educação Especial. Portanto, o discurso dos documentos sinaliza que a política de inclusão das pessoas com deficiência, em caráter local, segue os preceitos da política geral consubstanciada no modelo neoliberal com enfoque clínico conservador da deficiência.

Palavras-chave: Alunos com deficiência intelectual. Concepção de deficiência. Política municipal de educação especial.

\begin{abstract}
This article analyzes the conception of inclusive education from the goals for Special Education in the Municipal Education Plan (2015-2025) and in the Guidelines for Special Education (2012) implemented in Macapá, focusing on the analysis of the commitments assumed for the management of actions around the education of students with intellectual disabilities. The study was configured as a documentary research with a qualitative approach under the light of historical materialism, that considers the process of the studied phenomena and how they constitute the concreteness of neoliberal educational policies. For this purpose, it was used the speech analysis based on Bakhtin (2006) and Fairclough (2016) ideas. The methodology was analyzed the documents: 1) Municipal Education Plan (2015-2025), with emphasis on the goals for special education; 2) Guidelines for Special Education (2012), to capture whither the speeches presented reflects the process of inclusion of students with intellectual disabilities in Macapá. The results indicated an inclusive education far from being fully effective, due to the lack of understanding of its conceptions and foundations, as well as the scarcity of resources to the maintenance of Special Education. Therefore, the discourse of the documents indicates that the inclusion policy of people with disabilities, in a local character, follow the precepts of general policy embodied in the neoliberal model with a conservative clinical approach to disability.
\end{abstract}

Keywords: Students with intellectual disabilities. Deficiency conception. Special education policy.

Cadernos de Pós-graduação, São Paulo, v. 17, n. 2, p. 197-221, jul./dez. 2018. 


\section{Introdução}

$$
\begin{aligned}
& \text { educação de pessoas com deficiência intelectual, na atual conjuntura, } \\
& \text { está consubstanciada por concepções e determinações de políticas ofici- }
\end{aligned}
$$
ais de Educação Especial e Inclusiva. Tais políticas se materializam por meio de discursos efetivados nas Legislações, Decretos, Diretrizes e Planos Educacionais de Governos: Federal, Estadual ou Municipal (KASSAR, 2011). Esta pesquisa propõe reflexões sobre a concepção de projetos em disputa de educação inclusiva a partir da análise das metas para a educação especial do Plano Municipal de Educação (2015-2025) e das Diretrizes para a Educação Especial (2012) implementadas no Município de Macapá, tomando como foco principal a análise dos compromissos assumidos para o gerenciamento das ações em torno da educação dos alunos com deficiência intelectual.

Trinta anos depois da criação da Constituição Federal de 1988 que incorporou inúmeros direitos aos cidadãos, fruto de lutas populares e disputas de projetos sociais e educacionais, dentre eles, a garantida obrigatoriedade do direito à educação para pessoas com deficiência (BRASIL, 1988), o acesso ao Ensino Regular se tornou o slogan principal das políticas na perspectiva inclusiva. O discurso assegurava que as crianças com deficiência estavam ingressando na escola na idade certa e inseridas numa classe regular com apoio do Atendimento Educacional Especializado (AEE), ofertado na maioria das escolas municipais. O serviço do AEE é reafirmado com a política da Educação Especial na Perspectiva Inclusiva, que o pontua como direito ao acesso desde a educação Infantil, perpassando os demais níveis de ensino (BRASIL, 2010).

Ocorre que, apenas a garantia do acesso físico não provoca rupturas nos espaços escolares, pois dentro de um projeto de inclusão que compreende uma educação com qualidade, igualdade de condições de acesso, acessibilidade e permanência é fundamental que sejam atendidas todas as necessidades dos alunos. Não obstante a isso, a 
Políticas dE EDUCAÇÃo ESPECIAL: ANÁLISE DO PLANO DE EDUCAÇÃo (2015 - 2025) E DIRETRIZES DA EDUCAÇÃO ESPECIAL (2012) DE MACAPÁ-AP

história da educação especial, segundo Kassar (2009), aponta vários exemplos de descasos com a população brasileira e os momentos de avanços legais nesse campo foram também guiados pela lógica econômica, do mercado e do lucro.

Muitos docentes, pais e estudiosos da área da Educação Especial estão engajados na luta por melhores condições de ensino e aprendizagem, com perspectivas para a concretude dos discursos contidos nas políticas educacionais. Para Kassar, de Oliveira e da Silva (2007) não se deve tratar o processo de inclusão de forma abstrata, nem negligenciar seu papel como espaço privilegiado de acesso ao saber. Pois é desta forma que as políticas estão sendo gestadas e implementadas em todo país.

Por isso, os estudos a cerca da temática sobre as políticas educacionais voltados para a Educação Especial têm sido cada vez mais explorados, com o intuito de compreender como é instituída a inclusão dos alunos em diferentes níveis de ensino. Sendo assim, é preciso ter a clareza que esse processo envolve a entrada na escola, a permanência e a aprendizagem com qualidade.

Desta forma, a pesquisa foi realizada com intuito de analisar os discursos veiculados no Plano Municipal de Educação (2015-2025) e das Diretrizes para a Educação Especial (2012) que norteiam as políticas educacionais do município de Macapá/AP. Caracterizando-se como documental, de abordagem qualitativa à luz do materialismo histórico, apoiada na análise do discurso.

Nos procedimentos metodológicos foram feitos recortes dos documentos, com foco na análise da meta 4 do Plano Municipal de Educação (2015-2025), que compreende o conceito e concepção da Educação Especial e restringindo-se as estratégias 4.1, que trata da contabilização das matriculas de estudantes da rede pública que recebem o atendimento educacional especializado (AEE) de forma complementar ou suplementar; a estratégia 4.3 trata da implementação e manutenção das Salas de Recursos Multifuncionais (SRM) em parceria com o Governo Federal; e, para finalizar, a estratégia 
4.26 que trata do quantitativo de alunos com deficiência em sala de aula. Já nas Diretrizes municipais para a Educação Especial (2012), buscou-se compreender a concepção de educação e inclusão voltada para os alunos com deficiência intelectual, em que conceitos e características se fundamentam.

Para Shiroma, Campos e Garcia (2005), compreender e intervir criticamente nos processos de inclusão escolar dos alunos com deficiência, à luz das políticas públicas, faz-se necessário investigar como a ideologia, a lógica e a racionalidade que apoiam os textos das políticas educacionais, dentro de um contexto de reformas articulam-se com os interesses, valores, perspectivas dos sujeitos que utilizam e realizam as mudanças sociais a partir das políticas em curso. Para as autoras, neste contexto de reforma educacional é importante perceber:

Quais os caminhos trilhados na busca de legitimação das reformas? Se entendermos discurso como expressão e diretriz de práticas sociais, indagamos: como seriam eles capazes de transformar as práticas que ocorrem nas instituições educacionais? Como chegam a alterar a cultura das organizações escolares, as práticas e relações sociais que se travam em seu interior? E como poderemos construir novas lentes para interpretar os textos da reforma, compreender e intervir criticamente nos rumos desta política? (SHIROMA; CAMPOS; GARCIA, 2005. p. 430).

Neste sentido há uma preocupação em considerar o processo dos fenômenos estudados e como ele se constitui. É na tentativa de estudar as políticas educacionais para a educação especial que se tenta analisar a concretude dos pressupostos e determinações contidos nos registros de documentos oficiais para as pessoas com deficiência. Corrêa e Kassar (2009) analisam este fenômeno como parte de uma totalidade, acreditando ser necessária a compreensão da concepção de movimento contraditório inerente à própria história.

Sendo assim, a gestão da Educação Especial na esfera municipal vem se configurando como processo de descentralização que desde a Constituição Federal de 1988 
Políticas de EDUCAÇÃo ESPECIAL: ANÁLISE DO PLANO DE EDUCAÇão (2015 - 2025) E DIRETRIZES DA EDUCAÇÃO ESPECIAL (2012) DE MACAPÁ-AP

possibilitou aos municípios maior autonomia relativa na formulação de políticas educacionais, principalmente para o Ensino Infantil e Fundamental (SOUZA; FARIA, 2004). Com isso, é perceptível atos puramente contraditórios, quando delega ao município poderes que muitas vezes não consegue cumprir devido à injusta divisão de responsabilidades provocada pelo Governo Federal, no sentido de centralizar os recursos e atribuir o mínimo aos municípios da federação.

\section{$2 \mathrm{O}$ processo de municipalização no contexto das políticas de educação especial}

$\mathrm{Na}$ atual conjuntura política, econômica, administrativa e social os processos de reforma apontam para a descentralização da educação pela via da municipalização e se efetiva a partir de um longo período de regime autoritário ao qual predominou políticas de desinvestimentos da Educação Básica (SOUZA, FARIA, 2004).

Este cenário se configura em processos históricos que marcam a trajetória da educação no Brasil, modificando as formas de administrar o Estado no sentido de descentralizar as estruturas gerenciais na esfera pública. Neste viés, Corrêa e Kassar (2009) colaboram na caracterização deste processo:

O Brasil da década de 1980 foi marcado por um processo de redemocratização, após 20 anos de ditadura militar. Esse período é o contexto das lutas travadas na elaboração da Constituição Federal de 1988, que produz um novo estatuto jurídico para o país. Pode-se afirmar que, contando com o envolvimento da sociedade civil organizada, essa Constituição caracteriza-se por uma ênfase nos direitos sociais. (CORRÊA; KASSAR, 2009, p. 02).

Com isso, a educação das pessoas com deficiência agrega-se a este contexto, também resultante das lutas de pais, educadores e os próprios atores mencionados nas políticas que determinam seu desenvolvimento educacional. Não se pode negar a ênfase 
dada aos direitos sociais na Constituição Federal de 1988, que sob a lógica de desenvolvimento do Estado coloca no bojo de suas políticas a educação como “direito público e subjetivo" (BRASIL, 1988, art. 208).

Neste sentido, o processo de municipalização ganha força a partir da criação da União Nacional dos Dirigentes de Educação, (UNDIME) em 1986, que mesmo sem ter este objetivo começa a se posicionar a favor de uma maior participação do município nos processos educacionais, exigindo descentralização nas ações do poder público (CORRÊEA; KASSAR, 2009).

Sendo assim, em se tratando do que consta na Constituição Federal de 1988 no seu Artigo 211, elencado o regime de colaboração entre a União, Estados, Municípios e o Distrito Federal, hoje em consonância com as emendas n ${ }^{\circ} 14 / 1996, n^{\circ} 53 / 2006$ e $\mathrm{n}^{\mathrm{o}} 59 / 2009$ que determina:

211- \ $1^{\circ}$ A União organizará o sistema federal de ensino e o dos Territórios, financiará as instituições de ensino públicas federais e exercerá, em matéria educacional, função redistributiva e supletiva, de forma a garantir equalização de oportunidades educacionais e padrão mínimo de qualidade do ensino mediante assistência técnica e financeira aos Estados, ao Distrito Federal e aos Municípios; (Redação dada pela Emenda Constitucional no 14, de 1996).

$\S 2^{\circ}$ Os Municípios atuarão prioritariamente no ensino fundamental e na educação infantil. (Redação dada pela Emenda Constitucional $\mathrm{n}^{\mathrm{o}}$ 14, de 1996).

$\S 3^{\circ}$ Os Estados e o Distrito Federal atuarão prioritariamente no ensino fundamental e médio. (Incluído pela Emenda Constitucional ${ }^{\circ}$ 14, de 1996).

$\int 4^{\circ} \mathrm{Na}$ organização de seus sistemas de ensino, os Estados e os Municípios definirão formas de colaboração, de modo a assegurar a universalização do ensino obrigatório. (Incluído pela Emenda Constitucional $\mathrm{n}^{\circ} 14$, de 1996).

$\int 4^{\circ} \mathrm{Na}$ organização de seus sistemas de ensino, a União, os Estados, o Distrito Federal e os Municípios definirão formas de colaboração, de modo a assegurar a universalização do ensino obrigatório. (Redação dada pela Emenda Constitucional n 59, de 2009). 
Políticas de EDUCAÇão especial: ANÁlise do PLANO DE EDUCAÇÃo (2015 - 2025) E DIRETRIZES DA EDUCAÇÃO ESPECIAL (2012) DE MACAPÁ-AP

$\int 5^{\circ} \mathrm{A}$ educação básica pública atenderá prioritariamente ao ensino regular. (Incluído pela Emenda Constitucional $n^{\circ}$ 53, de 2006). (BRASIL, 1988).

É importante destacar que é a partir do artigo 211 da Constituição Federal de 1988 que realmente se efetiva a organização dos sistemas de ensino pelo então chamado regime de colaboração. Porém, com o passar dos anos este documento passa a se fragmentar em várias Emendas Constitucionais (EC), como é o caso da EC no 14/1996, da EC no 53/2006 e da EC n 59/2009 que vão dar nova redação ao artigo da CF/1988 (SOUZA; FARIA, 2004).

Desta forma, a partir do conhecimento, reconhecimento e compreensão dos textos das legislações que legitimam as políticas educacionais, percebe-se necessidade de aprender decifrar os textos para poder compreender as políticas. No caso acima (art. 211), as EC assumem um papel de camuflar o verdadeiro sentido em suas narrativas. Como exemplo, pode-se citar a EC no 14/ 1996 da Constituição Federal, no seu Art. $1^{\circ}$ acrescenta no inciso VII do Art. 34 a alínea "e” dizendo que: "aplicação do mínimo exigida da receita resultante dos impostos Estaduais compreendida a proveniente de transferência, na manutenção e desenvolvimento do ensino” (BRASIL, 1996).

Outra EC que merece análise é a de no 59/2009 da CF que acrescenta ao art.76 do ato das disposições constitucionais transitórias o inciso $3^{\circ}$ constando que se deve reduzir anualmente, a partir de 2009, o percentual da desvinculação das Receitas da União incidentes sobre os recursos destinados à manutenção e desenvolvimento do ensino de que trata o art. 212 da CF/1988. Torna obrigatório o ensino na faixa etária de quatro a dezessete anos e amplia a abrangência dos programas suplementares para todas as etapas da Educação Básica e dá outras providências (BRASIL, 2009).

Cabe aqui, segundo Souza e Faria (2004) evidenciar que os municípios assumem as políticas que gerenciam a educação básica que antes apontavam para decisões compartilhadas entre os sistemas de ensino iguais e autônomos entre os entes federados, 
agora rompe com os anseios da sociedade civil de uma educação de qualidade e inclusiva para todos a partir das emendas constitucionais que desqualificam o teor dos artigos constitucionais.

Sendo assim, cabe o questionamento se realmente o município tem condições econômicas, políticas e sociais de cumprir com os compromissos assumidos nas ações dos Planos e Diretrizes municipais no que diz respeito aos alunos com deficiência intelectual. Considerando que os mesmos, assim como qualquer aluno em processo de aprendizagem, necessitam de acesso não somente aos espaços escolares, mas também de todo um aparato pedagógico e estrutural que favoreça o seu desenvolvimento de forma plena.

Por mais que, no âmbito das políticas educacionais de caráter inclusivo ancoradas em marcos legais que proclamam uma educação de qualidade, como é o caso do Movimento de Educação para Todos com as conferências ocorridas a partir dos anos 1990: Conferencia Mundial de Educação para Todos, ocorrida em Jontien, na Tailândia em 1990, aprovada por representantes de mais de cem países e Organizações Não Governamentais (ONG’s), cujo propósito foi aumentar a oferta da Educação Básica para a população mundial no prazo de 10 anos, seus princípios evidenciaram que este nível de ensino seria satisfatório às necessidades básicas da aprendizagem (RABELO; JIMENEZ; SEGUNDO, 2015).

Continuamente a Conferência de Nova Delhi (1993); a Declaração de Salamanca (1994); Dakar (2000); Constituição Federal de 1988; a Lei de Diretrizes e Bases da Educação Nacional (LDBEN 9394/1996), entre outros que carregam em seus escritos, perspectivas de universalizar o saber, priorizar a qualidade no ensino para a população excluída, sob a prospecção de incluir a todos na escola, inclusive as pessoas com deficiência intelectual. É importante pontuar que esta Educação não pode ser analisada isoladamente dos contextos social, político-ideológico e econômico, partindo do 
Políticas dE EDUCAÇÃo ESPECIAL: ANÁLISE DO PLANO DE EDUCAÇÃo (2015 - 2025) E DIRETRIZES DA EDUCAÇÃO ESPECIAL (2012) DE MACAPÁ-AP

princípio que a educação das pessoas com deficiência, também está fortemente marcada pelos interesses hegemônicos do capital (SILVA; OLIVEIRA, 2015).

O discurso destas políticas, segundo Rabelo, Jimenez e Segundo (2015) carrega a promoção de conferências com instrumentos nacionais e internacionais, que se configuram como marco estratégico no sentido de proclamar um novo papel que a Educação Básica deve desempenhar: "provocar a sustentabilidade dos países envolvidos com a agenda neoliberal" (RABELO; JIMENEZ; SEGUNDO, 2015, p. 14). Assim, a partir da proposição de que com o mínimo se faz mais se vêm implantando as políticas de inclusão no município.

Desta forma, faz-se necessário evidenciar o papel do Estado na atual conjuntura neoliberal e seu descompromisso com a escolarização das crianças com deficiência, onde a ação educativa assim como outros direitos sociais, passa a ser considerada como "serviço" que pode ser prestado pelos setores privados da sociedade por meio de um contrato de gestão estabelecido com o Estado. O município como ente federado também segue a mesma regra, no sentido de estabelecer parcerias entre o público e o privado.

O espaço do público se perde para o privado quando o Estado se retira da responsabilidade do seu compromisso com o financiamento do sistema educacional, seja ele regular ou especial. Com esse propósito, nos estudos de Borowsky (2013), Januzzi (2006), Garcia (2004), Peroni (2009), Farenzena e Machado (2006) e Gil et al (2010) sustentam as discussões que vêm sendo realizadas no âmbito do sistema de ensino público e o privado na Educação Especial, apontando que nesta trajetória o setor privado se sobrepõe ao público. Um exemplo claro disso se remete aos casos de alunos com sérios comprometimentos de natureza neurológica (mental ou intelectual) ou aqueles que não se enquadram na atual política de Educação Inclusiva, aqueles que a escola regular não consegue atender estão em escolas especiais na rede privada, com 
um percentual de matrículas de 65\% no período de 2007 a 2010 em instituições privadas. Sendo estas, mantidas com recursos do setor público, fortalecendo o sistema de parcerias (BOROWSKY, 2013).

\section{Resultados e discussão}

O Plano de Educação Municipal de Macapá, instituído pela Lei n 2.178/2015, aprovado para o decênio de 2015 a 2025, constituiu-se de 20 metas. Para este estudo, fez-se um recorte da meta 4.0 e dentre as trinta e uma estratégias destinadas à Educação Especial com propósito de serem efetivadas num período de dez anos, focou-se em apenas três (4.1; 4.3 e 4.26) no sentido de analisar a concretude das determinações contidas no documento tendo como direcionamento os alunos com deficiência intelectual.

Nestas estratégias, há que se contabilizar e enfatizar os vocábulos com maior predominância: "promover e garantir" (MACAPÁ, 2015, p.12-16). Tais vocábulos, de acordo os estudos sobre Educação Especial na atualidade se tornam imperativos, no sentido de apenas compor os textos das políticas públicas, que no caso aqui são os Planos e Diretrizes Municipais para a Educação Especial. Logo, a concretude de seus objetivos está fora da compreensão de serem alcançados. Pois, as políticas de inclusão no município de Macapá também incorporaram o discurso neoliberal, que tenta promover uma inclusão aos moldes da hegemonia do capital.

Dessa forma ocorre o discurso hegemônico nas diretrizes da Educação Especial de Macapá (2012), particularmente ao analisar as concepções e fundamentos do projeto de educação inclusiva para os alunos com deficiência intelectual, observando os modelos de educação em que se concebe a educação destes no município em estudo. Pois é deste lócus que se inicia toda a estruturação e sistematização da vida escolar de seus munícipes. 


\subsection{Os alunos com deficiência intelectual e os (des) compromissos assumidos nas metas do Plano de Educação Municipal}

As pessoas com deficiência intelectual, de acordo com a Política Nacional de Educação Especial na Perspectiva Inclusiva (BRASIL, 2010), conceituam-se como "aquelas que têm impedimentos de longo prazo, de natureza física, mental ou sensorial que, em interação com diversas barreiras, podem ter restringida sua participação plena e efetiva na escola e na sociedade" (BRASIL, 2010, p. 21). Desta forma, as políticas de inclusão devem se organizar no atendimento as necessidades específicas de seu alunado. Por isso que o poder público municipal responsável por tais ações, vem organizar o seu sistema de ensino traçando planos para um determinado fim nos diversos setores e modalidades educacionais. Assim, a quarta meta corresponde às determinações para a educação especial propondo que:

Universalizar, para a população de quatro a dezessete anos com deficiência, transtornos globais do desenvolvimento e altas habilidades/superdotação, o acesso à Educação Básica e ao atendimento educacional especializado preferencialmente na rede regular de ensino, com garantia de sistema educacional inclusivo, de salas de Recursos Multifuncionais (SRM) e de classes, escolas ou serviços especializados, públicos ou conveniados (MACAPÁ, 2015, p. 12).

A partir desta meta, percebe-se que as determinações apresentadas no Plano de Educação Municipal não se configuram prontamente aplicáveis, pois universalizar o acesso a educação básica e ao AEE, preferencialmente na rede regular dentro de uma análise do discurso significa a não obrigatoriedade do ensino inclusivo nas escolas públicas. Também, o movimento do governo Federal tem sido de instalação de salas de recursos multifuncionais nos municípios que aderiram a esta política, apontando a tendência da educação brasileira, como uma proposta inclusiva, efetivando o movimento de contingências econômicas (KASSAR, 2009). Segundo Shiroma, Campos e Garcia (2005) a implementação destas políticas "exige que sejam traduzidas, interpretadas, 
adaptadas de acordo com as vicissitudes e os jogos políticos que configuram o campo da Educação" (p. 430).

É preciso compreender a racionalidade nas informações deste documento, que muitas vezes se apresentam na contradição dos textos das políticas, onde oferecem medidas que aparentam ir em direção contrária ao que propõem (SHIROMA; CAMPOS; GARCIA, 2005).

Neste caso, apenas expandir a matrícula e implantar SRM não garante a materialidade da escola e ensino concretamente inclusivo. Para que aconteçam mudanças na implementação das políticas inclusivas, faz necessário um estudo e uma compreensão maior na interpretação de conceitos, vocábulos e teorias que se apresentam no corpo dos textos das políticas oficiais. Para além disso, é necessário reconfigurar o papel político do Estado frente aos direitos e serviços públicos.

Na estratégia 4.1 do referido Plano de Educação Municipal, são abordados os recursos para a Educação Especial, destacando que há uma necessidade de contabilizar o quantitativo de alunos conforme registro do censo escolar para o controle dos recursos do Fundo de Manutenção e Desenvolvimento da Educação Básica e Valorização do Magistério (FUNDEB), (MACAPÁ, 2015).

Considera-se importante enfatizar a necessidade de aprofundamento e esclarecimento sobre os recursos destinados para a Educação Especial, sobre a forma de detalhamento destes recursos e como eles chegam à sala de alunos com deficiência intelectual. Também não é possível negar a influência de instituições não públicas que aos poucos vão tomando os espaços das escolas públicas. Neste caso, surgem as seguintes questões: Quais as implicações da contabilização do quantitativo no censo escolar para o ensino dos alunos com deficiência? Para quê e para quem servirá este controle dos recursos do FUNDEB? Esses são questionamentos para reflexão, visto que ainda carecem de esclarecimento por parte do documento. 
Políticas dE EDUCAÇÃo ESPECIAL: ANÁLISE DO PLANO DE EDUCAÇÃo (2015 - 2025) E DIRETRIZES DA EDUCAÇÃO ESPECIAL (2012) DE MACAPÁ-AP

Neste sentido as políticas de inclusão no contexto brasileiro que desde a década de 1990, gestadas sob a égide neoliberal enviesam a perspectiva do desenvolvimento humano como forma de minimizar ou silenciar a exclusão dos alunos com deficiência ao longo da história, com o "discurso humanitário de garantia de direitos humanos" (SOUZA; DAINEZ; MAGIOLINO, 2015, p. 32). Com isso, a educação dos alunos, público alvo da educação especial ${ }^{1}$, deve acontecer em salas de aula do ensino regular, com apoio da Educação Especial, realizada pelo Atendimento Educacional Especializado de forma suplementar ou complementar no contra turno do ensino regular (BRASIL, 2010). É lógico, que estas Diretrizes protagonizam a atribuição oferecidas a Educação Escolar, no sentido de provocar a sustentabilidade econômica dos países compromissados com a agenda neoliberal (RABELO; JIMENEZ; SEGUNDO, 2015).

Os municípios brasileiros são os primeiros a receber tal alunado a partir dos acordos realizados com a União e os Estados, com o compromisso de construir, estruturar e implementar políticas, planos e diretrizes no sentido de promover o desenvolvimento humano destes alunos na modalidade de Ensino Fundamental, que é a base de toda a educação. É questionado se realmente as metas e estratégias destes documentos são capazes de atender as necessidades básicas para provocar o aprendizado.

Para responder tal questionamento, apresenta-se a estratégia 4.3 que tem a pretensão de:

Implantar e manter ao longo do PME, em parceria com o Governo Federal, financiamento para construção e estruturação das Salas de Recursos Multifuncionais (SRM), em 100\% das escolas municipais, com os recursos tecnológicos que atendam à necessidade de alunos com necessidades especiais, bem como garantir a formação continuada de docentes para o AEE, tanto nas escolas urbanas quanto nas do campo, voltadas as populações de assentamentos, extrativistas, indígenas, negras, quilombolas e ribeirinhas (MACAPÁ, 2012, p. 12). 
Nesta direção, vale destacar o discurso de realizar uma tarefa em percentuais máximos, no caso de 100\%, em que a maioria das vezes não se chega ao mínimo do esperado, devido à estrutura precária do sistema que gerencia as políticas educacionais. Para implantar e manter uma sala de recursos multifuncional com recursos federais é preciso perceber se realmente as parcerias acontecem de forma satisfatória, com uma gestão que assuma seus compromissos com a esfera pública.

Segundo Pletsch (2010), nos discursos veiculados sobre financiamento da educação inclusiva vem se propagando como recursos suficientes, incumbindo ao Estado administrar da melhor forma possível, basta articular a sociedade no sentido do voluntarismo cívico.

Com essas medidas, é reduzido o recurso público para a educação em todas as áreas, comprometendo radicalmente a qualidade do ensino. Para Pletsch (2010) "o percentual de 3,5\% do PIB não apenas é insuficiente para as necessidades educacionais reais do país, como, frequentemente sequer é cumprido.”( p. 57).

Um ponto a ser destacado refere-se à implementação de uma política de educação inclusiva fora dos espaços urbanos como é o caso de comunidades ribeirinhas, quilombolas, indígenas e outros, sem fazer um estudo prévio para conhecer a realidade e necessidade de cada local. Pois, de acordo com Oliveira (2015) implantar uma SRM no meio da Amazônia é um tanto contraditório devido às especificidades das populações que, na maioria dos casos, não possuem um aparato adequado (necessário para suportar a estrutura tecnológica) para o funcionamento, as questões de melhoria de infraestrutura deveriam ser prioridades. Ações desta natureza contribuem para o gasto público na aquisição de materiais fadados ao desuso e empilhamento em salas de recursos multifuncionais.

A estratégia 4.26 aprofunda mais o debate sobre a desresponsabilização do município no que concerne a inclusão do aluno com deficiência na escola, ao focar sobre 
Políticas dE EDUCAÇÃo ESPECIAL: ANÁLISE DO PLANO DE EDUCAÇÃo (2015 - 2025) E DIRETRIZES DA EDUCAÇÃO ESPECIAL (2012) DE MACAPÁ-AP

o acesso e permanência no que permitir, ou seja, no que for possível que as salas de aula regular ofereçam condições de permanência e aprendizagem para todos, atendendo um número máximo de 25 alunos incluindo os alunos com deficiência (MACAPÁ, 2015).

Neste sentido, garantir acesso e permanência com qualidade para todos dentro de um sistema que se mantem pela via da exclusão fica comprometido, visto que as políticas educacionais não garantem o desenvolvimento pleno dos alunos, sejam eles com ou sem deficiência. Dentro desta lógica, expressões inconclusas mantem um cenário de descompromissos e distante da participação popular no engajamento por uma inclusão escolar efetivamente real. Garcia (2004) adota a compreensão:

Segundo a qual INCLUSÃO consiste na relação travada em contexto histórico-social, por sujeitos sociais, ou seja, uma prática complexa e contraditória, com sentido de luta, de embate, que convive necessariamente com seu contrário - a exclusão -, mas que se estabelece na direção de questionar e superar práticas sociais baseadas na desigualdade (GARCIA, 2004. p. 02, grifo nosso).

Não obstante, faz-se necessário desenvolver uma análise das políticas de inclusão no contexto de suas conjecturas, não evidenciando apenas como ações ou medidas, mas como objeto de contestação, como um processo fruto de discussões (GARCIA, 2004). Rompendo com o discurso de que as políticas educacionais não se materializam na prática, Fairclough (2001) enfatiza que na atual estrutura política neoliberal, os discursos já são práticas que se põem sob suas próprias concepções.

\subsection{Diretrizes para a Educação Especial de Macapá (2012) e a concepção de deficiência intelectual}

De acordo com Shiroma, Campos e Garcia (2005) é necessário interpretar os textos e suas entrelinhas para poder compreender as políticas públicas. Os discursos propagados no corpo dos textos estão carregados de conceitos e concepções contraditórias, visto que, a estrutura da linguagem mostra incompreensões, fragmentação com 
foco fora da realidade ao qual estão sendo aplicadas tais políticas. Deste modo, quando se analisa um documento que determina os caminhos da educação de determinado grupo de alunos, deve-se perceber de que forma essa política está concebendo tal alunado.

Segue esta mesma linha de análise os fundamentos que compõem o texto das Diretrizes para a Educação Especial no Município de Macapá (2012), pois apontam para a concretude das políticas sob a égide do capital, quando enfatizam que o sistema de ensino municipal deve se organizar de forma a assegurar "a igualdade de oportunidade, o respeito às diferenças e a valorização da diversidade no processo educativo" (MACAPÁ, 2012, p. 10).

Ao conceber esses valores como condição para Inclusão Escolar, está implícita a ideia de que a inclusão do aluno dependerá dele mesmo, visto que ao receber o tratamento igual, será negado as suas peculiaridades e necessidades básicas, desconsiderando as formas de aprender de cada um. Para Bakhtin (2006) "o discurso constitui uma superestrutura, visto que as relações entre linguagem e sociedade são colocadas sob o signo da dialética, enquanto efeito das estruturas sociais.”( p. 16).

Seguindo este mesmo raciocínio, foca-se para a concepção de deficiência intelectual contida na diretriz para a Educação Especial do Município de Macapá, que a conceitua como "limitações significativas no funcionamento intelectual e no comportamento adaptativo e está expresso nas habilidades práticas, sociais e conceituais, originando-se antes dos dezoito anos de idade" (Macapá, 2012, p. 44). Percebe-se claramente o enfoque clínico da deficiência e aponta a dificuldade de definir entre deficiência mental e intelectual, fortalecendo os estigmas sobre as pessoas com deficiência.

Segundo Pletsch (2010), a atual definição e classificação de deficiência mental apresentada pela Associação Americana de Retardo Mental - AAMR (2006), apesar de 
Políticas dE EDUCAÇÃo ESPECIAL: ANÁLISE DO PLANO DE EDUCAÇÃo (2015 - 2025) E DIRETRIZES DA EDUCAÇÃO ESPECIAL (2012) DE MACAPÁ-AP

suas várias reformulações ao longo da história, ainda estigmatiza e é usada erroneamente como resultado global a respeito de seres humanos complexos. Mesmo com uma nova terminologia é preciso lembrar que a definição de deficiência intelectual continua tendo como base o conceito de deficiência mental da AAMR (PLETSCH, 2010), o qual está presente no documento que norteia os caminhos da Educação Especial do Município de Macapá.

Contrapondo ao modelo clínico, o enfoque social sobre a deficiência considera que este sujeito deve ser visto na sua totalidade, ou seja, na sua condição bio-psicosocial (VYGOTSKY, 1997). Para este autor, as deficiências são definidas em primárias e secundárias. A primária se refere a sua condição biológica, causada por questões genéticas ou hereditárias, já a deficiência secundária é aquela definida pelo meio social ao qual o individuo está inserido, ocasionando as barreiras para o desenvolvimento das funções psicológicas superiores. Em outras palavras, são as "funções psíquicas superiores, o produto do desenvolvimento histórico dos humanos" (Vygotsky, 2001, p. 64). Aponta ainda, que as barreiras impostas pelo social são fatores que geram as deficiências secundárias.

Desse modo, as relações sociais, tanto na família como na escola e outros setores da sociedade, assim como a formulação de políticas e gerenciamento adequado devem contribuir de forma significativa para o desenvolvimento das pessoas com deficiência. Caso contrário, as mesmas ficarão à margem dos processos de aprendizagem e de adquirirem consciência para administrar com autonomia suas vidas.

Outro ponto de análise da Diretriz está no discurso fidedigno das políticas e dispositivos legais nacionais que seguem as bases internacionais, confirmando o discurso das políticas neoliberais, que nas últimas décadas sustentam os instrumentos que direcionam a educação especial nos municípios brasileiros. Um projeto maior de inclusão está em vigor e a tendência é que os partícipes estejam no mesmo caminho como 
forma de atender aos organismos que determinam os destinos dos países pobres ou em desenvolvimento.

Sendo assim, este se constitui como um instrumento que flutua nas contradições emergindo no meio social como fator ideológico. "A ideologia se monta como reflexo das estruturas sociais, onde toda tendência ideológica encadeia uma modificação no discurso" (BAKHTIN, 2006, p. 16). Na análise de Shiroma, Campos e Garcia (2005), a hegemonia discursiva aponta uma tendência crescente da homogeneização das políticas em nível mundial. Constituindo-se de elementos dos contextos das políticas internacionais que apontam medidas exitosas, isso permite compreender a natureza destas ações que são recomendadas aos países subdesenvolvidos.

A partir da concepção de deficiência intelectual, existente na Diretriz para a Educação Especial do município em estudo, analisa-se de que forma é vista a avaliação da aprendizagem no processo de inclusão. É conceituada como "processual, diagnóstica, formativa, participativa e cumulativa" (MACAPÁ, 2012, p. 61). E faz referência a avaliação diagnóstica, por permitir a "mediação por parte do professor na Zona de Desenvolvimento Proximal do aluno” (MACAPÁ, 2012, p. 62).

Segundo Prieto (2006), os avanços são inegáveis para o campo da Educação Especial, porém, o resultado das avaliações tem demostrado que a aprendizagem dos alunos está aquém do esperado. Para a autora é preciso cumprir com os objetivos estabelecidos na CF de 1988 para a educação, sendo um dos principais a "erradicação do analfabetismo, universalização do atendimento escolar, melhoria da qualidade de ensino, formação para o trabalho e promoção humanística, científica e tecnológica do país" (PRIETO, 2006, p. 50).

É fato que a política educacional brasileira tem deslocado de maneira progressiva para os municípios parte da responsabilidade administrativa, financeira e pedagógica pelo acesso e permanência de alunos com deficiência em decorrência do processo 
Políticas de educaÇão especial: ANÁLise do Plano de EDUCAÇão (2015 - 2025) E DIRETRIZES DA EDUCAÇÃO ESPECIAL (2012) DE MACAPÁ-AP

de municipalização do ensino fundamental. Assim, os municípios se organizam de acordo com planos e diretrizes formulados para estruturar e determinar o funcionamento das ações. Para Prieto (2006) o que se espera destes documentos é que eles sejam capazes de apontar propostas claras que favoreçam a aprendizagem e desenvolvimento de todo o seu alunado.

\section{Considerações finais}

Nas análises do discurso realizadas nesta pesquisa documental, percebeu-se que as políticas implantadas para a Educação Especial seguem as determinações de documentos internacionais como forma de regular a educação nos países que utilizam do capital internacional, como é o caso do Brasil.

As políticas de inclusão em estudo se configuram como pontos de interpretação da realidade que se vivencia em torno da educação das pessoas com deficiência intelectual. Diante disso, torna-se relevante levantar questionamentos sobre o processo de aquisição do saber, visto que, ao longo dos processos inclusão escolar os alunos com deficiência sempre estiveram à margem. É fato que estas crianças estão adentrando nas escolas em idade certa, porém, não estão dando continuidade nos seus estudos de forma efetiva e com qualidade de aprendizagem.

Os discursos apresentados nas políticas, segundo Shiroma, Campos e Garcia (2005), focalizam afirmações sobre o mundo em que se vive, como também, pretendem oferecer representações únicas da realidade, e ainda "trazem soluções idealizadas para problemas diagnosticados" (SHIROMA; CAMPOS; GARCIA, 2005, p. 13). É como se as análises dos discursos funcionassem como instrumentos de regulação para camuflar o que não pode se tornar evidente.

Considerando que as políticas na perspectiva inclusiva apontam para um descompasso entre a realidade concreta das escolas e as políticas propostas, onde se tem 
uma visão idealizada de educação, de escola e de aluno (SOUZA; DAINEZ; MAGIOLINO, 2015), torna-se profundamente urgente lutar pela criação de políticas que realmente se preocupem com o desenvolvimento dos alunos, principalmente dos alunos com deficiência.

Não se pode negar que nos textos das políticas há a ideia, sim, de desenvolvimento. Entretanto, a lógica apresentada está sustentada nos índices de desenvolvimento humano (IDH) dentro da sustentabilidade do capital (SOUZA; DAINEZ; MAGIOLINO, 2015).

Desta forma, esta definição foge do ideal de homem propagado pela teoria histórico cultural do desenvolvimento ao qual esta pesquisa se referencia, na qual segundo Vygotsky (1997), o homem deve se constituir observando todos os aspectos de seu desenvolvimento na totalidade como ser bio-psico-social.

Neste sentido, os documentos oficiais que determinam o caminhar da educação dos alunos com deficiência devem contemplar um discurso onde favoreça um "intenso processo de trabalho coletivo, de constituição dos sujeitos e de produção de conhecimentos na trama das relações sociais e práticas escolares" (SOUZA; DAINEZ; MAGIOLINO, 2015, p. 03).

Diante do que foi dito sobre a análise dos discursos apresentados nos planos de educação e nas diretrizes para a Educação Especial do Município de Macapá, constatou-se que são projetos de educação inclusivos distintos e em constante disputa, tanto projeto hegemônico neoliberal de Inclusão escolar quanto aquele que é resultante das lutas dos movimentos sociais. Entretanto, sabe-se que como está posto nos documentos oficiais, hegemonicamente segue a lógica (princípios) do projeto neoliberal e ao enfoque médico da deficiência, ao atribuir a concretização da educação inclusiva exclusivamente a escola, a família e do próprio aluno como responsáveis pelas mudanças no processo de exclusão. 
Políticas dE EDUCAÇÃo ESPECIAL: ANÁLISE DO PLANO DE EDUCAÇÃo (2015 - 2025) E DIRETRIZES DA EDUCAÇ̃̃o ESPECIAL (2012) DE MACAPÁ-AP

Porém para além destas análises, o que deve ser considerado e ponderado é que da forma com está efetivada a educação de meninas e meninos com deficiência intelectual precisa ser repensada, avaliada, estudada, constituídas por políticas cujo foco deve incidir diretamente no aprendizado deste aluno, pensando no seu desenvolvimento pleno, consequentemente os planos e diretrizes dos municípios brasileiros devem ser propícios para uma educação eminentemente de qualidade. Tendo estes incluídos no todo do sistema escolar, aprendendo com qualquer criança que adentra na escola em idade certa.

\section{Nota:}

${ }^{1}$ A nova política da Educação Especial na Perspectiva Inclusiva (2008) define o público alvo da Educação Especial: alunos com deficiência, transtornos globais do desenvolvimento e altas habilidades/superdotação.

\section{Referências}

BAKHTIN, Mikhail. Marxismo e filosofia da linguagem. 12. ed. São Paulo: HUCITEC, 2006.

BRASIL. Constituição Federal de 1988, artigos 208 e 211. Constituição da República Federativa do Brasil. Disponível em: <http://www.planalto.gov.br/ccivil_03/constituicao/constituicao.htm>. Acesso em: 20 nov. 2016.

E.C. no 59/2009. Constituição Federal de 1988, artigo. 212. De 11 de novembro de 2009. Brasília-DF. Disponível em: $<$ http://www.planalto.gov.br/ccivil 03/constituicao/emendas/emc/emc59.htm $>$. Acesso em: 17 nov. 2016. 
. MEC. Lei de Diretrizes da Educação Básica Nacional- LDBEN - no 9.394/ 1996.

Brasília, 1996. Disponível em < http:/ /www.planalto.gov.br/cci-

vil_03/leis/L9394.htm>. Acesso em: 17 nov. 2016.

. MEC/SEESP. Marcos Politicos-Legais da Educação Especial na Perspectiva Inclu-

siva. p.72. Brasília: SEESP, 2010. < http://portal.mec.gov.br/index.php?op-

$\underline{\text { tion }}=\mathrm{com}$ docman\&view $=$ download $\&$ alias $=6726-$ marcos-politicos-legais $\& I t e-$

$\underline{\operatorname{mid}=30192}>$. Acesso em: 18 out. 2018.

BOROWSKY, Fabíola. A relação entre a educação pública e a privada na Educação Especial brasileira. In: PERONI, Vera (Org.) Redefinições das fronteiras entre o público e o privado: Implicações para a democratização da educação. Liber Livro. p, 308-326. Brasília, 2013.

CORRÊEA, Nesdete Mesquita; KASSAR, Mônica de Carvalho de Magalhães. Municipalização em tempos de Reforma do Estado: A Educação Especial em foco. Uberlândia, 2009. Disponível em <http://www.simposioestadopoliticas.ufu.br/imagens/anais/pdf/BC16>. Acesso em: 20 nov. 2016.

FAIRCLOUGH, N. Discurso e mudança social. Tradução: Izabel Magalhães. Brasília: UNB, 2001.

FARENZENA, Nalú; MACHADO, Maria Goreti Farias. O custo das escolas públicas municipais: resultados de uma pesquisa e implicações políticas. Revista Brasileira de Política e Administração da Educação. v. 22, n. 2, p. 277-290, jul./dez. 2006.

GARCIA, Rosalba Maria Cardoso. Discursos políticos sobre inclusão: questões para as políticas públicas de Educação Especial no Brasil. 27ª Reunião Anual da ANPEd. Caxambu, 2004. Disponível em: < http://27reuniao.anped.org.br/gt15/t1510.pdf>. Acesso em: 20 nov. 2017.

GIL, Juca et al. Gestão das políticas de atendimento aos alunos com necessidades educacionais especiais em municípios paulistas. In: Jornal de Políticas Educacionais. $\mathrm{N}^{\circ} 7$. Jan. - jun. 2010.

JANNUZZI, Gilberta. A educação do deficiente no Brasil: dos primórdios ao início do século XXI. 2. ed. Campinas, SP: Autores Associados, 2006. 
Políticas de educaÇão especial: ANÁLise do Plano de EDUCAÇão (2015 - 2025) E DIRETRIZES DA EDUCAÇ̃̃O ESPECIAL (2012) DE MACAPÁ-AP

KASSAR, Mônica de Carvalho Magalhães. Proposta de Educação Inclusiva: uma nova política? In: MARQUEZINE, Maria Cristina et al (Orgs.). Políticas Públicas e formação de recursos bumanos em Educação Especial. Londrina: ABPEE, 2009.

- Percursos da constituição de uma política brasileira de educação Especial inclusiva. Revista Brasileira da Educação Especial, Marília, v.17, no especial, p. 41-58, maio/ago. 2011. Disponível em: < http://www.scielo.br/scielo.php?script=sci arttext\&pid=S1413-65382011000400005\&lng $=$ pt\&nrm=iso\&tlng $=$ pt $>$

KASSAR, Mônica de Carvalho Magalhães; DE OLIVEIRA, Andrea Duarte; da SILVA, Giane Aparecida Moura. Inclusão em escolas municipais: análise inicial de um caso. Educaşão (UFSM), v. 32, n. 1, 2007. Disponível em:

< http://www.redalyc.org/pdf/1171/117117241009.pdf. >

MACAPÁ . P. M. M. Diretrižes para a Educaşão Especial . PMM/SEMED/DIEES, 2012. $(2015-2025)$.

. Lei n. 2.178/2015, PME/CMM, 2015. Plano Municipal de Educação de Macapá

OLIVEIRA, Ivanilde Apoluceno de. Políticas e práticas de inclusão de pessoas com deficiência na Amazônia paraense: um olhar a partir de produções acadêmicas. p. 54. In: ANJOS, Hildete Pereira dos (Org.). Olhando a educação como um direito: inclusão e diversidade. Belém: Paka-Tatu, 2015.

PERONI, Vera. Políticas educacionais e a relação público/privado. In: 32. ${ }^{a}$ Reunião Anual da ANPEd. Caxambu, MG, 2009.

PLETSCH, Márcia Denise. Repensando a inclusão escolar: diretrizes políticas, práticas curriculares e deficiência intelectual. Rio de Janeiro: Nau. Edur, 2010.

PRIETO, Rosângela Gavioli. Atendimento escolar de alunos com necessidades educacionais especiais: Um olhar sobre as políticas públicas de educação no Brasil. In: MANTOAN, Maria Teresa Eglér; PRIETRO, Rosângela Gavioli; ARANTES, Valéria Amorim (Orgs.). Inclusão escolar: Pontos e Contrapontos. São Paulo: Summus, 2006.

RABELO, Jackline; JIMENEZ, Susana; SEGUNDO, Maria das Dores Mendes (Org.). O movimento de Educação para todos e a crítica marxista. Fortaleza: Imprensa Universitária, 2015.

Cadernos de Pós-graduação, São Paulo, v. 17, n. 2, p. 197-221, jul./dez. 2018. 
SHIROMA, Eneida Oto; CAMPOS, Roselane Fátima; GARCIA, Rosalba Maria Cardoso. Decifrar textos para compreender a política: subsídios metodológicos para análise do documento. Florianópolis. v. 23, n. 02, p. 427- 446, jul./dez. 2005. Disponível em <http://www.ced.ufsc.br/nucleos/nup/perspectiva.html>. Acesso em: 21 nov. 2017.

SILVA, M. L; OLIVEIRA, M. Da reprodução à contraposição ao discurso hegemônico da política de formação docente: um estudo com os professores que atuam com alunos com síndrome de Down. In: ANJOS, Hildete Pereira dos (Org.). Olhando a Educaşão como um direito: inclusão e diversidade. Belém: Paka-Tatu, 2015.

SOUZA, D. B. de; FARIA, L. C. M de. Reforma do Estado, descentralização e municipalização do ensino no Brasil: a gestão política dos sistemas públicos de ensino pós LDB 9.394/96. Ensaio: avaliação e políticas públicas em educação, Rio de Janeiro, v.12, n. 45, p. 925-944, out./dez. 2004. < http://www.scielo.br/pdf/\%0D/ensaio/v12n45/v12n45a02.pdf>

SOUZA, F. F; DAINEZ, Debora; MAGIOLINO, L. L. S. Educação e Desenvolvimento Humano: modos de mediação e participação nos meandros das práticas educacionais inclusivas. In: PLETSCH, Márcia Denise; MENDES, Geovana Mendonça Lunardi; HOSTINS, Regina Célia Linhares (Orgs.). A escolarização de alunos com deficiência intelectual: políticas, práticas e processos cognitivos. p, 15-30. São Carlos: Marquezine \& Manzini: ABPEE, 2015.

VYGOTSKI, L.S. Obras Escogidas: Fundamentos da Defectologia. Vol. V. Madrid: Visor, 1997. 2001.

- A defectologia e o estudo do desenvolvimento e da educaşão da criança. Madrid: Visor,

recebido em 4 ago. 2017 / aprovado em 14 set. 2018

Para referenciar este texto:

SANTOS, M. M.; SILVA, M. C. L.; BARLETA, I. A. Políticas de educação especial: análise do plano de educação (2015 - 2025) e diretrizes da educação especial (2012) de Macapá-AP. Cadernos de Pós-graduação, São Paulo, v. 17, n.2, p. 197-221, jul./dez. 2018. Disponível em: $<$ https://doi.org/10.5585/cpg.v17n2.7647>. 


\section{Políticas de InCLUSÃo E A REALIDAdE PROFISSIONAL: A EXPERIÊNCIA DE UMA GRADUANDA CEGA NO ESTÁGIO CURRICULAR SUPERVISIONADO}

INCLUSION POLICIES AND THE PROFESSIONAL REALITY: THE EXPERIENCE OF A BLIND GRADUATE IN THE SUPERVISED CURRICULAR INTERNSHIP

Kalina Salaib Springer Doutora em Geografia pela Universidade Estadual de Campinas. Docente da Universidade Federal de Santa Catarina. Santa Catarina - SC - Brasil springer.kalina@gmail.com

Sabrina Mangrich de Assunção Graduada em Geografia pela Universidade Federal de Santa Catarina. Santa Catarina - SC - Brasil sabrina.m.a@hotmail.com

Yanna D'Angelis de Carvalho Gonçalves Mestranda em Geografia pela Universidade Federal de Santa Catarina. Santa Catarina

- SC - Brasil yannaufsc@hotmail.com

Resumo: Neste texto, abordaremos aspectos relacionados às políticas de inclusão de pessoas com deficiência e seus desdobramentos no que tange à inserção deste indivíduo no mercado de trabalho. Para tanto, relataremos a experiência de uma graduanda cega, em seu estágio 
curricular obrigatório no curso de Licenciatura Plena da Universidade Federal de Santa Catarina. Percebeu-se, que, mesmo com toda a política de inclusão já existente, a escola e os alunos, não estão preparados para receber um docente cego ${ }^{1}$. A inclusão envolve a adequação das escolas e da sociedade para receber essas pessoas, de modo a promover a cidadania, como pessoas possuidoras dos mesmos direitos, dentre eles o direito de estudar e trabalhar.

Palavras-chave: Inclusão. Política educacional. Realidade profissional.

Abstract: In this text, we will discuss aspects related to the policies of inclusion of people with disabilities and their consequences regarding the insertion of this individual in the labor market. To do so, we will report on the experience of a blind undergraduate student1, in her compulsory curricular internship in the Full Degree course of the Federal University of Santa Catarina. It has been realized that, even with all the existing inclusion policies, the school and the students are not prepared to receive a blind teacher. This involves the adequacy of schools and society to receive these people, in order to promote citizenship, as persons having the same rights, among them the right to study and work.

key-words: Inclusion. Educational policy. Professional reality.

\section{Introdução}

questão da inclusão de pessoas com deficiência $(\mathrm{PCD})^{2}$ ainda é muito
incipiente no Brasil. A estrutura de nossa sociedade, desde os seus primórdios, contribuiu para o processo de marginalização e exclusão social destas pessoas. Contudo, este pensar discriminatório, tem sido, combatido sobretudo por ações de educadores e de pais que, buscam por meio do conhecimento a alteração da visão social destas pessoas; sua inclusão na rede escolar; criação e acatamento à legislação vigente e ampliação de verbas para programas sociais.

É nesse contexto de lutas, que surge a Política de Inclusão de Pessoas com Deficiência no Brasil, das quais muitos já se beneficiaram. Partindo dessa premissa é objetivo deste artigo refletir se a política de inclusão proporciona uma efetiva inclusão daqueles por ela beneficiados. Assim, para além de um apanhado histórico acerca das políticas de inclusão, abordaremos facilidades e dificuldades encontradas no âmbito profissional. 
Tais reflexões objetivam trazer subsídios para compreender se, estas políticas promovem a inclusão, proporcionando as bases para, ao final do curso, estes profissionais ingressarem no mercado formal de trabalho. Por outro lado, é objetivo também, refletir se, o mercado de trabalho, está preparado para receber estes profissionais, promovendo uma efetiva inclusão e não somente a integração destas pessoas.

Estas reflexões tiveram como base a experiência docente realizada durante o estágio curricular supervisionado no curso de Licenciatura Plena da Universidade Federal de Santa Catarina. Apresentando-se como um estudo de caso, esta pesquisa realizou-se no Colégio de Aplicação (UFSC), local de realização do estágio em uma turma do ensino médio no ano de 2016.

\section{A política de inclusão no Brasil: breves considerações}

A Educação Especial no Brasil é marcada por diversas fases segundo afirma Sassaki (1997), sendo elas: exclusão, segregação institucional, integração e inclusão. Para o autor, na fase da exclusão as pessoas com deficiências eram ignoradas, rejeitadas, perseguidas e exploradas, não havendo nenhuma forma de atenção educacional.

Já, na fase da segregação institucional surgiu a ideia de deficientes na educação, tendo em vista, a política educacional brasileira. Com isso, iniciou-se a preocupação com o desenvolvimento educacional das pessoas cegas, surdas, deficientes mentais e deficientes físicos, através do atendimento educacional nas chamadas instituições especializadas.

Assim, nas décadas de 1950 e 1960 houve várias iniciativas na área da educação especial, refletindo num aumento considerável de serviços de ensino especial. Um exemplo desse processo foi a criação de instituições filantrópicas, como a fundação da 
GRADUANDA CEGA NO ESTÁGIO CURRICULAR SUPERVISIONADO

Associação de Pais e Amigos do Excepcional (APAE) em 1954. Mazzota (1996) relata que em 1957, o governo brasileiro iniciou campanhas, com a finalidade de atender a cada deficiência, de modo que, os surdos foram os primeiros a serem contemplados.

Apenas em 1961, a educação de excepcionais, como era denominada educação especial, teve um capítulo com os artigos 88 e 89 na LDB: "A educação de excepcionais, deve, no que for possível, enquadrar-se no sistema geral de educação, a fim de integrálos na comunidade" (Art. 88, LDB, n. $\left.{ }^{\circ} 4.024 / 61\right)^{3}$. Assim, as pessoas com deficiência passam a ter o direito de frequentar o ensino regular. Para Mazzota (1996) este foi um avanço, pois garantiu o direito à educação no ensino regular, sendo a primeira menção a este grupo nas políticas educacionais brasileiras.

Com a inserção destes alunos no ensino regular, surge a fase da integração. De acordo com Sassaki (1997) esta fase inicia-se com expressivo aumento das classes especiais nas escolas de ensino regular, porém em espaços separados dos demais. Essas salas se baseavam na compreensão de que estando em salas à parte, separados dos alunos sem deficiência, os ditos "excepcionais" não atrapalhavam o ensino dos demais. Nesse mesmo sentido, Blanco (2002, p.08), menciona que “[...] assim, quando se começa uma experiência de integração, é reproduzido, no interior da escola, o mesmo enfoque da escola especial".

Colocando assim, o termo 'integração’ se refere a inserir no convívio social a pessoa com deficiência que já tenha sido preparada, capacitada, instruída e que esteja adaptada para viver em sociedade. Assim, esta 'integração' ocorreu de forma relativa, visto que os alunos passavam por um treinamento, uma adaptação para se adequar tanto na educação regular, quanto na vida social. Destaca também, que a escola permaneceu sem alterações, dividida entre a educação regular e a especial, sendo o enfoque nas patologias. Como complementa Glat e Nogueira (2002): 
Denominamos integração o modelo que começou a serem implantados no Brasil desde o final da década de 70, os alunos com necessidades educacionais especiais, geralmente oriundos do ensino especial, são inseridos na sala regular na medida em que demonstrem condições para acompanhar a turma, recebendo atendimento especializado paralelo, em horário alternativo, individualmente ou em salas de recursos. (GLAT; NOGUEIRA, 2002, p. 12).

Em 1972, foi constituído o grupo tarefa de educação especial, pelo ministério da Educação e cultura. Este grupo criou a primeira proposta de políticas e ações para educação especial no país. Para gerenciar, promover melhorias e expansão na educação especial, foi criado o Centro Nacional de Educação Especial (CENESP), órgão central vinculado ao MEC (MAZZOTA, 1996). Em 1986 este órgão passa a se chamar Secretaria de Educação Especial (SESPE), mantendo basicamente as mesmas atribuições. Ao fim de 1992, a SEESP passa a ser vinculada ao Ministério de Educação e Desporto.

Mazzota (1996) destaca que a partir do fim da década de 1980 e início dos anos 1990, as pessoas com deficiência começaram a se organizar em movimentos, promovendo encontros, palestras, simpósios, de forma a contribuir para ampliação da participação efetiva deste grupo, e conseguem levar suas necessidades e demandas às diversas esferas governamentais.

Mazzota (1996) destaca também, que a capacidade de pressão destes grupos organizados, tiveram reflexos significativos na elaboração das legislações em vários aspectos da vida social, tendo destaque as conquistas concretizadas na constituição federal de 1988 e nas constituições estaduais, como exemplo a seguridade social, reabilitação, trabalho e transporte.

A Constituição Federal de 1988, diz que o aluno com deficiência deveria estar na escola, e se possível sua educação deveria acontecer em classe regular de ensino, junto às demais crianças sem deficiência. Então no seu art. 205, aborda que deve haver 
GRADUANDA CEGA NO ESTÁGIO CURRICULAR SUPERVISIONADO

a educação para todos como direito subjetivo para que as pessoas possam conviver e interagir normalmente, atendendo a diversidade humana. Ainda aponta no seu artigo 206 e 208, respectivamente, o acesso e permanência na escola e afirma que deve haver o Atendimento Educacional Especializado (AEE) às pessoas com deficiência, preferencialmente, na rede regular de ensino.

Neste contexto, em 1999 publica-se o Decreto 3.298 que regulamenta a Lei no 7.853, de 24 de outubro de 1989 e dispõe sobre a Política Nacional para a Integração da Pessoa Portadora de Deficiência. A lei estabelece que, a educação especial está integrada ao ensino regular como modalidade que perpassa todos os níveis de ensino, sendo obrigatória e gratuita em estabelecimentos públicos de ensino.

Ainda na década de 1990 a Conferência Mundial sobre Educação Especial em Salamanca, redigiu um documento, estabelecendo diretrizes básicas, que subsidiaram a formulação e reforma nos sistemas educacionais para que estivessem que acordo com movimento de inclusão social. Fica estabelecido que, as escolas de Ensino regular devem educar os alunos, enfrentando todas as situações que possam gerar exclusão escolar: crianças com deficiências, que vivem nas ruas, que trabalham, superdotadas, em desvantagem social, ou ainda que apresentam diferenças linguísticas, étnicas e culturais.

Neste contexto, em 2001 o Congresso Nacional aprovou o texto da Convenção Interamericana para a Eliminação de Todas as Formas de Discriminação contra as Pessoas Portadoras de Deficiência por meio do Decreto Legislativo no 198, de 13 de junho. O texto ratifica os direitos e liberdades fundamentais para as pessoas com deficiência, definindo discriminação como toda atitude de diferenciação. E, a partir dele, surgem várias leis, decretos, diretrizes e normas que tratam de questões pertinentes a educação especial, promovem o ensino inclusivo e dispõe sobre os direitos das pessoas com PCDs ${ }^{4}$.

Cadernos de Pós-graduação, São Paulo, v. 17, n. 2, p. 223-238, jul./dez. 2018. 
Assim, toda a criança tem direito fundamental à educação, e deve ser dada a oportunidade de atingir e manter o nível adequado de aprendizagem; toda criança possui características, interesses, habilidades e necessidades de aprendizagem que são únicas. Com isso, os sistemas educacionais deveriam ser implementados no sentido de se levar em conta a vasta diversidade de tais características e necessidades.

Logo, a Declaração de Salamanca abriu caminho para um avanço significativo ao destacar a valorização da individualidade de cada educando independente de ser deficiente sensorial ou não. E, a escola, passa a ser pensada para que, consiga atender a todos em suas diferenças ou dificuldades individuais. Para Mazzotta \& Souza (2000, p.98), tal Declaração "tem sido o referencial básico para os mais recentes debates sobre Educação para Todos com a denominação de Educação Inclusiva”.

Assim, na fase da 'inclusão' segundo Mantoan (1997) e Sassaki (1997), a sociedade identifica a necessidade de adaptação entre as pessoas com deficiência e a sociedade e vice-versa. De acordo com Sassaki (1997) a integração significa inserção da pessoa deficiente preparada para conviver em sociedade e a inclusão significa modificação da sociedade como pré-requisito para que a pessoa com deficiência busque seu desenvolvimento e exerça sua cidadania. Quando nos referimos ao termo ‘inclusão’ significa conscientização, modificação, adaptação e preparação de uma sociedade para incluir as diversidades.

Conforme Glat e Nogueira (2002, p. 12) na inclusão, esses alunos, independente do tipo ou grau de comprometimento, devem ser matriculados diretamente no ensino regular, cabendo à escola se adaptar para atender às suas necessidades na classe regular. Assim Blanco (2002, p.31), coloca que "a instituição tem que incluir, sustentar, acompanhar, apoiar, enriquecer e oferecer tudo o que esta pessoa necessita em sua singularidade para ter êxito no objetivo de integrar". 


\section{O Estágio Supervisionado: Um Relato de Experiência}

O estágio supervisionado é o momento em que o graduando tem contato de forma direta com a escola, observa, interage, identifica problemas, aspectos positivos, e inicia a prática docente. Ele é indispensável por possibilitar um olhar sobre a complexa realidade da escola, existente no processo de ensino e de aprendizagem, bem como exercício de reflexão sobre esta realidade e, o contato e familiaridade com o cotidiano do espaço escolar. Assim, o estágio proporciona a oportunidade de vivência e aprendizagem da docência (MARTINS, 2014).

Esta experiência é uma oportunidade em que os licenciandos, têm para atuarem em Sala de aula e refletir sobre este ambiente, é também, um momento de aproximação com a realidade concreta da sala de aula, momento de incertezas, de aprendizagem profissional, crescimento tanto pessoal como coletivo, e outros inúmeros aspectos que permeiam esta etapa da formação, sendo o eixo central da formação acadêmica do licenciando (SANTOS, 2013; MARTINS, 2014).

Pimenta e Lima (2005) destacam que nos cursos em geral, o estágio sempre foi identificado como a parte prática em contrapartida a parte teórica vista nas disciplinas dos cursos, no entanto, a escola não deve ser percebida apenas como o local da prática e a universidade como da teoria. Teoria e prática se interpenetram ao se complementarem e interagem constantemente, portanto, não estão dissociados, visto que não existe prática sem teoria e vice-versa. Na docência são necessárias habilidades e competências concretas, por meio da teoria e da prática que estão articuladas ao ensino de forma a se relacionar e contextualizar ao momento atual, do ensino e do aprendizado (SANTOS, 2013).

Pimenta e Lima (2005) trazem que a teoria tem o papel de oferecer aos 
professores perspectivas de análise, que possibilita compreenderem os inúmeros contextos sociais, históricos, organizacionais, culturais e de si mesma como profissionais, onde ocorrem suas atividades docentes, para neles intervir e poder transformá-los.

Contreras (2002) destaca que a prática vai além de se dominar o conhecimento profissional ao se deparar com situações inesperadas, ela proporciona a construção de um sistema de valoração ao se tomar decisões e se ter a percepção do alcance social de suas ações. Martins (2014) lembra que a prática deve ser reflexiva, investigativa e problematizadora para que o futuro professor seja autônomo e responsável pelo seu processo de ensino e aprendizagem, tomada de decisões sobre sua prática e sua realidade na escola.

$\mathrm{Na}$ UFSC o estágio supervisionado do curso de licenciatura em Geografia ocorre em dois momentos, no decorrer de um ano letivo. No primeiro semestre, as duplas observam as aulas, o contexto escolar e planejam as aulas da regência para o segundo semestre assumirem a turma.

As observações ocorreram em duas turmas distintas. Em ambas turmas, os alunos agiram de forma natural à entrada da estagiária cega na sala. O Colégio de Aplicação têm políticas de inclusão de PCDs propiciando o convívio e consequente naturalização da deficiência, além disso, os alunos foram avisados previamente da condição da estagiária.

Durante as aulas observadas, a dupla de estágio auxiliava no entendimento geral ao descrever as situações que estavam ocorrendo, o que era passado no quadro, imagens projetadas e folhas de xerox entregues. As estagiárias sentavam-se no fundo da sala, circulando para auxiliar e conhecer melhor a turma durante os momentos de atividades.

Um detalhe que chamou atenção e despertava a curiosidade de alguns alunos era o fato da estagiária cega, escrever no tablet com a tela desligada e se utilizar um 
GRADUANDA CEGA NO ESTÁGIO CURRICULAR SUPERVISIONADO

teclado que utiliza pontos em braile, Os alunos, curiosos, mas envergonhados, perguntavam a estagiária vidente, que por sua vez pedia para a estagiária cega explicar.

Em paralelo, foi realizado o primeiro contato com a prática docente. A primeira regência ocorreu no fim de maio e abordou conteúdos da cartografia. Com enfoque para os elementos que compõe o mapa e a atividade foi desenhar a planta da sala, utilizando pés como unidade de medida. Já nessa primeira experiência, notou-se a falta de confiança dos alunos com relação à estagiária cega. Todos os questionamentos dirigiam-se primeiramente à estagiária vidente. Faltava aos alunos confiança e segurança com relação ao conhecimento e à capacidade da estagiária cega desenvolver as atividades docentes.

No segundo semestre as regências ocorrem de forma a integrar as aulas ministradas pelos estagiários ao conteúdo anual a ser ensinado em determinado nível escolar. Antes de iniciar as regências, observou-se que os alunos estavam ansiosos para que as estagiárias começassem. Assim, foi comentado sobre quais assuntos seriam abordados e as atividades a serem realizadas.

Baseando-se nas dificuldades identificadas pela estagiária cega na primeira regência, pediu-se aos alunos que adotassem procedimentos simples como, por exemplo: os alunos chamar pelo nome e não apenas levantar a mão para tirar dúvidas ou fazer algum comentário, não deixar mochila no chão, evitar deixar carteiras bagunçadas na hora das atividades, principalmente quando for à estagiária cega que estiver ministrando aulas. Esses procedimentos manteria a organização da sala, facilitando a locomoção da estagiária cega.

Nas primeiras aulas a ansiedade, insegurança, atrapalhou um pouco na explicação dos conteúdos. As aulas foram em dupla, utilizando-se vários slides com fotos, mapas e gráficos. Neste caso, a pessoa cega tem que ter clareza e segurança com relação às imagens a serem apresentadas, ou ter um mapa e esquemas táteis para auxiliar 
na explicação. Isso é necessário, pois, nem sempre os alunos irão conseguir descrever as imagens, como ocorreu algumas vezes em que foi pedido que eles descrevessem as imagens para participarem e perceber o que podiam compreender da mesma.

Para exemplificar, durante uma aula cujo tema era vegetação do estado de Santa Catarina, foi pedido que descrevessem as imagens que apareciam no slide bem como os mapas de vegetação e em resposta os alunos apenas diziam que era um mapa, ao serem instigado mais, para falar elementos de detalhe do mapa para, a partir disso, a graduanda cega conduzir a aula.

Em uma das aulas, a atividade era a elaboração de mapas táteis e texto auxiliar sobre os conteúdos clima, relevo, vegetação, hidrografia, geologia e geomorfologia de Santa Catarina. A sala foi dividida em duplas, onde cada dupla ficou responsável por um tema, tendo que fazer um resumo a partir de um texto base e um mapa tátil ${ }^{5}$.

Durante a execução a turma ficou agitada, e as estagiárias tiveram dificuldade em explicar e conduzir a atividade. Os alunos falavam ao mesmo tempo e as estagiárias tentavam se sobrepor as vozes a dos alunos. Essa falta de organização dos alunos, dificultava que a estagiária cega pudesse ouvir as indagações.

Outro ponto a ser mencionado é que a estagiária cega teve maior dificuldade em perceber a compreensão ou não dos assuntos pelos alunos. Diferentemente do professor vidente, durante a explicação, é importante que os alunos interajam, falem, deem exemplos. Já que não é possível ver a expressão da turma, isso é importante para que a pessoa cega possa ter o retorno de que eles estão compreendendo. Se ficam em silêncio, existe dúvida se compreenderam ou não.

Cabe ainda, relatar a experiência de um debate, em que, a turma foi dividida em dois grupos, "contra" e "a favor" da implantação de uma agroindústria, tendo que pesquisar e trazer argumentos. Para organizar a atividade, as carteiras foram dispostas em círculo, facilitando o deslocamento da estagiária cega. Além disso, pediu-se para que 
GRADUANDA CEGA NO ESTÁGIO CURRICULAR SUPERVISIONADO

os alunos, se identificassem no início de cada fala, estratégia importante para que a estagiária cega pudesse relacionar a voz ao aluno. Não se percebeu dificuldade e o debate prosseguiu com naturalidade, sendo que os próprios alunos lembravam uns aos outros de falar o nome.

De modo geral, as dificuldades encontradas pelas estagiárias eram as mesmas, contudo algumas potencializam-se na estagiária cega. Ainda sim, essas dificuldades e obstáculos não interferiram no andamento do estágio, mas exigiram da estagiária cega grande esforço, paciência e capacidade de adaptação.

As conversas paralelas e perguntas simultâneas dificultavam a explicação de ambas, e fazia com que a estagiária cega, por vezes, se perdesse no 'falatório' generalizado. A desorganização da turma com mochilas e bolsas espalhados no chão e carteiras fora do lugar dificultava o atendimento aos alunos de modo a inibir seu deslocamento com medo de cair ou tropeçar. A falta de interesse e apatia dos alunos que também se dispersavam facilmente dificultavam a regência da estagiária cega, que, precisava de uma interação oral (porém organizada) da turma para conduzir certos conteúdos.

Observou-se ainda dificuldade dos alunos em reportar suas dúvidas a estagiária cega, de modo que, inicialmente, sempre, direcionavam-se à estagiária vidente. Percebeu-se que isso acontecia devido a dois fatores: à falta de confiança no conhecimento da estagiária cega e à certa "vergonha" ou receio de fazê-lo. Com o decorrer do estágio e das aulas, esse problema foi rapidamente solucionado.

No mais, não foi observado diferenças significativa de comportamento dos alunos entre as duas estagiárias (cega e vidente). Brincadeiras próprias da idade, aconteciam independente de quem estivesse à frente da aula (estagiária vidente, cega ou o professor regente). A turma assumiu diante das estagiárias, postura similar de desorganização, desinteresse, apatia ou de animação, comprometimento e empenho nas 
atividades.

\section{Considerações Finais}

A regência durante o estágio supervisionado é pouco tempo para realizar uma análise mais profunda das reais facilidades e dificuldades de um docente cego no exercício da profissão. No entanto, a experiência aqui relatada confirma que, a efetiva inclusão das pessoas com deficiência, vai muito além de sua integração á sociedade. Este é o primeiro passo, representando o início de um processo longo que deve envolver toda a todos. No que tange à formação profissional, ficou claro que a universidade cumpriu seu papel, de modo a, propiciar à aluna cega, todo conhecimento teórico necessário ao exercício profissional. A estagiária cega, está pronta para seguir sua profissão de forma autônoma.

Contudo, percebeu também, que, mesmo com toda a política de inclusão já existente, a escola e os alunos, não estão preparados para receber um docente cego. Esta, envolve a adequação das escolas e da sociedade para receber essas pessoas, de modo a promover a cidadania, como pessoas possuidoras dos mesmos direitos, dentre eles o direito de estudar e trabalhar.

As escolas de modo geral, não possuem infraestrutura necessária para receber alunos e tão pouco profissionais com deficiências. Mesmo o Colégio Aplicação sendo referência no trato aos PCDs, não possui infraestrutura arquitetônica que permita o livre deslocamento (incluindo as salas de aula superlotadas), infraestrutura eletrônica quanto a programas de acessibilidade nos computadores ou materiais didáticos adaptados disponíveis. A estagiária cega apresentou dificuldades na elaboração de aulas e atividades principalmente pela falta de material de base adaptado.

Evidenciou-se também a necessidade de alguém para auxiliar e acompanhar o 
GRADUANDA CEGA NO ESTÁGIO CURRICULAR SUPERVISIONADO

professor cego em determinados momentos como na correção das atividades e avaliações (escritas) ou ainda na utilização do quadro branco ou outros recursos. As políticas de inclusão de alunos com deficiência, não prevê esse apoio e não há legislação que regulamente ou que viabilize uma efetiva inclusão de profissionais, professores cegos, no ambiente escolar.

O que torna a pessoa deficiente, não é a deficiência, mas o ambiente que não está preparado para incluir essas pessoas. Acreditamos que, as escolas que se propõem a serem inclusivas, se constituem os meios mais eficazes de combater atitudes discriminatórias criando-se comunidades acolhedoras. Consequentemente, estes espaços, auxiliam na construção uma sociedade inclusiva garantindo direitos e educação para todos.

\section{Referências}

BLANCO, Maria Rosa. Implicações educativas do aprendizado na diversidade. Gestão em Rede 38, Edição Temática - Como realizar o ensino inclusivo, 2002, pp. 06-11.

BRASIL. Constituição Federal Constituição da República Federativa do Brasil: promulgada em 5 de outubro de 1988. Disponível em:

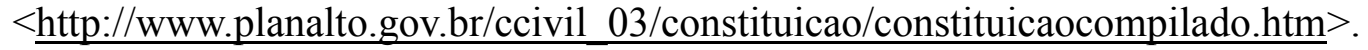

BRASIL. LDB (1996).Lei $N^{\circ}$ 9394, de 20 de dezembro de 1996. Estabelece as diretrizes e bases da educação nacional. Disponível em:

$<\underline{\text { http://www2.camara.leg.br/legin/fed/lei/1996/lei-9394-20-dezembro-1996- }}$ 362578-norma-pl.html>

CONTRERAS, J. Autonomia de professores. São Paulo, Cortez, 2002.

GLAT, Rosana; NOGUEIRA Mario Lucio de Lima. Políticas Educacionais e a formação de professores para a educação Inclusiva no Brasil. Revista Integração, 
Brasília, DF, ano 14, v. 24, p. 22-27, 2002.

MANTOAN, Maria Teresa Eglér Mantoan. Ser ou estar, eis a questão: compreendendo o déficit intelectual. Rio de Janeiro: WVA Editora, 1997.

MARTINS, Rosa. E. M. W.- Um diálogo acerca das experiências dos estagiários no contexto do estágio de docência em geografia. In: GIOIDAUI, Ana Cláudia (Org.). Aprender geografia: a vivência como metodologia. Porto Alegre: Evangraf, 2014.

MAZZOTTA, Marcos José Silveira. Educação especial no brasil: história e políticas públicas. São Paulo: Cortez, 1996.

MAZZOTA, Marcos José Silveira; SOUZA. Sandra, Zákia. Inclusão escolar e educação especial: considerações sobre a política educacional brasileira. Revista Estilos da Clínica, vol.5, n. 9, São Paulo: IPUSP, 2000, pp. 96-108.

PIMENTA, Selma. Garrido., LIMA, M. S. L. Estágio e docência: diferentes concepções. Revista Poíesis Pedagógicas, v. 3, n. 34, p.05-24, 2005.

SANTOS, M. F. P. A relação teoria-prática no estágio supervisionado em Geografia. In: CASTROGIOVANNI, Antônio Carlos Castrogiovanni; TONINI, Ivaine Maria; KAERCHER, Nestor André (Org.). A relação teoria-prática no estágio supervisionado em Geografia. Porto Alegre: Imprensa Livre, 2013, p. 253272.

SASSAKI, Romeu, K. Inclusão: construindo uma sociedade para todos. Rio de Janeiro: WVA, 1997. 
$1 \quad$ O termo cego(a) foi escolhido pela aluna cega para se autodefinir-se. E, tem como objetivo evitar conotações pejorativas que o termo portador de deficiência visual ou deficiente visual possa acarretar. Apesar de a literatura oficial trazer PCDs e este termo ser empregado ao longo do artigo.

2 PCD - Pessoa Com Deficiência - Termo utilizado nos documentos oficiais do governo Brasileiro, para designar as pessoas com algum tipo de deficiência, seja física ou mental.

3 Em vigência atualmente, a LDB sofreu alterações conceituais pela Lei n. ${ }^{\circ} 12796$ de 2013 e possui um capítulo dedicado à educação especial. Este capítulo, no artigo 58, conceitua educação especial, e apresenta a expressão "pessoa com deficiência" em substituição à "portador de deficiência". Já, o art. 59 determina aos sistemas de ensino a obrigatoriedade em garantir medidas que facilitem o aprendizado do estudante por meio de métodos, materiais, currículos e organização que atenda as necessidades do educando.

$4 \quad$ Entre as quais mencionamos: reconhecimento da Libras como língua oficial e sua obrigatoriedade nos cursos de formação docente. Em 2011 o Decreto n7612/2011 institui o Plano Nacional dos Direitos da Pessoa com Deficiência. A lei tem a finalidade de promover, por meio da integração e articulação de políticas, programas e ações, o exercício pleno e equitativo dos direitos das pessoas com deficiência, nos termos da Convenção Internacional sobre os Direitos das Pessoas com Deficiência, garantindo, entre outros, um sistema educacional inclusivo. Em 2012 a Política Nacional de Proteção dos Direitos da Pessoa com Transtorno do espectro autista foi criada pela Lei $n^{\circ} 12.764 / 2012$. Onde vale destacar a vetação de se recusar a matrícula a pessoas com qualquer tipo de deficiência além de estabelecer punições a quem praticar esse ato discriminatório. Aprovação em 2015 da lei № 13.146 do Estatuto da pessoa com deficiência.

5 Mapa base disponibilizado pelo Laboratório de Cartografia Tátil e Escolar (LabTate - UFSC). http://www.labtate.ufsc.br/

recebido em 10 ago. 2017 / aprovado em 14 set. 2018

Para referenciar este texto:

SPRINGER, K. S.; ASSUNÇÃO, S. M.; GONÇALVES, Y. D'A. C. Políticas de Inclusão e a realidade profissional: a experiência de uma graduanda cega no Estágio Curricular

Supervisionado. Cadernos de Pós-graduação, São Paulo, v. 17, n.2, p. 223-238, jul./dez. 2018. Disponível em: <https://doi.org/10.5585/cpg.v17n2.7667> 


\title{
EDUCAÇão INCLUSIVA, OS DESAFIOS PARA SUA EFETIVAÇÃo
}

\author{
INCLUSIVE EDUCATION, THE CHALLENGES FOR THEIR
}

\author{
EFFECTIVENESS
}

\author{
Carla Campos de Oliveira Almeida \\ Mestra em Educação pela Universidade Nove de Julho. Orientadora Pedagógica da \\ Educação Especial da Prefeitura Municipal de Extrema. Extrema - MG - Brasil \\ kalukampos@bol.com.br
}

\begin{abstract}
Resumo: As políticas públicas educacionais no Brasil vêm se modificando ao longo das últimas décadas, na busca de assegurar cada vez mais os direitos das pessoas com deficiência, isto é, dos alunos com necessidades educacionais especiais (NEE). Nesta trajetória de grandes conquistas, principalmente referente às legislações, nos deparamos cada vez mais com os desafios das implementações previstas nas mesmas, sejam elas, a formação docente, adaptação curricular, espaços escolares adaptados etc. Neste sentido, o presente artigo propõe uma leitura do que é proposto na teoria e o que realmente acontece na prática e no dia a dia escolar, seus pontos e contrapontos. Pois, visa à reflexão de possíveis caminhos para a efetivação de uma educação verdadeiramente inclusiva.

Palavras-chave: Educação inclusiva. Desafios. Legislações. Alunos com necessidades educacionais especiais (NEE).

Abstract : Public educational policies in Brazil have been changing over the last decades, in the search to ensure more and more the rights of people with disabilities, that is, of students with special educational needs (SEN). In this trajectory of great achievements, mainly referring to the legislations, we are increasingly faced with the challenges of the implementations envisaged in them, be they teacher training, curricular adaptation, adapted school spaces, etc. In this sense, the present article proposes a reading of what is proposed in theory and what really happens in practice and in the day to day school, its points and counterpoints. For, it aims at the reflection of possible ways for the realization of a truly inclusive education.
\end{abstract}

Cadernos de Pós-graduação, São Paulo, v. 17, n. 2, p. 239-249, jul./dez. 2018. 
Key-words: Inclusive education. Challenges. Legislation. Students with special educational needs (SEN).

\section{Introdução}

s políticas públicas ao longo dos últimos anos têm cada vez mais enfati-
zado os direitos da pessoa com deficiência, principalmente no âmbito da educação.

A escola inclusiva brasileira tem sólidas fundações, na lei, no vanguardismo dos que se dispuseram expandi-la, verdadeiramente imbuídos do compromisso de transformá-la, para se adequar ao nosso tempo. Eles estão se multiplicando e surpreendendo, demonstrando a força desta ideia poderosa - que depende de uma expansão rápida dos projetos verdadeiramente imbuídos do compromisso de transformar a escola comum para se adequar aos novos tempos (MANTOAN, 2015, p. 36).

A ideia de uma educação efetivamente inclusiva impulsionou, nas últimas décadas, significativas mudanças na educação e orientou a transformação nos sistemas de ensino no Brasil.

As mudanças ocorridas nos sistemas de ensino brasileiro em prol de uma educação inclusiva precedem da somatória de esforços que resultaram em grandes conquistas. Tais conquistas se materializaram ao longo de décadas em formas de leis, decretos, portarias e resoluções, que embasam a Política de Educação Inclusiva no Brasil. Para melhor elucidar parte desta trajetória histórica e das mudanças ocorridas, até a chegada da proposta de consolidação de educação na perspectiva inclusiva, analisemos a tabela a seguir: 


\begin{tabular}{|c|c|}
\hline Ano & Lei \\
\hline 1961 & Lei de Diretrizes e Bases da Educação Nacional - Lei no 4.024/61 \\
\hline 1971 & Lei de Diretrizes e Bases da Educação Nacional - Lei no 5.692/71 \\
\hline 1988 & Constituição da República Federativa do Brasil de 1988. \\
\hline 1989 & Lei $n^{\circ} 7.853 / 89$. \\
\hline 1990 & Estatuto da Criança e do Adolescente - Lei no. 8.069/90. \\
\hline 1990 & Declaração Mundial de Educação para Todos. \\
\hline 1994 & Declaração de Salamanca. \\
\hline 1996 & Lei de Diretrizes e Bases da Educação Nacional - Lei no 9.394/96. \\
\hline 1999 & Decreto $\mathrm{n}^{\circ} 3.298$ que regulamenta a Lei $\mathrm{n}^{\circ} 7.853 / 89$. \\
\hline 2001 & $\begin{array}{l}\text { Diretrizes Nacionais para a Educação Especial na Educação Básica (Resolução CNE/CEB no } \\
\qquad 2 / 2001) .\end{array}$ \\
\hline 2001 & Plano Nacional de Educação - PNE, Lei no 10.172/2001. \\
\hline 2001 & Convenção da Guatemala (1999), promulgada no Brasil pelo Decreto no 3.956/2001. \\
\hline 2002 & Resolução CNE/CP n¹/2002. \\
\hline 2002 & Lei n ${ }^{\circ} 10.436 / 02$. \\
\hline 2004 & Decreto $n^{\circ} 5.296 / 04$ \\
\hline 2005 & Decreto $\mathrm{n}^{\circ} 5.626 / 05$. \\
\hline 2006 & Plano Nacional de Educação em Direitos Humanos. \\
\hline 2007 & Plano de Desenvolvimento da Educação - PDE. \\
\hline 2007 & Decreto $n^{\circ} 6.094 / 07$ \\
\hline 2008 & Política Nacional de Educação Especial na Perspectiva da Educação Inclusiva. \\
\hline 2008 & Decreto $\mathrm{n}^{\circ} 6.571$. \\
\hline 2009 & Convenção sobre os Direitos das Pessoas com Deficiência. \\
\hline 2009 & Decreto $\mathrm{n}^{\circ} 6.949$. \\
\hline 2009 & Resolução No. 4 CNE/CEB. \\
\hline 2011 & Plano Nacional de Educação (PNE - 2011 - 2020) - Projeto de Lei. \\
\hline 2012 & Lei $\mathrm{n}^{\circ} 12.764$. \\
\hline 2014 & LEI N ${ }^{\circ} 13.005$, DE 25 DE JUNHO DE 2014. \\
\hline 2015 & $\begin{array}{l}\text { Lei n }{ }^{\circ} \text { 13.416/2015, que institui a Lei Brasileira de Inclusão da Pessoa com Deficiência, conhecida } \\
\text { como Estatuto da Pessoa com Deficiência. }\end{array}$ \\
\hline 2016 & A Consolidação Escolar da Inclusão no Brasil 2003 a 2016. \\
\hline
\end{tabular}

Fonte: elaborada pela autora (2017). 
Dentre as inúmeras legislações citadas e organizadas cronologicamente na tabela anterior que amparam a pessoa com deficiência no âmbito educacional, foram elencadas algumas, para fundamentar o presente artigo.

Em 1961, o atendimento educacional às pessoas com deficiência passa a ser fundamentado pelas disposições da Lei de Diretrizes e Bases da Educação Nacional Lei n ${ }^{\circ}$ 4.024/61, que aponta o direito dos “excepcionais” à educação, preferencialmente dentro do sistema geral de ensino.

A Lei $\mathrm{n}^{\circ}$ 5.692/71, que altera a LDBEN de 1961, ao definir "tratamento especial” para os estudantes com "deficiências físicas, mentais, os que se encontram em atraso considerável quanto à idade regular de matrícula e os superdotados", não promove a organização de um sistema de ensino capaz de atender aos estudantes com deficiência, transtornos globais do desenvolvimento e altas habilidades/superdotação e acaba reforçando o encaminhamento dos estudantes para as classes e escolas especiais.

Em 1973, o MEC cria o Centro Nacional de Educação Especial (CENESP), responsável pela gerência da educação especial no Brasil, que, sob a égide integracionista, impulsionou ações educacionais voltadas às pessoas com deficiência e às pessoas com superdotação, mas ainda configuradas por campanhas assistenciais e iniciativas isoladas do Estado.

Nesse período, não se efetiva uma política pública de acesso universal à educação, permanecendo a concepção de "políticas especiais" para tratar da educação de estudantes com deficiência. No que se refere aos estudantes com superdotação, apesar do acesso ao ensino regular, não é organizado um atendimento especializado que considere as suas singularidades de aprendizagem.

A Constituição Federal de 1988 traz como um dos seus objetivos fundamentais "promover o bem de todos, sem preconceitos de origem, raça, sexo, cor, idade e 
quaisquer outras formas de discriminação" (artigo $3^{\circ}$, inciso IV). Define, no artigo 205, a educação como um direito de todos, garantindo o pleno desenvolvimento da pessoa, o exercício da cidadania e a qualificação para o trabalho. No seu artigo 206, inciso I, estabelece a "igualdade de condições de acesso e permanência na escola" como um dos princípios para o ensino e garante como dever do Estado, a oferta do atendimento educacional especializado, preferencialmente na rede regular de ensino (artigo 208).

A Conferência Mundial de Educação para Todos, Jomtien/1990, chama a atenção para os altos índices de crianças, adolescentes e jovens sem escolarização, tendo como objetivo promover transformações nos sistemas de ensino para assegurar o acesso e a permanência de todos na escola.

Para o alcance das metas de educação para todos, a Conferência Mundial de Necessidades Educativas Especiais: Acesso e Qualidade, realizada pela UNESCO em 1994, propõe aprofundar a discussão, problematizando as causas da exclusão escolar. A partir desta reflexão acerca das práticas educacionais que resultam na desigualdade social de diversos grupos, o documento Declaração de Salamanca e Linha de Ação sobre Necessidades Educativas Especiais proclama que as escolas comuns representam o meio mais eficaz para combater as atitudes discriminatórias, e que estudantes com deficiência, transtornos e altas habilidades/superdotação devem ter acesso à escola regular, tendo como princípio orientador que "as escolas deveriam acomodar todas as crianças independentemente de suas condições físicas, intelectuais, sociais, emocionais, linguísticas ou outras” (BRASIL, 2007).

Considerando que a educação constitui-se em direito humano fundamental, incondicional e indisponível, assegurado no ordenamento jurídico brasileiro e sua efetivação deve ser cumprida sem distinção, em todos os níveis, etapas e modalidades de ensino, cumpre destacar que a Lei no 13.416/2015, que institui a Lei Brasileira de In- 
clusão da Pessoa com Deficiência, conhecida como Estatuto da Pessoa com Deficiência, sistematizou dispositivos relativos ao direito das pessoas com deficiência à educação, constantes da Convenção sobre os Direitos das Pessoas com Deficiência - CDPD, do Estatuto da Criança e do Adolescente - ECA e da Lei $n^{\circ}$ 13005/2014, que institui o Plano Nacional de Educação (PNE), assim como, especificou medidas contidas em Decretos Federais, Notas Técnicas emitidas pelo Ministério da Educação e em Resoluções publicadas pelo Conselho Nacional de Educação, que fazem parte do processo de implementação da Política Nacional de Educação Especial na Perspectiva da Educação Inclusiva, elaborada à luz do artigo 24 da Convenção sobre os Direitos das Pessoas com Deficiência - ONU/2006.

Neste sentido, a atual Política Nacional de Educação Especial na Perspectiva da Educação Inclusiva tem como objetivo o acesso, a participação e a aprendizagem dos estudantes com deficiência, transtornos globais do desenvolvimento e altas habilidades/superdotação nas escolas comuns.

No entanto, mesmo com uma perspectiva conceitual que aponte para a organização de sistemas educacionais inclusivos, que garanta o acesso de todos os estudantes e os apoios necessários para sua participação e aprendizagem, as políticas implementadas pelos sistemas de ensino, num contexto geral, ainda não alcançaram esse objetivo. Pois, segundo a orientação do PNE (2014) aos sistemas de ensino, para promover respostas às necessidades educacionais, deve ser garantido ao estudante com NEE:

a) Transversalidade da educação especial desde a educação infantil até a educação superior.

Subentende-se como um possível caminho de promover a transversalidade da educação especial seja a adaptação curricular, para os alunos com NEE, isto é, o Plano de Desenvolvimento Individual do Aluno (PDI), previsto no artigo 59 da Lei de Diretrizes e Bases da Educação Nacional (LDBEN, Lei no 9.394/96), "preconiza que os 
sistemas de ensino devem assegurar aos alunos currículo, métodos, recursos e organização específicos para atender às suas necessidades”. E está também, assegurado no art. $7^{\circ}$ da resolução das normas sobre a Educação Especial na Educação Básica, no Sistema Estadual de Ensino de Minas Gerais:

Art. $7^{\circ}$ - Compete às instituições de ensino para oferta da educação especial: identificar e elaborar recursos pedagógicos, produzir e organizar serviços de acessibilidade e estratégias considerando as necessidades específicas dos alunos; elaborar e aplicar o PDI, visando avaliar as condições e necessidades dos alunos (MINAS GERAIS, 2013).

O PDI é um instrumental que viabiliza e norteia o trabalho docente, pois oportuniza o professor a pensar e a registrar os conteúdos e estratégias a serem trabalhados com os alunos com necessidade educacional especial (NEE), e assim acompanhar os possíveis avanços dos alunos, além de possibilitar a reflexão sobre sua prática docente.

Mesmo previsto há mais de 21 anos no artigo 59 da LDB, o PDI continua a ser um instrumental teórico, pouco conhecido na prática docente e consequentemente não assegurando os direitos dos alunos com NEE.

b) Atendimento educacional especializado (AEE);

De acordo com a resolução do CNE (2009) no artigo 5º AEE é realizado prioritariamente na sala de recursos multifuncionais da própria escola ou de outra escola, no turno inverso da escolarização, não sendo substitutivo às classes comuns. A elaboração e execução do Plano de AEE são de competência dos professores que atuam nas salas de recursos multifuncionais em articulação com os demais professores do ensino comum, com a participação da família e em interface com os demais serviços setoriais.

c) Continuidade da escolarização nos níveis mais elevados do ensino; 
A “educação é direito inalienável de todos os seres humanos sem distinção de qualquer natureza", bem como a educação inclusiva respaldado por novos marcos legais, políticos e pedagógicos, visam assegurar cada vez mais o direito a escolarização formal nas turmas comuns no ensino regular, isto é, da educação infantil ao ensino superior. De modo a ofertar aos alunos com NEE o apoio necessário que maximize o seu desenvolvimento acadêmico, seja através de um profissional de apoio que o auxilie e/ou através de adaptações curriculares segundo suas necessidades. A finalidade da educação inclusiva é superar o modelo de deficiência visto por muito tempo como invalidez, e promover uma educação pautada no respeito, na identidade e na autonomia, cuja intencionalidade é assegurar a igualdade de oportunidades.

d) Formação de professores para o atendimento educacional especializado, demais profissionais da educação para a inclusão escolar;

O professor, antes de ingressar na ação efetiva da docência, não imagina os inúmeros desafios que fazem parte do ofício de ensinar/educar. Ao iniciar seu trabalho nas escolas, o medo do novo, a insegurança por não saber o que fazer, acaba levando os professores a direcionarem seu trabalho para alunos que melhor possam responder ao seu ensino e apresentar melhores desempenhos nas aprendizagens. Essa questão ainda está presente nas salas de aula atualmente, pois é mais fácil investir onde se vê retorno. Esta maneira de pensar e de sentir, afeta de maneira ainda mais séria, os docentes que se destinam, ou são destinados ao trabalho com alunos com necessidades educacionais especiais (NEE).

Para tanto, um possível caminho para se avaliar alunos com NEE deve partir da premissa e da clareza por parte do professor de que somos indivíduos únicos e singulares, por esse motivo não deve haver intenção de comparação entre os alunos, mas a elaboração e a aplicação da avaliação devem basear-se no potencial e respeito. Por esse motivo é necessário que o professor tenha constituído vínculo com o aluno, tenha 
trabalhado de maneira flexibilizada, as estratégias e conteúdos, se necessário, de modo á respeitar o tempo e ritmo do mesmo.

Alunos que apresentam dificuldades de aprendizagens e, principalmente alunos laudados como tendo alguma deficiência, considerados com NEE, são vistos como incógnitas. Geralmente sabe-se o diagnóstico, mas o prognóstico é imprevisível, pois não há receitas, embora haja muitas informações referentes às características da deficiência e possíveis comprometimentos cognitivos, não há certezas sobre possíveis avanços nas aprendizagens. O tema da inclusão está em evidência, nesse momento, mas, muitas ações dão a impressão que estamos vivendo a exclusão.

e) Participação da família e da comunidade;

A família é peça fundamental no processo ensino/aprendizagem do aluno com NEE, além de ter o direito e o dever de acompanhar a vida acadêmica de seu filho, sendo assim, devem ser participados e estar cientes e envolvidos em todo trabalho, a ser, e desenvolvido na escola, e comunidade escolar.

f) Acessibilidade urbanística, arquitetônica, nos mobiliários e equipamentos, nos transportes, na comunicação e informação;

Pauta-se no direito de ir e vir com segurança e autonomia de acordo com o disposto no Decreto n ${ }^{\circ}$ 5.296/2004, como também no artigo 9 da Convenção sobre os Direitos das Pessoas com Deficiência, independentemente da matrícula de estudantes com deficiência na instituição de ensino.

g) Articulação intersetorial na implementação das políticas públicas;

Sendo um possível caminho de viabilizar, assegurar os direitos e auxiliar a pessoa com deficiência, principalmente a classe menos favorecida, não somente na educação, como também na saúde, moradia, trabalho, esporte e lazer, condições básicas e essenciais para que a mesma possa gozar de uma vida digna e plena. 


\section{Considerações Finais}

Por muito tempo perdurou o entendimento de que a educação especial, organizada de forma paralela à educação comum, seria a forma mais apropriada para o atendimento de alunos que apresentavam deficiência, transtornos, superdotação/altas habilidades, alunos com necessidade educacional especial (NEE), e que não se adequassem à estrutura rígida dos sistemas de ensino. Esta concepção foi mudando ao longo dos anos. De acordo com a evolução dos modelos de interpretação da deficiência, é cada vez mais exigido que seja assegurado às pessoas com deficiência o direito à educação em ambientes escolares inclusivos.

Após mais de duas décadas continuamos a engatinhar na compreensão das mudanças referentes aos entendimentos e práticas relacionadas à educação desses alunos. Ocorreram, por certo avanços, mas são muito pequenos diante das necessidades de muitas mudanças que os estudos recentes indicam.

É fato que a formação do professor interfere no ensino e no processo de aprendizagens dos alunos, positiva ou negativamente, e que a avaliação serve como instrumento dinâmico e termômetro referente às práticas pedagógicas.

Então, o que me parece, é que quando estamos abertos a acolher e a respeitar as diferenças, damos um primeiro passo. $\mathrm{O}$ passo seguinte acontece, quando na percepção da singularidade do aluno com necessidade educacional especial (NEE) o foco não se faz na deficiência e sim no seu potencial.

Contudo, os sistemas de ensino devem organizar as condições de acesso aos espaços, aos recursos pedagógicos e à comunicação que favoreçam a promoção da aprendizagem e a valorização das diferenças, de forma a atender as necessidades educacionais de todos os estudantes. 


\section{Referências}

BRASIL. Ministério da Educação. Comitê Nacional de Educação em Direitos Humanos. Plano Nacional de Educação em Direitos Humanos. Brasília: Secretaria Especial dos Direitos Humanos, Ministério da Educação, Ministério da Justiça, UNESCO, 2007.

MANTOAN, Maria Teresa Eglér. O que é? Por quê? Como fazer? São Paulo, SP: Summus Editorial, 2015.

MINAS GERAIS. Conselho Estadual de Educação. Resolução n 460, de 12 de dezembro de 2013. Consolida normas sobre a Educação Especial na Educação Básica no Sistema Estadual de Ensino de Minas Gerais e dá outras providências. Belo Horizonte, 2013.

recebido em 20 ago. 2017 / aprovado em 17 set. 2018

Para referenciar este texto:

ALMEIDA, C. C. O. Educação inclusiva, os desafios para sua efetivação. Cadernos de Pós-graduação, São Paulo, v. 17, n.2, p. 239-249, jul./dez. 2018. Disponível em: $<$ https://doi.org/10.5585/cpg.v17n2.7716>. 
Resenhas Reviews 


\section{Temas Fundamentais na Escola da Infância, de Ligia de Carvalho Abões Vercelli; Cristiano Rogério Alcântara (org).} Jundiaí, São Paulo: Paco, 2017. 148 p.

Simone Eliane dos Santos Pessanha Mestranda do Programa de Gestão e Práticas Educacionais da Universidade Nove de Julho. São Paulo - SP - Brasil simone.leozinho@gmail.com

presente obra pertence a série Práticas Pedagógicas e a Formação Con-
tinuada na Escola da Infância, organizada por Ligia de Carvalho Abões Vercelli e Cristiano Rogério Alcântara. Vercelli é doutora e mestre em educação, graduada em Psicologia e em Pedagogia, Docente do curso de Pedagogia e do Programa de Mestrado em Gestão e Práticas Educacionais (Progepe) na Universidade nove de Julho (Uninove). Alcântara é doutor em Língua Portuguesa, mestre em Ciência da Informação, Pedagogo, formado em Letras e Literatura brasileira e portuguesa. Atualmente, atua como Diretor Regional da Educação Infantil do Município de São Paulo.

A série é composta por três volumes, sendo que, cada um deles, apresenta resultados de pesquisas de mestrado concluída ou em andamento, além de relatos de práticas de professores/as que lecionam em instituições de educação básica das redes pública, municipal e estadual da grande São Paulo e do ABC. Os títulos dos volumes são os seguintes: Práticas Pedagógicas e a Formação Continuada na Educação Infantil

Cadernos de Pós-graduação, São Paulo, v. 17, n. 2, p. 251-257, jul./dez. 2018. 
Temas Fundamentais na Escola da Infância, de Ligia de Carvalho Abões VERCELLI; CRISTIANO Rogério AlCÂNTARA (ORG)

I (vol. 1), Práticas Pedagógicas e a Formação Continuada na Educação Infantil II (vol.

2) e Temas Fundamentais na Escola da Infância (vol. 3).

O volume 3, que ora resenhamos, denomina-se Temas Fundamentais na Escola da Infância, é composto por oito capítulos, cada um deles escrito por diferentes autores. Tratam-se de textos que discutem a concepção de criança que fundamenta o trabalho pedagógico, onde a criança é vista como um ser capaz de construir conhecimentos e cultura, reafirmando as práticas pedagógicas que são efetivadas nas unidades educativas nas quais os autores atuam.

$\mathrm{Na}$ apresentação, Vercelli e Alcântara ressaltam que os textos são fruto de discussões ocorridas no Grupo de Pesquisa em Educação Infantil e Formação de Professores (Grupeiforp), pertencente ao Programa de Mestrado em Gestão e Práticas Educacionais da Universidade Nove de Julho (Progepe/Uninove).

No prefácio, a Professora Dra. Patricia Vasconcelos Almeida, docente da Universidade Federal de Lavras, ressalta a necessidade de publicações com temáticas que tratem sobre a formação dos professores da educação infantil, e assim, faz uma paráfrase com uma história do escritor uruguaio Eduardo Galeano que se chama "A função da arte", comparando os conhecimentos que as crianças podem descobrir no universo escolar e com o cotidiano da escola [...] “já que, muitas vezes, diante da imensidão do conhecimento, o aluno, não com essas palavras, mas por muitas vez es, pede ao professor: “- Me ajuda a olhar!”. [...] (ALMEIDA, 2017, p. 9)

O primeiro capítulo, intitulado "Projeto Amigos da Natureza: uma relação entre creche e comunidade no município de Santo André", Ligia de Carvalho Abões Vercelli e Talita Penelope Rodrigues da Silva, discutem a parceria estabelecida entre escola e comunidade, como primordial para uma educação de qualidade. As autoras ressaltam que a responsabilidade social é fundamental e contribui para a melhoria da qualidade 
de vida da sociedade, por isso, deve estar de acordo com as necessidades da comunidade. As autoras relatam que houve a caracterização da comunidade, para que pudesse ser analisada as práticas da creche para que o Projeto Político Pedagógico (PPP) pudesse ser construído, identificando os problemas com relação ao local por onde as crianças transitam. Uma das ações efetivas da creche foi o Projeto Amigos da Natureza, que de forma lúdica, os educadores proporcionaram ações de conscientização sobre o problema do lixo na comunidade. Vercelli e Silva, apontam que a comunidade local e a creche se mobilizaram e houve conscientização como possibilidade de reflexão sobre o meio ambiente e reciclagem, as ruas da comunidade permanecem mais limpas e a escola está preservada e é motivo de orgulho para o entorno escolar.

Eunice Ramos de Carvalho Fernandes, no segundo capítulo intitulado "Educação infantil: a construção do número pela criança”, apresenta as formas e as atividades que proporcionam as crianças a obtenção da construção do número. A autora aponta de forma muito positiva, que a construção das operações e do conceito de número se inicia desde a mais tenra infância e está inserida na escola e em todo o cotidiano da criança. Para compreender os números, as crianças vão adquirindo o entendimento necessário e passam a perceber a importância exercida pelos números em seu meio social, e para isso, são necessários estímulos. Fernandes destaca que, para a construção dos conhecimentos matemáticos por parte da criança, as professoras podem propor atividades variadas que despertem a imaginação e o cognitivo, dessa forma, o aprendizado e a construção do pensamento lógico matemático será apreendido de forma efetiva.

No terceiro capítulo "A leitura na educação infantil sob o olhar freiriano: uma análise crítica da realidade", Thiago Valim Oliveira, analisa a alfabetização precoce que tem ocorrido em muitas escolas de crianças pequenas, oferece sugestões de atividades lúdicas para serem trabalhadas na escola. $\mathrm{O}$ autor se apoia em algumas leis para apre- 
Temas Fundamentais na Escola da Infância, de Ligia de Carvalho AbÕes VERCELLi; CRISTIANO Rogério ALCÂNTARA (ORG)

sentar conceitos importantes da educação infantil, como por exemplo, o desenvolvimento integral da criança. Oliveira, também aborda que o conhecimento de mundo que a criança carrega para a escola precisa ser acolhido pelo educador para que seu aprendizado seja efetivo e significativo; também aborda o conceito de educação bancária que está ultrapassado, mas ainda permanece em algumas instituições. Desta forma, o autor destaca que a brincadeira é importante, visto que possibilita o aprender a ler nas situações interativas do contexto social.

O capítulo quatro, intitulado "Nem feio nem bonito: o olhar do professor para as produções infantis", Angélica de Almeida Merli, apresenta a relevância da coordenação pedagógica no trabalho dos fazeres docentes e sua contribuição para a arte na Educação Infantil com possibilidades formativas. A autora relata uma experiência vivenciada por ela junto a formação docente no trabalho com a expressão artística, uma vez que declara não ter dotes artísticos, mas que a formação oferecida à ela mudou o seu olhar para a arte e possibilitou propostas inusitadas para o trabalho com as crianças. No decorrer do texto a autora faz seu relato sobre o curso que participou com duas professoras da Escola Municipal de Educação Infantil (Emei) na qual era coordenadora pedagógica, deixando o julgamento de feio e/ou bonito de lado, para que pudessem aguçar o olhar das crianças com o novo, proporcionando a imaginação e a criatividade. Merli, precisou repensar a sua própria prática, porém, isso também envolvia o pensar a prática das professoras para redimensionar suas ações. Ela declara que esse processo foi fundamental para sua formação, visto que, foi preciso oferecer às crianças materiais e propostas diversas, possibilitando o criar e recriar das fantasias infantis, dessa forma, as professoras que se propuseram a oferecer novas propostas às suas turmas, também aprenderam por meio de métodos diferenciados e de novos olhares.

O quinto capítulo intitulado "Educação infantil: relações étnico-raciais e formação docente", Moacir Silva de Castro, aborda algumas concepções de criança e infância, 
para que possa melhor compreender a criança pequena na sociedade e no contexto escolar, por isso, o trabalho pedagógico da escola da infância tem importância educativa nas relações etnicorraciais. O autor aborda a categoria de criança ou infância que acontecem nas diversas sociedades e isso, nos leva a refletir as diferenças que são encontradas nos diversos contextos históricos, e que, dependem das relações políticas, cultural e econômica de cada povo, em um determinado tempo e espaço. Castro também ressalta que o docente da educação infantil, escolas e comunidade escolar, precisam de formação para tratar das questões referentes a diversidade étnica, porque a docência é uma ação educativa e é constituída mediante relações sociais, é preciso que os profissionais garantam os direitos das crianças negras previsto em lei para que estes se efetivem, assegurando às crianças o pleno desenvolvimento. Ressalta o artigo $5^{\circ}$ das Diretrizes Curriculares, a Lei 10.639/2003 e 11.645/2008, Plano Nacional de Educação (PNE 2014-2024), Plano Nacional de Educação em Direitos Humanos (PNEDH), são excelentes exemplos para uma educação de qualidade, que somente é significativa quando a criança sente motivação e interesse, visto que o conteúdo é relevante e mediante o contexto da criança, ela aprende e apreende, e atinge os objetivos qualitativos da educação.

No sexto capítulo "Discutindo a construção de valores na Educação Infantil”, Sandra Helena Loureiro Hoyler e Silvana Monteiro Gondim, discutem a construção de valores na educação infantil e como podem ser trabalhados em atividades de rodas de conversa, brincadeiras e contação de histórias. As autoras abordam a construção dos valores pautadas em Mario Sergio Cortella e outros educadores. Hoyler e Gondim, descrevem que a construção dos valores das crianças precisa ser desenvolvida desde cedo pelos pais, família e escola, dessa forma, a criança aprenderá a ser responsável pelos seus comportamentos e ações. Elas se apoiam em Freire para abordar a educação pautada no respeito, por ser um princípio básico para a convivência do ser humano em 
sociedade; professores e crianças devem aprender uns com os outros dentro de princípios éticos e dialógicos, possibilitando a troca de ideias e informações.

"Aulas de trabalho pedagógico coletivo: ações contra a mediocridade", é o título do capítulo sete, escrito por Amanda Maria Franco Liberato e Sueli Julioti. As autoras abordam a questão da mediocridade em espaços que são destinados à formação continuada, e que acabam sendo subutilizados para recados burocráticos. As autoras fazem uma apresentação sobre a concepção de Aulas de Trabalho Pedagógico Coletivo (ATPC), que são horas destinadas às aulas propriamente ditas que devem equilibrar o trabalho dos professores dentro da carga horária, para a correção dos trabalhos e aperfeiçoamento dos docentes. Liberato e Julioti ressaltam que o espaço fundamental de formação do professor está sendo reduzido e desmotivando o educador, visto que, a ênfase dessas reuniões acaba recaindo para repasse de orientações desnecessárias que não tem relação com o cotidiano e aperfeiçoamento do professor, essas orientações muitas vezes advindas das Diretorias de Ensino, são repassadas pelos coordenadores como recados.

No último capítulo "Tecnologias da informação e da comunicação: o aplicativo Scratch em foco”, Dalva Célia Henriques Rocha Guazzelli, Élida Ferrari Penhalver e Lucimara de Souza Teixeira, apresentam o aplicativo Scratch, e apontam como ele pode colaborar no desenvolvimento do raciocínio lógico de crianças do $5^{\circ}$ ano do ensino fundamental; propõem diálogos com o uso de metodologias aliadas à tecnologia, proporcionando competências relevantes para o desenvolvimento da criança. De forma criativa e mediante a realidade da criança, as autoras fazem uso do Scratch, como forma de desenvolver a lógica e o raciocínio na educação básica. As crianças aprendem a pensar criticamente e também trabalhar colaborativamente. Guazzelli, Penhalver e Teixeira, tratam a questão das tecnologias da informação na educação de forma criativa, pois 
mostram que as crianças precisam de experiências novas para sentirem motivação para aprender, e o aplicativo "Scratch" possibilita essas descobertas.

A obra apresentada tem grande relevância e interessa não somente a professores, mas a todos aqueles que pesquisam sobre temas como práticas pedagógicas e formação continuada para professores da escola da infância. 


\section{Plano Nacional de Educação: diversos olhares, de Andréia} Nunes Militão e Fabio Perboni.

Curitiba, PR: CRV, 2017. 232p.

\section{Sueli do Nascimento}

Mestranda do programa de Pós-Graduação em Educação pela Universidade Estadual de Mato Grosso do Sul - Paranaíba- MS - Brasil sueli.unisalesiano@gmail.com

Welcianne Iris de Queiroz Mestranda do programa de Pós-Graduação em Educação pela Universidade Estadual de Mato Grosso do Sul - Paranaíba- MS - Brasil welqueiroz@gmail.com

obra, organizada em formato de coletânea, fomenta discussões acerca
do novo Plano Nacional de Educação (PNE), resultado de dois ciclos de debates, envolvendo a Universidade Federal da Grande Dourados (UFGD) e a Universidade Estadual do Mato Grosso do Sul (UEMS).

No prefácio, José Marcelino de Rezende Pinto ressalta que “[...] esse plano reflete, em sua redação, as lutas e contradições que marcaram o seu envio e sua tramitação no parlamento brasileiro", o que estimula a leitura dessa obra.

O primeiro capítulo, “Novo PNE e a revisão do FUNDEB”, de Luiz Araújo, trata da necessidade de redistribuição dos recursos educacionais, antecipando o debate sobre as reformulações do Fundeb.

Em “O Financiamento da Educação Básica no Novo PNE: pontos para o debate”, o autor Silvio Cesar Nunes Militão avalia os principais aspectos do financiamento 
da educação básica desse novo PNE; problematiza também a viabilização das metas propostas. Numa digressão, analisa os governantes desse período e a relação com as metas vetadas que, consequentemente, comprometeram o êxito desse plano (20012010).

Do título "Implicações do Plano Nacional de Educação na responsabilidade educacional", de Danilo Trombetta Neves e Cristiano Amaral Garboggini Di Giorgi, emergem três temas: qualidade da educação, responsabilidade dos agentes públicos e apontamentos do Plano Nacional de Educação, com vistas à Lei de Responsabilidade Educacional, a partir do "cumprimento ao disposto na estratégia da Meta 20 do PNE - LEI n ${ }^{\circ} 7.420 / 2017$.

O capítulo quatro afirma que "atrelar a avaliação à qualidade de ensino sem questionar as modalidades e os sentidos atribuídos contribui para a despolitização da própria avaliação e faz dela muito mais um instrumento de controle do que de qualidade" (p. 78). Subscreve, portanto, o ato de qualificar, classificar e punir; afinal, tanto no PNE I, quanto no PNE II, o importante é avaliar.

No título "Plano Nacional de Educação (2014-2024): uma análise sobre a visibilidade conferida à temática da diversidade”, Marcos Vinicius Francisco, Silvio Cesar Nunes Militão, Andréia Nunes Militão e Fabio Perboni exploram o campo denso da minoria que faz parte da educação brasileira. Afirmam que, apesar de se tratar de um cenário contemporâneo, "os invisíveis" continuam invisíveis, além de ainda mantidas as desigualdades.

No capítulo seis - "A diversidade étnico-racial e o novo Plano Nacional de Educação (2011- 2020): desafios para a pedagogia crítica e decolonial -, Eugenia Portela de Siqueira Marques propõe-se aferir os desafios frente à implementação das políticas educacionais que, pressupõe-se, enfatizam a garantia do direito à diversidade, também 
proposto pelo PNDH por intermédio do Decreto no 1.904, de 13 de maio de 1996, e do Estatuto da Igualdade Racial, Lei no 12.288/2010.

No capítulo sete, Tatiana Pinheiro de Assis Pontes traz discussões acerca da valorização profissional e da formação de professores à luz do PNE. Ressalta que, apesar de a docência exigir formação inicial para seu exercício, de acordo com LDB/1996, esta não é a realidade para todos os professores da educação básica brasileira.

No título “Gestão democrática: novas determinações, velhos dilemas", Andréia Nunes Militão, discute as determinações contidas no PNE (2014-2024), em particular a Meta 19, que versa sobre a gestão democrática. De acordo com a autora, o dispositivo, apesar de trazer algumas mudanças positivas em relação ao PNE (2001-2011), especialmente por incorporar a temática da gestão democrática ao texto da lei, retrocede ao acrescentar elementos vinculados ao desempenho por meio de medidas alcançadas em provas, como igualmente retrocede relativamente aos princípios de mérito, equiparando-se aos princípios de mercado que, por excelência, são regidos por princípios de concorrência, seja pela carteira de clientes, seja pela relação custo-benefício do serviço ofertado.

No capítulo nono, Thaise da Silva analisa diretrizes, metas e estratégias do PNE concernentes à alfabetização. Sinaliza as três diretrizes do art. $2^{\circ}$, que comporão sua análise, a saber, os incisos I, II e III, que tratam, respectivamente, da erradicação do analfabetismo, da universalização do atendimento escolar; [...], da melhoria da qualidade da educação; [...] (BRASIL, 2014, p. 1).

Iara Augusta da Silva, no capítulo dez, sob o título "As Políticas de Educação para o Ensino Médio no Brasil nas últimas décadas do século XX e início do século XXI: o que dizem os documentos e os pesquisadores", problematiza o ensino médio dentro do PNE (2014-2024). Amparada em pesquisas de Rodriguez e Herrán (2000), diz que o processo de globalização e de competição de mercado assinala a necessidade 


\section{Cadernos}

FABIO PERBONI.

Plano Nacional de Educação: Diversos olhares, de Andréia Nunes Militão e

de formar trabalhadores de nível médio, forçando o Estado a gerir políticas educacionais que atendam a essa demanda da sociedade.

A autora Jucirley Cardoso de Jesus Oliveira destaca a necessidade de reflexão e discussão sobre o fato de o Índice de Desenvolvimento da Educação Básica (Ideb) ser o principal indicador de qualidade da educação dentro dos pressupostos da referida meta. Questiona os padrões estabelecidos para a elevação da qualidade da educação, uma vez que não se tem claro a que interesses atendem, nem de que qualidade se fala.

O momento atual é oportuno para buscar a participação da sociedade na mudança na representação social dos professores, pois há espaços, como a Conferência Nacional Popular de Educação (Conape), que cobram do PNE a participação da sociedade civil, principalmente através dos professores que, por serem os atores educacionais, têm voz. Infelizmente, não é raro ouvir, em seus depoimentos e nos de gestores, desconhecerem a importância e, pior, a existência desse espaço. A maioria deles anda tão assoberbada em suas tarefas de rotina que sequer ouviu falar em Conape, e, muito menos, nos princípios que o regem, ou qual seja seu papel dentro dentre desse precioso espaço. A maioria entende que o único lugar de voz de que dispõem são as greves, alijados dos processos que constituem sua profissão.

\section{Referências}

BRASIL. Lei n ${ }^{\circ}$ 13.005, de 25 de junho de 2014. Plano Nacional de Educaşão - 20142024. Disponível em: http://www.planalto.gov.br/ccivil 03/ ato20112014/2014/lei/113005.htm . Acesso em: 13 nov. 2017.

. Diretrizes e Bases da Educação Nacional. Lei no 9.394/ 1996, de 20 de dezembro de 1996. Estabelece as diretrizes e bases da educação nacional. Diário Oficial da União. Brasília, DF, 23 dez. 1996.

NASCIMENTO, S.; QUEIROZ, W. I. 


\section{A educação básica pública tem solução? de Herman J.C. Voorwald}

São Paulo: Unesp, 2017. 117 p.

\section{Carlos Lima Dantas}

Mestrando do Programa de Mestrado em Gestão e Práticas Educacionais da Universidade Nove de Julho. São Paulo - SP - Brasil carloslimadantas@hotmail.com

presente obra destaca-se dentre os aspectos editoriais, pela autoria e re-
tórica relacionada a atuação e formação acadêmica do autor, indo ao encontro das ciências da natureza, gerencialista, lógica e exata.

Para isso, destacadamente relembro que Herman J.C. Voorwald é engenheiro mecânico, mestre e doutor em Engenharia Mecânica. Logo, sem muitas dificuldades, facilmente seria possível afirmar que pouco ou quase nada teríamos a saber daquilo que defronte da sua avaliação sobre a educação e os seus mecanismos pedagógicos que por ora, aprofundaria tal análise sobre esta natureza humana e dialética. A linha de pensamento, naturalmente estaria correta, se não levássemos em consideração um dos cargos mais significativos exercido em sua trajetória profissional: Secretário de Educação do Estado de São Paulo, entre o período sabático da reorganização das escolas, onde na oportunidade, ocorreram as ocupações dos estudantes nas instituições. Diante desta lembrança, a leitura do livro tornou-se cômoda e, principalmente fundamental no propósito de descoberta das motivações e razões que teriam levado o Secretário de Educação - cargo político - dissertar sobre o assunto: educação básica.

Cadernos de Pós-graduação, São Paulo, v. 17, n. 2, p. 263-267, jul./dez. 2018. 
Sem muitos imbróglios, exercido naturalmente pela "mecânica" do autor, o livro divide-se em 5 capítulos, sucintos, apontando as definições históricas e administrativas no papel do estado à frente dos problemas encontrados na educação, desde o permeio das políticas públicas àquilo que contribui de maneira positiva e também negativa aos índices de avaliação deste sistema. Vamos imergir nestes capítulos:

No primeiro denominado Algumas palavras sobre o contexto histórico, o autor traça um panorama histórico, daquilo que foi inerente à concepção da educação, datados pela constituição de 1824, nela situada como elemento aos direitos civis e políticos. Naturalmente neste discorrer, dados, números e estratégias são citados, de modo a fundamentar e aprofundar a análise no contexto científico e qualitativo destes recursos adotados. Os desafios e os índices qualitativos do Sistema de Avaliação de Rendimento Escolar do Estado de São Paulo (Saresp) são notoriamente destacados, tal como a gestão de carreira do profissional de educação.

O segundo capítulo, Politicas públicas e educação - diálogo e compromisso, encaminhase para uma espécie de diário profissional, onde o autor, por vezes, cita sua experiência à frente da Secretaria da Educação. Curiosamente, destaca-se o diálogo daquela oportunidade com os supervisores, diretores, professores, coordenadores de oficinais pedagógicas, professores coordenadores e membros dos quadros de apoio escolar da Secretaria da Educação, mostrando-se presente os anseios e, principalmente as referências deste grupo às pautas relacionadas aos recursos humanos, totalizando $61,8 \%$ das manifestações, sistematizadas pelos 5.389 servidores.

No terceiro capitulo: Reestruturação da Secretaria da Educação do Estado e o Programa Educação: compromisso de São Paulo, a abordagem está voltada na restruturação que ocorreu no sistema educacional no ano de 2012, de modo ambicioso, concebido para delinear de maneira clara os encargos administrativos e para realizar um resgate histórico, traçando um paralelo entre as mudanças socioeconômicas e a política de educação. 
Num sobrevoo pelas políticas educacionais, o autor traz à tona, neste capitulo, as ações governamentais que apontaram para as diretrizes e valores relativos aos processos de formação no âmbito escolar. Neste passeio histórico, destaca-se a ótica observacional da década de 1970 e o surgimento das palavras "eficiência", "controle”, "planejamento" e "avaliação" como definição de metas e mediação de resultados.

Nessa sessão o livro, destaca-se pela extensão de dados e informações administrativas sobre as estratégias e planos traçados pelo Estado para conter a abrasividade na educação e manter de maneira satisfatória, os resultados apontados nos índices e avaliações. Para isso, nota-se a abordagem prescritiva em três níveis lógicos: Controle-padronização, centralização e estruturação, detalhadamente expostos, neste primeiro nível por cincos pilares: 1- Valorizar e investir no desenvolvimento do capital humano da secretaria; 2- Aprimorar as ações e a gestão pedagógica da rede com foco no resultado dos alunos; 3- Expandir e aperfeiçoar a política de educação integral; 4- Viabilizar mecanismos organizacionais e financeiros para operacionalizar o programa; 5- Mobilizar, engajar e responsabilizar a rede, os alunos e a sociedade em torno do processo de viabilização da aprendizagem; devidamente contemplados nestes pilares as nove áreas nas quais foram agrupadas as manifestações dos profissionais da educação discutidas no segundo capítulo, sendo elas: comunicação, formação continuada, gestão de infraestrutura, gestão de recursos humanos, gestão institucional, programas e projetos, gestão de ensino, informação, monitoramento e avaliação, orçamento e finanças.

Quarto capítulo, oportuno, indo ao propósito de identificar os desafios deste sistema, nomeia-se como $O$ desafio da melhoria da qualidade, como não poderia ser diferente de seu título, o autor aprofunda-se na problematização e nos aguilhões expostos do capítulo anterior, onde os dados suspostamente apontam a melhora, segundo a ótica do autor, naquilo que foi traçado como objetivo pelo Estado, dentre os vários aspectos destacados neste fragmento do livro, estão, o ensino integrado, a flexibilização da grade 
e o aumento da carga horária, tal como a concentração das demandas levantadas pelos profissionais da educação pública paulista.

No último capítulo denominado Propostas - apresenta-se como uma espécie de filé do cardápio, prato principal, o caviar do livro. O autor faz um paralelo aos fatores históricos, sobretudo na discrepância social que nos trouxe até a situação existente, usada como escudo por governantes para a implementação de novas, diferentes e ousadas políticas públicas, como mecanismo de transformação. Descreve de maneira dominante, como as universidades públicas paulistas tornaram-se referência nacional e internacional, agindo de maneira independente às ações administrativas por meio do Plano de Desenvolvimento Institucional (PDI). Neste momento do livro, o autor comunica-se de maneira célebre aos pilares discutidos no terceiro capítulo, propondo de maneira pontual as Propostas, tal como o nome do capítulo, aquilo que tivera sido identificado pelo Estado durante sua tratativa de governo, discorrendo numericamente por cada um deles.

A divisão do livro, destaca-se pela a abordagem da reorganização da rede pública estadual, enfatizando as questões: estrutura física, logística e humana (pessoas), no que diz respeito a tal reorganização, o tamanho da escola torna-se o objeto analítico no contexto do autor, principalmente quando tal espaço, mostra-se amplo no sentido espacial, tendo seu uso destinado ao programa de ensino integral.

Entre as Propostas e reflexões do autor a respeito dos pilares e das estratégias expostas ao longo dos capítulos, a última parte do exemplar do material impresso, notadamente reforça a relevância da leitura quanto ao tema, sobretudo do conteúdo do livro e da abordagem cotidiana e trivial no exercício do cargo de secretário ocupado pelo autor durante o processo de coleta e laboratório do tema discutido nas páginas do livro, para isso a imersão nos capítulos remete de maneira clara o cenário atual das 
políticas, e principalmente das práticas educacionais presentes no ambiente escolar, exercido rotineiramente pelos profissionais de educação.

Diante do exposto a leitura da obra, torna-se relevante e principalmente indicada, uma vez que as informações presentes vão ao encontro da complexidade do ambiente administrativo, político e sobretudo participativo da rede, refletindo de maneira natural ao entendimento e aplicabilidade dos recursos financeiros, humanos, institucionais e infraestrutural, vigentes na gestão escolar deste a sua concepção neste modelo gerencialista.

A leitura provoca de maneira natural a questão: seria utópico pensarmos em um sistema de educação pública brasileiro entre os 25 melhores do mundo?

O livro fornecerá as instâncias necessárias para a resposta, reflexão e compreendimento deste horizonte, sob a ótica do autor e Secretário de Educação do Estado de São Paulo. 


\section{A vida cotidiana dos adolescentes em conflito com a lei e o} envolvimento com práticas delitivas, De Neusa Francisca de Jesus.

São Paulo: Expressão \& Arte, 2014. 160 p.

\section{Agnaldo Aparecido Geremias}

Mestrando em Educação pela Universidade Nove de Julho.

São Paulo - SP - Brasi agnaldo.geremias@gmail.com

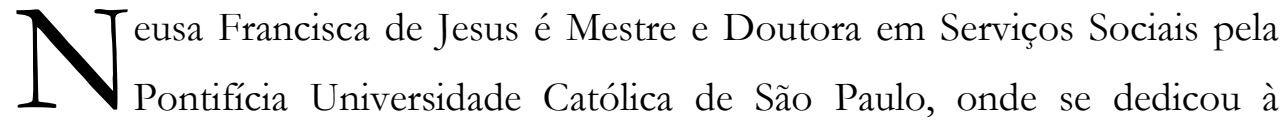
pesquisa acerca do universo da adolescência e juventude, destacadamente os envolvidos com a conflitualidade. Foi componente do corpo docente da Universidade Anhanguera de São Paulo entre os anos de 2007 e 2014, desenvolvendo atividades de ensino e pesquisa no Programa de Mestrado Profissional - Adolescente em Conflito com a Lei; como Coordenadora nos cursos de Especialização Adolescente em Conflito com a Lei e de Gestão de Políticas Públicas Sociais e, na Graduação, nos cursos de Pedagogia e Serviço Social. É pesquisadora do Programa Estadual do Adolescente e da Comissão Científica do Adolescente da Secretaria de Estado da Saúde/SP, do Grupo de Estudos e Pesquisa em Interdisciplinaridade (GEPI - PUC/SP), da Associação Nacional de Direitos Humanos, Pesquisa e Pós-Graduação (ANDHEP) e membro da Associação 

PR ÁTICAS DELITIVAS, DE NEUSA FRANCISCA DE JESUS.

dos Pesquisadores de Núcleos de Estudos e Pesquisas sobre a Criança e o Adolescente (NECA).

A obra A Vida Cotidiana dos Adolescentes em Conflito com a Lei e o envolvimento com práticas delitivas é o resultado da pesquisa realizada pela professora Neusa, especificamente com adolescentes que cometeram atos infracionais e em cumprimento de medida socioeducativa de internação numa unidade da Fundação CASA, instituição responsável pela execução das medidas socioeducativas privativas e restritivas de liberdade no estado de São Paulo. A aludida pesquisa buscou compreender a que esses adolescentes atribuíam o seu envolvimento com a prática delitiva. Para tanto, na primeira parte da obra, a autora discorre inicialmente acerca dos elementos importantes de sua trajetória profissional que a despertaram e a motivaram para tal busca. A seguir, contempla a fundamentação teórica da pesquisa, destacando, em seus dois primeiros subtítulos, os aspectos referentes à problemática e ao processo de construção e realização da pesquisa. Destarte, a autora apresenta, de forma didática e elucidativa, diversas abordagens teóricas sobre os conceitos de criminalidade e crime, apoiando-se no referencial teórico utilizado na investigação, qual seja numa abordagem sócio-histórica. Particularmente neste trecho da obra, a professora Neusa traz à tona reflexões e críticas sobre as concepções de criminalidade e suas relações com a adolescência. Destaca os estereótipos criados sobre esses adolescentes a partir dessas concepções, no decorrer da história, e perfaz um caminho de aprofundamento teórico acerca do fenômeno adolescência e criminalidade, indo desde as raízes da criminologia positivista até as teorias desenvolvimentistas. Destaca ainda as teorias do controle 
social, teoria da escolha racional e teoria do interacionismo simbólico como sendo as mais recentes abordagens utilizadas na interpretação criminológica.

$\mathrm{Na}$ segunda parte são apresentados gráficos contendo dados quantitativos obtidos a partir das entrevistas e relacionados à faixa etária, origem geográfica, procedência, níveis de escolaridade e desempenho escolar, aspectos ligados ao trabalho, ao modelo familiar e, por fim, aspectos sobre o uso de drogas. A partir desses dados, a pesquisadora apresenta suas considerações acerca das representações e significados trazidos pelos entrevistados a respeito da infância, da sua relação com a escola, das configurações e dinâmicas familiares, bem como sobre a forma como os adolescentes percebem o ato infracional e quais os motivos, motivações e conexões com o delito. Assim, a autora descreve as três categorias de análise que embasaram a pesquisa, quais sejam: o envolvimento com a criminalidade ancorado na estrutura social; o envolvimento com a criminalidade ancorado na emoção e o envolvimento com a criminalidade ancorado na representação.

Pautada nas referidas categorias e partindo da transcrição dos conteúdos orais obtidos no decorrer das entrevistas, a professora Neusa passa então a analisar o discurso apresentado pelos adolescentes pesquisados, combinando sua percepção com uma ampla fundamentação teórica, buscando minimizar as questões subjetivas e maximizar o grau de objetividade dos dados qualitativos apurados. Vale destacar que o formato escolhido para a apresentação dos dados permite aliar aspectos tangíveis com percepções por vezes intangíveis, mas que, de alguma forma, revelam objetividade, sobretudo ao serem confrontados com estudos já realizados e que fundamentam as categorias de análise apresentadas pela pesquisadora. Embora no desenvolvimento da pesquisa a professora Neusa não tivesse apresentado a pretensão de traçar possibilidades para a ressocialização dos adolescentes, a autora destaca na sua 
conclusão, a dificuldade de conceber tal perspectiva, reafirmando que o objetivo da investigação era o de analisar as percepções dos adolescentes acerca do envolvimento ilícito.

Por fim, a pesquisadora aponta o caráter heterogêneo do ato infracional, uma vez que os sujeitos envolvidos com a ilicitude o fazem a partir de pontos de vista diversos e salienta, também, os processos de socialização que permeiam a atualidade, os quais, segundo a autora, desempenham importante papel nas escolhas desses meninos, motivando em grande medida o envolvimento com o delito.

A obra de Neusa Francisca de Jesus revela, além da dedicação e preocupação com o processo de construção de conhecimento imbricado nessa temática, o cuidado da autora com a apresentação da realidade dos adolescentes envolvidos com a criminalidade, sem permitir que o seu lugar de observadora e crítica desumanizasse o processo de investigação. A interlocução desenvolvida entre a fala dos adolescentes pesquisados e a análise técnica dos discursos possibilitam perceber o sujeito por trás do texto, proporcionando um movimento dialético que resulta numa síntese, ainda que provisória, vez que trata de processos vivos e que busca, todo tempo, desmistificar a imagem do "menor infrator" construída no desenrolar do processo sócio-histórico brasileiro.

Cabe por fim destacar a relevância da publicação, tendo em vista que esta particular seara do conhecimento é carente de subsídios e embasamentos científicos.

Assim sendo, esse livro merece fazer parte do material de estudos de todos os profissionais e estudantes que lidam, ou pretendem enveredar de forma direta ou 
indireta pelos desafios do enfrentamento e superação do fenômeno adolescência e conflitualidade. 
Formação inicial de professores: da escola normal ao instituto superior de educação - uma abordagem histórica, de Lucilene Pisaneschi

São Paulo: Livro Novo, 2010, 463 ps

Raquel Silva Santos Mestra em Educação pela Universidade Nove de Julho.

São Paulo - SP - Brasil raquel.brutus.silvasantos@gmail.com

obra é resultado da pesquisa de Mestrado em Educação, do ano de
2007, que a autora desenvolveu na Universidade de São Paulo, na busca de respostas às indagações que se fazia desde sua graduação em História no ano de 1997. A estrutura do livro é dinâmica, contendo duas unidades e cada unidade, quatro capítulos.

Quem faz o Prefácio de seu livro é a professora e ex-secretária de educação do estado de São Paulo, Rose Neubauer, que inicia sua apresentação resgatando a história e as experiências vividas com a autora. Neubauer destaca a necessidade de se escrever a própria história, apresentando a obra como uma busca de respostas e de compreensão, pela autora, da própria existência e vivência, da profissão e da vida.

A Apresentação do livro fica por conta de Gisela Wajskop que destaca os pontos principais da obra, fazendo um resgate da história da construção do trabalho de Pisaneschi. Expõe a sua admiração em relação à coragem da autora por resgatar 
a história tão bravamente, sem neutralidades, mas com coerência cientifica e sensibilidade. Também destaca que a obra vai muito além de relato histórico, afirmando que representa uma evidência da problemática da formação inicial docente e dos embates político- ideológicos que perfazem esse campo. Os endereços institucionais de formação docente foram, ao longo do livro, submetidos a uma rigorosa análise investigativa, na tentativa de resgatar o locus e a identidade institucional da formação inicial do professor. Gisela finaliza concluindo que a autora teve audácia, coragem e êxito em trazer à tona as evidências históricas que, até o dado momento, se faziam escassas nos respectivos estudos científicos sobre a temática, tornando-a, assim, uma obra prima.

$\mathrm{Na}$ Introdução ao livro, Pisaneschi nos apresenta um memorial pessoal e profissional em que destaca parte de suas perguntas, enquanto professora de história e geografia, sobre a identidade do professor e a sua formação especifica para lecionar.

A primeira parte da obra, denominada Unidade I: A formação dos professores das series iniciais no âmbito do ensino secundário, a autora fez uma viagem aos primórdios da formação docente no Brasil. Traz o debate em torno das discussões sobre as instituições de formação inicial para professores primários e sua localização institucional no ensino secundário, apresentando o percurso da escola normal, da habilitação ao magistério e do Centros Específicos de Formação e Aperfeiçoamento do Magistério (CEFAM). Demonstra, empiricamente, os processos de continuidades e descontinuidades no âmbito das políticas educacionais e suas implicações nos caminhos da formação inicial de professores.

Em seguida, desenvolve as temáticas discutidas no texto. Em A trajetória da formação do professor primário entre o Império e a Primeira República traça um panorama das instituições de formação desde a colonização, contextualizando os 
primórdios da escola normal até a sua consolidação como símbolo da República e endereço institucional de formação de professores.

Segue com Caminhos e descaminhos da escola normal, no qual aborda a criação do Ministério da Educação e Saúde (1931) como estratégia político-ideológica do governo Vargas em meio a um cenário de intensas disputas entre os que defendiam as ideias da Escola Nova e os chamados conservadores. Faz uma reflexão acerca do papel do Instituto Caetano de Campos como locus de formação para professores, destacando os avanços e as limitações representadas por uma instituição que se tornou exemplo de local específico e especializado de formação docente. A autora analisa, também, o papel da criação da Faculdade de Filosofia, Ciências e Letras da Universidade de São Paulo (FFCL-USP) e as consequências da incorporação da escola de professores do Instituo de Educação. A estrutura curricular do curso normal e suas dicotomias são minuciosamente tratadas no texto, com tabelas comparativas das disciplinas ministradas nos cursos normais em diferentes momentos da sua existência, revelando um movimento de idas e vindas nos processos que ora tendiam ao caráter propedêutico do curso ora a uma feição mais profissionalizante. A autora ratifica o posicionamento de que a LDB/ 61 não trouxe transformações significativas para a Escola Normal, demonstrando que tais modificações se deram no contexto de influência do Acordo MEC-USAID. Enfatiza que nesse período as ideias referenciais pautavam-se na teoria do capital humano. No interior dos embates políticos e ideológicos do período, a Escola Normal sofreu fortes críticas, o que abriu as portas para sua extinção.

Ajustes político-econômico e reforma educacional: a reforma de professores em foco analisa os rumos da formação inicial de professores desde a extinção da Escola Normal até a criação do CEFAM, situando nesse percurso a criação das chamadas Habilitações Especificas para o Magistério (HEM). Somente nos anos 80, 
FORMACCAO INICLAL DE PROFESSORES: DA ESCOLA NORMAL AO INSTTTUTO SU-PERIOR DE EDUCAÇÃO - UMA ABORDAGEM HISTÓRICA, DE LUCILENE PISANESCHI

com a necessidade de redefinição dos rumos de formação docente, o projeto CEFAM se firma, num momento importante para o país, com a abertura política e a retomada da democracia dando novo rumo às propostas educacionais para o país.

Os CEFAM's: Novos rumos para a formação inicial docente reflete uma densa e valorosa reflexão a partir do levantamento de dados de todas as unidades criados no estado de São Paulo e uma profunda discussão acerca das políticas que neles foram implantadas, em especial no que diz respeito ao seu ineditismo e à sua importância na recuperação da identidade das instituições de formação de professores no país. O CEFAM, segundo a autora, contribuiu para que novas abordagens fossem estabelecidas no campo educacional; no entanto, diante dos embates político-ideológicos do período, o que se verificou foi a permanência de um modelo dual de formação que colocou em evidência as contradições entre os cursos da HEM e as propostas dos Centros de Formação. O que se buscava era a superação das fragilidades curriculares e a ausência de um lugar voltado para o preparo profissional de professores. O fato de a legislação federal de 1990 ter situado a formação dos professores primários no âmbito do ensino superior, somado às condições políticas do estado de São Paulo naquele momento levaram à extinção dos CEFAM.

A formação dos professores das séries iniciais no âmbito do ensino superior, tema da Unidade II do livro, possui também quatro capítulos. Neles, a autora analisa a trajetória da formação inicial docente na educação superior destacando as disputas travadas no campo educacional brasileiro em torno dos cursos de Pedagogia e Normal Superior. Nessa unidade também são tratados os embates entre os endereços institucionais responsáveis pela formação dos professores das séries iniciais: as faculdades de educação e o então criado Instituto Superior de Educação.

Encontros e desencontros: as primeiras tentativas de constituir uma Escola Superior de Formação de Professores constitui um retrato histórico do surgimento 
do curso de Pedagogia no Brasil que nos ajuda a compreender seu surgimento, indicando e analisando as fragilidades que apresentava ao assumir uma função para a qual não foi criado, finalizando com o debate das consequências desse cenário para a formação docente. Em meio às contradições apresentadas pelo curso de Pedagogia, a autora foca a conjuntura política que levou à criação, em 1931, do Estatuto das Universidades Brasileiras, que dispôs sobre a organização do modelo universitário. Perante essas reformas, a universidade toma seu viés técnico e cientifico. Para compor sua discussão, a autora dialoga no texto com alguns teóricos como Sucupira (1969), Cury (1978) e Cacete (2002), para fundamentar a discussão sobre o processo de criação, implantação e implementação dos cursos de Pedagogia como momento da formação inicial de professores. A autora retoma os meandros que levaram à proposta de criação da Universidade do Distrito Federal, modelo esse que, partindo das influências de Anísio Teixeira, tinha na escola de formação de professores o “coração da universidade" (p.181), mas que não conseguiu sobreviver aos tórridos embates políticos da época. Pisaneschi finaliza o capitulo abordando o processo de extinção do UDF, premida pelas disposições do projeto de Gustavo Capanema que terminou por excluir as chances de criar um lugar institucional de formação profissional docente no ensino superior, fragilizando, dessa forma, o curso de Pedagogia.

Em $O$ curso de pedagogia e a formação de professores: dilemas e perspectivas, a autora esclarece que o curso de Pedagogia não foi criado com o desígnio de preparar o professor para a docência, mas acabou assumindo essa função por força das descontinuidades das políticas públicas na área e da incapacidade governamental de construir um projeto especificamente voltado a abarcar tal formação. Ao analisar todo o percurso do curso de Pedagogia a autora destaca os avanços e recuos nas políticas para o setor e suas consequências para a formação inicial dos professores primários. 
FORMACCAOO INICLAL DE PROFESSORES: DA ESCOLA NORMAL AO INSTTTUTO SU-PERIOR DE EDUCAÇÃO - UMA ABORDAGEM HISTÓRICA, DE LUCILENE PISANESCHI

A reconfiguração do campo educacional brasileiro nos marcos da nova Lei de Diretrizes e bases da Educação Nacional é o título A autora faz um " mapeamento" da realidade brasileira educacional brasileira que revelaram fragilidade do contexto educacional na esfera da educação básica. Colocando a proposta de repensar a forma como o nosso sistema estava firmado, primeiro a necessidade rever o currículo da educação básica e as definições de ensino e aprendizagem; segundo, a revisão das bases a partir dos quais os modelos de formação dos professores têm sido estabelecidos. Nesse contexto, a autora apresenta o Instituto Superior de Educação pensado como uma tentativa de criação de um locus institucional voltado para a formação profissional docente. Pisaneschi faz uma análise da proposta de criação dos Institutos e destaca a confusão que foi feita entre esses Institutos e o Curso Normal Superior, distinguindo em sua investigação as questões de ordem institucional das questões curriculares.

A parte empírica do estudo de Pisaneschi desenvolve-se no capítulo intitulado Dos limites às possiblidades: o Instituto Superior de Educação no interior das disputas do campo educacional brasileiro. Nele, a autora evidencia o seu objeto de estudo. Para ela, o Instituto Superior de Educação, desde sua implantação, enfrentou muitos momentos de fragilidade e não aceitação, especialmente em razão das disputas políticas travadas no interior do campo educacional brasileiro.

A pesquisa apresentada no livro foi extensa e profunda. A obra apresentou um mapeamento da distribuição territorial dos Institutos Superiores de Educação no Brasil e na América Latina apresentando todas as licenciaturas oferecidas pelos ISES. A pesquisadora fez um levantamento dos institutos públicos e privados, analisando a presença e a ausência desses ambientes nas diferentes regiões do país e levanta a problemática da ausência da criação de um ISE público no estado de São 
Paulo e as consequências dessa opção do poder público paulista diante da não consolidação dos institutos no território brasileiro, tal como previa a legislação federal.

Ao finalizar sua pesquisa, orientada pela análise dos modelos institucionais em curso, Pisaneschi argumenta que as instituições são "detentoras de valores, concepções e cultura [...]" (p.347), concluindo com a assertiva de que "as instituições formativas responsáveis pelo preparo inicial dos professores da educação básica devem possuir uma identidade institucional própria que contemple, no processo de organização dos seus cursos, a especificidade de uma formação de natureza profissional." (p.351)

É assim que essa obra constitui um estudo histórico-crítico e empírico da formação inicial do professor no Brasil que se caracteriza pela presença forte da dimensão política em toda a construção da pesquisa. Por isso, merece leitura de todos os interessados no tema da formação de professores. 


\section{Instruções para os}

autores

\section{Instrutions for authors}




\section{SubMISSÃo DE TRABALHOS, ASPECTOS ÉTICOS E DIREITOS AUTORAIS}

\section{Diretrizes para Autores}

\section{SUBMISSÃO DE TRABALHOS, ASPECTOS ÉTICOS E DIREITOS AUTORAIS}

Tendo em vista a publicação os autores podem submeter a análise da Comissão Editorial da revista Cadernos de Pós-graduação, artigos e resenhas em português, inglês, espanhol, francês e italiano. As resenhas devem corresponder a obras recentes de, no máximo, dois anos do ano de sua publicação.

Os trabalhos submetidos à Comissão Editorial serão avaliados em relação ao mérito científico, adequação às orientações da Associação Brasileira de Normas Técnicas (ABNT) às instruções editoriais contidas neste documento.

Os textos enviados deverão ser originais e inéditos e que não seja simultaneamente postulado em outras revistas ou órgãos editoriais. Textos já veiculados em eventos científicos realizados fora do país não poderão ultrapassar um ano de sua divulgação e devem ter essa data explicitada. A Comissão Editorial não aceitará artigos ou resenhas submetidos simultaneamente a outras publicações, nacionais ou estrangeiras.

Os autores devem submeter o texto à revisão ortográfica, gramatical e normativa antes de apresentá-lo à Revista.

Todos os artigos submetidos a revista passam pela verificação do programa CopySpider (software detector de plágio).

Se a pesquisa que deu origem ao artigo envolver seres humanos, é recomendável declarar que as abordagens e os instrumentos metodológicos utilizados obedeceram aos procedimentos éticos estabelecidos para a pesquisa científica em Ciências Humanas.

À Comissão Editorial reserva-se o direito de aceitar ou não os trabalhos a ela enviados e, eventualmente, sugerir modificações ao(s) autor(es), a fim de adequar os textos à publicação.

Os artigos devem conter, no máximo, 3 (três) autores. A autoria deve ser limitada a aqueles que fizeram uma contribuição significativa para a concepção, projeto,

Cadernos de Pós-graduação, São Paulo, v. 17, n. 2, p. 284-288, jul./dez. 2018. 
execução ou interpretação do estudo relatado. Todos aqueles que fizeram contribuições significativas devem ser listados como coautores. O autor deve se assegurar que todos os coautores adequados e nenhum inadequado estão incluídos no artigo, e que todos os coautores viram e aprovaram a versão final do documento e concordaram em sua apresentação para publicação.

Todos os autores precisam ser identificados na plataforma de submissão online da Revista. Todos os campos do perfil dos autores devem ser preenchidos, tais como: nome, instituição de vínculo, país e resumo da biografia (grau acadêmico, instituição, área de atuação, departamento).

Informar o número de Registro ORCID® (Open Researcher and Contributor ID) de todos os autores. Caso não possua, fazer o cadastro através do link: < https://orcid.org/register>. O registro é gratuito.

Para submeter artigo é necessário estar cadastrado como autor na plataforma virtual da revista: http://www4.uninove.br/ojs/index.php/cadernosdepos/login

Cada autor só poderá ter um manuscrito em tramitação, entre o início da submissão e a publicação final. Será observado um intervalo de dois anos entre a publicação de textos escritos pelo mesmo autor e o início de um novo processo de submissão.

Cadernos de Pós-graduação é destinada, prioritariamente, a publicação dos manuscritos dos estudantes da pós-graduação em educação, mas nada impede que os seus co-autores sejam mestres ou doutores.

O texto enviado não deve conter identificação do(s) autor(es). Para assegurar a integridade da avaliação por pares cega, para submissões à revista, deve-se tomar todos os cuidados possíveis para não revelar a identidade de autores e avaliadores entre os mesmos durante o processo.

Isto exige que autores, editores e avaliadores (passíveis de enviar documentos para o sistema, como parte do processo de avaliação) tomem algumas precauções com o texto e as propriedades do documento:

Os autores do documento devem excluir do texto qualquer referencia a autoria.

Em documentos do Microsoft Office, a identificação do autor deve ser removida das propriedades do documento (no menu Arquivo $>$ Propriedades), iniciando em Ar- 


\section{Cadernos}

quivo, no menu principal, e clicando na sequência: Arquivo $>$ Salvar como... $>$ Ferramentas (ou Opções no Mac) > Opções de segurança... > Remover informações pessoais do arquivo ao salvar $>\mathrm{OK}>$ Salvar.

Os trabalhos enviados devem vir acompanhados, em arquivo separado, de formulário de autorização (conforme modelo disponível na página virtual do periódico) sobre a exclusividade de publicação do artigo pela revista Cadernos de pós-graduação, e pela cedência de direitos do autor.

A instituição e/ou quaisquer dos organismos editoriais desta publicação não se responsabilizam pelas opiniões, ideias e conceitos emitidos nos textos, sendo esses de inteira responsabilidade de seu(s) autor(es).

Todos os trabalhos serão submetidos à avaliação de, pelo menos, dois pareceristas, garantidos o sigilo e o anonimato tanto do(s) autor(es) quanto dos especialistas dos pareceres (blind peer review).

As sínteses dos pareceres, em caso de aceite condicionado ou recusa, serão encaminhadas ao(s) respectivos autor(es) via plataforma da revista.

O tempo médio entre a submissão do artigo e a publicação, mediado pelo processo de avaliação é de, aproximadamente, 6 meses.

Os trabalhos devem ser submetidos exclusivamente por meio da plataforma disponível no endereço eletrônico da revista Cadernos de pós-graduação.

\section{NORMAS BÁSICAS DE FORMATAÇÃO}

Os textos devem ser elaborados conforme as instruções a seguir:

1) Digitados no Editor Word (.doc); fonte Times New Roman; tamanho 12; alinhamento à esquerda; espaçamento 1,5 .

2) Os artigos devem ter entre 14 mil e 35 mil toques (considerados caracteres e espaços), e as resenhas, entre 3,5 mil e 7 mil toques (considerados caracteres e espaços).

Cadernos de Pós-graduação, São Paulo, v. 17, n. 2, p. 284-288, jul./dez. 2018. 
3) Os artigos devem apresentar obrigatóriamente os seguintes quesitos (nesta ordem):

a) título (diferenciar maiúscula/minúscula);

b) title: Título do artigo em língua inglesa;

c) resumo (entre cem e 150 palavras); Os resumos deverão ter os principais indicadores do desenvolvimento do artigo. Obrigatoriamente, deverão conter o objeto de pesquisa, a questão de pesquisa, o modelo teórico utilizado como fundamentação, a abordagem metodológica, as categorias fundamentais e algumas das conclusões do estudo realizado, seja de caráter empírico ou meramente teórico.

d) Palavras-chave (máximo cinco, separadas e finalizadas por ponto, inicia com letra maiúscula)

e) Abstract: versão do resumo, em inglês;

f) Key-words: versão das palavras-chave, em inglês;

g) Ao final, obrigatoriamente, devem ser registradas as referências de todos os autores citados no texto, apenas eles, com as informações completas. A revista adota o sistema autor-data. O recurso tipográfico utilizado para destacar o título deverá ser itálico (dúvidas consultar ABNT NBR 10520 e 6023 respectivamente).

h) Nos Indicativo de seção os números são separados por 1 (um) espaço em branco

4) As notas explicativas (não usar nota de rodapé), devem vir ao final do texto (antes de referências), com numeração sequencial em algarismos arábicos.

5) As unidades de medidas devem seguir os padrões do Sistema Internacional de Unidades (SI), elaborado pelo Bureau Internacional de Pesos e Medidas (BIPM) [www.bipm.org]. Em casos excepcionais, a unidade adotada deve ser seguida da unidade expressa no SI, entre parênteses.

6) As palavras estrangeiras devem ser grafadas em itálico e os neologismos ou acepções incomuns, em fonte normal e entre "aspas". 
7) Os trabalhos que exijam publicação de gráficos, quadros, tabelas ou quaisquer tipos de ilustração devem apresentar as respectivas legendas, incluindo a fonte completa e sua posição no texto. Os arquivos devem ser inseridos no corpo do texto e encaminhados separadamente e, sempre que possível, no formato original do programa de elaboração (por exemplo: CAD, CDR, EPS, JPG, TIF, XLS). As imagens devem ter alta definição (mínimo de 300 dots per inchs [DPIs]). Mapas ou micrografias devem ser representados com as respectivas marcas de escala.

Identificação das ilustrações (figuras, gráficos, quadros, imagens ) - ABNT NBR 6022:2002 - Informação e documentação - Artigo em publicação periódica científica impressa - Apresentação - item 6.9

a.São indicados na parte inferior

b.exceção das tabelas que seguem IBGE

8) Sempre que envolve imagens nas publicações da Universidade Nove de Julho é necessário autorização: do fotografado e do fotógrafo. Foto com menor tem que ter autorização dos pais também. Para requerer os formulários nos envie um e-mail.

\section{NORMAS PARA CITAÇÕES E REFERÊNCIAS}

As normas para citações nos textos a serem publicados na Revista Cadernos de Pós-graduação deverão seguir as determinações da Associação Brasileira de Normas Técnicas (ABNT).

Referencias - ABNT NBR 6023:2002 - Informação e documentação - Referências - Elaboração - item 6.3

a. Alinhadas à esquerda, espaço simples

Para acesso consultar as normas na página da Biblioteca http://docs.uninove.br/arte/pdfs/manual-elaboracao-Trabahos-ABNT.pdf 